Alaska Division of Geological \& Geophysical Surveys

MISCELLANEOUS PUBLICATION 140

\title{
RARE EARTHS IN ALASKA-PROCEEDINGS OF OFFICE OF THE GOVERNOR'S ALASKA SCIENCE AND ENGINEERING ADVISORY COMMISSION SYMPOSIUM, HELD AUG. 17-18, 1988, IN FAIRBANKS, ALASKA
}

Compiled by

Henry Cole

May 2011

\author{
Released by \\ STATE OF ALASKA \\ DEPARTMENT OF NATURAL RESOURCES \\ Division of Geological \& Geophysical Surveys \\ 3354 College Rd. \\ Fairbanks, Alaska 99709-3707
}

$\$ 14.00$

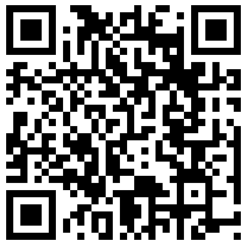





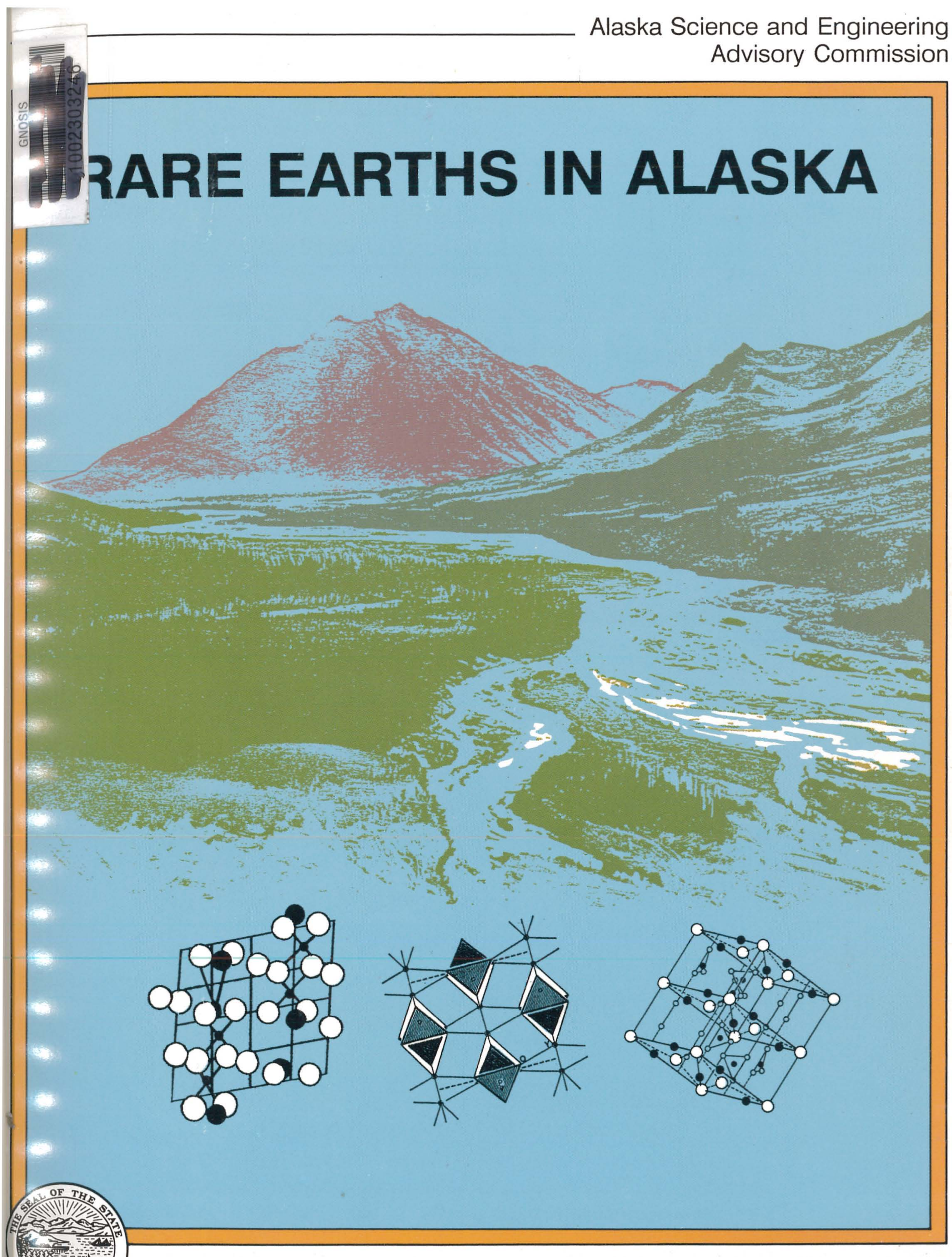


Alaska Science and Engineering

Advisory Commission

\title{
RARE EARTHS IN ALASKA
}

\author{
Proceedings of a Symposium \\ August 17 and 18, 1988 \\ Fairbanks, Alaska
}

Office of the Governor

Juneau, Alaska

1990

ALASKA

QE

390.2

R37

Commission, Office of the Governor, produced at a cost of $\$ 35.65$ per copy.

This publication was printed in Fairbanks, Alaska, and is for general distribution to interested state and federal agencies, educational institutes, libraries, and the private sector.

R37

1990 


\section{Dr. John T. Dillon \\ 1947-1987 \\ Geologist \\ Alaska Division of Geological and Geophysical Surveys}

This volume is dedicated to the memory of Dr. John T. Dillon who died in a plane crash in the Brooks Range while returning from the summer field season, August, 1987.

John was a superb geologist who worked in and loved Alaska since 1977. He was a close friend and professional colleague of many attending this symposium, and would have eagerly contributed to this effort.

In commemoration Dillon Mountain on the Dalton Highway was named for him. He is survived by his wife Mary Moorman and his three children Steven Noah, Paneka, and Abraham. 


\section{Preface and Acknowledgements}

In 1987 the threat of declining state oil revenues and Governor Cowper's desire for economic diversification of Alaska led to an examination of state options for technological development. That same year technological breakthroughs of new superconductivity materials occurred. Realistically we knew that Alaska did not have the necessary technical base for exotic research, but development of a related support industry such as mining or processing of superconducting source minerals seemed possible and even economical. Scientists from Mitsubishi Research Institute and Mitsubishi Materials Corporation convinced us to convene this symposium to explore options in developing a rare-earth industry in Alaska. Consequently, on August 17-18, 1988 at the Geophysical Institute, University of Alaska Fairbanks, a symposium was held discussing basic rare-earth technical facts and mineral potential in Alaska.

We are deeply grateful for advice on technical planning and choice of speakers received from a group of nationally known physicists and chemists. Dr. Marty Blume, Deputy Director of Brookhaven National Laboratory, Brookhaven, Long Island, and Dr. Karl Gschneidner, Director of the Rare-Earth Institute, Iowa State University, Ames, Iowa, were crucial in suggesting the agenda and identifying the best people for presentations. Dr. Robert Forbes, Director of Alaska Division of Geological and Geophysical Surveys, and Mr. Jim Barker of the U.S. Bureau of Mines, Fairbanks, Alaska, provided help and advice on presentation problems of Alaska minerals and mining information.

The hospitality of the Geophysical Institute is gratefully remembered. Logistical organization of meetings was ably handled by the augmented staff of Conferences and Special Events in the Department of Continuing Education, University of Alaska Fairbanks. Many thanks go particularly to Nancy Bachner, David Marusek, Sharon Oien, Nancy Smoyer, Gary Walker, June Ward, and Colleen Wright for assistance during the symposium. Tape transcription was managed by Secretaries Unlimited of North Star Terminals, Fairbanks, and later transcription was rapidly managed by Lilla Giles of 150 Word Processing, Juneau. Final editing was done by Wanda Seamster and Amanda Irene Andrade of the Arctic Environmental Information and Data Center, University of Alaska Anchorage. Printing was done by Commercial Printing, Fairbanks. Bobbi Guthert, secretary to ASEAC, coordinated all details of editing and printing.

Funding for this meeting was shared by the Chancellor's Office of the University of Alaska Fairbanks, the Governor's Office of International Trade, and the Alaska Science and Engineering Advisory Commission.

All of these persons made the symposium and proceedings a success and deserve great thanks.

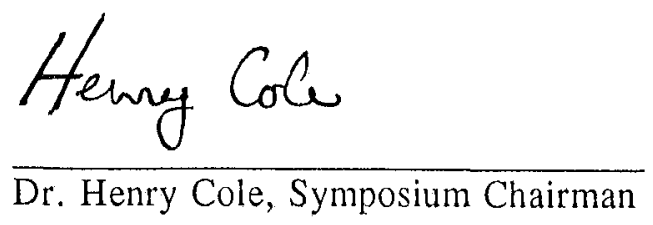




\title{
Alaska Science and Engineering Advisory Commission
}

\author{
Office of the Governor \\ P.O. Box AD \\ Juneau, AK 99811
}

The Alaska Science and Engineering Advisory Commission created by the legislature in 1986 investigates and prepares policy on Alaska science and engineering issues affecting economic development, the environment, health, and education.

\section{Commission Members}

Dr. Henry Cole, Chairman

OMB, Division of Policy

P.O. Box AM

Juneau, AK 99811-0164

Dr. Brian Allee

P.O. Box 3-2000

Juneau, AK 99802-2000

Clint Elston**

AlasCan International, Inc.

3400 International Way

Fairbanks, AK 99701

Dr. Aurora Hovland*

1890 Parkway Drive

Anchorage, AK 99504

Erwin Long

Arctic Foundations, Inc.

5621 Arctic Blvd.

Anchorage, AK 99518

Dr. Peter McRoy*

Institute of Marine Science

University of Alaska Fairbanks

Fairbanks, AK 99775-1080
Dr. William Mills

1544 Hidden Lane

Anchorage, AK 99501

Dr. Paul Reichardt

College of Natural Sciences

University of Alaska Fairbanks

465 Duckering Building

Fairbanks, AK 99775-1240

Dr. William Sackinger**

Geophysical Institute

University of Alaska Fairbanks

Fairbanks, AK 99775-0800

Dr. John Sibert

Executive Director

Alaska Science and Technology Foundation 550 West 7th Avenue, Suite 360

Anchorage, AK 99501-3555

Donald E. Pickering, M.D.***

1200 Airport Heights Drive

Anchorage, AK 99508

* Commission expired November 1990

** Appointed November 1990

***Commission expired August 1989 


\section{Executive Summary and Recommendations}

"Rare Earths in Alaska" was a conference held in Fairbanks in August 1988 to examine the economics of development of a rare-earth industry in Alaska. The meeting discussed a description of rare earths and their uses, ore location in Alaska, mining possibilities, extraction and purification, and worldwide market demand. The invited participants represented all technical and political groups required to comprehensively address the issue. This included Alaska's Division of Geological and Geophysical Surveys and Division of Mining; U.S. Geological Survey; U.S. Bureau of Mines; the University of Alaska; Alaska Pacific University; recognized international industrial suppliers of rare earths such as Molycorp and Mitsubishi Research Institute; Alaska miners; mining and extraction engineers; geologists; and consultants from outside Alaska. The meeting posed two questions: Is it viable to try to develop this industry in Alaska at this time? What recommendations should be made in light of the resources definitely known to exist in Alaska?

The rare-earth elements, usually considered to include scandium, yttrium, and the lanthanides, are a group of fifteen metals with rather similar properties. Although rare-earth elements are found throughout the world, rare-earth deposits have been commercially developed at only a few sites, primarily in California, China, Australia, and Brazil.

The main commercially known ores are bastnaesite (a carbonate), and monazite and xenotime which are phosphates. They occur in placer deposits and beach sand and in igneous forms along with titanium, tin, uranium and thorium, and other elements. Materials from these mines are processed in the U.S., Europe, and Japan, and ultimately find their commercial use in products such as alloys for steel, chemicals, petroleum catalysts, additives in glass and ceramics, optical enhancement, color phosphors for television screens, or in electronic components. Yttrium achieved recent notoriety for its use in high-temperature superconducting materials. Neodymium is essential for high-strength magnets.

Several features of the rare-earth industry make it rather unique. The rare-earth deposits, without exception, consist of mixtures of most rare-earth elements. Because of their chemical similarities, the tedious and costly purification and separation of any one rare-earth metal from the ore produces other purified rare-earth metals as by-products. Commercial grades of rare-earth products include ore concentrates, mixed metals, compounds, pure oxides, and pure metals. Thus industry must market all fifteen rare-earth elements, even though some are inherently more valuable and profitable than others. Furthermore, the total market for rare earths (approximately 50,000 metric tons of rare metal oxide ore in 1985) is small, and demand for specific metals is volatile. These factors have created an industry dominated by just a few international corporations which produce most rare-earth ore as a by-product of other mining.

To date, Alaska has not been involved in the rare-earth industry in any way. However, the state is a large potential supplier of all rare earths. Based on the limited mineral survey work conducted to date, approximately one dozen Alaska sites in the southeast and interior portions of the state are known to have potential as commercial rare-earth deposits.

Alaska deposits occur in four main areas: 1) placer and beach sands in the areas near Old Crow; 2) placer sands and intrusions in the Darby Mountains, Selawik, Purcell Mountains, and Death 
Valley; 3) the Yukon/Tanana terrane of the Steese-White Mountain and Healy-Dexter Creek areas; and 4) the carbonatite deposits at Bokan Mountain, Prince of Wales Island and Salmon Bay in southeastern Alaska. Bokan Mountain in southeast Alaska is the best example studied (with estimated reserves of 40 million tons of ore containing 0.5 to 1.0 percent rare earths), and has generated interest among corporations dealing in rare earths (although there has yet been no move toward development).

Generally, the known Alaska deposits seem to have higher concentrations of heavier rare-earth elements such as yttrium than do most present commercial ores. This is an advantage; there is little competition from producers in the lower United States. At the same time there is a disadvantage since the relative lack of these heavy elements from commercial ores has retarded the development of methods for isolating and purifying them. Also, the industry has not been prompted to invent many commercial uses for them.

\section{Recommendations}

1. The State should maintain a modest effort to assemble information necessary for industry to evaluate the possibility of development extraction and refinement at given sites. At the Commission's August 17-18, 1988, meeting in Fairbanks, the consensus was that development of a rare-earth industry in Alaska would take many years.

2. The Alaska Division of Geological and Geophysical Surveys and its Division of Mining, together with federal agencies, should continue exploration of the extent and characteristics of Alaska's rare-earth resources:

(a) by using field data from known placer deposits;

(b) by analyzing the existing National Uranium Resource Evaluation (NURE) geochemical data set for potential rare-earth deposits; and

(c) by combining geologic survey data and NURE data with satellite-based remote sensing techniques for mineral surveying (such as Landsat and the University of Alaska's Synthetic Aperture Radar facility, operating in visible, infrared, and radar modes).

The most likely prospects for further characterization are Bokan Mountain, Prince of Wales Island, and the most likely of the interior placer sites.

3. The Mineral Industry Research Laboratory and the Department of Mining Engineering at the University of Alaska should be encouraged to develop capabilities for:

(a) performing analytic techniques for assaying and refining;

(b) conducting extraction and purification tests and pilot programs tailored to Alaska deposits;

(c) providing analysis of existing sites (e.g., Bokan Mountain, and certain promising sites in Alaska's interior regions), and new sites as they are identified; and

(d) developing methods for keeping radioactivity levels in wastes from rare-earth activities below the federal Environmental Protection Agency's definition of "low" level hazards. 
4. Land ownership and legal status of promising deposits should be firmly determined.

5. Exchange programs with key outside laboratories such as the Rare-Earth Information Center at Iowa State University should be developed to supplement existing levels of expertise.

6. Alaska Pacific University and the Governor's Office of International Trade should develop a monitoring program for the monitoring for worldwide demand for strategic minerals.

7. Alaska should establish guidelines for an approved waste site in Alaska. 


\section{Contents}

xiii

$\mathrm{xV}$

xvi

1

1

3

15

19
Symposium Agenda

List of Acronyms

Periodic Table of the Elements

Day One

Dr. Henry Cole, Science Advisor to the Governor of Alaska

The Description and Physics of Rare Earths

Dr. Karl Gschneidner, Director, Rare-Earth Information Center

World Rare-Earth Resources and Their Problems

Dr. Masaharu Kamitani, Chief, Mineral Resources Section, Geological Survey of Japan

Industrial Uses and Future Demand for Rare Earths

Dr. Barry Kilbourn, Coordinator for Technical Development, Unocal/Molycorp

Uranium-Thorium Deposits as Pathfinders for Rare-Earth Element Exploration in Alaska

Dr. Robert B. Forbes, Alaska State Geologist; Director of Division of Geological and Geophysical Surveys, Alaska Department of Natural Resources

Rare-Earth Elements and Yttrium in Alaska

James C. Barker, U.S. Bureau of Mines

The Mt. Prindle Area Rare-Earth Deposit

Jeff Burton, Coordinator of Mining Technology Program, Bering Straits Native Corporation

Industrial Extraction and Purification Techniques for Rare Earths

Dr. R.G. Bautista, Professor, Mackay School of Mines, University of Nevada.

Land-Use Planning and Permitting

Mr. Gerald Gallagher, Director, Division of Mining, Alaska Department of Natural Resources

Day Two

Call to Order: Dr. Henry Cole

Break Out Sessions

Session Recommendations 
Final Summary and Close

69

Technical Presenters

71

Symposium Participants

xii 


\title{
Symposium Agenda
}

\author{
August $17 \& 18,1988$ \\ Main Auditorium, Room 214, Geophysical Institute \\ West Ridge, University of Alaska Fairbanks
}

\begin{abstract}
August $17 \quad 9: 00$ am $\quad$ Opening remarks and welcome
Dr. Henry Cole, Governor's Office, Alaska.

9:15 am The Description and Physics of Rare Earths

Dr. Karl Gschneidner, Iowa State University, Ames, Iowa.

10:15 am Coffee Break.

10:30 am World Rare-Earth Resources and their Problems

Dr. Masaharu Kamitani, Ministry of International Trade and Industry, Japan.

11:00 am Industrial Uses and Future Dernand for Rare Earths

Dr. Barry Kilbourn, Unocal/Molycorp, White Plains, New York

12 Noon Lunch: Globe Room.

1:00 pm Uranium and Thorium Deposits as Pathfinders for Rare-Earth Element Exploration in Alaska

Dr. Robert Forbes, State Geologist, Director, Division of Geological \& Geophysical Surveys, Alaska Department of Natural Resources, Fairbanks.

Rare-Earth Elements and Yttrium in Alaska

Mr. Jim Barker, Geologist, U.S. Bureau of Mines, Fairbanks.

The Mount Prindle Area Rare-Earth Deposit

Mr. Jeff Burton, School of Career and Continuing Education, University of Alaska Fairbanks (UAF).

3:00 pm Break.

3:15 pm Industrial Extraction and Purification Techniques for Rare Earths Dr. R.G. Bautista, Mackay School of Mines, University of Nevada, Reno, Nevada.

4:15 pm Land Use Planning and Permitting

Mr. Jerry Gallagher, Division of Mining, Alaska Department of Natural Resources, Anchorage.

5:30 pm Reception, Globe Room, Geophysical Institute, UAF.
\end{abstract}




\title{
Symposium Agenda (continued)
}

\author{
August $17 \& 18,1988$ \\ Main Auditorium, Room 214, Geophysical Institute \\ West Ridge, University of Alaska Fairbanks
}

\author{
August $18 \quad 9: 00$ am Introduction and Recapitulation of Wednesday's Presentations. \\ 9:30 am Start of Discussion Groups (in various rooms as assigned). \\ "Survey and Exploration Needs" \\ Dr. Bob Hoekzema, U.S. Bureau of Mines, Moderator. \\ "Extraction and Refining Methods, Beneficiation" \\ Dr. Don Cook, Mineral Industries Research Laboratory, UAF: \\ Moderator. \\ "Environmental Considerations" \\ Dr. Paul Reichardt, Department of Chemistry, UAF, Moderator. \\ "Pacific Rim Trade and Marketing" \\ Bob Poe, Office of International Trade, Moderator. \\ "Manufacturing in Alaska" \\ Dr. Marvin Andresen, Professor of Business Administration, UAF \\ Moderator. \\ 10:30 am Coffee Break. \\ 10:45 am Continue Discussion Groups. \\ 12 Noon Lunch: Globe Room. \\ 1:00 pm Report on Highlights of Discussion Groups by Moderators. \\ 1:30 pm Summary Session. \\ Panel Discussion of Presenters and Moderators. \\ 2:30 pm Adjournment.
}




\section{List of Acronyms}

ADEC

ASTF

ASEAC DGGS

DNR

DOE

DTPA

EDTA

EIS

EPA

GGG

HEDTA

HDEHP

HSSR

IUPAC

MIRL

MITI

NPDES

NURE

OIT

PLZT

ppm

RCRA

REE

RIC (REIC)

REO

TBP

$\mathrm{T}_{\mathrm{c}}$

tpy

UAF

USBM

USGS

YAG
Alaska Department of Environmental Conservation

Alaska Science and Technology Foundation

Alaska Science and Engineering Advisory Commission

Alaska Division of Geological and Geophysical Surveys

Alaska Department of Natural Resources

U.S. Department of Energy

Diethylenetriaminepenta-acetic acid

Ethylenediaminetetra-acetic acid

Environmental Impact Statement

Environmental Protection Agency

Gadolinium-gallium-garnet

Monoprotonated ethylenediaminetetra-acetic acid

Di-2-ethylhexylphosphoric acid

Hydrogeochemical and Stream Sediment Reconnaissance (a NURE Survey)

International Union of Pure and Applied Chemistry

Mineral Industry Research Laboratory, University of Alaska

Fairbanks

Ministry of International Trade and Industry (Japan)

National Pollutant Discharge Elimination System

National Uranium Resource Evaluation Program

Office of International Trade, Office of the Governor (Alaska)

An electronic material used to produce visual displays (e.g., computer terminals); it is made from lead, lanthanum, zirconium, and titanium.

Parts per million

Resource Conservation and Recovery Act

Rare-earth element(s)

Rare-Earth Information Center, Iowa State University, Ames, Iowa

Rare-earth oxide(s)

Tributylphosphate

Critical temperature

Tons per year

University of Alaska Fairbanks

U.S. Bureau of Mines

U.S. Geological Survey

Yttrium-aluminum-garnet (laser) 


\section{PERIODIC TABLE OF THE ELEMENTS}

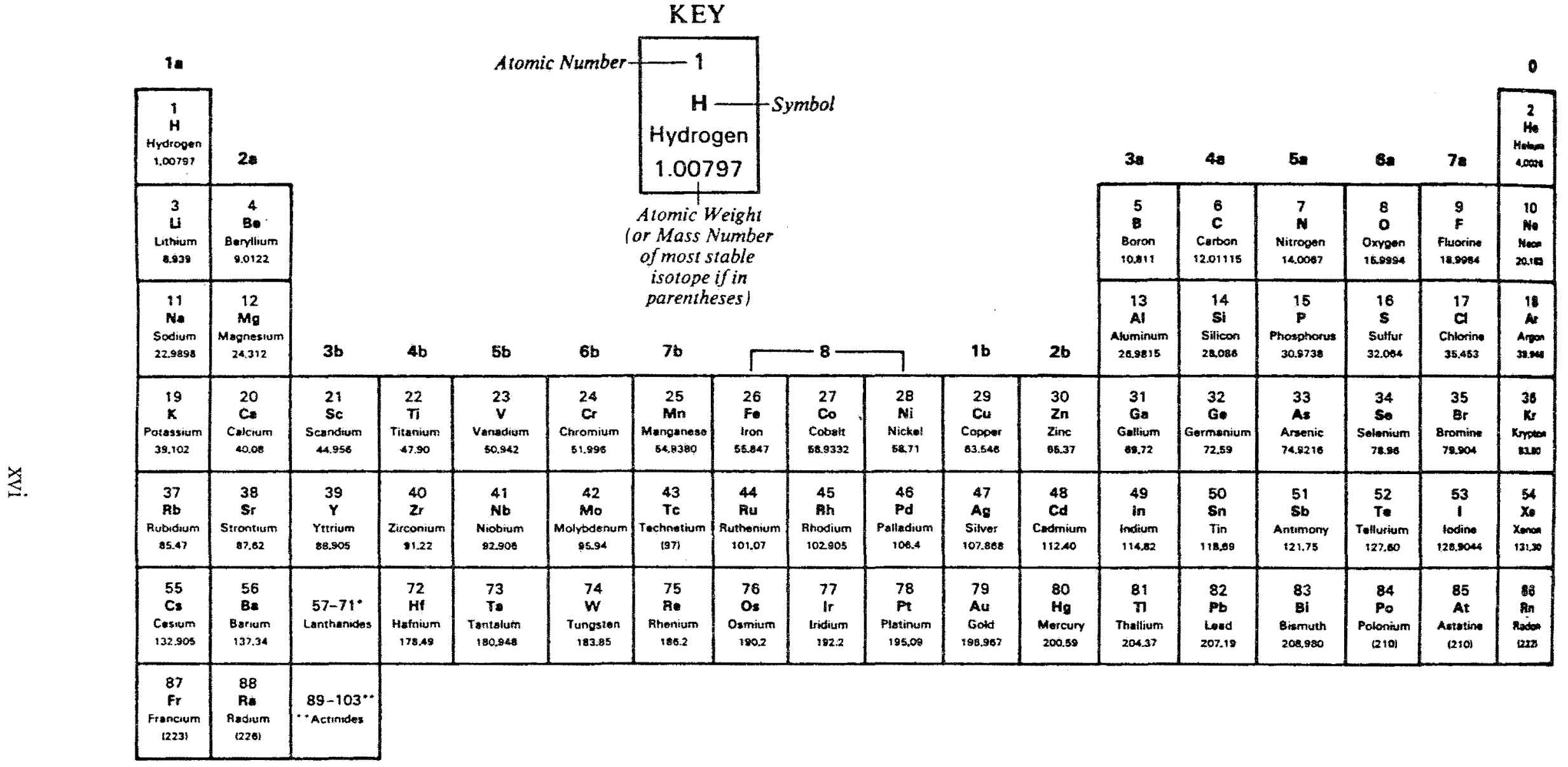

\begin{tabular}{|c|c|c|c|c|c|c|c|c|c|c|c|c|c|c|c|}
\hline - Lanthanides & $\begin{array}{c}57 \\
\text { Le } \\
\text { Larzthanum } \\
1 \times 2,91\end{array}$ & $\begin{array}{c}58 \\
\text { Ce } \\
\text { Cornum } \\
140.12\end{array}$ & $\begin{array}{c}59 \\
\mathrm{Pr} \\
\text { Praseodymium } \\
140.907\end{array}$ & $\begin{array}{c}60 \\
\text { No } \\
\text { Nocdyrminm } \\
144.24\end{array}$ & $\begin{array}{c}61 \\
\text { Pm } \\
\text { Promethum } \\
1145 !\end{array}$ & $\begin{array}{c}62 \\
\$ \mathrm{sm} \\
\text { Semwriumm } \\
160.38\end{array}$ & $\begin{array}{c}63 \\
\text { Eu } \\
\text { Europium } \\
78: 98\end{array}$ & $\begin{array}{c}84 \\
\text { Gd } \\
\text { Godolinium } \\
1 \$ 7.25\end{array}$ & $\begin{array}{c}65 \\
\text { Tb } \\
\text { Tarbium } \\
\text { is8,924 }\end{array}$ & $\begin{array}{c}66 \\
\text { DY } \\
\text { Dysprosium } \\
162.50\end{array}$ & $\begin{array}{c}67 \\
\text { Ho } \\
\text { Holmium } \\
184,930\end{array}$ & $\begin{array}{c}68 \\
\text { Er } \\
\text { Erbium } \\
187.25\end{array}$ & $\begin{array}{c}69 \\
\text { Thm } \\
\text { Thutium } \\
\text { ros.234. }\end{array}$ & $\begin{array}{c}70 \\
\text { Yb } \\
\text { Yrorbium } \\
173,06\end{array}$ & $\begin{array}{l}71 \\
\text { Lu } \\
\text { Luretium } \\
174.97\end{array}$ \\
\hline *Acrinides & $\begin{array}{c}89 \\
\text { Ac } \\
\text { Actrinum } \\
\text { a2n }\end{array}$ & $\begin{array}{l}90 \\
\text { Th } \\
\text { Thoxitum } \\
232.03 t\end{array}$ & $\begin{array}{c}91 \\
\text { Pa } \\
\text { Protectunium } \\
031\end{array}$ & $\begin{array}{c}92 \\
U \\
\text { Unanums } \\
238.03\end{array}$ & $\begin{array}{c}93 \\
\text { Np } \\
\text { Neptunium } \\
|23\rangle \mid\end{array}$ & $\begin{array}{c}94 \\
\mathrm{Pu} \\
\text { Piutonium } \\
(244)\end{array}$ & $\begin{array}{c}95 \\
\text { Am } \\
\text { Ammertium } \\
\text { [243) }\end{array}$ & $\begin{array}{c}96 \\
\mathrm{Cm} \\
\text { curum } \\
2471\end{array}$ & $\begin{array}{c}97 \\
\text { Bk } \\
\text { Borktium } \\
[2,4]\}\end{array}$ & $\begin{array}{c}98 \\
0 \\
\text { Cafifornium } \\
\text { (251) }\end{array}$ & $\begin{array}{c}99 \\
\text { Es } \\
\text { Ematrinium } \\
\text { (254) }\end{array}$ & $\begin{array}{c}100 \\
\text { Fm } \\
\text { Fermium } \\
{[257)}\end{array}$ & $\begin{array}{c}101 \\
\text { Md } \\
\text { Menowlovium } \\
\text { (250) }\end{array}$ & $\begin{array}{c}102 \\
\text { No } \\
\text { Notwelium } \\
\text { (25s) }\end{array}$ & $\begin{array}{c}103 \\
L w \\
L m w r e n c i u m \\
257\end{array}$ \\
\hline
\end{tabular}




\section{Rare Earths in Alaska}

\section{Day One}

\section{Dr. Henry Cole:}

Welcome to the first symposium on rare earths in Alaska. This symposium is designed to bring together some knowledgeable experts from inside and outside Alaska to exchange basic current information about rare earths, and to explore the potential for development of these natural resources in Alaska.

As most of you know, we have a history in Alaska of exploiting natural resources such as crude oil, timber, fish, and other minerals which basically are shipped out of the state with very little value added. Governor Cowper is adamant about reversing this trend. In the case of rare earths, this means developing refining techniques of extraction or processing, and capturing within Alaska more of the downstream operations associated with these mineral resources. If a market exists, benefits are considerable: diversification of the Alaska economy (particularly as we move away from the pure commodity); benefits of supply to trading partners on the Pacific Rim; Lower 48 and worldwide technology exchange; and benefits to local communities, miners, universities, and laboratories of Alaska.

But we cannot do it alone. Alaska has a small population base with a small scientific community. This base must be strengthened; we must provide training and necessary technical resources to make these benefits happen. We invite your help and participation in this enterprise.

Some of you in this room may be curious, Alaskans in particular, if this exercise relates to the Governor's Alaska Science and Technology Foundation (ASTF) which recently passed the last legislative session. Through this symposium we are engaged in the basic planning necessary for any scientific project. Such planning is a prerequisite to define scientific programs which could potentially seek funds from ASTF or federal funding sources.

Our broad audience for the next two days includes members of universities, industry and state agencies, and miners and owners of the resources, all of the people and interests necessary to make rare-earth mining and development happen in Alaska. With this diversity of interested Alaskans and Outside and dispassionate experts, we also hope to move beyond the polarities existing in various state resource development enterprises to understand the problems we face in this area.

This symposium has been sponsored by the Office of the Governor through the Alaska Science and Engineering Advisory Commission (ASEAC). I am Chairman of ASEAC; Dr. Paul Reichardt, who will chair one of the breakout sessions tomorrow, is also a member. The symposium is also supported by the Chancellor's Office of the University of Alaska Fairbanks (UAF) and the Office of International Trade (OIT). We are also greatly assisted by the Office of Conferences and Continuing Education, and thank Nancy Bachner, Nancy 
Smoyer, Sharon Oien, June Ward, Colleen Wright, Gary Walker, and David Marusek for their work.

Day One is basically a long tutorial session. Dr. Karl Gschneidner of the Rare-Earth Information Center at Iowa State University will present the basic description, physics, and chemistry of rare earths so we're all speaking the same language. We welcome Dr. Masaharu Kamitani from the Ministry of International Trade and Industry (MITI) in Japan to present the Japanese resource base and rare-earth needs. Dr. Barry Kilbourn, Unocal/Molycorp, will describe industrial uses and future demands. This afternoon state geologist Dr. Robert Forbes, Mr. Jim Barker of the U.S. Bureau of Mines (USBM). and Mr. Jeff Burton will describe Alaska rare-earth resources from their own field work and experience. The state and federal viewpoints are equally important because of multiple land ownership.

Having identified what Alaska's rare-earth resources may be, we then move to extraction and refining problems and techniques presented by Dr. R.G. Bautista. Jerry Gallagher from the Division of Mining, Alaska Department of Natural Resources (DNR) in Anchorage, will discuss mining laws, issues, and regulations.

Day One will therefore be a one-way information flow from podium to audience. Day Two presents the opportunity to arrange the topic a slightly different way: a series of Alaska moderators will lead various session groups in areas of a) further resource and exploration needs, b) extraction and beneficiation, c) environmental considerations, d) Pacific Rim trade and marketing, and e) manufacturing.

Our goal is to identify critical areas that need more data, time frames and schedules, and even the amount of money that might be needed in these areas. We want to raise questions such as the degree of state support needed to make some of these things happen.

Later on Day Two, the moderators will report results from each session group, and later we will meet again for a wrap-up session.

This is an outstanding group of people, not only in terms of general expertise and considerable knowledge of how rare-earth industry works, but also because of the representation of critical agencies in Alaska. I personally look forward to a successful exchange of information.

I will now give the podium over to our first speaker, Dr. Karl Gschneidner, Director of the Rare-Earth Information Center at Iowa State University. 


\title{
The Description and Physics of Rare Earths
}

\author{
Dr. Karl Gschneidner \\ Director, Rare Earth Information Center \\ Iowa State University, Ames, Iowa
}

\begin{abstract}
Editors' Note: The text of the author's taped address was edited from a copy transcribed outside these offices. Editors assume ao responsibility for errors or omissions in transcription and have relied on the assistance and advice of the anthors and technical experts for technical corrections.
\end{abstract}

It certainly is a pleasure to be here, and I appreciate the invitation to speak about one of my favorite topics.

\section{Rare Earths as a Group}

There are basic properties of rare earths that are suitable for various applications. A descriptive background on rare-earth properties may assist in explaining how some of these are important to you. Figure 1 is the periodic table. The rare-earth elements (also called lanthanides) are those shown protruding below the table. Scandium and yttrium (shaded) are included with the lanthanide series of elements [lanthanum (atomic number 57) through lutetium (atomic number 71)]. Figure 2 defines rare earths according to the International Union of Pure and Applied Chemistry (IUPAC), Be aware that many people include only the lanthanides, excluding yttrium, when talking about rare earths; I include scandium and yttrium.

The lanthanides themselves are divided into two groups. The light lanthanides (lanthanum through europium) comprise the first half of the series; the heavy lanthanides include gadolinium through lutetium. This terminology has been used for more than fifty years. We exclude promethium; it is radioactive with a half-life of 13 years and does not exist in a stable state in nature. I'm still including scandium although its geochemistry and chemistry are different in certain respects from the rest of the group.

The rare-earth industry (Figure 3) is worldwide. Other industries, such as the steel industry, basically deal with one element, iron or copper, for example. But there are 16 different rareearth elements with very complex properties which create the diverse and unique nature of the rare-earth industry.

There are several ways of dealing with rare-earth elements, their oxides, and their ores. First we have the naturally occurring mixtures which have the most prevalent usage by volume. Silicates and nonmetals are usually separated from naturally occurring elements leaving a mixture known as mischmetal. It is perhaps more accurately called mischmetal oxide (mixed rare earths in oxide form) which is how it normally occurs in nature.

Next we have cerium-rich mixtures in which the lanthanum, yttrium, and some of the other light lanthanides have been removed or, alternatively, we may produce a cerium-free mixture which is used in industry. We have a special selection called didymium oxide which is a praseodymium-neodymium mixture. Glassblower's goggles, dark blue safety goggles, are composed of a didymium glass. This praseodymium-neodymium mixture absorbs the strong sodium $d$-line light. It's one of the oldest uses, and there are other mixtures also employed 
in this manner. You can buy mixtures of primarily these two elements from Molycorp and probably some Japanese companies.

\section{The Importance of Purity}

The various purities required in different rare-earth mixtures also makes it difficult to characterize them. The pure metals range from $90 \%$ to $99 \%$, and may have to be up to 99.999\% pure for optical uses. The use will govern percent purity. For example, permanent magnets probably only require $95 \%$ purity. Magnetic properties of a samarium-cobalt magnet or a neodymium-cobalt magnet will not be changed significantly if it contains another $5 \%$ of other assorted rare earths. Such an unnecessary degree of purity would also be more costly. Conversely, $99.999 \%$ pure europium is required when combined with the yttrium host for the europium dopant which gives TV its red color. If the europium is not of a high purity, the other rare earths present as impurities will cause an aberration in color because of the various additional excitations in the electron levels. Usage governs everything.

\section{Basic Applications of Rare Earths}

Some basic uses of the lanthanide series, yttrium, and scandium are noted in Figure 4. High-purity materials of $99 \%$ or better are used to control the index of refraction in camera lenses. Phosphors can be composed of europium, gadolinium, or scandium, with yttrium as a host material in TV tubes. Laser materials use neodymium oxide. High purity is necessary for yttrium-aluminum-garnet (YAG) lasers in optical applications and for arc lamps using scandium.

Applications of pure rare earths (Figures 5 and 6) include decolorizing of glass (cerium); glass polishing and catalysts (cerium); and permanent magnets (neodymium, samarium, or dysprosium). Some garnet (gadolinium) uses must have very high purities. Magnetostrictive delay lines use terbium and dysprosium. Mixed rare earths which need no separation prior to their application are used for lighter flints, alloying agents, catalytic converters for ' automobiles, and cracking catalysts for gasoline. More than $50 \%$ of current expenditure on rare earths is linked to the high-purity uses. The cost is incurred in separating elements and refining them for higher purity. However, people are willing to pay because rare earths have unique properties.

Gadolinium is the only rare earth with a major application in nuclear energy (Figure 5). It is used for control rods because of its nuclear properties, namely a large collision crosssection for neutrons. Other applications of rare-earth elements include oxygen sensors for stabilized zirconia electrodes, stabilizing zirconium oxide, ceramics for uses other than oxygen sensors, silicon nitride ceramics, condensers, and neodymium doping for temperature compensation of barium titanate capacitors. There is a lot of work currently under way in doping ceramics with rare earths to give them various special properties. High-temperature superconductors now use rare-earth elements such as yttrium to a small extent, but there is a lot of competition from other high critical temperature $\left(T_{c}\right)$ superconducting materials that may impact the future market for rare earths.

Glass with a high index of refraction is produced using primarily lanthanum, along with ytterbium and gadolinium. Cerium gives glass a dark red color; praseodymium tends to give 


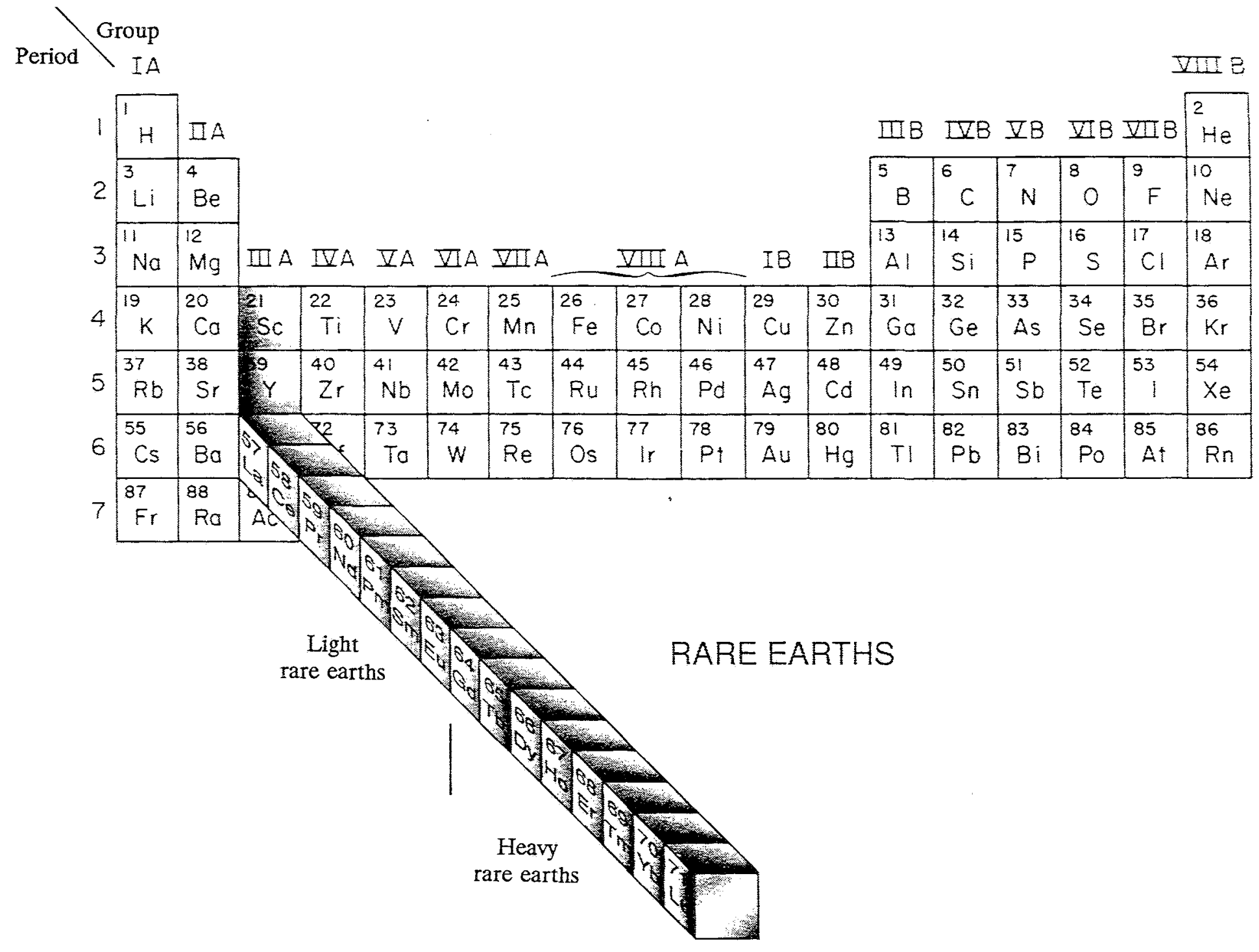

Figure 1. Periodic chart highlighting rare earths. 


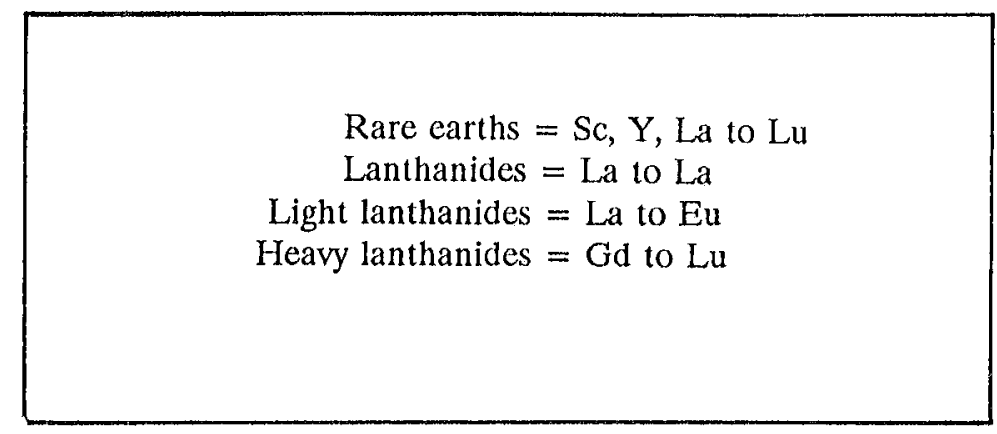

Figure 2. Definitions

Complex

Diverse

Hard to get a handle on

Worldwide

WHY:

16 different elements

Pm excluded - radioactive (half-life 13 years)

Several different combinations thereof

Natural occurring mixture

(metallic form caled misch metal)

Ce-rich mixture

Ce-free mixture

Didymium $(\mathrm{Pr} / \mathrm{Nd})$

Range of purities

90 to 95 to 99 to $99.99+$

Uses vary widely

Basic (i.e. steels) to high technology (optics)

Figure 3. The rare-carth industry. 
PHOSPHORS*
ARC LAMPS*

MIXED

CRACKING CATALYST

CATALYTIC CONVERTER

PHOSPHORS*
STABHIZED Z $\mathrm{ZO}_{2}$

ALLOYING AGENTS (MISCHMETAL)

FUNTS

\begin{tabular}{|l|l|l|l|l|l|l|l|l|l|l|l|l|l|l|}
\hline La & Ce & Pr & Nd & Oro & Sm & Eu & Gd & Tb & Dy & Ho & Er & Tm & Yb & Lu \\
\hline
\end{tabular}

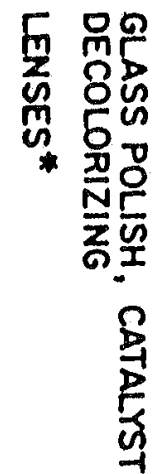

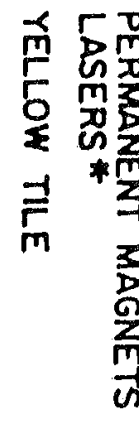

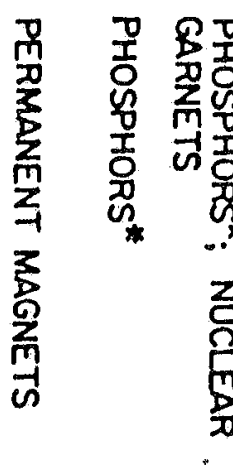

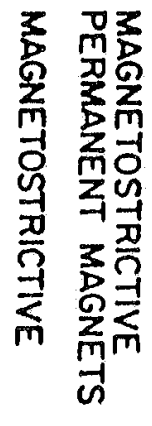

*PURITIES $\geq 99.9$

Figure 4. Industrial uses of rare carths. 


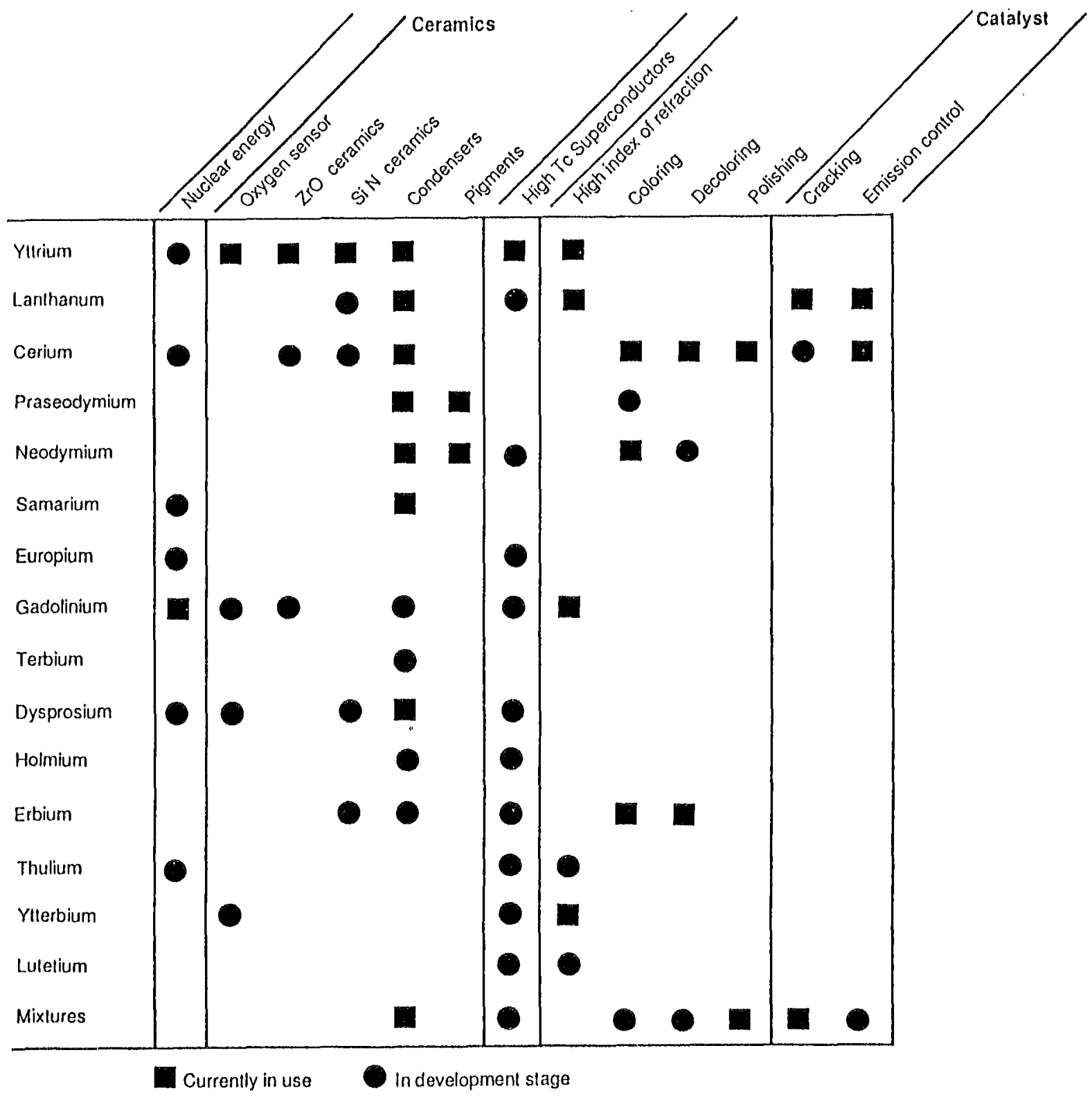

Figure 5. Applications of rare earths. 


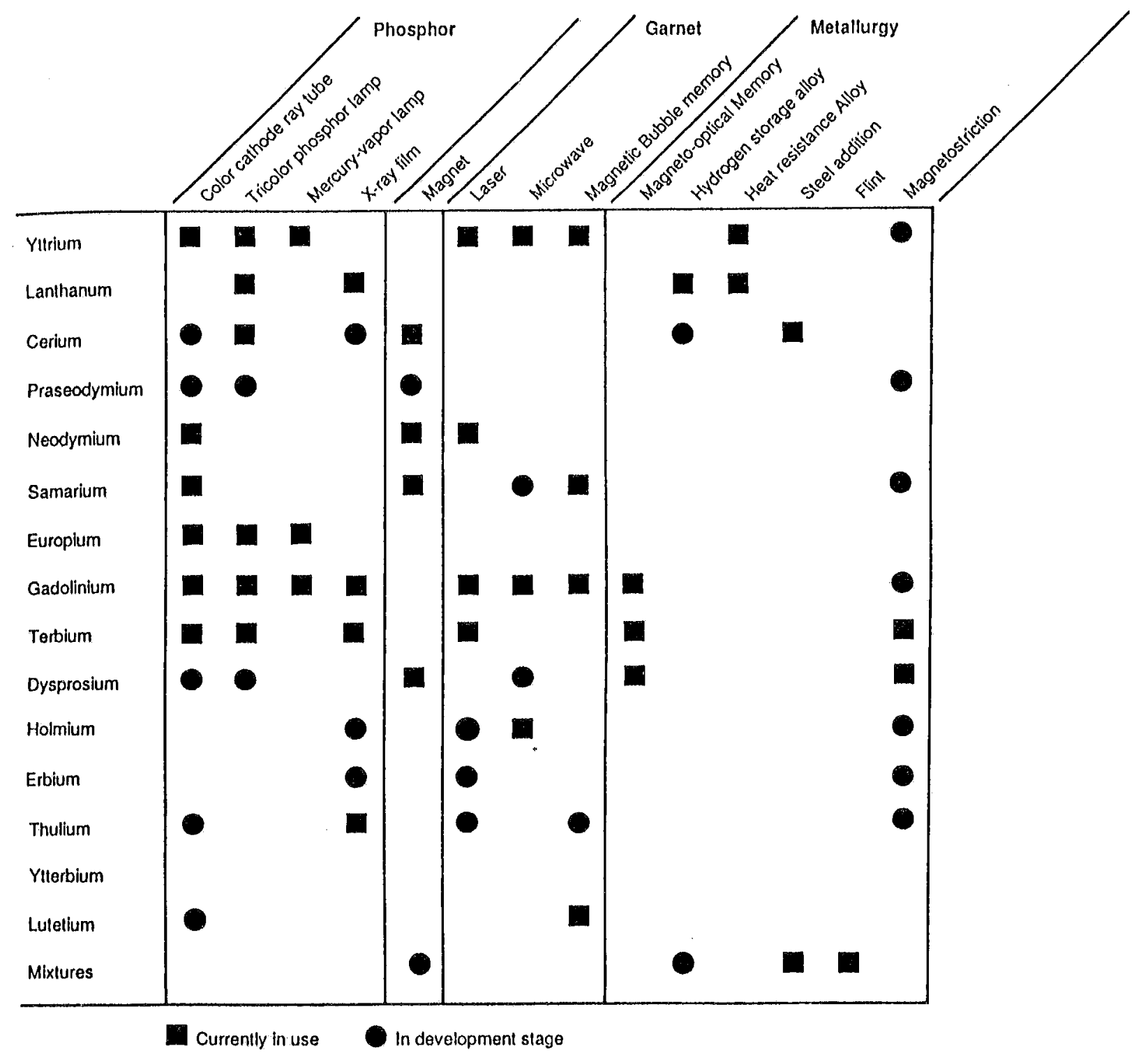

Figure 6. Applications of rare carths (continued). 
CATALYSIS

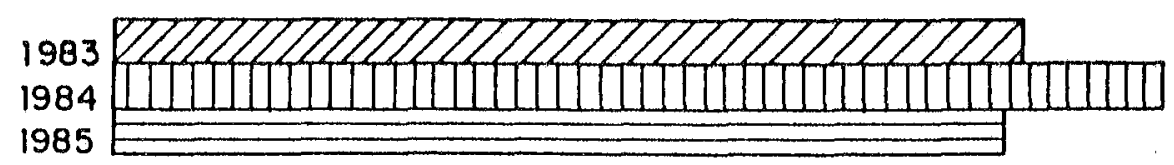

GLASS/CERAMICS

1983

1984

1985

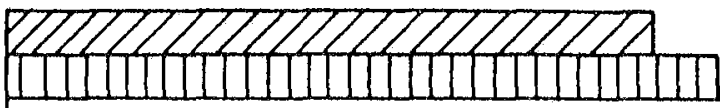

METALLURGY

1983

1984

1985

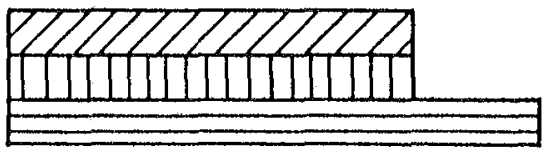

\section{ELECTRONIC/}

MAGNETIC

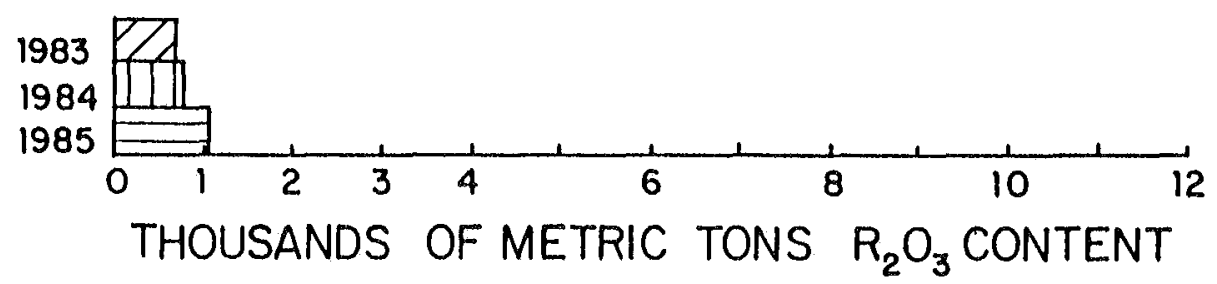

Figure 7. Worldwide major uses of rare earths.

\begin{tabular}{|c|c|c|c|c|c|c|c|}
\hline \multirow{2}{*}{ Element } & \multirow{2}{*}{\multicolumn{2}{|c|}{$\begin{array}{l}\text { Neutral Atom } \\
\text { Configuration }\end{array}$}} & \multicolumn{3}{|c|}{$\begin{array}{l}\text { 4l Configuration of } \\
\text { Known Oxidation States }\end{array}$} & \multicolumn{2}{|c|}{$\begin{array}{l}\text { Metallic State } \\
\text { No. of Electrons }\end{array}$} \\
\hline & & & $\mathrm{M}^{2+}$ & $M^{3 t}$ & $M^{4+}$ & Valence & $4 f$ \\
\hline Sc & & $3 d 4 s^{2}$ & - & 0 & - & 3 & 0 \\
\hline Y & & $4 \mathrm{~d} 5 \mathrm{~s}^{2}$ & - & 0 & - & 3 & 0 \\
\hline $\mathrm{La}$ & & $5 \mathrm{~d}^{2} \mathrm{~s}^{2}$ & - & $0_{x}$ & - & 3 & 0 \\
\hline $\mathrm{Ce}$ & $4 f$ & $5 \mathrm{~d} 6 \mathrm{~s}^{2}$ & - & $1 x$ & 0 & 3 & 1 \\
\hline $\mathrm{Pr}$ & $4 f^{3}$ & $6 s^{2}$ & - & 2 & -1 & 3 & 2 \\
\hline $\mathrm{Nd}$ & $4 f^{4}$ & $6 s^{2}$ & - & 3 & - & 3 & 3 \\
\hline $\mathrm{Pm}$ & $41^{3}$ & $6 s^{2}$ & - & 4 & - & 3 & 4 \\
\hline $\mathrm{Sm}$ & $41^{6}$ & $6 s^{2}$ & $6=$ & 5 & . & 3 & 5 \\
\hline Eu & $41^{7}$ & $6 s^{2}$ & $7 x$ & -6 & - & 2 & 7 \\
\hline $\mathrm{Gd}$ & $4 f^{7}$ & $5 \mathrm{~d} 6 \mathrm{~s}^{2}$ & - & $-7 x$ & - & 3 & 7 \\
\hline Tb & $4 f^{\bullet}$ & $6 s^{2}$ & - & 8 & -7 & 3 & 8 \\
\hline Dy & $4 f^{10}$ & $6 s^{2}$ & - & 9 & - & 3 & 9 \\
\hline Ho & $4 f^{\prime \prime}$ & $6 s^{2}$ & - & 10 & - & 3 & 10 \\
\hline Er & $4 f^{12}$ & $6 s^{2}$ & - & 11 & - & 3 & 11 \\
\hline $\mathrm{Tm}$ & $4 f^{13}$ & $6 s^{2}$ & - & 12 & - & 3 & 12 \\
\hline $\mathrm{Yb}$ & $4 f^{14}$ & $6 s^{2}$ & $14 r$ & 13 & - & 2 & 14 \\
\hline Lu & $4 f^{14}$ & $5 \mathrm{~d} 6 \mathrm{~s}^{2}$ & - & -14 & - & 3 & 14 \\
\hline
\end{tabular}

Figure 8. Electronic structures of rare carths. 
it a greenish color. Other rare earths produce a violet or pink. In certain chemical combinations cerium is widely used for decolorizing glass (e.g., pop bottles) and for polishing colored glass.

Most uses of rare earths require relatively high purity, $99.99 \%$ or better. Yttrium, lanthanum, and gadolinium are host materials (Figure 6) while the rest are dopants used to give special properties. Cathode ray tubes (TV tubes) use dopants to produce various colors. Rare earths in tremendous volumes have great potential in energy-saving tricolor phosphor lamps, especially if the energy crisis worsens. Gadolinium is used in mercury vapor lamps and $x$-ray films because of its heavy mass and good stopping power. Magnets use neodymium and samarium, and some cerium and dysprosium, and require only a $90 \%$ to 95\% purity. Lasers, however, require higher purity as do microwave applications (garnets, for example) and magnetic storage devices. Finally, there are the metallurgical uses (Figure 6), such as magneto-optic memories which require amorphous alloys of gadolinium, terbium, and dysprosium. Hydrogen storage requires primarily lanthanum and some cerium. Heat-resisting, high-temperature alloys use lanthanum and yttrium primarily because of the high-temperature oxidation erosion resistance. Rare earths are widely used as additives in the steel industry.

Figure 7 shows the magnitude of markets in metric tons of rare-earth oxide content for various years. By volume, the uses for catalysts are followed very closely by glass and ceramics uses. Metallurgy uses primarily rare-earth mixtures although some high concentrates may also be used. Separated rare earths are used in electronic and magnetic applications. The tonnage used is quite small, but that is where the dollar values are. This breakdown is provided by the U.S. Bureau of Mines, and I think needs more details.

\section{Properties of Rare Earths}

Similarities. Rare-earth properties are derived from their electronic configurations (Figure 8) which also determine how they are used. It is interesting that most of these elements have one more $f$ electron in the ground state than in the solid state. This has little effect on most industrial applications. The situations with which we will be concerned are the $4 f$ configurations of the known oxidation states which are the $2^{+}, 3^{+}$, and $4^{+}$valence states. All the lanthanides, yttrium, and scandium as well, have a trivalent state. Of course, yttrium and scandium have no $f$ electrons because they are $3 d$ and $4 d$ transition elements. Lanthanum generally does not have an $f$ electron. Cerium can have one electron, but it can also be oxidized to a tetravalent state and have no $f$ electrons. Praseodymium can also be oxidized to a tetravalent state, going from two $f$ electrons in $\operatorname{Pr}^{+3}$ to one $f$ electron in $\mathrm{Pr}^{+4}$. The same occurs in $\mathrm{Sa}^{+2}$ and $\mathrm{Eu}^{+2}$ which will capture an electron in the $f$ shell giving samarium six $f$ electrons instead of five, and europium seven electrons instead of six. Terbium can go tetravalent and can go from 13 electrons to a completed shell. It is understood from basic quantum mechanics that half-filled, fully-filled, or empty shells tend to be stable states. These properties are important. Cerium can be easily separated from the rest of the rare-earth mixtures by using the oxidation state. The same thing is true for europium, samarium, and, to a lesser extent, terbium. We can separate some rare earths fairly inexpensively using different oxidation states. But, since most of the other rare-earth elements are all trivalent, this valence cannot be used as a basis for separation. 
These configurations (Figure 8) govern properties and uses of rare earths. Most of cerium's uses are based on the tetravalent state with only a few applications requiring the trivalent state. Europium in the divalent and trivalent states is used in phosphors. One state provides the red color; the other provides blue.

Some applications depend on the number of $f$ electrons in a rare-earth element. It is important to remember that in the trivalent state lanthanum has no $f$ electrons. As we move along the periodic table for lanthanides, the number of electrons increase by one until there is a completely filled $4 f$ shell (14 electrons) at lutetium. There can be some exceptions.

The metallic state is shown in the right-hand column of the central diagram on Figure 8. Most elements are trivalent with the exception of europium and ytterbium which tend to be divalent, thus affecting some of their properties. The basically identical outer electronic configuration governs most chemical and metallurgical properties. Its effect depends on the outer valent state which is trivalent for most rare earths. The $f$ electrons have only a small effect. The ionic radii (Figure 9) change from about $1.06 \AA$ to about $0.85 \AA$ in a very smooth function and variation. This gradual variation makes it extremely difficult to separate the rare earths. Liquid extraction techniques or ion exchange must be used in many, many stages because the basic chemical properties are so similar with one minor variation because of the slight change in ionic radii. This can be a blessing in a sense because we don't have to separate the mixtures. But that blessing becomes one of the difficulties when separation is desired.

I have people call me sometimes with stories. One man said, "I've got a deposit with $0.1 \%$ lutetium in it, and I know lutetium sells for $\$ 50,000$ a pound, so I want to separate out the lutetium, and I'm going to make lots of money." If he has a very small deposit, he is not even going to recover his cost of separating the lutetium. Separation is extremely difficult; only large modern plants can separate all the rare earths at a volume and cost that would make it economically feasible.

The metallic radius and electronegativity are plotted with respect to atomic number in Figure 10. Metallic radii, at the bottom of the chart, indicate a smoothly varying function in the trivalent elements. Note how much bigger the metallic radii are in divalent europium and ytterbium. Cerium is anomalous in the metallic state because it has a tendency to go tetravalent which shows up in a deviation from the curve. Electronegativity (Figure 10) is almost constant; it changes very, very little. Electronegativity varies by only $4.1 \%$ across the series with deviations again for the divalent elements and cerium. The metallic radii vary by about $7 \%$, almost twice the percentage variation of electronegativity making it the dominant property on behaviors of rare-earth materials.

The $4 f$ electrons, although they are inner and not valence electrons, are responsible for some basic properties. Figure 11 indicates melting points of the lanthanides. One unusual feature, primarily of the metallic systems, is that lanthanide melting points are extremely low compared to those of all the other elements in the periodic table, including scandium and yttrium. Lanthanum and the lanthanide series should have higher melting points, as if there were no $4 f$ interaction. But $4 f$ electrons do have an effect. They exhibit what is known as "hybridization" of the $f$ electrons with the outer conduction electrons ( $s$ and $d$ electrons) which keeps these melting points low. The amount of $4 f$ fractional hybridization gets smaller and smaller as you approach lutetium at the end of the lanthanide series. Again we see anomalies in the melting points for divalent and trivalent materials. Most have a high 
Figure 9. Ionic radii of the lanthanides.
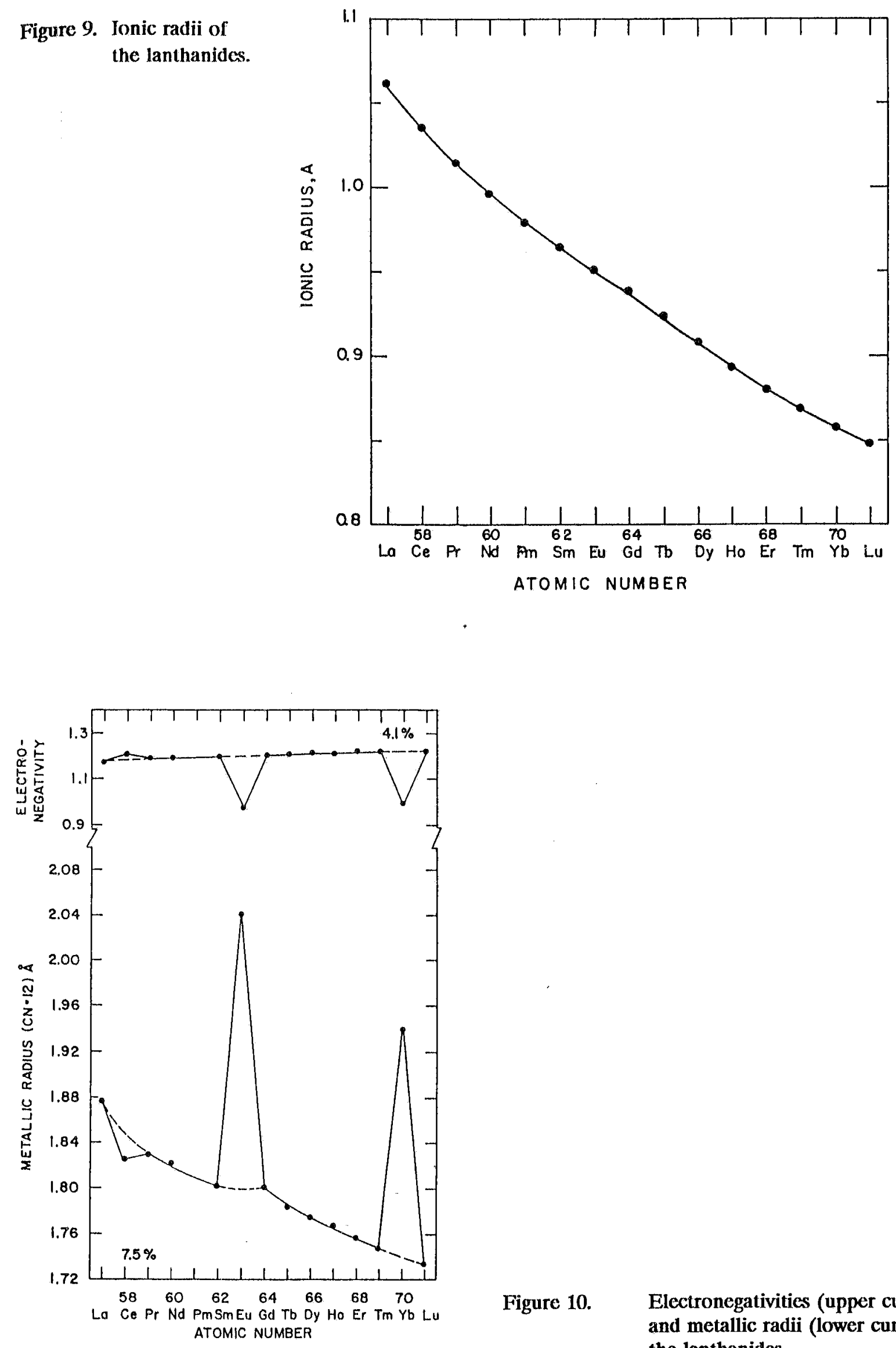

Figure 10. Electronegativities (upper curve) and metallic radii (lower curve) of the lanthanides. 


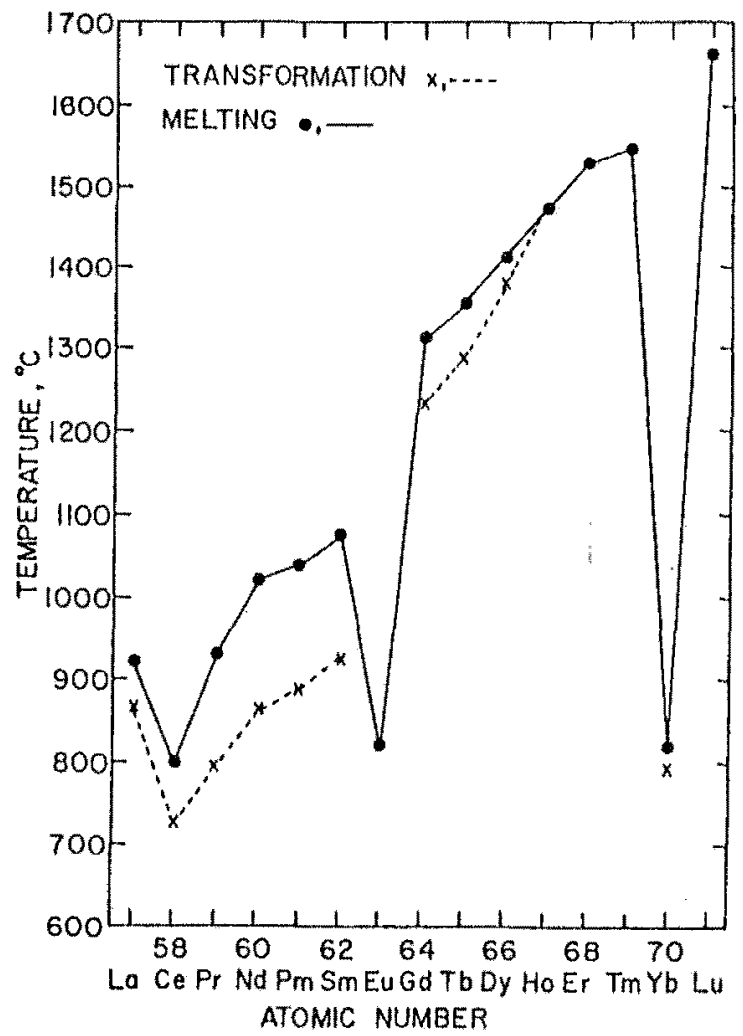

Figure 11. Transition points betwcen crystaline forms and melting points of the lanthanides.

1. They are extremely difficult to separate from one another.

2. Over $90 \%$ of commercial utilization is based on mixtures as derived from ores.

3. Most scientists or engineers (who are not rare earthers) believe that if you know something about one rare earth you know it about all of them.

Figure 12. Similarities of rare carths. 
temperature of fusion, and their bodies go cubic before melting. Mostly this is included in the transformation.

Figure 12 lists the similarities among rare earths. Rare earths are extremely difficult to separate mechanically. For one thing, they are trivalent materials with very small changes in ionic radii. Ninety percent of commercial utilization is based on mixtures derived from ores. Most scientists or engineers who are not familiar with this field believe that if you know something about one rare earth, you know about them all. That's not quite true. What I know about yttrium, for example, will apply only to some extent to other rare earths, and there are many exceptions.

Differences. Figure 13 lists some major differences in the rare earths. For example, at below $1,000^{\circ} \mathrm{C}$ the vapor pressures of lanthanum and ytterbium differ by more than one billion. Ytterbium is divalent and lanthanum is trivalent; this valence electron makes that big difference! Such a big a difference cannot be found between other similar elements in the periodic table.

The melting points of the two end members of the series (lanthanum and lutetium) differ by a factor of about 2 with the other rare earths lying between them. Again, that's unusual because the melting points of any other group of related elements in the periodic table vary by only a couple hundred degrees, maybe $300^{\circ}$. This difference $\left(700^{\circ} \mathrm{C}\right)$ is about twice as much as one would normally expect from a group of similar elements, and is due to the internal $4 f$ electrons.

Other extreme properties are the conditions for superconductivity and ferromagnetism. These conditions are essentially mutually exclusive. Lanthanum was an excellent superconductor before the high $\mathrm{T}_{c}$ days and has about the second highest transition temperature. Gadolinium, on the other hand, is a good ferromagnet. In the same series of elements, we have two diverse properties.

\section{Major Rare-Earth Ores and Ore Deposits}

Bastnaesite, monazite, and xenotime are the three major rare-earth ores; representative formulas and elemental distributions are shown in Figure 14. Bastnaesite is a fluorocarbonate with an approximate formula $\mathrm{RFCO}_{3}$ (rare earth, fluorine, and carbonate). The $\mathbf{R}$ distribution is basically one-third lanthanum, one-half cerium, and the rest divided among the other rare earths. $\mathbf{R}^{\prime}$ in the formula means primarily samarium and gadolinium with perhaps a bit of yttrium. While other bastnaesites are slightly different, this represents the basic pattern. This ore is from Molycorp's Mountain Pass, California mine. About 40\% of rare earths' current use is derived from bastnaesite, most coming from this deposit.

Monazite is another of the three major ores; it is a phosphate with the chemical formula $\mathrm{RPO}_{4}$ and $\mathbf{R}$ is primarily composed of light lanthanides. Relatively speaking, monazite contains a bit less lanthanum and cerium and more praseodymium and neodymium. It also contains samarium and some of the heavy lanthanides and yttrium. Generally yttrium is chemically assigned to the heavy fraction of the elements, although its atomic number is only 39. Most monazites are quite similar in composition to this typical Australian monazite (Figure 14). These examples show a difference in mixtures. You cannot substitute bastnaesite for a phosphate in carbon arc applications; monazite will do what a bastnaesite 
will not because the monazite rare-earth distribution is just right. A mixture of rare-earth fluorides derived from monazite in the core of a carbon arc gives a balanced and desirable sunlight color rendition in spotlights and movie cameras. Hence, anything that uses arc lamps usually has a monazite-derived fluoride in it.

Xenotime is the other main ore but comprises only a few percent of total rare-earth ores used. It contains a greater abundance of heavy rare earths and lacks the larger amounts of lighter rare earths present in bastnaesite and monazite. Xenotime has a small amount of cerium and neodymium, but the heavy rare earths predominate. There is gadolinium, dysprosium, holmium, erbium, and then yttrium at a proportion of $60 \%$. This sample is from Malaysia, but there are xenotimes in Australia and China.

The rare-earth ore deposits on the worldwide distribution map (Figure 15) are important despite the low percentage of concentration. Rare earths are found concentrated in uranium tailings as a result of the separation process. Dennison mines in Elliot Lake, Ontario, Canada, is one of the best sources of yttrium oxide, which Molycorp and Dennison have an agreement to extract. Another site is Guangdong which the Chinese are pushing for production. The Chinese deposit is an ion-exchange-type clay containing a good distribution of heavy rare earths. We may be seeing more of that product. There are a few other sites which have recently been reported, but the three most important sites are Mountain Pass (bastnaesite), Australia beaches (monazite), and Malaysia (xenotime).

Figure 15 is a schematic of rare-earth production and separation flows throughout the world, The Molycorp plant in Mountain Pass, California, for example, sends ore to Louviers, Colorado, then to Dennison mines in Canada where it is processed. The processed ore goes to Japan and China and comes back to the U.S. The deposit in Brazil is mostly monazite; this goes to France, the U.S., and Europe. There is a small monazite deposit in Florida.

Malaysia markets both xenotime and monazite which undergo some crude processing before going to Europe and Japan. Monazite is also found in beach sand in Sri Lanka, India. After some processing there, India then sends it to Japan, Europe, and the U.S. Monazite is mined at two major deposits in Australia, but no processing is done in Australia; ore is sent to Japan or Europe. There are other deposits there, but they are not economically viable at present.

China's Balto region has special ore containing both bastnaesite and monazite. The Yue Long plant in Shanghai is the largest processing plant. There is some xenotime, ion exchange clays, and monazite in China and other, smaller processing plants there. There are many Japanese companies in China, such as Shin-etsu of Mitsubishi Chemical Industries and Santoku of Mitsubishi Metal Industries. Not all do processing, but they manage the ore and ship it to other places.

These are the main producers in the world. These are Alaska's competitors, or your allies if you negotiate agreements with them. There are smaller resources in South Africa and Korea, but they do not seem to be particularly viable at the present. There are also products out of Treibach, Germany, and Kjeller, Norway. 
1. The vapor pressure of $\mathrm{La}$ and $\mathrm{Yb}$ differ by $10^{10}$ (more than one billion) at $1027^{\circ} \mathrm{C}(1300 \mathrm{~K})$.

2. The melting points of the two end members of the lanthanides differ by about a factor of two, while the remaining trivalent lanthanides lie between these two extremes.

3. One member is an excellent superconductor (La) and another member is a good ferromagnet (Gd).

Figure 13. Differences in rare earths.

Bastnaesite (fluorocarbonate) $\mathrm{RFCO}_{3}$ $32 \mathrm{La}, 40 \mathrm{Ce}, 4.4 \mathrm{Pr}, 13.5 \mathrm{Nd}, 1.1 \mathrm{R}^{\prime} \quad$ California

Monazite (phosphate) $\mathrm{RPO}_{4}$ (lights)

$20 \mathrm{La}, 45 \mathrm{Ce}, 5 \mathrm{Pr}, 18 \mathrm{Nd}, 5 \mathrm{Sm}, 2 \mathrm{Gd}, 2 \mathrm{Y}, 3 \mathrm{R}$ ' Australia

Xenotime (phosphate) $\mathrm{RPO}_{4}$ (heavies)

$5 \mathrm{Ce}, 2 \mathrm{Nd}, 2 \mathrm{Sm}, 4 \mathrm{Gd}, 9 \mathrm{Dy}, 2 \mathrm{Ho}, 5 \mathrm{Er}, 6 \mathrm{Yb}, 61 \mathrm{Y}, 4 \mathrm{R}$ ' Malaysia

Figure 14. Average composition of rare-earlh ores. 


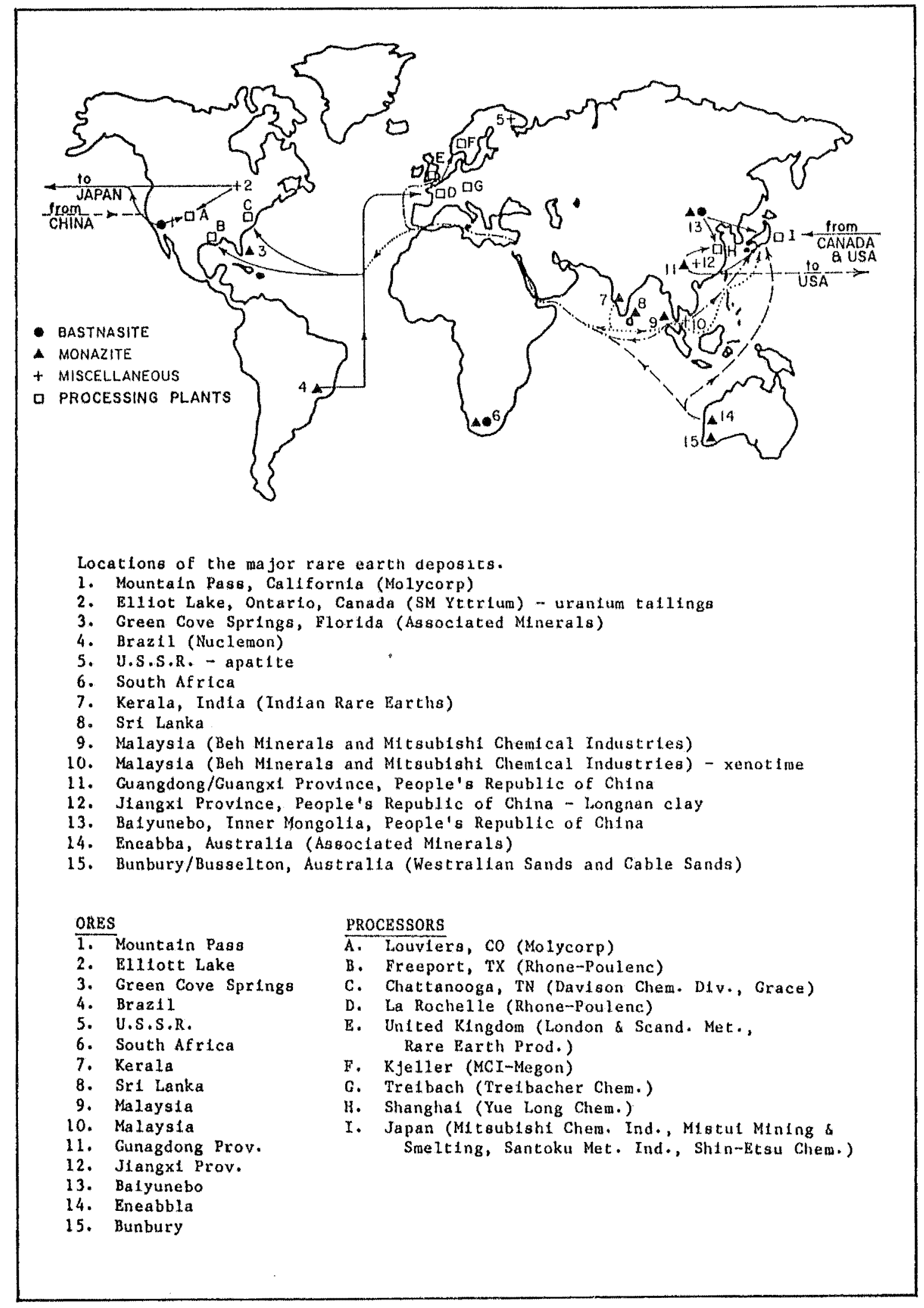

Figure 15. Locations of major rare-earth deposits and processing facilities. 


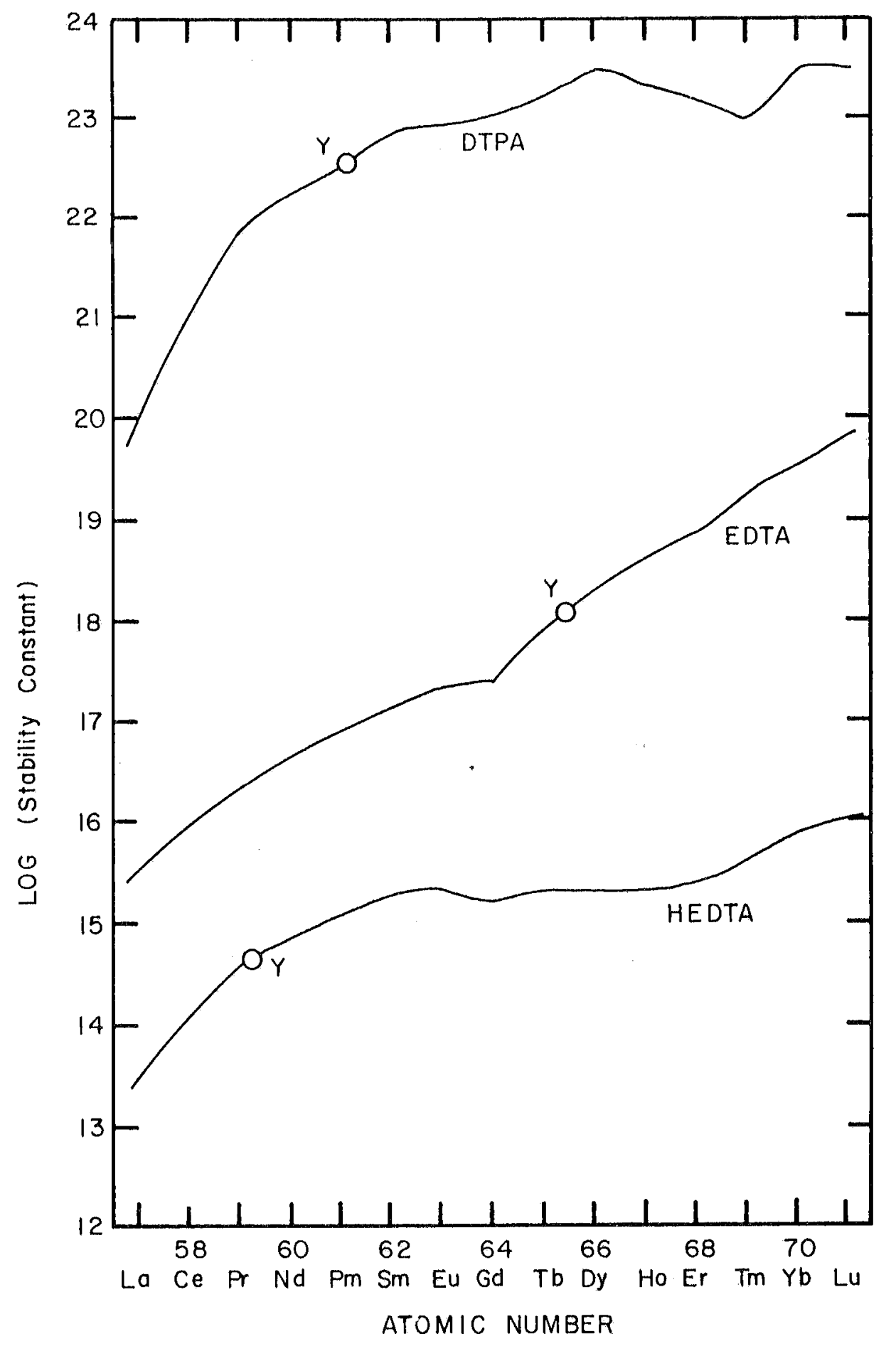

Figure 16. Stability constants for complexation of lanthanides and ytterbium (Y) with ethylenediaminetetraacetic acid (EDTA), pronated EDTA (HEDTA), and diethylenetriaminepentaacetic acid (DTPA). 
stability constants (EDTA), K

$\log \mathrm{K}_{\mathrm{Gd}}=17.37$

$\log \mathrm{K}_{\mathrm{Tb}}=17.93$

separation constant, $\alpha$

$\alpha=\frac{\mathrm{K}_{\mathrm{Tb}}}{\mathrm{K}_{\mathrm{Gd}}}=3.63$

number of steps, $n$

if the initial concentration of $\mathrm{Gd}$ is $4 \mathrm{x}$ that of $\mathrm{Tb}$, as in xenotime, then

$\alpha=4\left(\mathrm{c}_{\mathrm{Tb}} / \mathrm{c}_{\mathrm{Gd}}\right)=3.63$ where $c$ is the final concentration after separation

$\mathrm{c}_{\mathrm{Tb}} / \mathrm{c}_{\mathrm{Gd}}=0.9075^{\mathrm{n}}$

$\begin{array}{llllll}\text { Tb purlty } & 90 \% & 99 \% & 99.9 \% & 99.99 \% & 99.999 \%\end{array}$

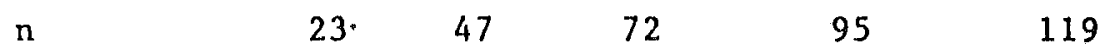

Figure 17. Simplified separation of two lanthanides Gadolinium and Terbium.

1. Similarity of Chemical Behaviors

2. $4 f$ Electron (or Its Absence)

3. Unusual Valence States

4. Nuclear

Figure 18. The four groups of applications. 


\section{Separation of Rare Earths}

The stability constants of rare earth complexes (Figure 16) are an important parameter. The constant indicates the stability of a particular complex, such as ethylenediaminetetra-acetic acid (EDTA) bonded with the rare-earth oxide. Different rare earths associate with variable strength with EDTA. The greater the difference in stability of rare-earth complexes, the greater the difference in bond strength, and the easier the separation. For example, cerium is about 1,000 times more weakly bonded by EDTA than ytterbium. The initial steep curve on the monoprotonated EDTA (HEDTA) line shows a large variation in bonding strength, and one could get a pretty good separation of lights. The stability constant flattens out more in the heavy rare earths where you're not going to get any separation at all because they all have the same tendency to complex with EDTA. With diethylenetriaminepenta-acetic acid (DTPA) you again have a very nice separation for lights. EDTA works pretty well for ion exchange as shown by the nearly linear function with a good slope. These same basic principles also hold for liquid-liquid extraction.

Note the position of yttrium, the Y superimposed on the curve (Figure 16). With HEDTA as the solvent, yttrium has the same bond strength as the lights; with EDTA, the same as the middle of the heavies; and with DTPA it falls somewhere just near the breaking point between the lights and the heavies. So, as you select the right solvents for liquid-liquid extraction, you can separate yttrium into the same group as the light rare earths. By then changing the solvent, you can change the extraction process to separate out the heavy rare earths. In principle, yttrium is easily separated to really high purity in this two-step process of liquid-liquid extraction. A purity of $99.99 \%$ to $99.999 \%$ is very easily achieved by liquidliquid extraction because you do not have to use many stages.

Separating rare earths and individual lanthanides from one another cannot be done just by changing agents, however. You can improve separation by going to another complexing agent, but not a whole lot can be done. The sequence is pretty much the same and can't be shifted around. Most rare earths other than yttrium require a big solvent extraction plant for $99.999 \%$ purity. Crude separation will bring purity to maybe $99 \%$ or $99.9 \%$, and ion exchange will purify further with each pellet basically being an extraction stage.

The mathematics of these extraction processes are shown on Figure 17. Numbers are taken from the EDTA plot; this is the log of the stability constant of these numbers. The separation constant then is given by this constant. The separation constant (3.63) is good for neighboring lanthanides. We can find the number of separation steps to achieve a given level of purity. If we assume the gadolinium concentration is four times that of the terbium, such as in xenotime, then we have the separation constant $\left[4\left(\mathrm{c}_{\mathrm{Tb}} / \mathrm{c}_{\mathrm{Gd}}\right)\right]$, where $c$ is the final concentration. Then this equation is equal to this ratio $\left[c_{\mathrm{Tb}} / \mathrm{c}_{\mathrm{Gd}}=0.9075^{\mathrm{n}}\right]$, where $n$ equals the number of steps necessary to obtain a certain purity. In this complex, terbium is the minority. Gadolinium is going to come out much purer quite fast because it's the reciprocal of that relationship. Theoretically, 23 steps are necessary to extract just $90 \%$ pure terbium, while $99 \%$ purity would almost double the number of steps. A $99.999 \%$ purity would theoretically require 119 stages, but in practicality you would never see that number of stages.

Separation gets complicated in a real system, however, because you usually have to work with a mixture of all 15 rare earths at once. In liquid-liquid extraction, more and more stages are necessary to obtain very high purity, and it often becomes impractical when the 
amount of rare earth required is small. Higher purity will very easily result by switching from liquid-liquid extraction at $99.9 \%$ to an ion exchange column in which each little bead would be the equivalent of a stage. It simply requires more time. This is one of the problems in planning the separation of rare-earth materials.

\section{Four Groups of Rare-Earth Applications}

I have summarized rare-earth applications by breaking them into four groups (Figure 18) based on various properties: 1) the similarity of chemical element behaviors allowing mixed use or as a catalyst (such as additions to steel); 2) use of the 4 f electron, or its absence (or the half-filled $4 \mathrm{f}$ level in the case of gadolinium) for optical and magnetic properties; 3) unusual valence states such as trivalent, tetravalent, and so forth; and 4) nuclear technology applications, a special category filled from the rare earths only by gadolinium.

Additives. Some applications will depend upon the chemical stability of the rare-earth oxides, Figure 19 is a diagram indicating the free energy of formation of a particular compound as a function of temperature. The lanthanides and yttrium are shown in the shaded bands. The heavy lanthanides and yttrium are about where the calcium oxide dotted line is. The light lanthanides are just above the heavies. The more stable oxides occur lower on the chart. From this figure you can see that rare-earth oxides are among the most stable oxides formed of all known elements, comparable to magnesium oxide and calcium oxide. Europium and one or two others are less stable which has its good and bad points. As metals, they would tend to pick up oxygen very easily to form $\mathrm{R}_{2} \mathrm{O}_{3}$, so we have to take very special precautions in handling them as metals to keep contamination down.

Many applications are based on the stability of these oxides which are among the more stable in the periodic table. The same is true for rare-earth sulfides (Figure 20). Rare earths have an affinity for Group VIB elements (oxygen, sulfur, selenium, and tellurium. With this information as background we can interpret what would happen with a variety of impurities plus certain rare earths in steel. Figure 21 shows the oxides are the most stable; in this graph the heavy lanthanide metals and yttrium are represented by $\mathbf{R}^{\prime}$ and the light lanthanide metals by $R$. The oxysulfides $\left(\mathrm{R}_{2} \mathrm{O}_{2} \mathrm{~S}\right)$ are seen to be almost as stable as the oxides, while the sesquisulfide $\mathrm{Ce}_{2} \mathrm{~S}_{3}$ and the monosulfide $\mathrm{RS}$ are somewhat less so. The nitride RN and the carbides are even less stable. At one time the rare earths were used widely as additives to steel to remove the sulfur, but that use has dwindled. The other important advantage was to control the shape of a sulfide (impurity) particle that formed, but that has been superseded by calcium. Calcium sulfide is rather stable and has good shape-control properties. Some applications of rare earths are based on their ability to sequester or complex other atoms.

In another application, yttrium oxide may be added as a finely dispersed oxide to strengthen a superalloy, a conventional iron-chromium alloy. The oxide is quite stable; iron and chromium cannot reduce it, and it has good oxidation resistance. It also improves the hightemperature rupture strength of the alloy. The yield strength of the yttrium oxide stabilized superalloy is shown on the horizontal curve, while the strength of the conventional alloy is indicated as the descending curve.

Lighter flints may be the oldest use of a rare earth. Flint probably contains the richest rareearth alloy in commercial use. It contains about 50\% mixed rare earths (of which $50 \%$ is 


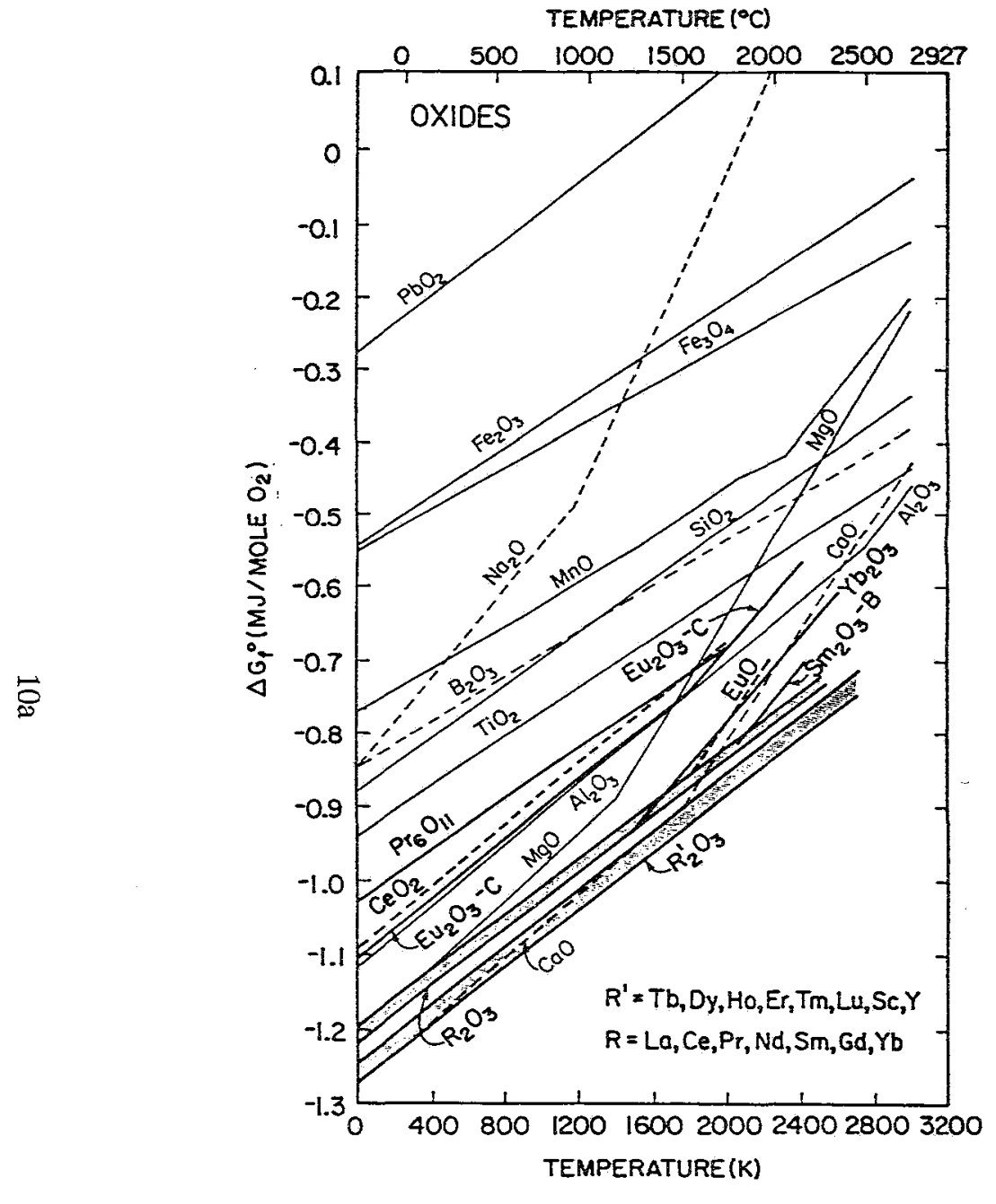

Figure 19. Temperature dependence of free energies of formation of selected metal oxides.

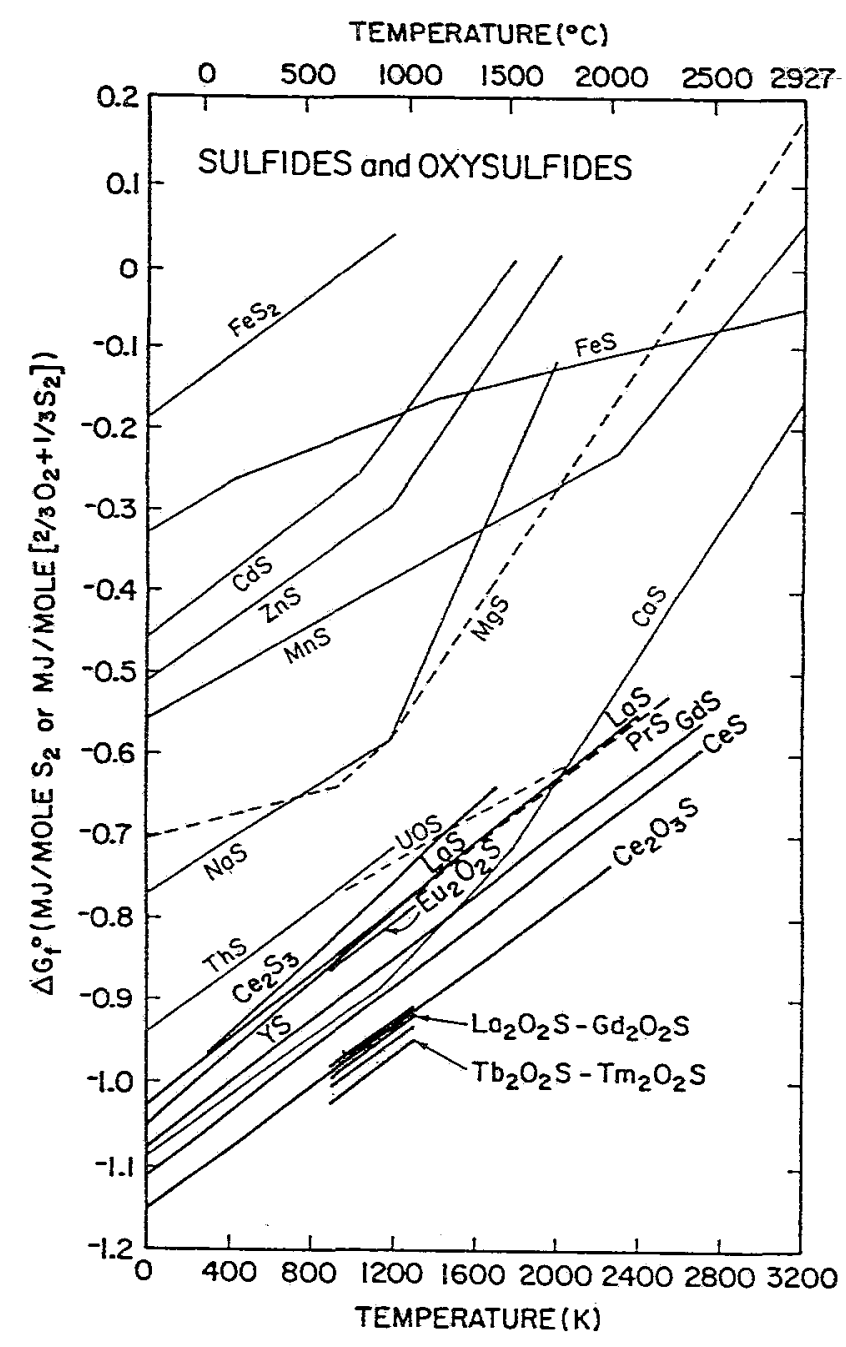

Figure 20. Temperature dependence of free energies of formation of selected metal sulfides. 


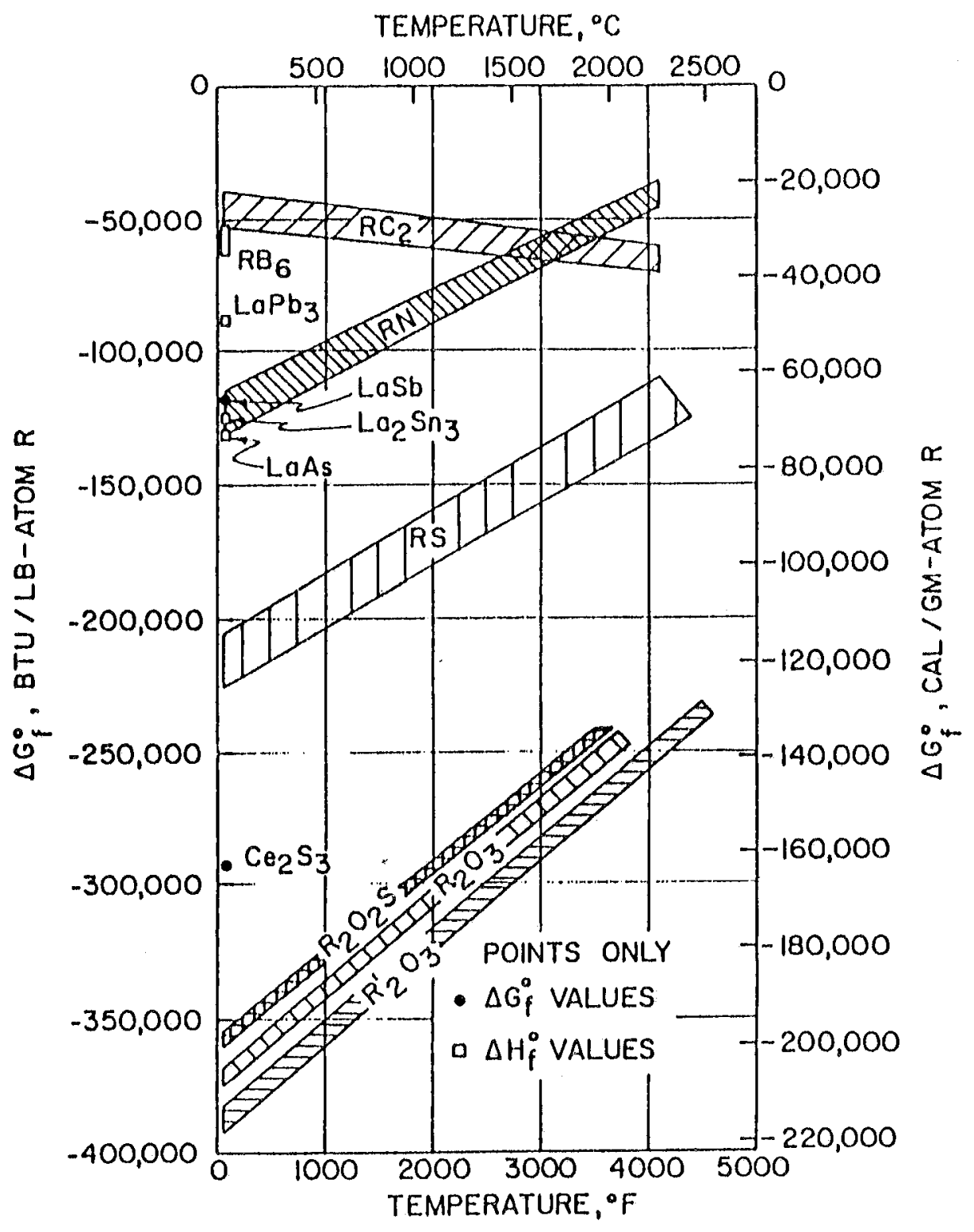

Figure 21. The standard free energies (heats) of formation of some rare earth compounds for the general reaction $R(s$ or $l)+\frac{y}{x} X(s) \rightarrow \frac{1}{x} R_{x} X_{y}(s)$, where $X=B, C, A s, S n, S b$ and $\mathrm{Pb}$, or for the general reaction $R(s$ or 1 .) $+\frac{y}{2 x} Y_{2}(g)-\frac{1}{x} R_{x} Y_{y}(s)$ where $Y=N$, O and $S$ a s a function of temperature (if known) over the range 77 to $5000^{\circ} \mathrm{F}$. The symbol $R$ represents the light lanthanide metals, while $R$ 'represents yttrium and the heavy lanthanide metals. 


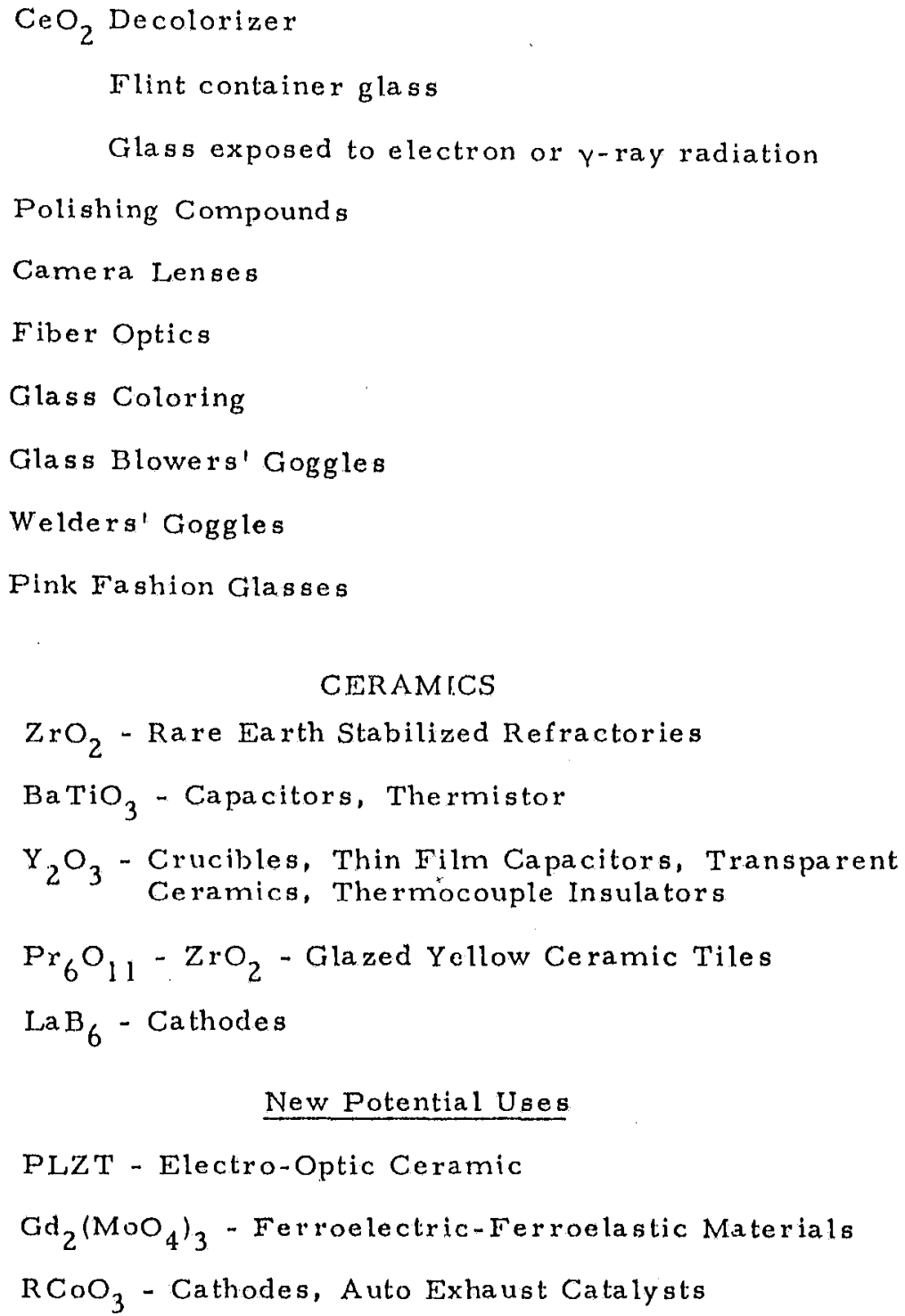

Figure 22. Glass products and processes utilizing cerium oxides and specialized compounds and their applications. 
The startling new fluorescent lamp that fits man's visual response... and

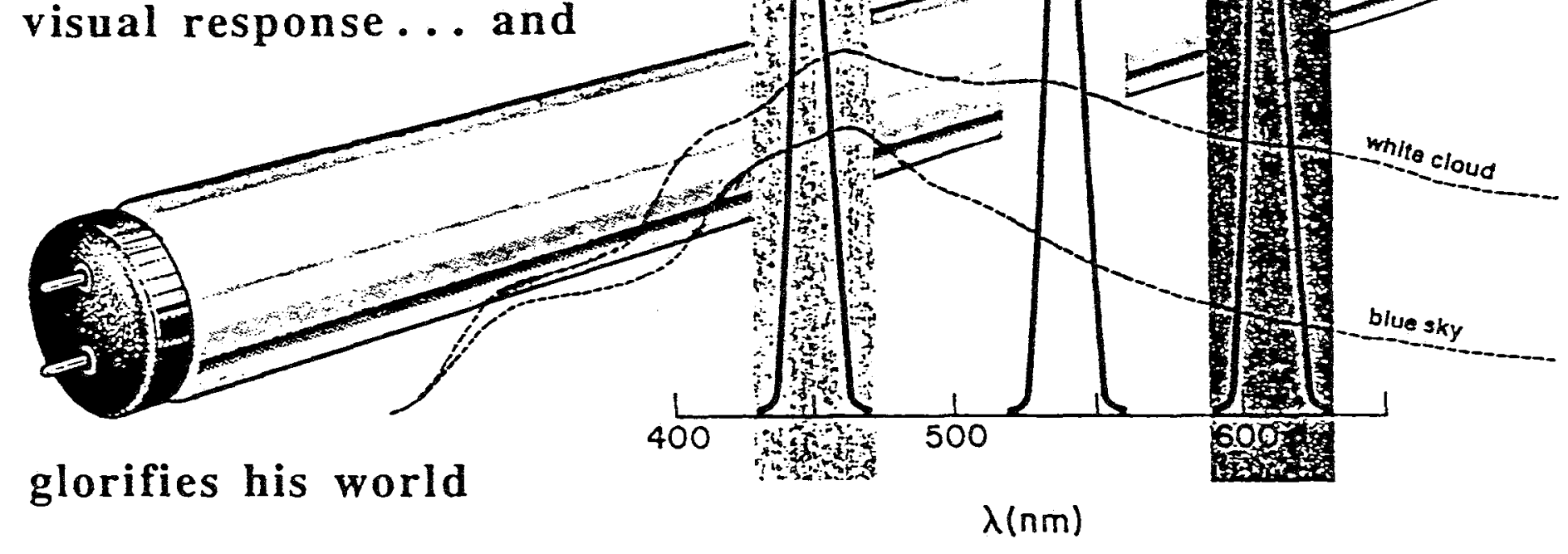

Figure 23. A "balanced light" fluorescent bulb with location of three emission bands provided by rare earths. 
cerium) and the other $50 \%$ is pretty much iron. It is very pyrophoric, and again the application is related to oxide stability. For many, many years, this was the only rare-earth chemical that one could buy at the corner drug store.

Colorizing/Decolorizing Agents. Cerium oxides are widely used as a decolorizing agent for bottles, jars, and tableware. Iron in the wrong oxidation state will discolor glass. Cerium oxide, because of its oxidizing ability on iron, will tend to keep the glass bottle clear. In the last 15 or 20 years arsenic has been replaced by cerium oxide which is cheaper than arsenic and, environmentally, people might not tolerate arsenic in pop bottles.

Other products (Figure 22) include samarium-doped glass for lasers, lanthanum oxide for lenses to modify the index of refraction, and praseodymium zirconate for the yellow in glazed ceramic tile production. The uses are diverse.

The blue color in a three-way light (Figure 23) is produced by divalent europium and the red by trivalent europium. Traditionally, sulfide silicate in glass gives the green color, but maybe today we can use a rare earth. This lamp produces three wave lengths, but as seen by the human eye, it looks like actual balanced sunlight. Roughly, two of these efficient lamps will be equivalent to three normal light bulbs while still saving energy. This market has been growing steadily for at least 10 or 15 years and has a lot of potential. The energy savings on these three-way light bulbs compensates for the fact that they are more expensive. Europium has also been used for about 25 years in color TV screens to produce the red color.

Magnetic Properties. Figure 24 illustrates the history of magnets over the last several years with respect to their magnetic power. Over 100 years ago the lodestone with a low magnetic power was all that was known. It was improved from the 1920 s to 1970 s through the advent of a series of alnico (aluminum-nickel-cobalt) formula alloy magnets. Rare-earth mischmetal and samarium alloy added greatly to the power, and today neodymium-iron-boron $\left(\mathrm{Nd}_{2} \mathrm{Fe}_{14} \mathrm{~B}\right)$ produces the most powerful magnets.

Figure 25 diagrams the coupling of moments. In the language of quantum mechanics, the light lanthanides couple with their moments parallel to one another $(\mathrm{J}=\mathrm{L}-\mathrm{S})$, while in the heavy lanthanides the moments are added $(J=L+S)$ with $J$ (the angular momentum) and $S$ being in the same direction. When rare earths are added to an intermetallic compound or transition metal such as iron, cobalt, or nickel, the spins go opposite one another or antiparallel; this the total magnetic moment. The rare earths are antiparallel to a $3 d$ element. Light lanthanides have good permanent magnet properties because the total magnetic moment of the rare earth is added to the spin moment $(L=J+S)$.

On the other hand, the heavy rare earths being parallel with one another have two moments -- the moment of the iron going one direction and the moment of the rare earth in the other direction. They tend to cancel each other out; consequently they are not very good in permanent magnets. A small amount of dysprosium may be added, but for another reason. Using light rare earths in all future permanent magnets will be an advantage as there are more lights than heavies.

Another property of rare earths making them useful for permanent magnets is that the $f$ electron tends to lock the $s$ electron on the $3 d$ electron and prevents the magnetic moment of those electrons from rotating. A second magnet would respond sympathetically, but the 
crystal field effect keeps the $s$ electron locked in and prevents it from rotating. In the case of samarium-cobalt, samarium does a very good job of locking in this moment because of its hexagonal crystal structure. Neodymium is inferior and will just allow it rotate. However, a neodymium-boron-iron magnet forms a tetragonal structure making neodymium very effective in locking in that moment while samarium is less effective.

Figure 26 shows some B (induction) versus H (field strength) curves. The larger the area under the curve the stronger the permanent magnet. You can see that samarium-cobalt and neodymium-iron-boron combinations perform much better than other compounds such as barium ferrite.

In the future, good permanent magnets will have to use a very high percentage of iron and cobalt along with a light rare earth to lock in the spin moment of the transitional element. We may develop another compound that replaces neodymium in boron-iron magnets, but I am willing to bet that it will have iron or cobalt in it and one of the light rare earths. So, if I were looking into future markets I would feel fairly confident about light rare earths.

General Motors is the largest magnet user in the world (Figure 27). GM is extremely interested in permanent magnets and has refined the neodymium-iron-boron magnet. It produces a strong field for its weight so GM can use a lower weight motor helping improve gas mileage, which by federal mandate must continue to improve.

Speaker magnets (Figure 28) used in millions of portable walkmans are about $5 \mathrm{~mm}$ thick and $25 \mathrm{~mm}$ in diameter, the size of a fifty-cent piece. You could not build that magnet without rare earths.

Superconductors. With respect to superconductivity (Figure 29), only a limited increase in the critical temperature $\left(T_{c}\right)$ occurred between 1910 and 1986. Thereupon the $T_{c}$ improved from about $30^{\circ} \mathrm{K}$ to $100^{\circ} \mathrm{K}$ with the use of yttrium-barium-copper oxide compounds, $\mathrm{T}_{\mathrm{c}}$ is the temperature below which the material is superconducting. The significance of the superconductivity breakthrough to higher $\mathrm{T}_{c} \mathrm{~s}$ is that these materials, when supercooled in customary inexpensive ways by liquid nitrogen, will pass very large currents and produce exceedingly high magnetic fields for their size. This is important for motors, information storage devices, and computers. There is a recent report that indicates a $160^{\circ} \mathrm{K}$ value for the $\mathrm{T}_{\mathrm{c}}$ of new materials.

Having achieved a high $T_{c}$, there are other technology problems and questions associated with fabricating and using these materials. These are listed in Figures 30 and 31. Material of sufficient size and shape is needed to withstand a high critical current to produce high fields. At the same time, we must be able to fabricate these materials in shapes of wires, sheets, ribbons, films, or whatever is necessary. Fabrication of films is further advanced than for other shapes which are still a major problem. Fabrication problems are essentially the same whether the superconductor is of a rare earth or another element. I think we're going to see a lot of high $T_{c}$ uses involving rare earths.

What about the rare-earth superconductor magnet? Some questions and concerns are 1) has $T_{c}$ reached another plateau and, if so, for how long; 2 ) if it is indeed merely a plateau, what role will rare earths play in future materials; 3) can the high critical current problem be solved; and 4) can we fabricate the material into a useful form? Yttrium-barium-copper oxide was the top material when this chart (Figure 29) was put together last November, and 


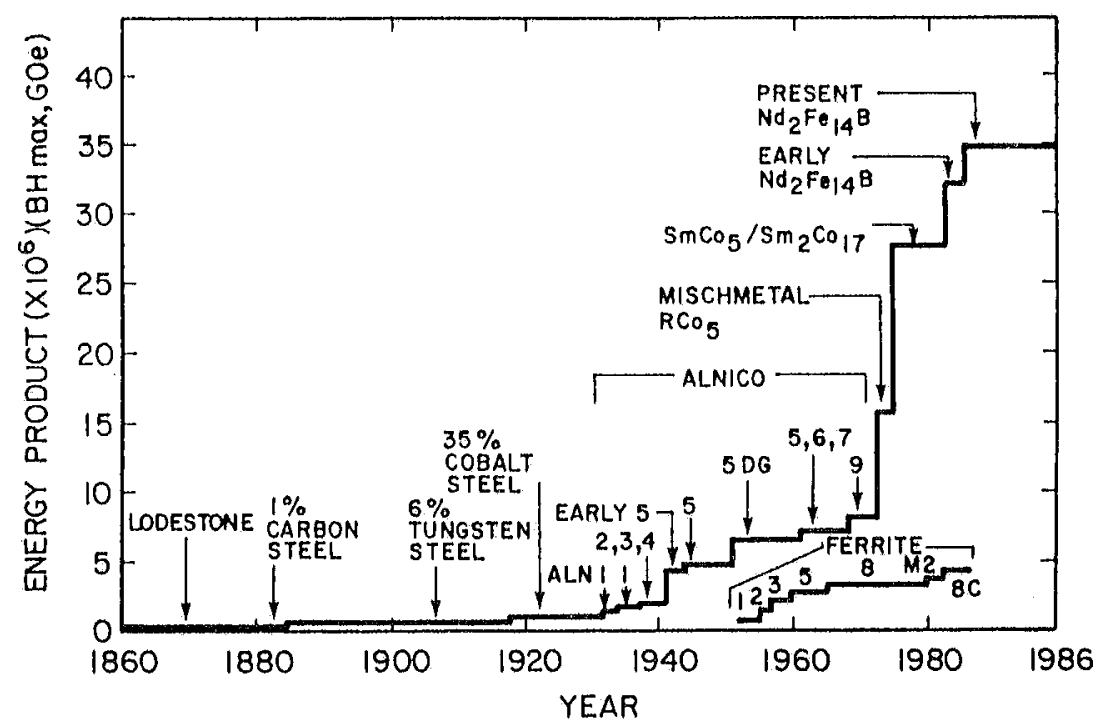

Figure 24. Comparison of various magnetic materials.

$$
\text { Lights } \quad J=L-S
$$

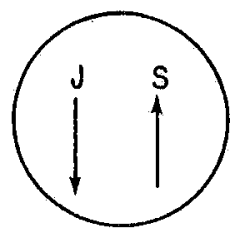

$\mathrm{R}$

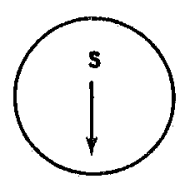

$3 d$

$\therefore$ Moments are parallel for $R(J)$ and $3 d(s)$ atoms

Heavies $\mathrm{J}=\mathrm{L}+\mathrm{S}$

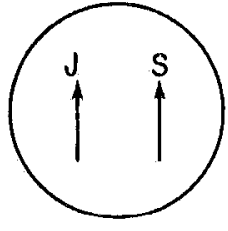

R

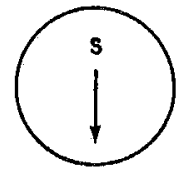

$3 d$

$\therefore$ Moments are antiparallel for $R(J)$ and $3 d(s)$ atoms

Figure 25. Coupling of moments. 


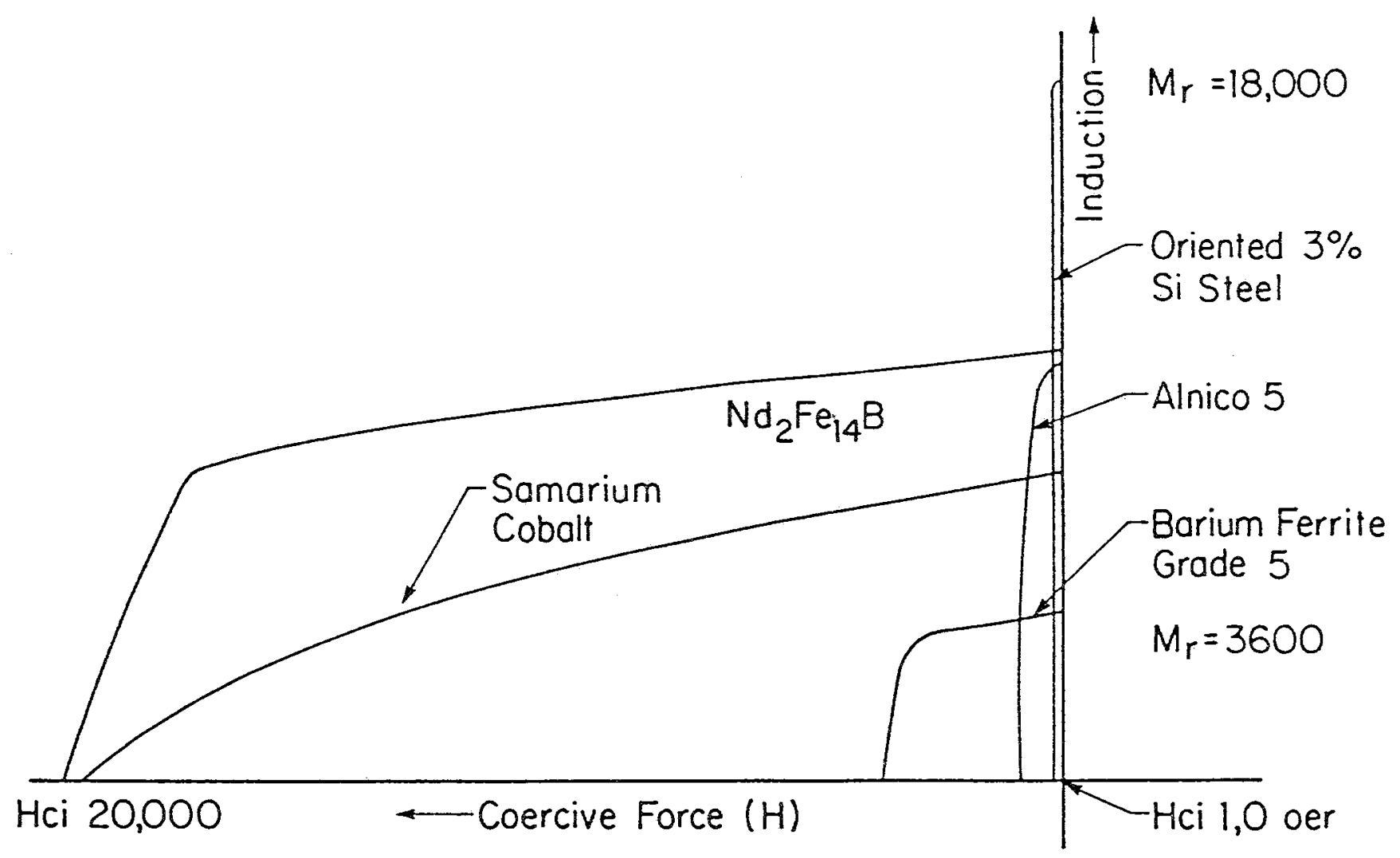

Figure 26. B versus $H$ curves for various types of magnets. The strongest magnet has the largest area under the BH curve. 


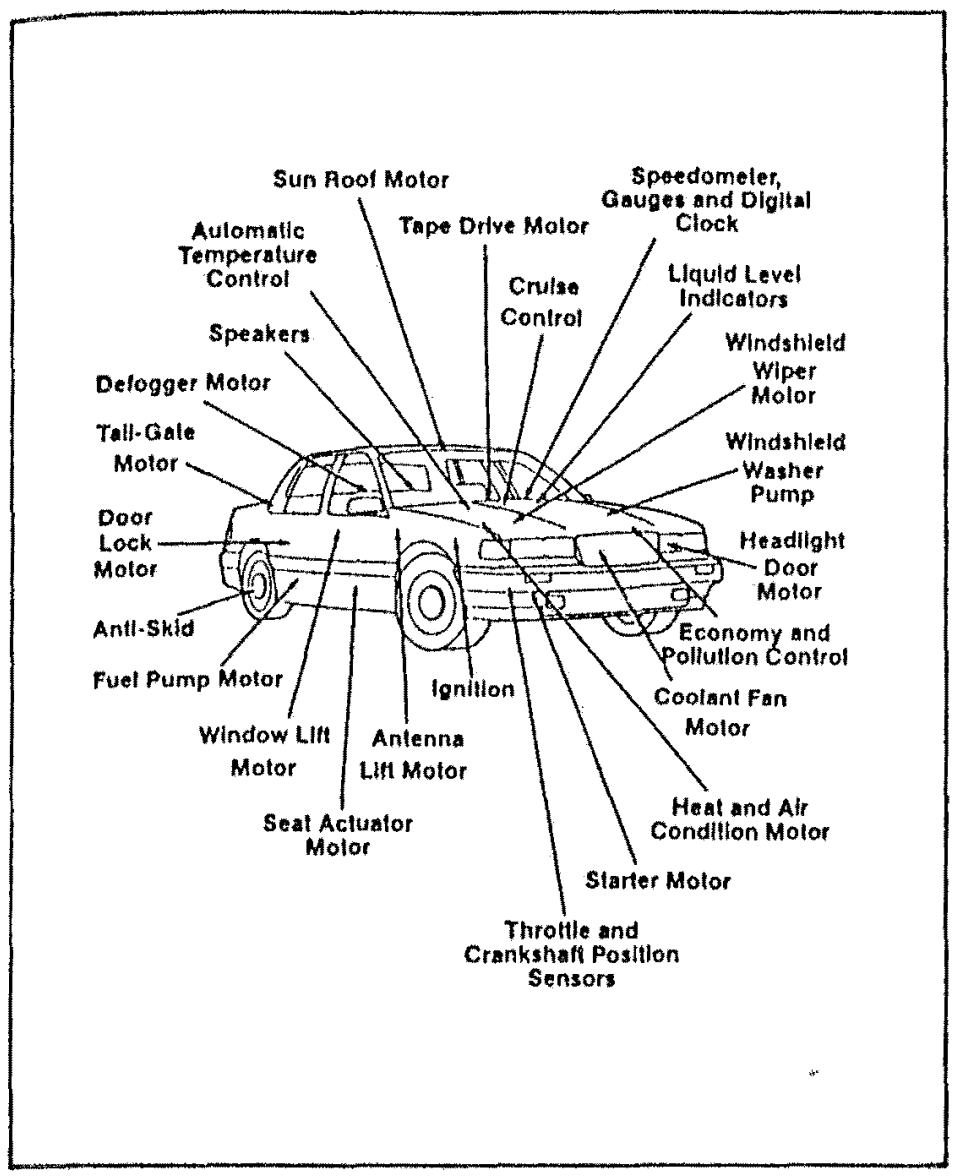

Figure 27. Vchicle parts using rarc carths in production.

Figure 28. A miniature radin headphone speaker magnet compared in
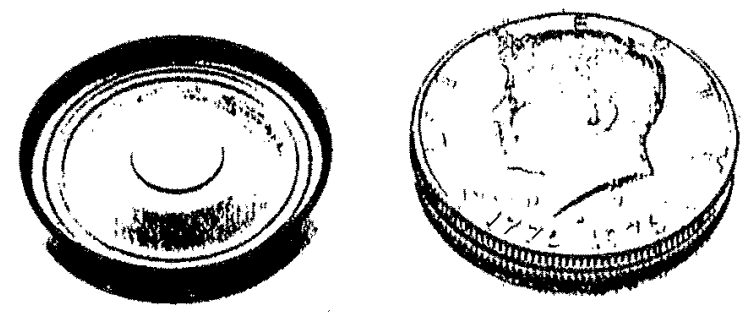
size to a half dollar. 


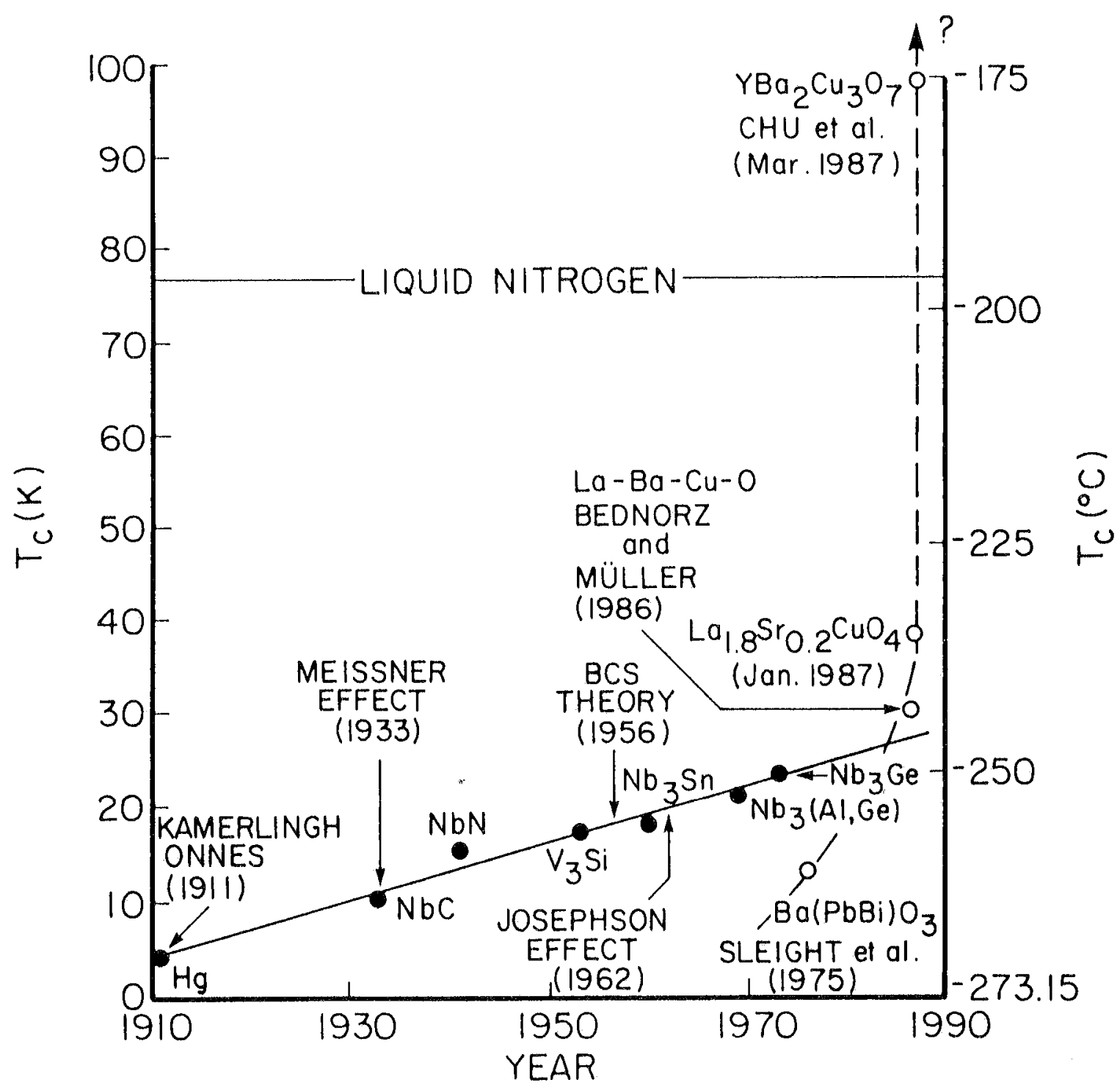

Figure 29. Plot of the known Tc, critical temperature for superconductivity, and the year of discovery of the compound. 
Need high critical currents.

Method(s) for fabricating wire, ribbons, sheets (fabrication of films - satisfactory progress)

Figure 30. Problems to be solved for full commercialization.

\section{QUESTIONS AND CONCERNS}

Has $T_{c}$ reached another plateau?

If so, how long? One year,ten years, twenty-five years? Forever?

Will there be new materials?

No, if plateau lasts forever.

Yes, if plaeau has a time period.

Will the rare earths play a role?

Can the high critical current problem be solved?

Can we fabricate the materials into a useful form?

Figure 31. Rare earth superconducting market. 
it has yet to be replaced. In less than one year the $\mathrm{T}_{\mathrm{c}}$ has risen to $160^{\circ} \mathrm{K}$. There is no theory that predicts an uppermost $T_{c}$ limit. It is my feeling that the ultimate role of rare earths may be less than it was last November. The high critical current problem can probably be solved because it is a metallurgical processing issue, but I am not certain. The rare-earth superconductor market seems pretty tenuous and of the two markets $\left(\mathrm{Nd}_{2} \mathrm{Fe}_{12} \mathrm{~B}\right.$ or high $\mathrm{T}_{\mathrm{c}}$ superconductors), I feel $\mathrm{Nd}_{2} \mathrm{Fe}_{12} \mathrm{~B}$ magnets are the best future bet.

Finally, I offer a quotation from a very famous statesman. Winston Churchill said, "It's a riddle wrapped in a mystery inside of an enigma." I think he was talking about Russia at the time, but I think it applies equally to rare earths. Thank you.

Editor's note: Dr. Karl Gschneidner is Director of the Rare-Earth Information Center (REIC) at Iowa State University, Ames, Iowa. REIC produces several publications, one of which is called the RIC News, a quarterly publication available at no charge. They also publish a monthly newsletter called RIC Inside at a subscription cost of $\$ 300$ per year, A source book is available on neodymium-iron-boron permanent magnets along with a list of references. Dr. Gschneidner is coeditor for the Handbook on Physics and Chemistry of Rare Earths. Eleven volumes are now published and Volume 12 is due in December (1990). The subscription rate (approximately $\$ 120$ ) reduces the cost of this publication about $20 \%$. 


\title{
World Rare-Earth Resources and Their Problems
}

\author{
Dr. Masaharu Kamitani \\ Chief, Mineral Resources Section \\ Mineral Deposits Department, Geological Survey of Japan
}

\section{Distribution and Occurrence}

Although rare-earth mineral deposits are widely distributed in throughout the world (Figure 1), mines actively producing rare earths as main products are actually scarce. About $65 \%$ of rare-earth ores and products are supplied from the enormous, high-grade rare-earthbearing carbonatite deposits at Baiyun Obo, China; and Mountain Pass, California. The remaining $35 \%$, mainly by-products of titanium-bearing placer deposits, are from various countries. Only a few rare earths are associated with deposits of residual weathering crusts; these are uranium-bearing conglomerates and nepheline syenites. Potential rare-earth deposits along with yttrium and heavy rare-earths have been found within alkaline complexes and alkali granites in Canada, U.S., Brazil, Turkey, and Australia.

Residual-type ore deposits (ion adsorption type) occur in South China in residual weathering crusts derived from Cretaceous granites of the Yanshanian cycle. These mines provide raw materials for high-tech industries. The crusts usually contain several thousand parts per million ( $\mathrm{ppm}$ ) of rare-earth elements. Some of them are comparatively rich in yttrium and heavy rare earths, but few ore deposits predominate in light rare earths. Cerium and europium are characteristically depleted in both deposits.

On the Kola Peninsula in U.S.S.R., 1,000 to 2,000 tons per year (tpy) of rare-earth oxides have been recovered from an apatite processing plant for phosphoric acid fertilizer. The nepheline syenites in the Khibiny alkaline complex are accompanied by $5 \%$ to $15 \%$ of fluorapatite which contains several percent of rare-earth elements.

\section{Production and Consumption}

Since 1974 world rare-earth production has increased moderately (Figure 2) as a result of growing demand from the high-tech industries such as samarium-cobalt magnets, fine ceramics, and others. Consumption of light rare-earth oxides for petroleum cracking catalysts, however, radically decreased by $25 \%$ in 1987 due to the U.S. 1985 antipollution measures. Production of bastnaesite containing mainly lanthanum and cerium from the Mountain Pass carbonatite mine in California has decreased by $30 \%$.

Since China appeared on the world rare-earth market in the 1980s, its production has increased remarkably (Figure 3), mostly from the Baiyun Obo carbonatite mine in Inner Mongolia. Yet worldwide output of monazite, a by-product of beach, dune, and river placer deposits, has only moderately increased. The main producers of monazite are Australia, India, Malaysia, and Brazil, but there are also potential areas of placer monazite on the south coast of China, Richard's Bay of South Africa, and the Nile Delta in Egypt. 
Other types of ore deposits have been developed recently in South China, Canada, and Brazil. A heap leaching method has been used in residual crusts on granitoids, and a small amount of roughly refined rare-earth chlorides from Jianxi and Guangdong provinces in China have been exported to Japan and other consuming countries. These products are characteristically rich in middle and heavy rare earths.

The Blind River uranium-bearing conglomerate-type ore deposits in Canada have produced a small amount of yttrium concentrates recovered from uranium-leached residues. Apatite, found with alkaline rocks and orthomagmatic iron ore deposits, is also a promising rare-earth resource.

While no detailed data for world rare-earth consumption is available, data from the U.S. and Japan, two major rare-earth consuming countries, indicates demand for various elements, The U.S. consumes approximately $25 \%$ of all world production, mainly for petroleum catalysts, metallurgical uses, ceramics, and glass industries (Figure 4), while Japan's use is mostly for ceramics and glass industries. The use of samarium, neodymium, and europium oxides for phosphors and electronics has rapidly expanded since the 1980s (Figure 5). While world consumption of europium is not great, Japanese industries have used approximately 10 tpy of its oxide, equivalent to $40 \%$ to $50 \%$ of world consumption. Neodymium-cobalt magnets are replacing samarium-cobalt in the marketplace, so demand for neodymium oxide will increase remarkably in the 1990s.

\section{Main Rare-Earth Ore Deposits}

Baiyun Obo Carbonatite Deposit, China. Originally exploited as an iron mine in the 1940s, bastnaesite and monazite have been recovered from the mine dumps since 1965. Many ore bodies consisting mainly of magnetite, hematite, rare-earth minerals, and fluorite occur within the dolomite and calcite carbonatites intruded into the Baiyun Obo group of Proterozoic age (Figure 6).

The east and main ore bodies are the largest actively exploited for iron and rare earths. Both ore bodies extend roughly east-west for 1 to 2 kilometers then dip sharply toward the south. Bastnaesite and monazite are widely dispersed in carbonate rocks, but are also closely associated with magnetite, hematite, and fluorite. Massive rare-earth ore and fluorite rareearth ore zones contain primarily rare earths and iron. The average grade of the east and main ore bodies is assumed to be $6 \%$ rare-earth oxides. Total reserves were reported to be about 35 million tons (Sun Hong-ru 1984).

In China 13 carbonatites are distributed within and on the margins of the continental crusts. Miaoya and Wushan carbonatites are accompanied by relatively high amounts of bastnaesite. The Wushan carbonatite mine located southwest of Shandong Province has been worked by small-scale mining techniques and produces an estimated 1,500 tons of rare-earth oxides annually.

Mountain Pass Carbonatite Deposit, California. The second largest carbonatite deposit reserves occur in Precambrian metamorphic rock. The Sulphide Queen carbonatite body is 720 meters long, 210 meters wide, and is composed mainly of bastnaesite, barite, and carbonates. Proven ore reserves of rare-earth oxides are estimated at 5 million tons with an average grade of $7 \%$ rare-earth oxides, the highest grade of world carbonatites. However, 


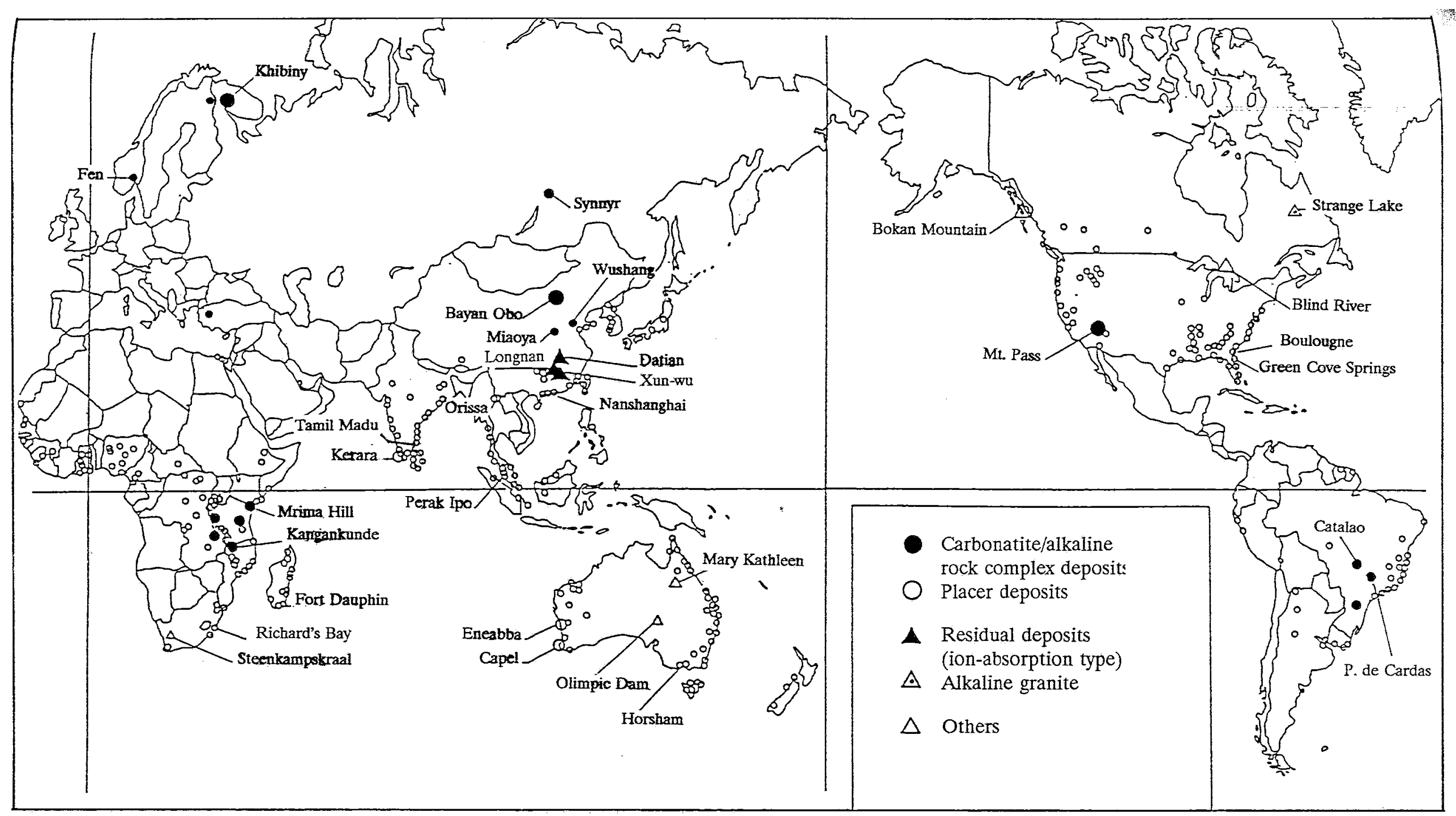

Figure 1. Worldwide distribution of rare-earth ore deposits. 


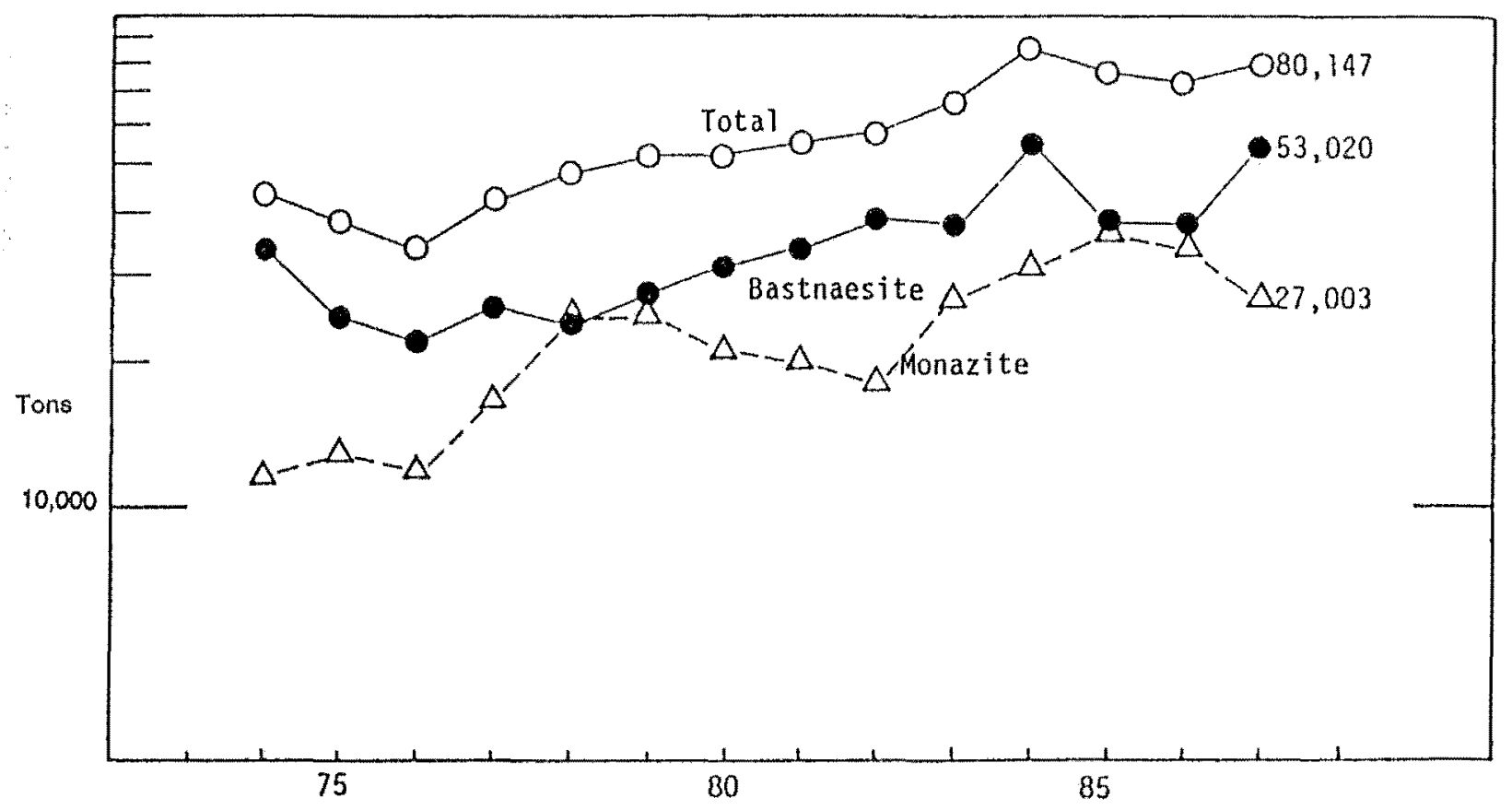

Figure 2. Total rare-earth mineral production. 


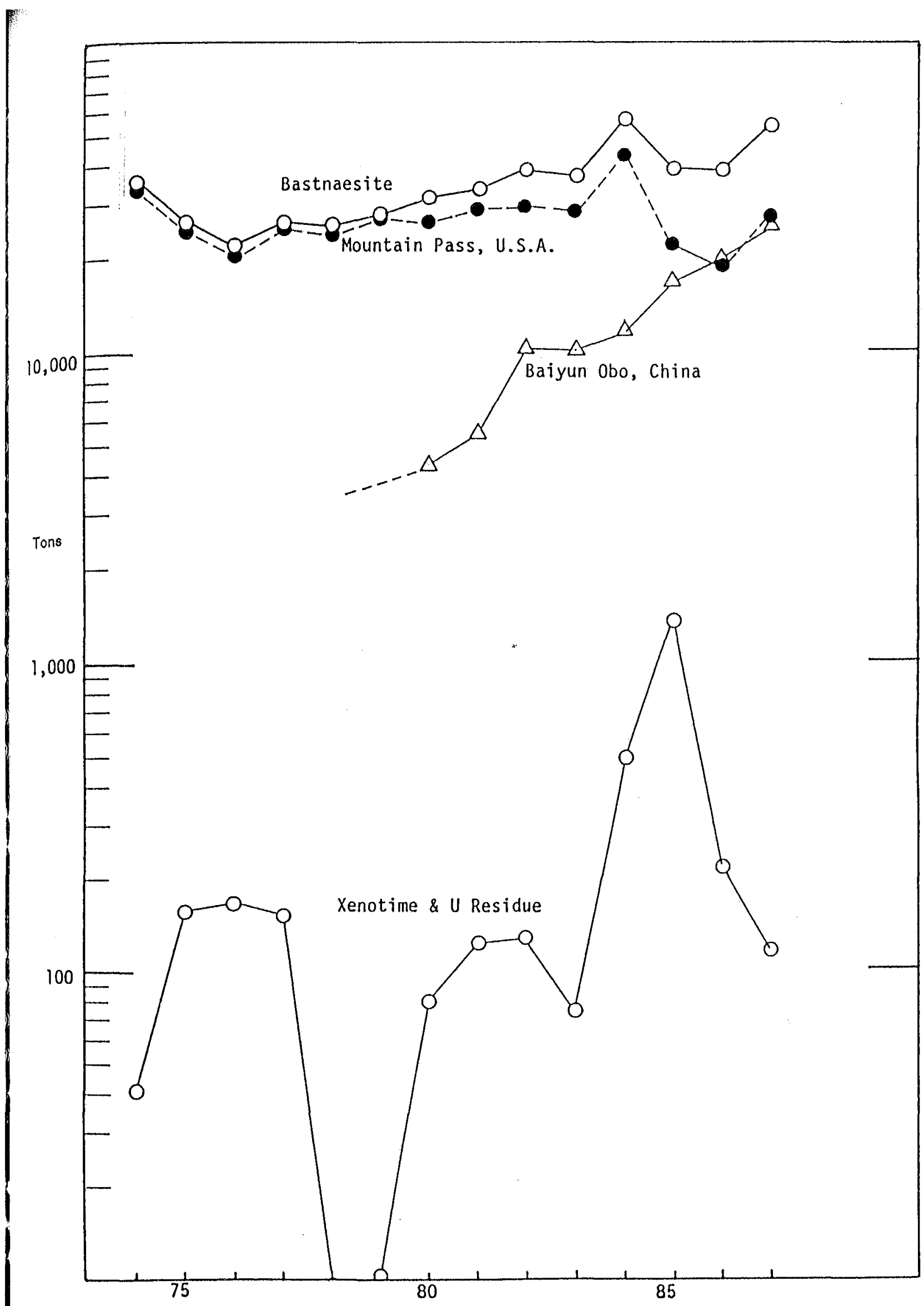

Figure 3. Production of bastnacsite and other rare earths. 


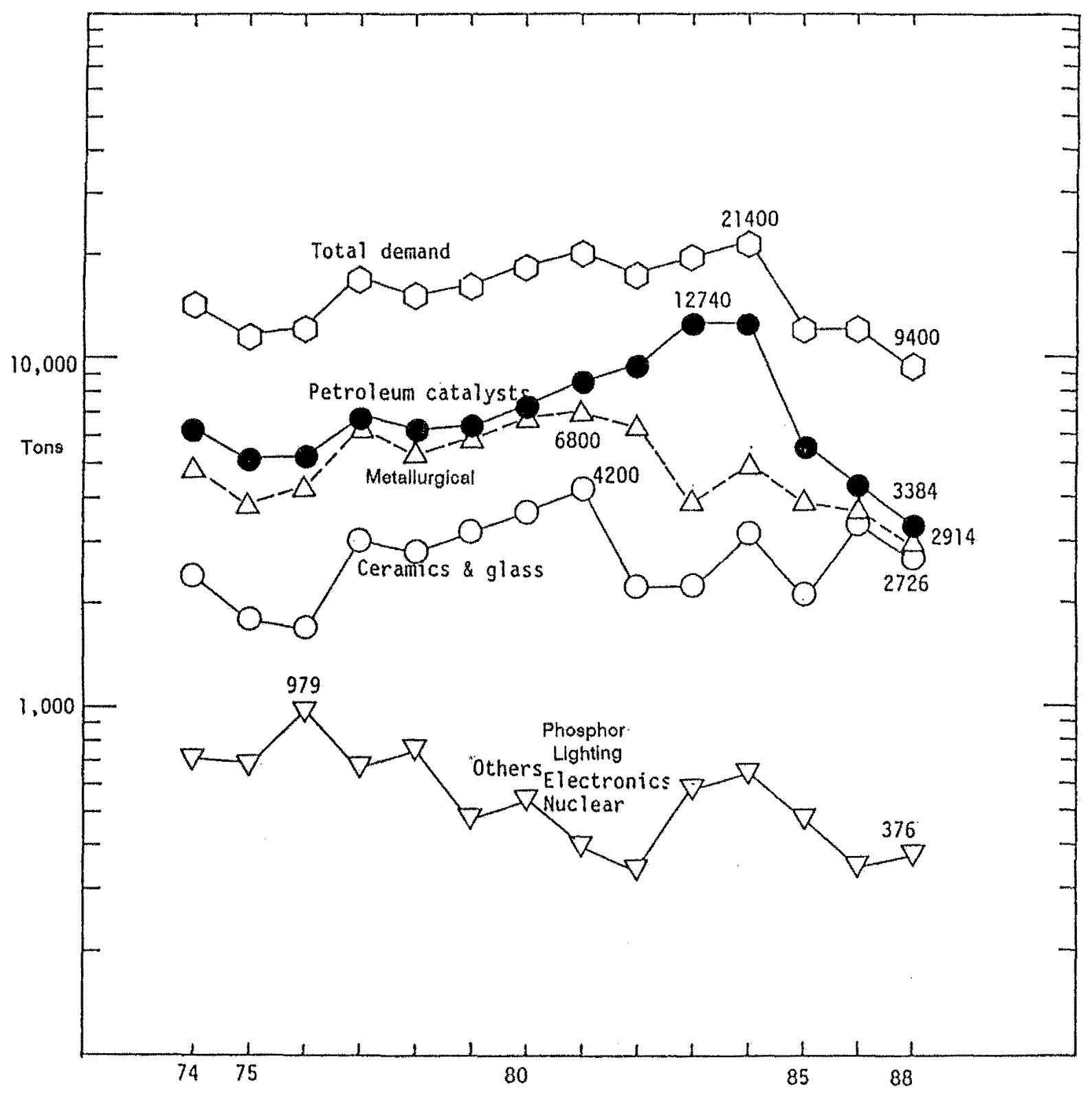

Figure 4. Demand for rare earths by endruse of United States. 


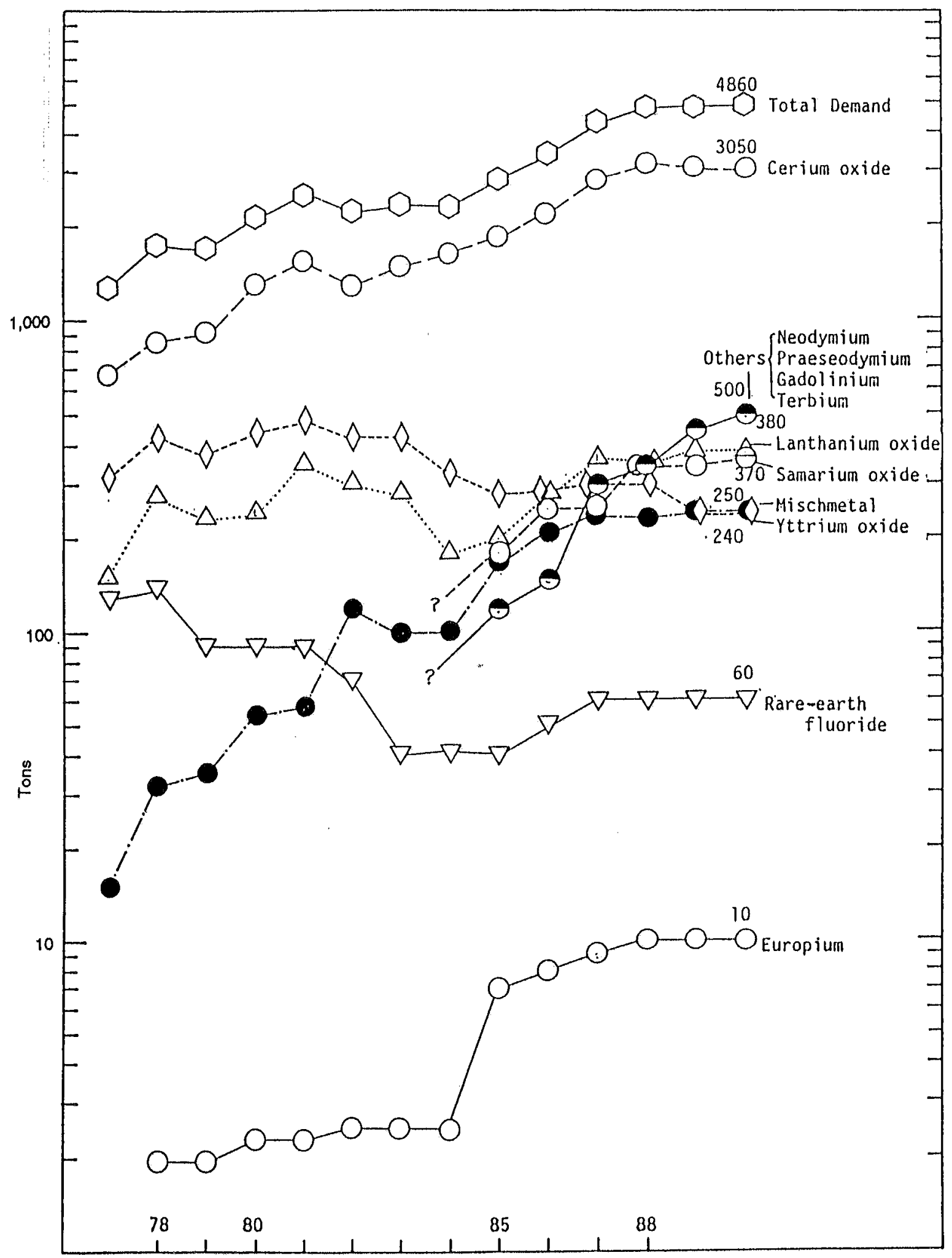

Figure 5. Trend of rare-earth consumption by Japan (1978-1988). 


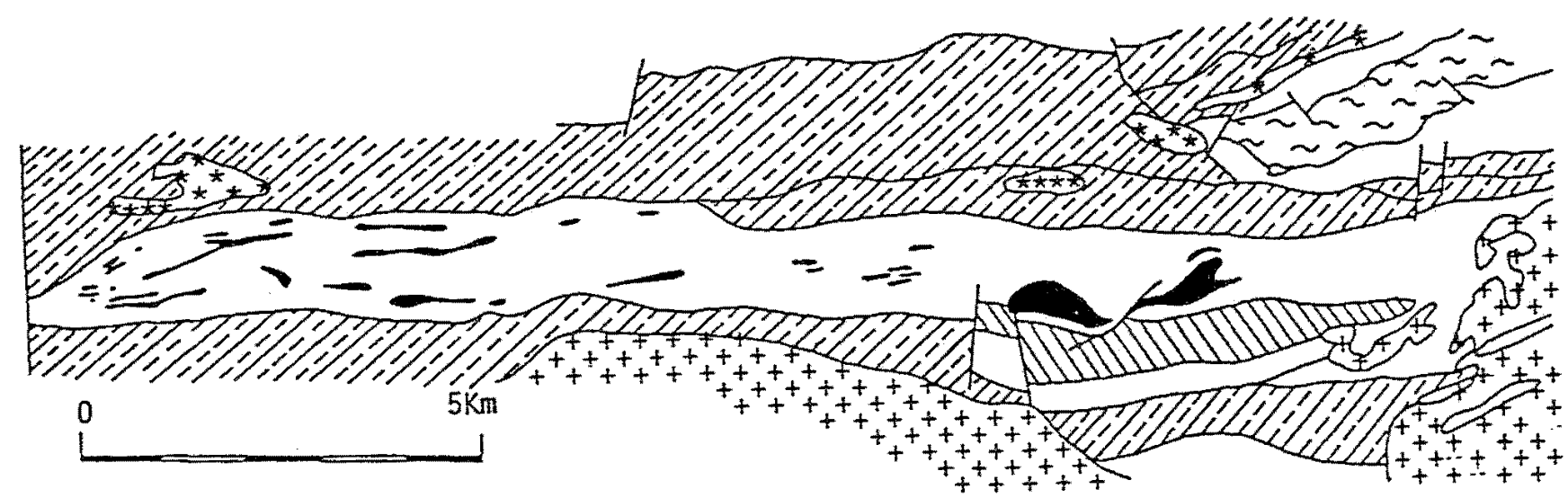

Geologic Map of the Baiyun Obo Iron Ore Deposits (Wan Zonggang 1973)

\begin{tabular}{|c|c|c|c|}
\hline$\frac{t^{+}+t^{+}+t}{t^{*} t^{*} t^{*}}$ & $\begin{array}{l}\text { Biotite granites } \\
\text { Gabbro \& diorite porphy }\end{array}$ & & \\
\hline & Slates & & \\
\hline & Dolomite \& Limestones & $\therefore$ E & \\
\hline bilita & Quartz sands \& slates & 虽出 & 5 \\
\hline$\because \because$ & $\begin{array}{r}\text { Quartz sands \& conglo- } \\
\text { merates }\end{array}$ & 范 & $\overbrace{\infty}^{\infty}$ \\
\hline & Archean system & & \\
\hline
\end{tabular}

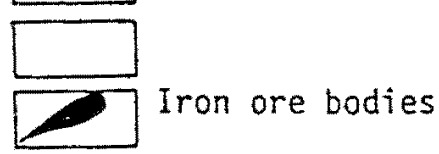

畜

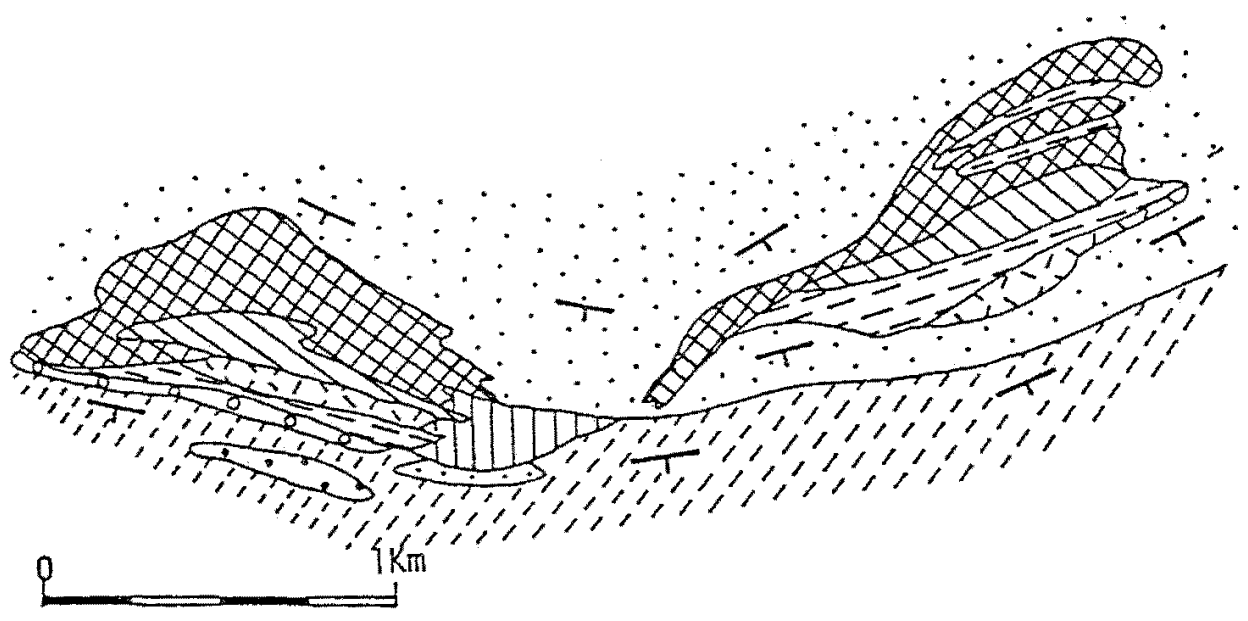

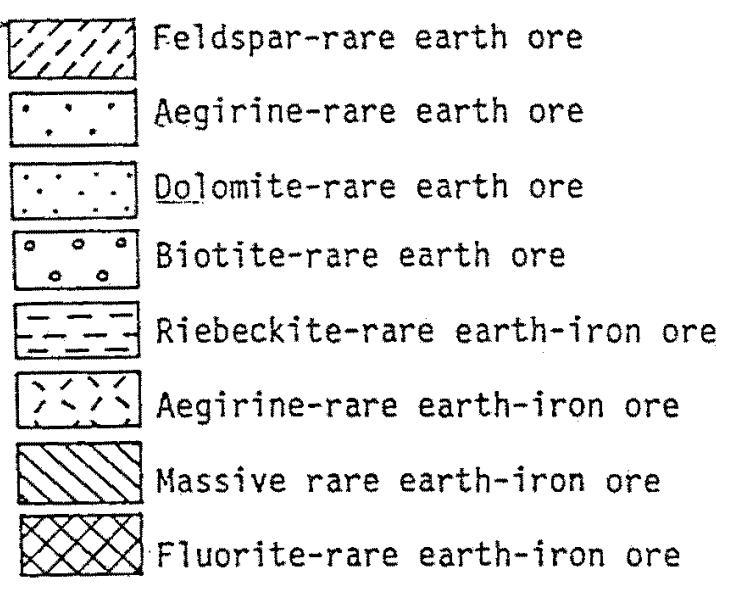

The occurrence of the Main ore body of Baiyun Obo deposit (Bai Ge \& Yuan Zhongxin 1985)

Figure 6. The occurrence of rare-earth-bearing iron ore deposits of Baiyun Obo Mine, China. 


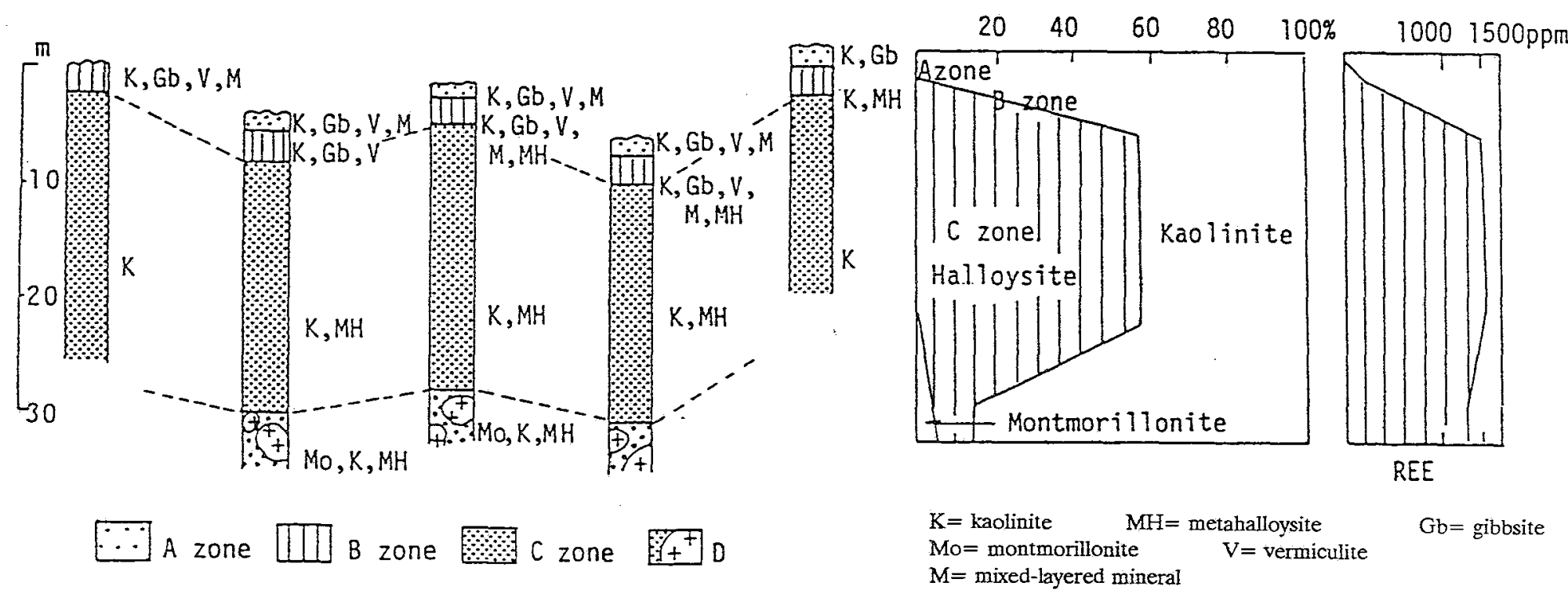

(Yang Zhunming 1987)

Figure 7. Schematic profile of weathering crust and rare-earth content of Longnan deposit. 

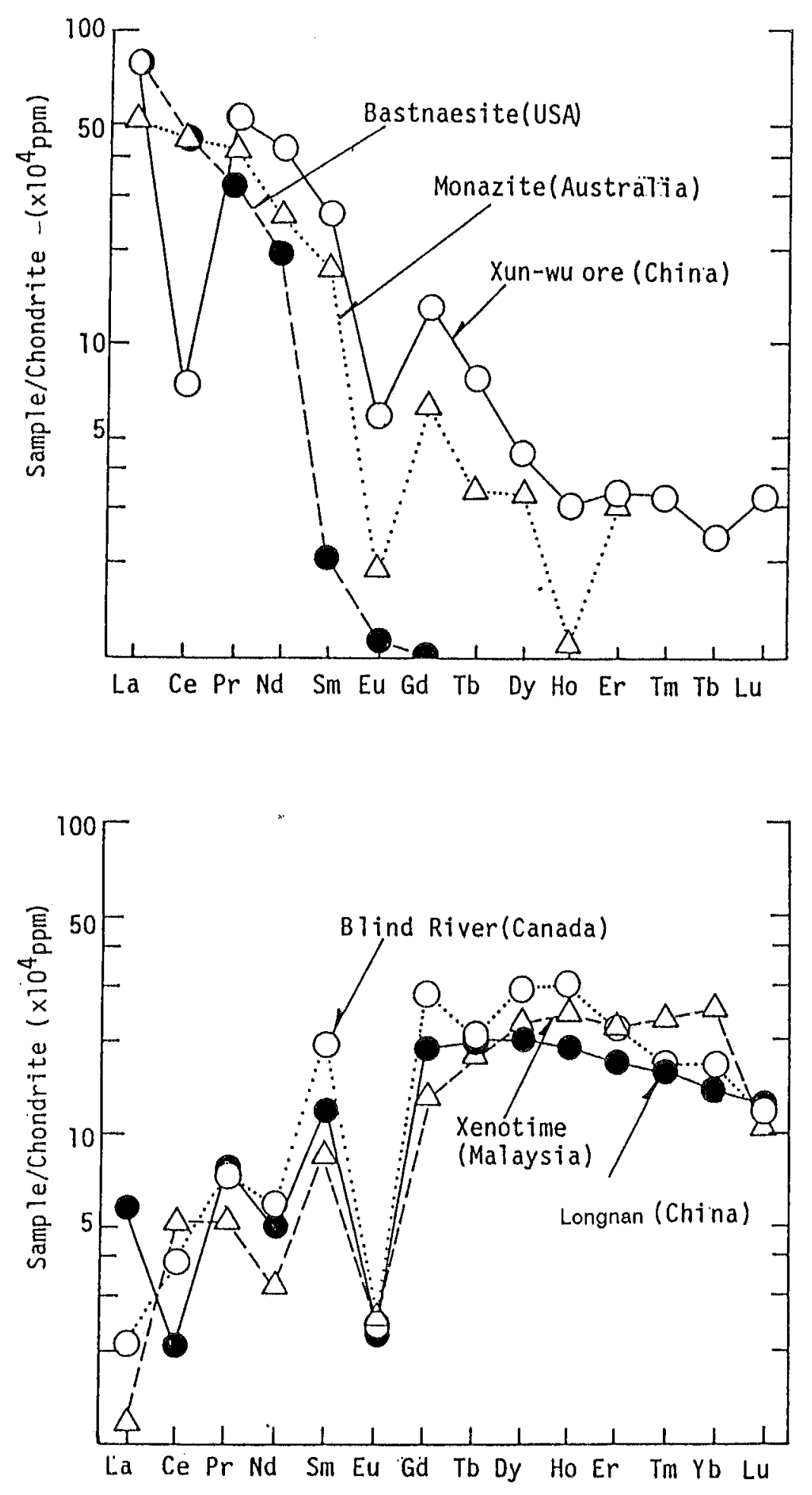

Figure 8. Chondrite normalized patterns of main rare-earth ores which serve to indicate abundance of individual rare earths. 

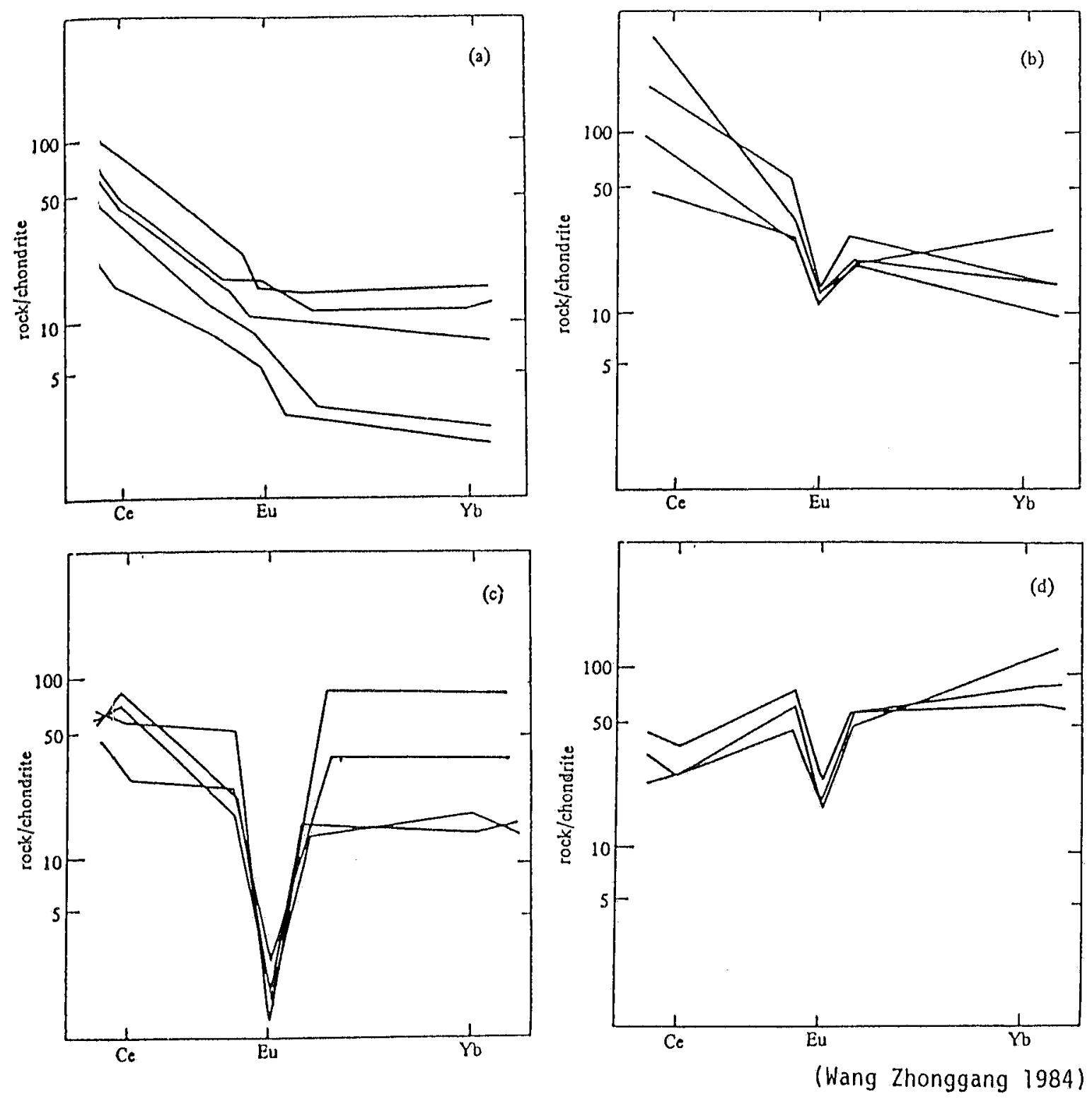

Figure 9. Chondrite normalized patterns of various granitoids in China which serve to indicate the relative abundance of cerium, europium, and yttrium. 


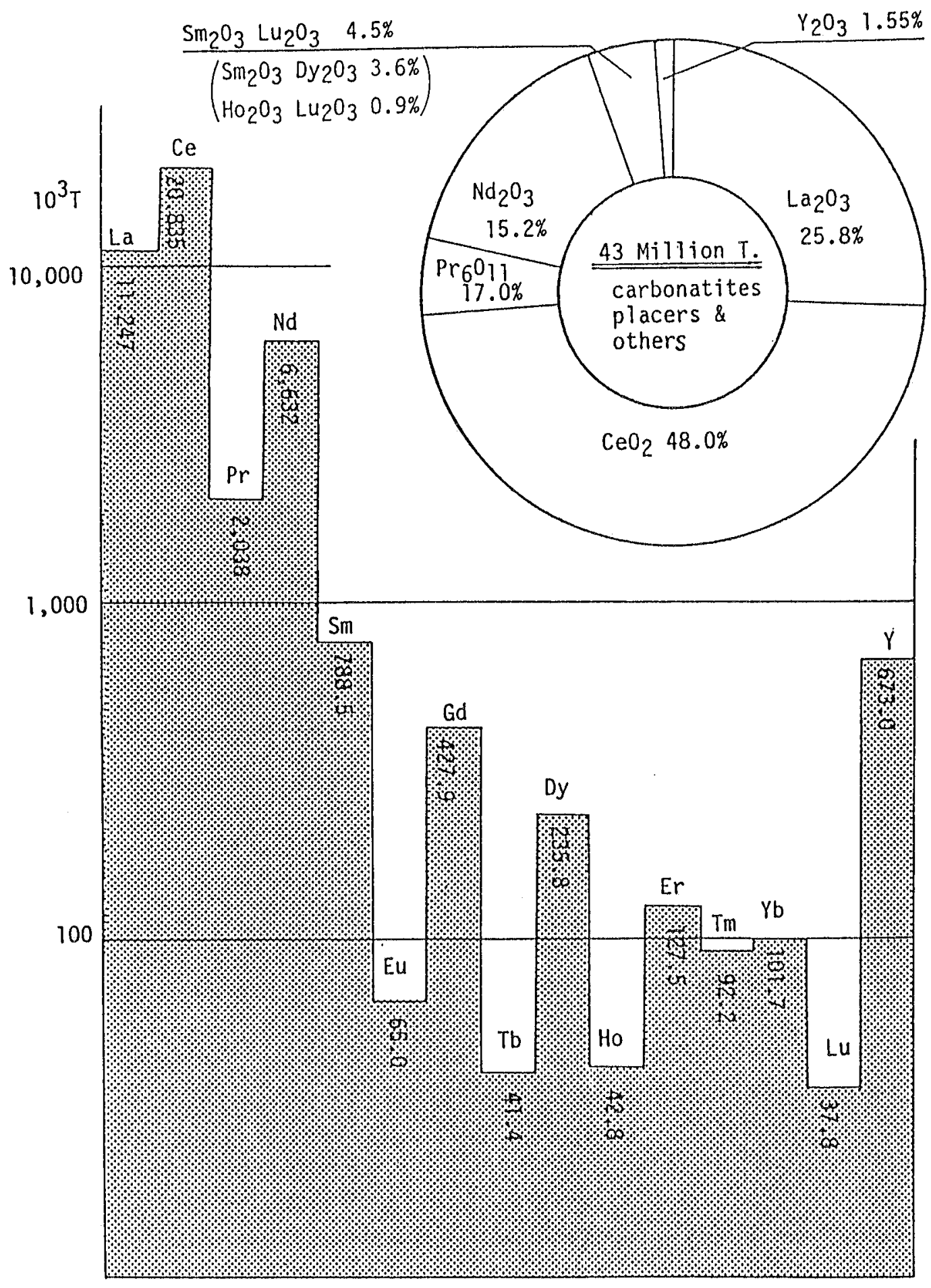

Figure 10. Balance of rare earths based on world reserve. 
recent rare-earth production abruptly decreased to 9,500 tpy due to diminished demand for petroleum cracking catalysts.

\section{Residual-Type Rare-Earth Deposits}

Residual-type rare-earth deposits are recently formed geologic deposits closely related to residual weathering crusts originating from granitoids. Weathering crusts are divided into four zones based on clay mineral assemblages (Figure 7). Metalalloysite-kaolinite zones, depleted in cerium but rich in other rare-earth elements, are exploited by open-cut mining.

There are also two types of chondrite normalized patterns (Figure 8); the pattern of the Long-nan deposit is very similar to that of xenotime, and the Xun-wu deposit is dominated by middle rare earths.

Generally, granitoids contain 150 to 200 parts per million (ppm) rare-earth oxides and show variable chondrite normalized patterns (Figure 9a). Diorite and tonalite commonly have a smooth normalized pattern, but more differentiated granites have a distinct right-hand inclined pattern (Figure 9b) with strong depletion of europium due to its partitioning behavior into calcium plagioclase at an earlier magmatic stage. Furthermore, some granites show a flat-like pattern with a remarkable negative europium anomaly (Figure 9c), and some granites have an unusual left-hand inclined pattern (Figure 9d). This extraordinary pattern is usually observed only in alkali-feldspar granites in South China.

\section{Problems of Rare-Earth Resources}

Problems of rare-earth resources are 1) the imbalance of supply-and-demand trends for each rare-earth element, and 2) locating and developing new rare-earth deposits to balance present and future demands. Based on total world reserves and resources (Table 1) and present consumption, there should be no anxiety over future supply. World reserves and resources of rare-earth oxides are more than 1,000 times present world consumption.

As explained previously, almost all reserves are from two huge carbonatite deposits (Baiyun Obo and Mountain Pass) -- bastnaesite and monazite. This means $94 \%$ of reserves predominate in light rare earths (Figure 10), while the remaining $6 \%$ contain middle to heavy rare earths including yttrium. Only $0.9 \%$ of the reserves contain heavy rare earths (holmium to lutetium). Almost all ore deposits developed so far are rich in lanthanum and cerium, depleted in middle to heavy rare earths, and abnormally scanty in europium, terbium, holmium, and lutetium. Increasing demands for middle rare earths are anticipated due to new and recent developments in high-tech industries including electronics. Almost all lanthanum and cerium are stockpiled as surplus, but costs for middle to heavy rare-earths are predicted to rise sharply.

Recommendations for resolution of these problems would include:

1) Fundamental research for new types of ore deposits, such as weathering crusts on granitoids which contain relatively large amounts of middle to heavy rare earths. Alkaline granites and alkaline rocks are usually rich in heavy rare-earths and yttrium. 
2) Development of technology for recovery of rare earths from such mineral and residue materials as apatite, zircon, and red muds of aluminum smelting.

3) Increased efforts to meet new demands for light rare earths (especially lanthanum and cerium) to stabilize the cost of whole rare-earth products. 


\title{
Industrial Uses and Future Demand for Rare Earths
}

\author{
Dr. Barry Kilbourn \\ Unocal/Molycorp \\ White Plains, New York
}

Editors' Note: The text of the author's taped address was edited from a copy transcribed outside these offices. Editors assume no responsibility for errors or omissions in transcription and have relied on the assistance and advice of the authors and technical experts for technical corrections.

This is our special biased version of the periodic table in Figure 1. It gives the correct answers to the various elements we're going to consider. I will also clarify some points of nomenclature. When we use words such as lanthanoid, lanthanide, lanthanum, to what exactly are we referring? The International Union of Pure and Applied Chemistry (IUPAC) rules (Figure 2) are the definitions which I will use on lanthanides and yttrium. For my purposes, "lanthanides" will refer to the group of rare earths as a whole between atomic numbers 57 (lanthanum) and 71 (lutetium). A "lanthanide" is a single rare earth member of this group. Dr. Gschneidner also used other general terms, such as "lights" and "heavies" referring to light and heavy rare earths, atomic numbers 57 to 64 and numbers 65 to 71 , respectively.

Additionally, the boundary location between gadolinium and terbium (Figure 3) is somewhat arbitrary. This is a very recent slide, as you will deduce, because of two elements that have just come into prominence. In letters to various journals, people have said we now can replace those rare and expensive elements, or rare earths, with elements that are readily available.

With the emphasis on the differentiation of elements within the series, Figure 4 shows the odd and even atomic numbered elements and their comparative abundance. Bear in mind there are more evens than odds. If marketplace demand is for odd-numbered elements, we're still going to have an abundance of even-numbered elements. We have processes to selectively extract the odd-numbered elements. Although supply occurs in this natural ratio, commercial market demand very rarely occurs in this ratio.

Bastnaesite, monazite and xenotime are the three main minerals which supply rare-earth elements (Figure 5). Regardless of the ore, cerium is the material in demand and has a lot of markets. In 1986 worldwide production of these three main rare-earth ores reached 600 tons for xenotime, 20,000 tons for bastnaesite, and 23,000 tons for monazite (Figure 6). Weight here is given in terms of the amount of lanthanide oxide contained in the ore. This is usual practice which avoids the confusion of designating whether the ore is a fluoride or a phosphate, and so forth. There is almost 100 times as much bastnaesite and monazite processed in the world compared to xenotime -- 43,000 tons compared to 600 tons. But 600 tons of xenotime contains 350 to 400 tons of yttrium oxide, while yttrium oxide is only $1 \%$ (2000 tons) of the production of the other lanthanide oxides in bastnaesite or monazite. These ores contain primarily cerium oxide, lanthanum, and smaller amounts of the remaining rare earths of the lanthanide series.

Reviewing production aspects of the materials (Figure 7), we need to consider where rare earths occur, how they are processed, their applications, and what rare-earth properties are desired. Ore is processed to produce concentrates (see Figure 8, flow diagram) which are 
sold as materials in the form of mixed lanthanides or pure lanthanides which are then consumed by other processors or used directly by various industries. Concentrates can also be converted into mixed lanthanide metals.

We've heard mention of mischmetal. On a commercial scale it requires solvent extraction; on a small scale the ion exchange method is used for some heavy rare earths. The amount of heavy rare earths in mischmetal is very small compared to lights. The dominant process will be solvent extraction technology.

Rare-earth elements in solution can be produced at a reasonable purity which can be converted to a solution of salt or, most usually, to the oxide. Because of its high acidity and high stability, a lanthanide oxide is an ideal material for colors. It can also be converted to pure metals or marketable materials. The lanthanide industry will produce a range of products including mixed materials as metals and concentrates and pure materials as compounds, metals, and oxides.

The commercial application and value of these materials relate directly to their properties. A particular application might require a property unique only to lanthanides which are not very easily replaced by other materials. On the other hand, if the desired property may be achieved by many other materials, the question of production cost becomes important when competing materials are inherently much cheaper than lanthanides.

Dr. Gschneidner also mentioned $f$ electrons which are the basis of very special spectral behavior. There is a growing interest in applications for magnetic properties of lanthanides, but there is competition from other elements. Quite a few other elements form very stable oxides. Figure 9 indicates the magnitude of their affinity for oxygen. Consequently, there is competition in the use of oxides. Consider, for example, the use of calcium in steel production. You will see one or two applications in which cerium's oxidation ability is crucial. There are other oxidants which can be similarly used creating competition between the use of cerium and other materials. In almost all these applications there will be competition between the lanthanides and other elements.

Applications can be divided into four groups (Figure 10): chemicals and catalysts, metals and alloys, ceramics and glass, and phosphors and electronics. Pure oxides or pure metals are required for some applications. For other uses, concentrates and mixed compounds are quite acceptable and create a large market because of their lower prices.

The use of rare earth in metals applications (Figure 11) is clearly divided between those requiring only mixed lanthanide metal (derived from the lower-priced concentrate) or some highly pure individual metals with some very special properties. Mischmetals are used in iron and steel production in large quantities. The purer metals shown at the bottom of the figure also have lower consumptions, Individual pure elements are used in superalloys. Neodymium oxides go into magnets with some exotic uses of certain special metals. Magnet alloys also can use concentrates. Terbium and gadolinium are used in special applications in magneto-optics and electronics.

Figure 12 shows the proportions of end use of lanthanides and yttrium each year within the four groups between 1969 and 1985. The upturn in 1972 is directly related to Alaska; the high volume of mischmetal used in high-strength, low-alloy steel production was crucial for the integrity of the Alaska pipeline. Technology introduced the use of mischmetal to 


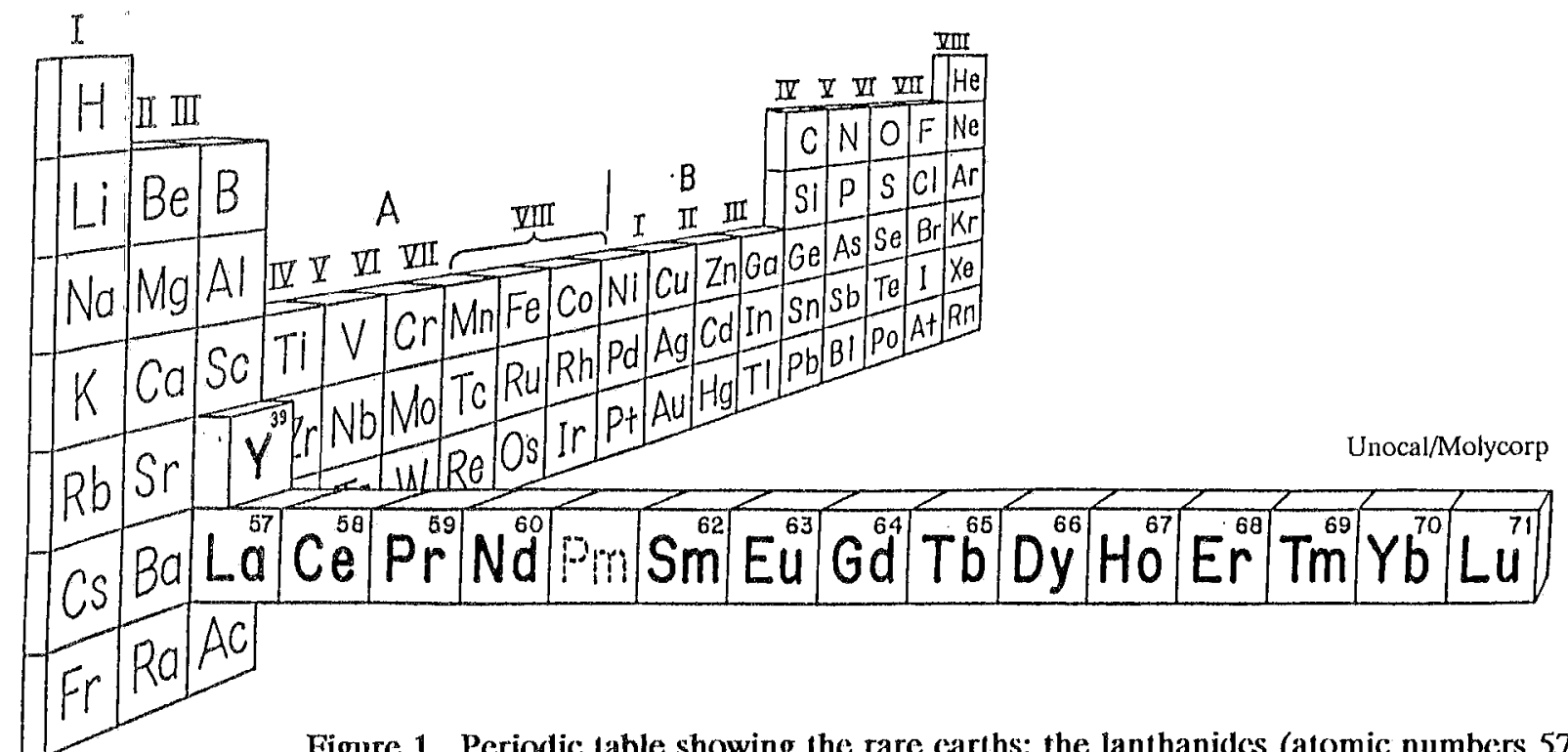

Figure 1. Periodic table showing the rare carths: the lanthanides (atomic numbers 57-71), and yttrium (39) and scandium (21).

Rare-Earth Metals Scandium, Yttrium and Lanthanum, 57, to Lutetium, 71

Lanthan-oids

or

Cerium, 58, to Lutetium, 71

Lanthan-ides

Lanthan-ons

Lanthan-oids

Lanthan-ides plus Lanthanum

according to practice

Lanthanides Lanthanum, 57, to Lutetium, 7]

Unocal / Molycorp btk $9 / 87$

Figure 2. Nomenclature of rare earths according to IUPAC rules. 
La $\mathrm{Ce}$

Unocal / Molycorp btk $10 / 87$
LIGHTS

$\operatorname{Pr}$

$\mathrm{Nd}$

(Yttrics) (Pm) $\mathrm{Sm}$

(Cerics)

(Cerics)

Figure 3. Division of rare-earth lanthanides into a "light" and a "heavy" group with the dividing line between gadolinium and terbium.

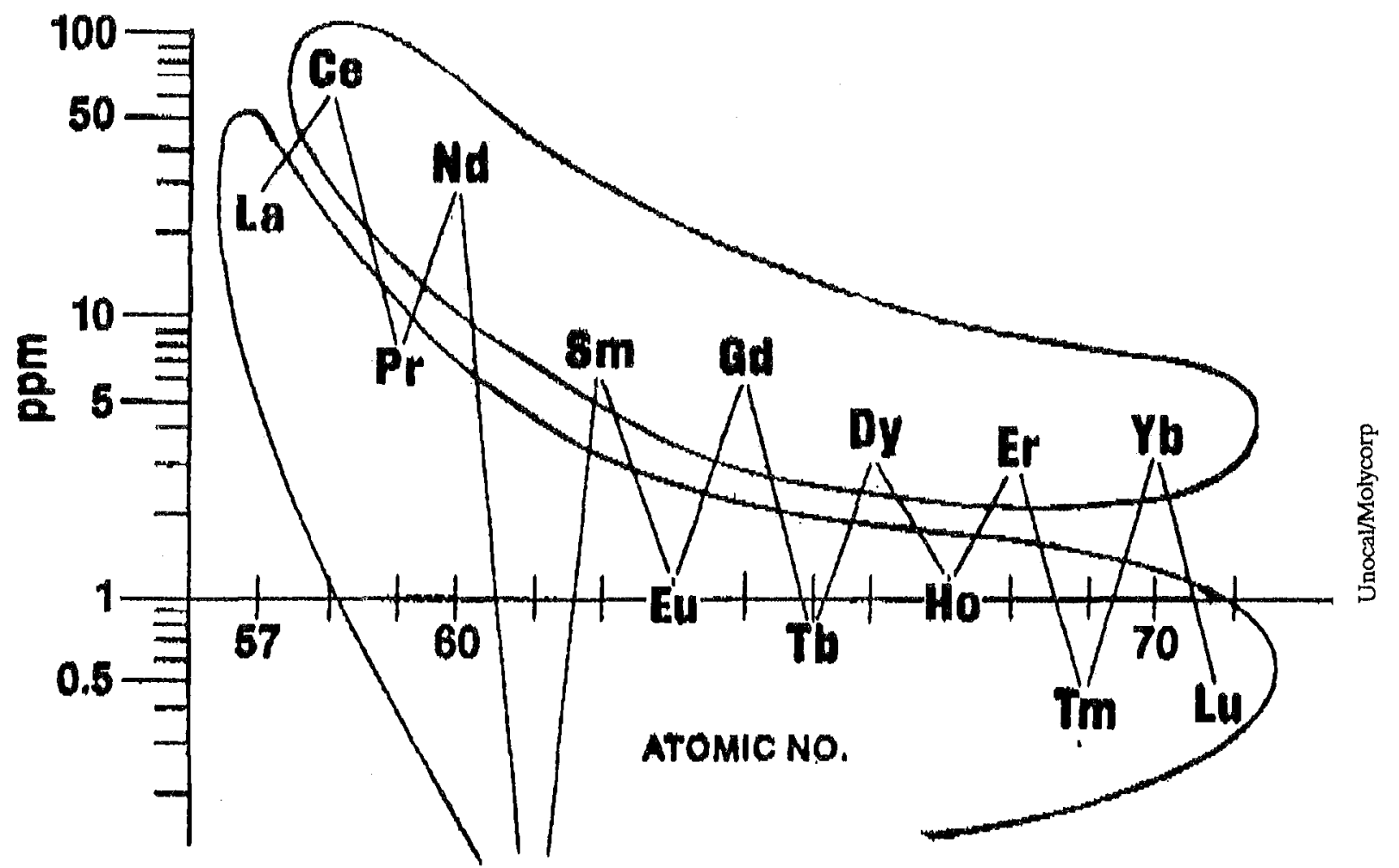

Figure 4. Relative abundance of lanthanides in the earth's crust plotted according to atomic number. Note the greater relative abundance of even-numbered elements. 


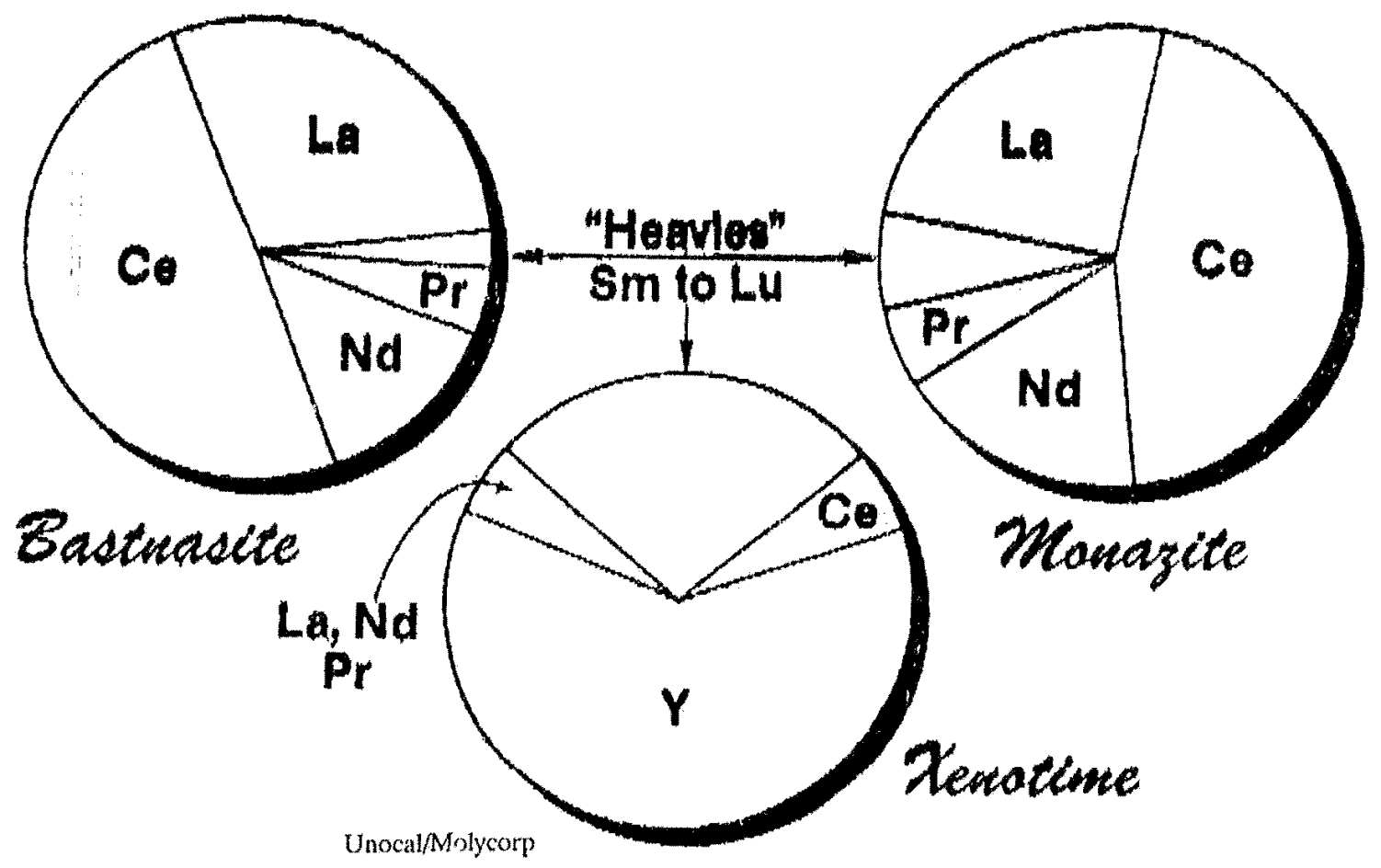

Figure 5. Content of principal rare earths: cerium, lanthanum, yttrium, neodymium, and praseodymium in the three main rare-earth ores.

\section{-. Bastnasite 20,000 \\ -.. Monazite 23,000 \\ $\cdots \quad$ Xenotime 600 \\ Unooal / Molycorp btk $7 / 8 B$}

Figure 6. 1986 annual production (tons) of the three main rare-carth ores. 
OCCURRENCE

PRODUCTION

APPLICATIONS

PROPERTIES
Where they come from

How they are made

What they are used for

Why they are used

Figure 7. Basic questions to understand the industrial aspects of lanthanides.

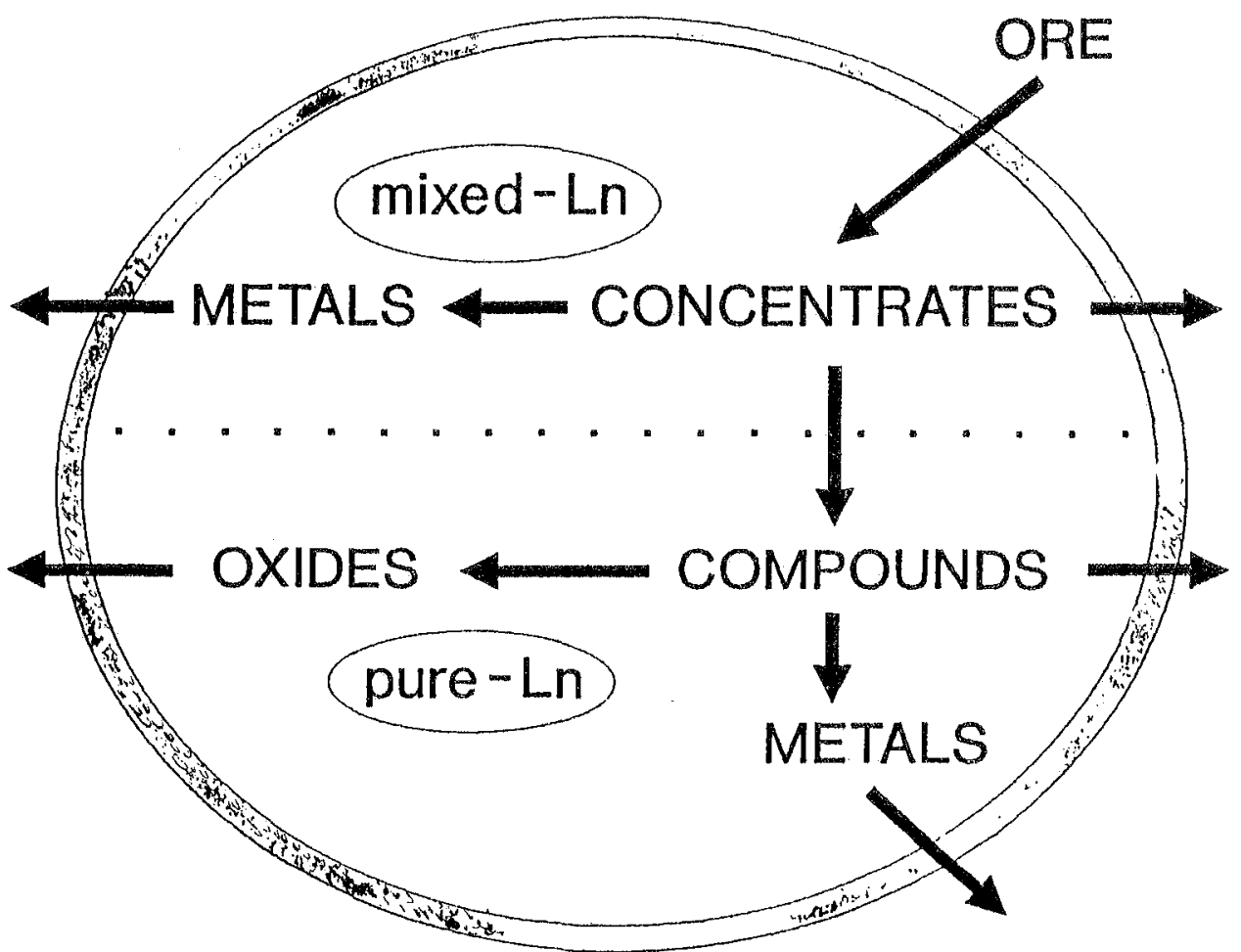

Unocal / Molycorp btk 8/88

Figure 8. The progression from ore to concentrates, compounds, oxides, and metals. 
improve sulfide shape control and corrosion resistance within the pipe metal. After 1973 the metals usage proportion drops as consumption of mischmetal and steel declines. This was due to 1) a glut on the steel market; 2) competitive technologies for making purer steels which no longer require lanthanides to bond sulfides; and 3) competing processes which utilize calcium and magnesium instead of lanthanides in iron and steel production. Rare earths used in manufacture of catalysts has tended to grow, but with some reductions. The reason is that oil prices rose due to the shortage of crude oil creating a desperate demand particularly for gasoline in the U.S. Gasoline production is a major market for our materials since large amounts of lanthanides go into cracking catalysts.

The bulk of rare-earth applications is as concentrates. Any dip in concentrate production because of market demand has implications in production and availability of all concentrates. For example, production of samarium depends on production of lanthanum concentrate.

The divisions of four main use areas and the variety of objects made, either using lanthanides or containing lanthanides, is shown again in Figures 13 and 14. For example, wheel rims made from high-alloy steels use lanthanide mischmetal as do cast irons of various kinds and shapes. Lanthanide mischmetals and various cerium-containing alloys are used for their particular properties of graphite crystallite shape control which contributes to the properties of cast irons. Also tape drive mechanisms and headphones use magnets composed of samarium, cobalt, or neodymium. Alloys containing lanthanum or nickel readily absorb hydrogen, so you can make a lighter hydrogen-containing cylinder. This is one of the future growth areas for lanthanum materials.

Mischmetal (lanthanides) is used to produce iron and steel to allow it to bend without cracking. Inside the steel, sulfides (most probably manganese sulfides) are strung out to form lines of weakness. But if you add lanthanum and cerium contained in the lanthanide mischmetal, rare earths combine with the impurities to make oxysulfides. The sulfides then no longer form lines of weakness, so the metal can be bent with no problem.

In small cast-iron parts, lanthanides are used to control crystallite growth of graphite which is a crucial drawback in casting any iron. They modify the morphology of graphite from a flake to a sphere and eliminate lines of fracture. There are various crystal shapes (dovetail, vermicular), all subtly dependent on the graphite crystallite growth. It has been found that additions of lanthanides can control that crystallite growth.

Figure 13 lists superalloys made with lanthanum, yttrium, and cerium. Most of you probably came here by aircraft. The alloys that line the back of the jet turbine, which is exposed to very, very hot exhaust flame, are often superalloys made even more "super" by a pinch of these lanthanides. These and similar alloys improve stability at very high temperatures. Yttrium oxide is used in a process known as mechanical alloying. The resultant very fine dispersion of these oxides in the metal strengthens its behavior at high temperatures, such as turbine vanes.

New aluminum alloys containing cerium are being developed but are not yet available for major commercial use. These alloys are being made by rapid solidification and, because of its very high affinity for oxygen, cerium forms very, very small oxide particles that give the metal strength. Conventional aluminum alloys can only withstand temperatures of $150^{\circ} \mathrm{C}$ to $200^{\circ} \mathrm{C}$, while the addition of cerium enables the resulting allow to work at much higher temperatures. 
Neodymium and samarium are no longer the only rare earths used in magnets (Figure 15). The lanthanides have unique magnetic behavior and are special on the periodic table. It is most unlikely they would be replaced by another element outside the lanthanide series, but within themselves it is possible for samarium to be replaced to some extent by neodymium. There are samarium-cobalt magnets and neodymium-iron-boron magnets, and other elements are being used as additives. Dysprosium, for example, can act either in oxide form or as a metal in the neodymium-iron-boron magnet system to improve its properties. Magnetic strength is the property crucial to any practical use of magnets. If you remember the rules of abundance from before, praseodymium is more abundant than samarium; you can make a praseodymium-cobalt system that has comparable properties. So, if samarium is in short supply as is the case now, praseodymium can replace samarium and, in fact, is currently being considered.

Lanthanides can form stable intermetallic compounds with materials normally considered impure elements, such as lead in cast iron. By adding a mischmetal, the lanthanides tie up the lead and other trace elements that otherwise would cause problems. There are various other applications, such as hydrogen storage or power sharing and capturing hydrogen from gas process streams.

One new area is an intermetallic in an enclosed battery system. In a nickel-cadmium battery it is possible to substitute a lanthanum-nickel intermetallic; the hydrogen is absorbed, and the lanthanum-nickel system has a much higher rechargeability than the standard nickelcadmium battery. Instead of a 24-hour charge, only an hour is necessary. Neodymium in certain high-performance magnesium alloys creates a stable neodymium-magnesium intermetallic compound giving magnesium better performance at higher temperatures.

Production of catalysts for gasoline production is still the major consumer of lanthanides as a single application area (Figure 16). Another application in automobiles is in emission control devices. Over the next five or ten years Europe, and possibly the U.S., is going to have extensive auto emission controls. Cerium oxides and some lanthanum oxides will be used in these devices.

The cracking catalyst for producing gasoline is very fine white powder consumed worldwide on the order of a thousand tons per day, the largest commercial consumption of rare earth. The other major application for lanthanides is a ceramic monolith in your car's catalytic converter. It can either be in a honeycomb form or in the form of small pellets in a bed. Designed five or six years ago as pellets, it has now been replaced by the honeycomb monolith, a somewhat porous ceramic with a rough surface. To make catalysts the oxides are loaded onto that rough surface. One of the catalysts that helps make ethylbenzine into styrene contains cerium. Similarly, certain catalysts which help shift the equilibrium point of gas reactions and ammonia reactions use cerium. The cracking reaction breaks down the molecules that give you a smaller faction of gasoline. This is the major market for lanthanides at the moment. It is a market which can utilize either a concentrate, a mixed lanthanide in a fully natural mixture, or a cerium-rich mixed lanthanide material. Lanthanides give stability to the catalyst particularly at high temperatures necessary in an automobile because quite often the catalyst gets clogged with carbon that has to be burned off.

Lanthanides may be imported either as a mixed chloride or as a lanthanum concentrate. Lanthanide is used because it is a stable, relatively large, triangular ion needed in a zeolite. 


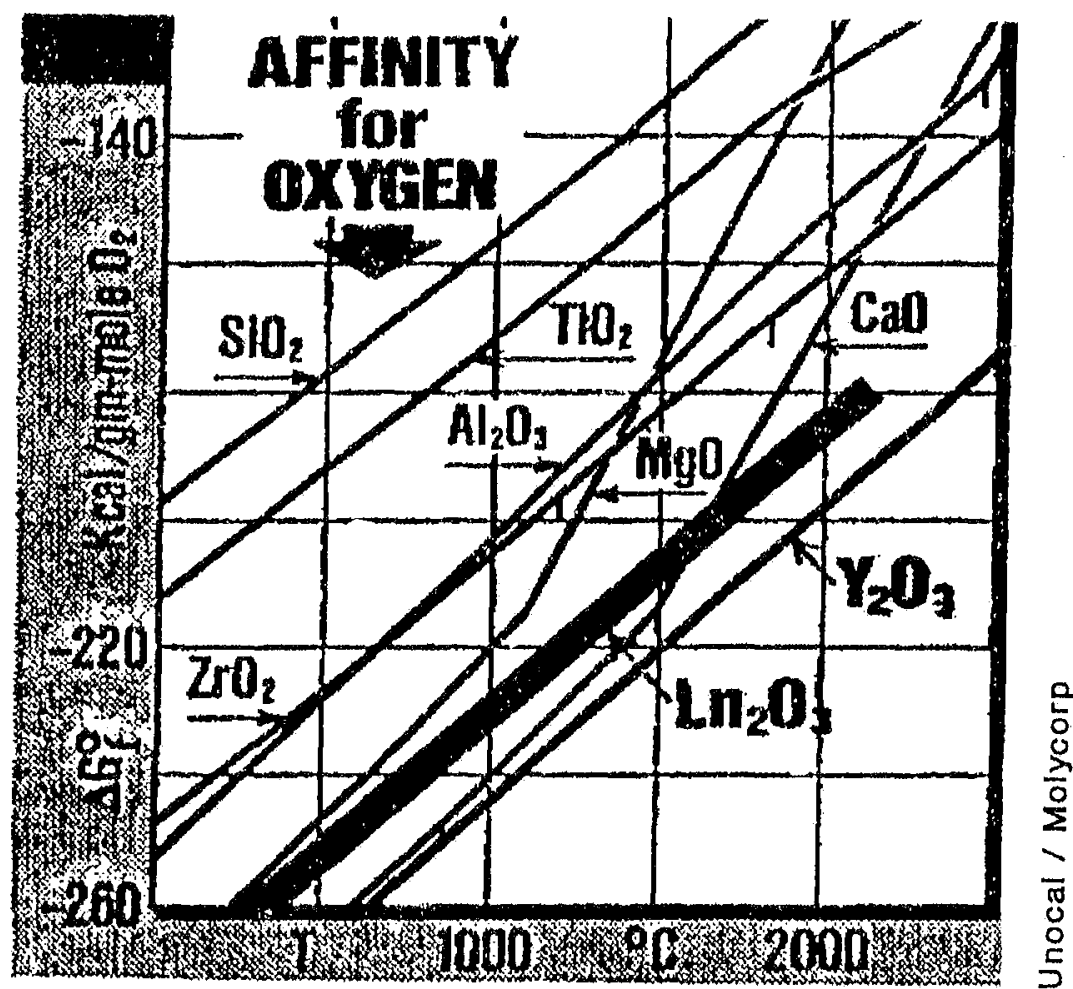

Figure 9. Free energy of formation of oxides of various elements. The plot indicates stability with respect to oxide formation.

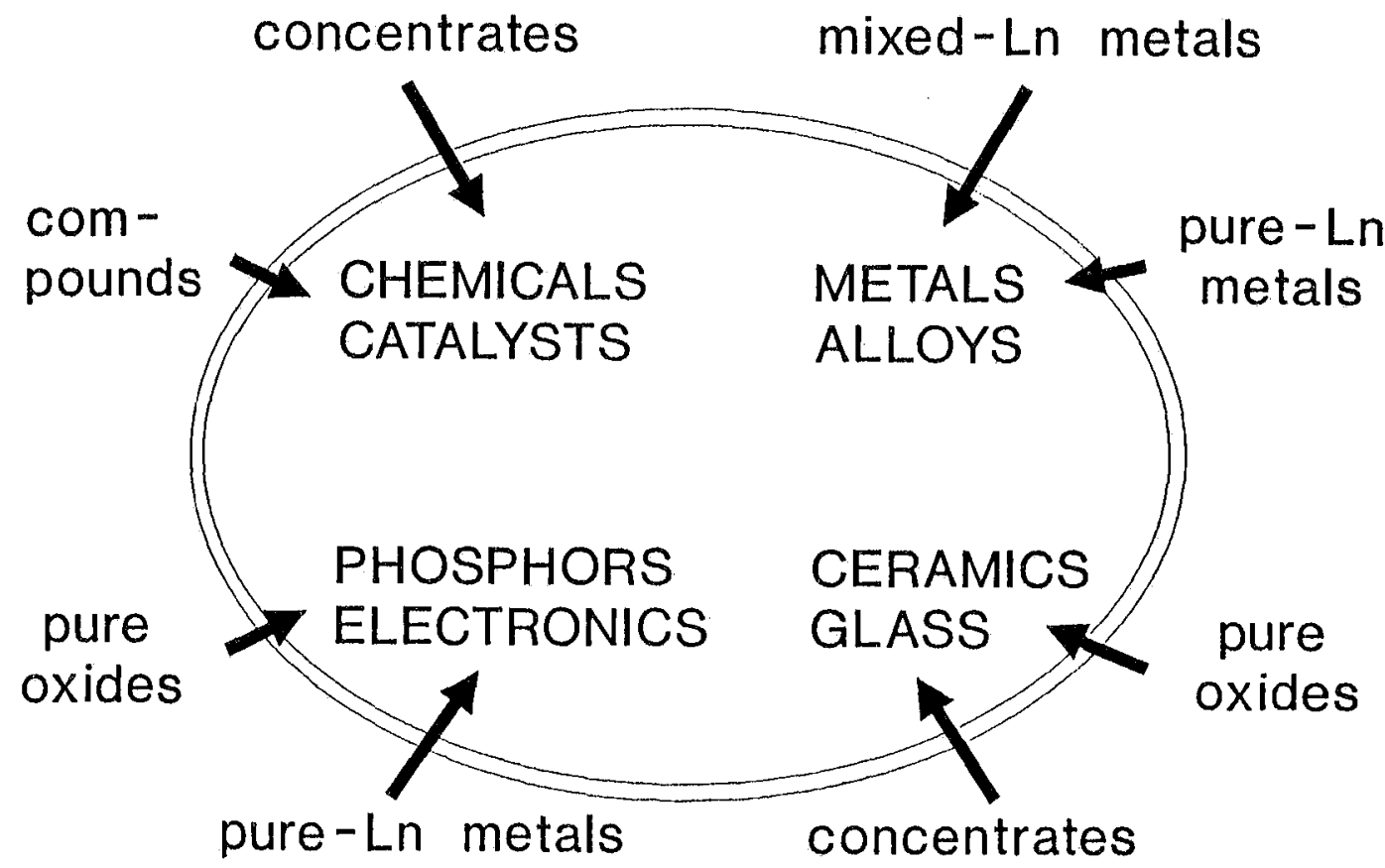

Unocal / Molycorp btk $8 / 88$

Figure 10. Four main areas of rare-carth applications and the rare-carth forms used in cach application. 


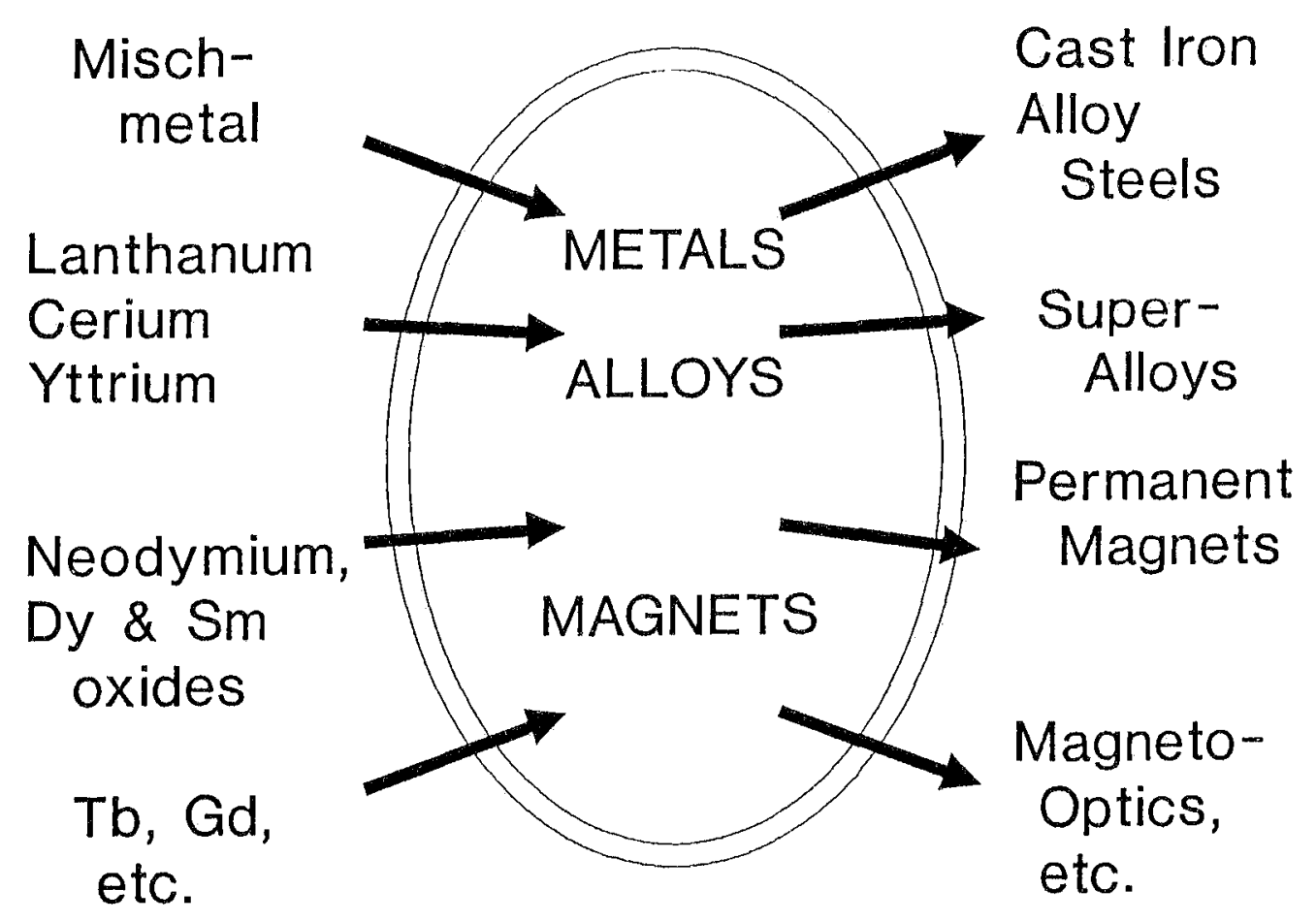

Unocal / Molycorp btk $8 / 88$

Figure 11. Uses of lanthanides in metallurgy.

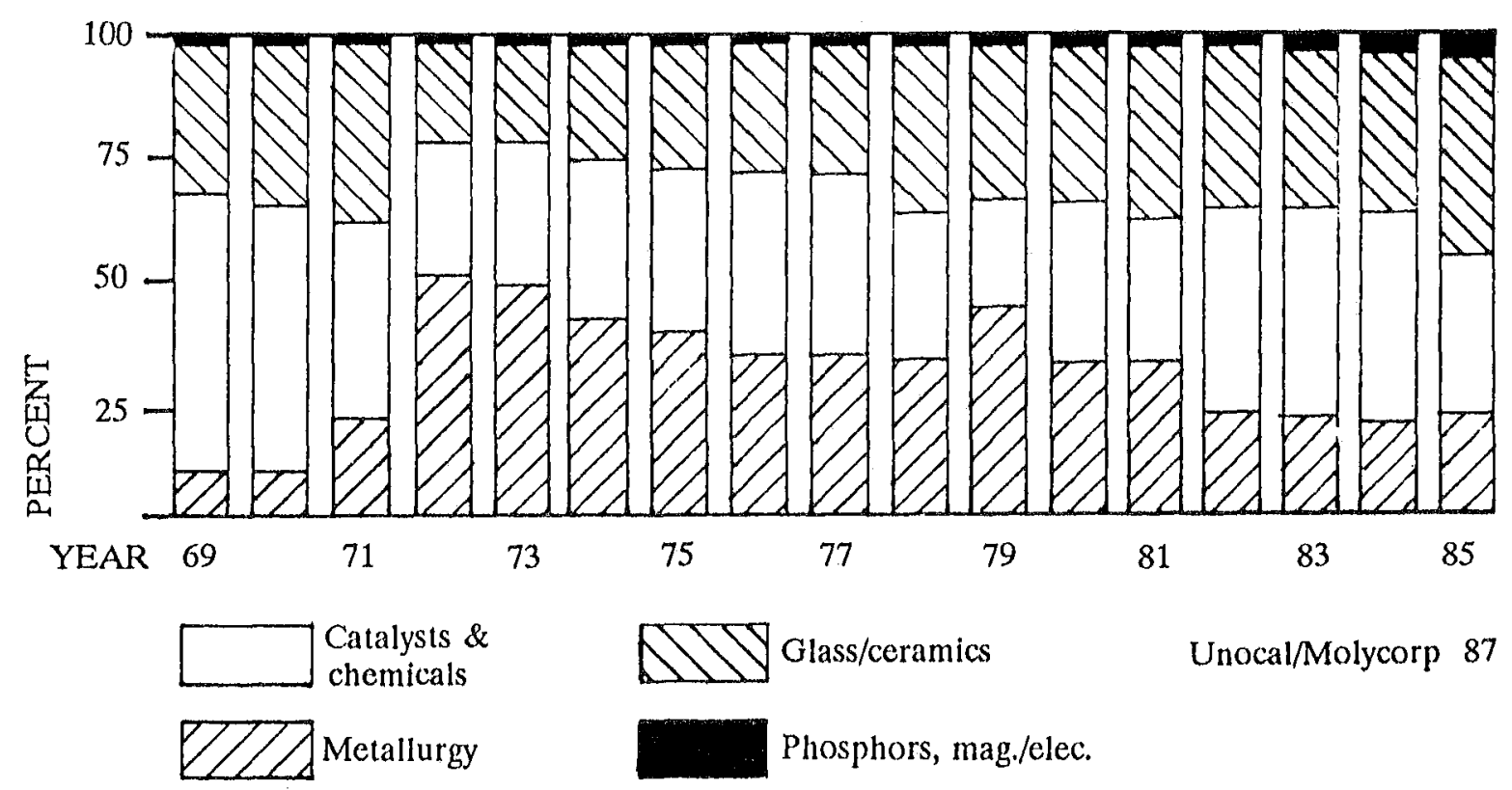

Figure 12. Lanthanide and yttrium consumption by tonnage in major application area. 


$\begin{array}{ll}\text { Mischmetal } & \text { Cast Iron } \\ & \text { HSLA Steel } \\ \text { Lanthanum } & \text { Super-alloys } \\ \text { Cerium } & \text { Pyrophoric alloys } \\ & \begin{array}{l}\text { RS Aluminum alloys } \\ \text { Super-alloys }\end{array}\end{array}$

Erbium

RS Titanium alloys

Yttrium

( ODS ) Super-alloys

Oxidation Resistant alloys

Unocal / Molycorp blk 10/87

Figure 13. Applications for lanthanide melals which depend on oxygen and sulfur affinity.

$\begin{array}{ll}\text { Mischmetal } & \begin{array}{c}\text { Cast Iron, } \\ \text { Graphlte Growth Control }\end{array} \\ \begin{array}{c}\text { Heavy Ln's } \\ \text { Mischmetal }\end{array} & \begin{array}{c}\text { Magnesium } \\ \text { High Performance Alloys }\end{array} \\ \text { Lanthanum } & \begin{array}{c}\text { Intermetallics } \\ \text { Hydrogen Storage Alloys }\end{array} \\ \text { Neodymium } & \begin{array}{l}\text { Magnesium } \\ \text { High Performance Alloys }\end{array} \\ \text { Yttrium } & \begin{array}{c}\text { Magnesium } \\ \text { High Performance Alloys }\end{array} \\ & \text { Hydrogen Getter Discharge Lamps }\end{array}$

Unocal / Molycorp blk $10 / 87$

Figure 14. Applications for lanthanide metals requiring affinity for elements other than oxygen or sulfur. 


Cerium
Praseodymium
Neodymium
Samarium
Gadolinium

Terbium

Dysprosium

Holmium

\section{Additive, Sm-Co}

(Pr.Sm)-Co5

$\mathrm{Nd}-\mathrm{Fe}-\mathrm{B}$

Sm-Co5, Sm2-(Co,X)17

Magneto-optics

Refrigeration

Additive, Sm-Co

Magneto-striction

Magneto-optics

Additive, $\mathrm{Nd}-\mathrm{Fe}$

Magneto-striction

Magneto-optics

Flux Concentrator
Perm. Mag.
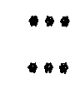

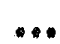

$\ldots$

$\cdots$

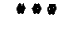

$\ldots$

Unocal / Molycorp blk 10/87

Figure 15. Applications for lanthanide metals depending upon magnetic properties.

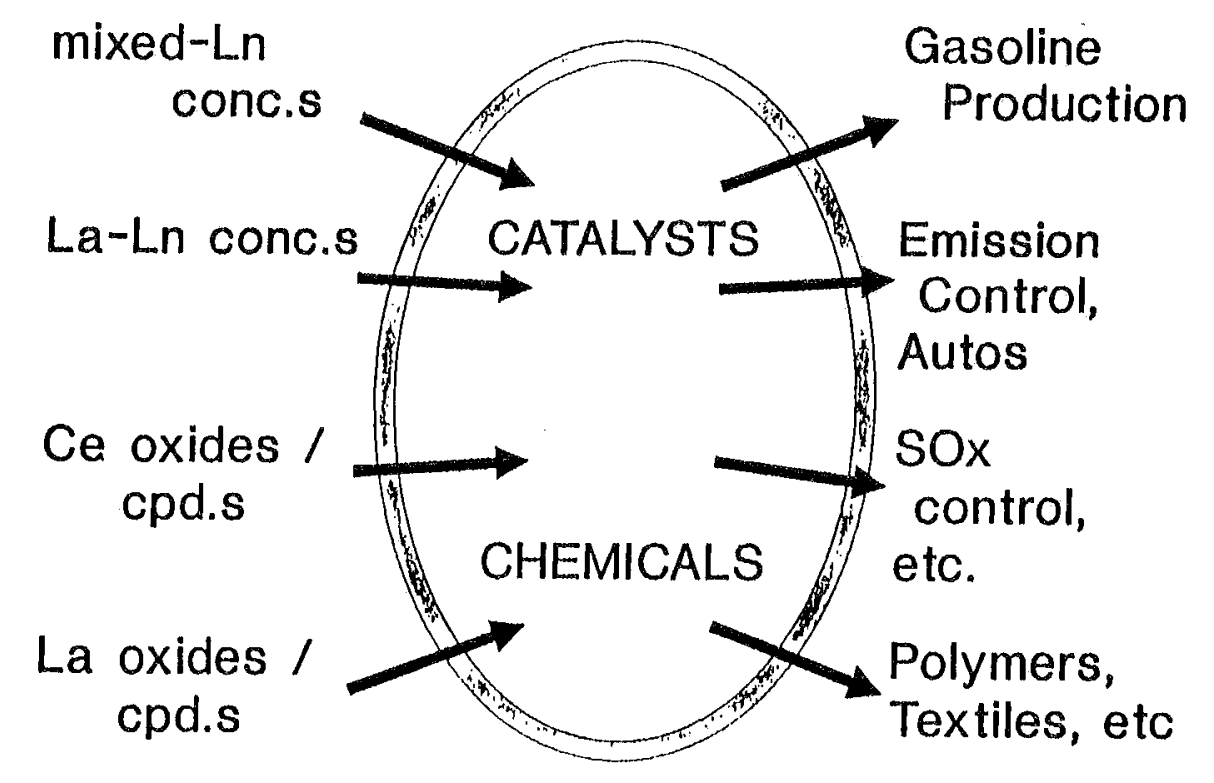

Unocal / Molycorp btk 8/88

Figure 16. Use of lanthanides in catalysts and chemicals. 


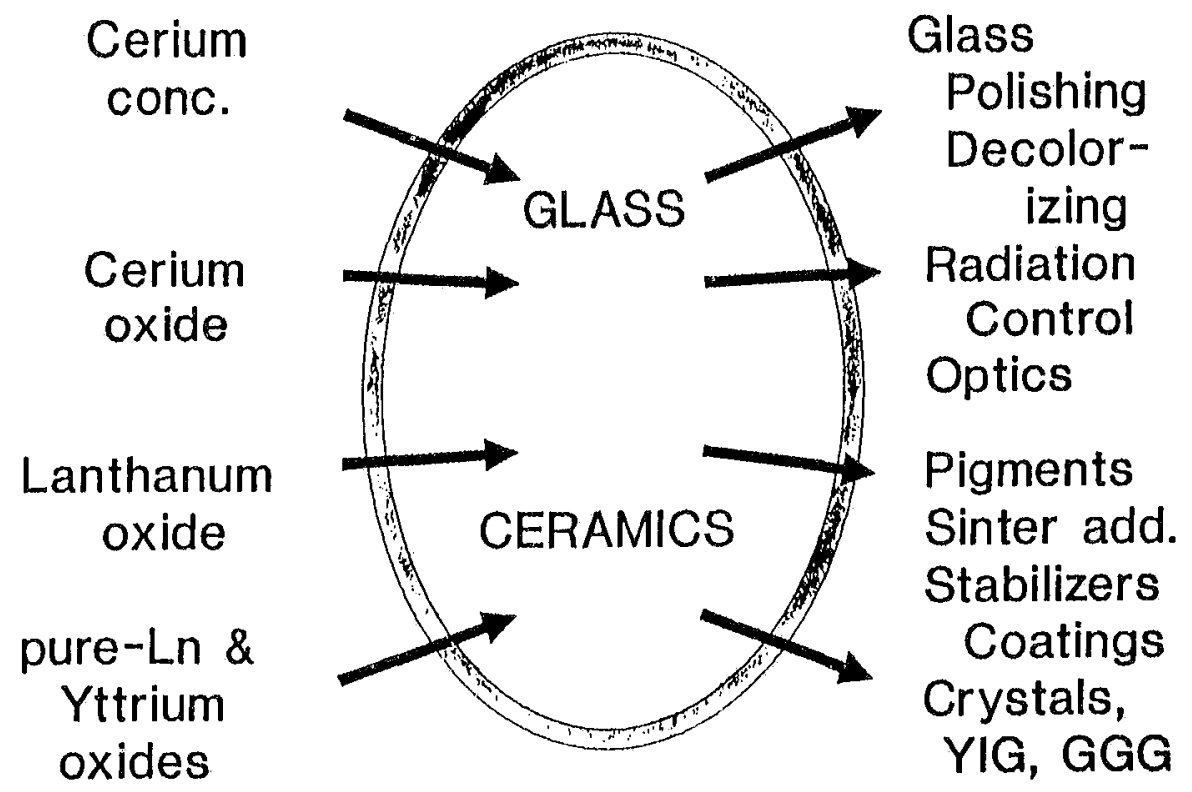

Unocal / Molycorp btk 8/88

Figure 17. Use of lanthanides in glass and ceramics.

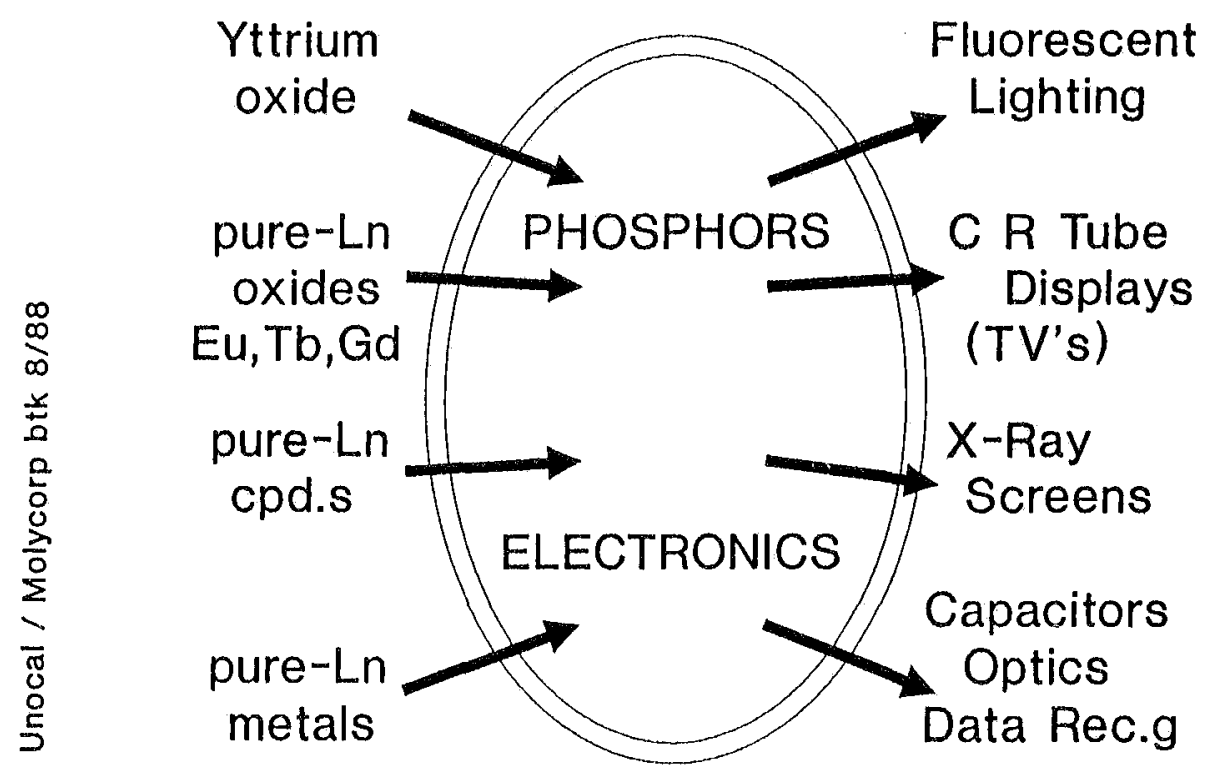

Figure 18. Use of lanthanides in phosphors and electronics. 


\begin{tabular}{|c|c|}
\hline Phosphors & $\begin{array}{l}\text { Cathode Ray Tubes } \\
\text { Fluorescent Lighting }\end{array}$ \\
\hline Ceramics & $\begin{array}{l}\text { Sintering Ald for } \\
\text { Silicon Nitride, Magnesla } \\
\text { SlAlON's, Aluminum Nitride } \\
\text { Stabllizer for Zirconla } \\
\text { Refractory Coating }\end{array}$ \\
\hline Super-Alloys & $\begin{array}{l}\text { Oxide-Dlspersion Strengthening } \\
\text { of } \mathrm{Ni}, \mathrm{Fe}, \mathrm{Cr} \text { Alloys }\end{array}$ \\
\hline $\begin{array}{l}\text { Garnet } \\
\text { Crystals }\end{array}$ & $\begin{array}{l}\text { YAG for lasers } \\
\text { YIG for microwave }\end{array}$ \\
\hline
\end{tabular}

Unocal / Molycorp blk,4 2/88

Figure 19. Specific applications of rare carths in the broad areas of phosphors, ceramics, alloys, and crys

\section{Phasphars}

INCIDENT HIGH-ENERGY RADIATION

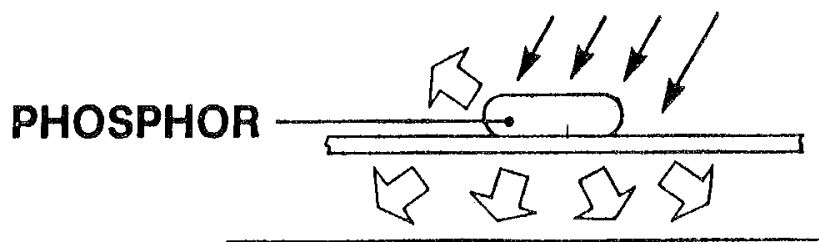

EMITTED VISIBLE LIGHT

\section{Use of Lanthanides in Phosphors for:}

TV TUBES

\section{FLUORESCENT LAMPS}

Unocal/Molycorp

\section{X-RAY SCREENS}

Figure 20. Application of lanthanides in phosphors and products using lanthanides in phosphors. 
Zeolites are aluminum silicates with big molecular-sized holes which provide a matrix of negative charges. Negatively charged aluminum silicates require addition of a positive ion to produce a stable material; this is achieved by adding lanthanides. This property is not unique to a lanthanide ion. Something else could have been used which would result in a different balance of properties of gasoline; it's always a question of the desired end product that determines which additive is used. In the past few years, new technologies have replaced lanthanides in some catalysts with zeolites which are even more stable than the traditional ones. As a result the lanthanide market for use in cracking catalysts has declined over the past few years even while it dominates worldwide production.

When there's an oil shortage, people are desperate to crack it and want a very active catalyst, a property of some rare earths. The auto catalyst monolith, part of the automobile emission control device, is a very, very fine-holed ceramic which becomes even finer as technology improves. Cerium goes into auto catalysts. Cerium and lanthanum can be added in oxide form, the slurry, and as a soluble compound. These are all possible methods of getting them into our exhaust system. If the engine is not tuned properly and the exhaust composition is fluctuating wildly, or when there is too much fuel and not enough air, cerium helps to break up the emission compound. You need reasonably pure cerium, but not the ultra-pure needed in some phosphor-electronic applications. And this use is certainly a growing market material.

Glass and ceramics applications are diagrammed in Figure 17. The concentrates are shown on the left in descending order from large-volume, low-priced materials at the top to the purer, lower-volume, higher-priced materials at the bottom. Glass polishing is an oddity. The best polishing agent for large silicate glasses is a cerium oxide slurry. Eyeglasses are almost always polished with a cerium oxide slurry but could be polished with cerium concentrate. That accounts for a large consumption of cerium concentrate. It is also used in glass decolorization. However, if you want a little more control in your system, you need a purer form (90-95-99\%) of cerium oxide.

Other glass and electronics applications are illustrated in Figure 18. The glass face plate in a TV tube contains cerium to help keep it clear. Without cerium, after hours of bombardment with high-energy electrons from the TV itself, the face plate would gradually turn muddy and brown.

A camera lens almost certainly has lanthanide oxide, a lanthanum-zirconate-barite-type glass. Cerium is used in colored glass for various signaling applications, and the concentrate is often used to decolorized glass for packaging (pop and wine bottles) and various other uses. Occasionally special filter glasses are made with neodymium, praseodymium, or even cerium. Glass containing samarium oxide provides special filtering of certain wavelengths from your camera flash lamp that energizes the laser.

Welding goggles require neodymium in the glass. Neodymium has a very, very sharp absorption line at 589 nanometers, exactly where the eye is most sensitive, and it falls at the exact location of the sodium yellow light. The brilliant yellow spectral line of the arc is absorbed by neodymium in the safety goggles.

Bathroom tile uses zirconia silicate, not a zirconate. Praseodymium is also used as a special pigment in yellow tiles. Normally praseodymium prefers the trivalent state like all other lanthanides. But in this one application, it is a tetravalent ion. Although the tetravalent ion 
is normally so reactive that it isn't available, when locked in a very stable lattice it will have some very nice properties which produce the zircon-praseodymium light, called praseodymium yellow.

Some of the structural pieces now being considered for combustion engine parts and protective coatings use lanthanides as additives. There are growing applications in film barrier coatings as well as in protecting metals operating in high-temperature environments like engines or power stations. A plasma spray coat of yttrium-stabilized zirconia gives metal a much longer life and supports a significant market for yttrium oxide. These elements are novel because they have sites which are electrically conducting. Conduction occurs either electronically through electrons, or ionically through movement of oxide ions. Conductive ceramics, even at high temperatures, will be a growing market.

As we run into problems of power station production, power station buildup, nuclear power station problems, coal-burning problems, or the need for smaller, more efficient power production, fuel cells will play a significant role. Silicon nitrite turbo-boosters are now used in one or two Japanese cars, such as Nissan vehicles. Silicon nitrite can also be used in missile turbines, crucibles, and a variety of gear chain sprockets that run at high temperatures.

The potential use of rare earths in ceramics partially depends on their property of interchangeability (Figure 19) for quite a few applications. Zirconate silicon nitrite, a superconducting material, has been mentioned, as well as various garnets. In many applications, yttrium or lanthanum, or cerium or yttrium, could be used depending on the cost factor. Larger volume applications will use cerium or even lanthanum. Cerium is cheaper, but many times it doesn't have the right properties so there has been a lot of development work particularly using yttrium. For example, the market for yttrium may appear to be growing because yttrium stabilizirconia is used to line the piston chambers of your automobile engine, but ongoing research may find that a cerium stabilizirconia works well, too. The material used in prototype development may not be used in the end product.

The most colorful application of lanthanides is in the phosphors in TV screens. Only lanthanides can be used, and quite often only one specific lanthanide can do the job in some of these applications. So growth of demand depends on market size of the application. Yttrium oxide does not emit color from the TV screen, but serves as the host, the inert structural matrix. The emitting materials are doped into the matrix at concentrations of $1 \%$, $0.5 \%, 5 \%, .01 \%$ in the actual phosphor material itself. Hence, the maximum bulk consumption comes in the yttrium oxide host, not the pure material. Pure materials are more expensive than host materials, but future market value might be modified. The red in your television is due to yttrium europium oxysylfide. X-rays use a lanthanide-based phosphor to convert high-energy radiation into visible light (Figure 20). Terbium produces a green color under electron impact.

The fourth category is phosphors and they generally require high-purity materials, thus higher value but reduced volume. Europium is used in TV tubes and in fluorescent tubes, in X-ray screens to make the X-ray photograph, and in a new type of folded fluorescent tube. Europium produces a certain energy level transition precisely at the nice red wavelength of the eye, about 610 to 650 nanometers. It is little affected by environmental variations, and there is no competitive alternative material for this kind of application in which a very sharp wavelength is required. The red emission produced by other materials is not a precise 
enough wavelength for some applications here. Phosphors function well in a vicious vacuum environment being hit by high-energy electrons. This is because the base matrix, yttrium oxide or yttrium compounds, is stable enough for this environment.

Europium-doped yttrium oxide gives a blue coloration with a very nice, broad transition in the blue region to give this blue color. There are possibly other blue phosphors, but blue is a difficult color to produce since the right host lattice is necessary to contain the element. If cerium is used as the additive sensitizer, you get a good, clean emission. In fluorescent tubes the precise intensity of emissions is crucial for obtaining the right color balance, and there are now, at last, a lot of other possible host lattices.

There are other various illuminates being developed today such as lanthanum luminate, lanthanum borates, and gadolinium borates. Each of these is an attempt to get better color efficiency with better lighting efficiency. Various lanthanide oxides or europium-doped yttrium oxide which contain sharp and very few sidebands (only about 6 to 10 nanometers) have quite a few uses in fluorescent tube manufacturing. The spectrum emitted by the new three-prime fluorescent light looks like white light because the colors are balanced and matched very, very efficiently. A color matched under this light will be the same as if matched under sunlight. If you try to match two colors, one under conventional fluorescent tubes and then one under sunlight, they will not be the same.

When an $\mathrm{x}$-ray picture is taken, the screen has to absorb the x-radiation and emit the light radiation. Phosphors in x-ray screens have to have a lanthanide-containing host lattice, a high atomic number. Gadolinium has a higher atomic number than lanthanum so there is more efficient absorption. Terbium, probably as terbium-doped gadolinium oxysulfide, can be used in a green sensitive film for $\mathrm{x}$-ray.

In addition to lanthanides used in phosphors, there are some uses in various electronic applications such as capacitors. The tendency of electronic equipment over the past decade has been miniaturization; capacitors today are small and efficient. In the case of special multilayered capacitors, addition of some lanthanide oxides gives the best properties. Other uses include ferrites, memories, and storage materials.

In microwave communications, the selectivity of individual frequencies is chosen by manipulating the magnetic field around crystalline devices such as polycrystalline yttrium ion garnets. This is an application for very high-purity yttrium oxide. These polycrystalline garnets are made in various shapes and sizes. One of the most commonly used is a very small, very accurately shaped sphere used in microwave equipment. An yttrium ion garnet is the ideal material for this use. A computer with a nonvolatile memory can actually store material as a bubble on a special film on a gadolinium-gallium-garnet (GGG) crystalline substrata. The purity of gadolinium is high. A tiny amount of lutetium, 0.42 percent in a film that is 100 angstroms thick, is used in many computers or data reporting systems.

PLZT, an electronic material to produce visual displays, is made with lead, lanthanum, zirconium, and titanium. It cannot compete directly with liquid crystal devices, but under certain conditions requiring high-speed operation or wide temperature range it is effective and the preferred material for use. 



\title{
Uranium-Thorium Deposits as Pathfinders for Rare-Earth Element Exploration in Alaska
}

\author{
Dr. Robert B. Forbes \\ Director and State Geologist \\ Alaska Division of Geological and Geophysical Surveys
}

\begin{abstract}
Introduction
As most of you know, there is a strong correlation between the occurrence of some uranium and thorium deposits and the rare earths. Because of the amenability of uranium and thorium to detection by airborne prospecting methods, and therefore as possible guides to companion or associated rare-earth deposits, I thought it would be valuable to present a summary of uranium and thorium deposits and exploration programs in Alaska. Later James Barker will address Alaska rare-earth deposit types, some of which are indeed associated with anomalous concentrations of uranium and thorium.
\end{abstract}

\section{Uranium-Thorium Exploration in Alaska}

Although uranium-thorium exploration in Alaska has continued at various levels since 1945, as influenced by national needs and uranium-thorium market prices, the exploration is highlighted by two surges of activity (Table 1). The first surge extended from the late World War II years to about 1960, when uranium reserves were being increased and exploration efforts were rewarded by new and exciting discoveries on the Colorado plateau and adjacent areas. The second surge of activity occurred from 1975 to 1980 under the aegis of the Department of Energy's National Uranium Resource Evaluation (NURE) program, generating accelerated exploration activity in Alaska by U.S. Geological Survey (USGS), U.S. Bureau of Mines (USBM), Alaska Division of Geological \& Geophysical Survey (DGGS), University of Alaska, and several contractors from private industry. This second surge was actually anticipated by DGGS when Gil Eakins of that agency initiated an Alaska uranium resource survey which continued into the late 1960's, and later to 1980 with NURE program support (Eakins 1969).

Considerable public and private sector interest was generated during both of these surges, resulting in increased prospecting and exploration activity. In fact, Alaska's most important uranium and thorium discovery was made by Alaskans Don Ross and Kelly Adams during the 1945-1960 period. Using a very primitive hand-held Geiger counter in a small airplane, they located the Bokan Mountain deposit in peralkaline granite on Prince of Wales Island in 1955. This discovery eventually became Alaska's only producing uranium and thorium mine, the Ross-Adams Mine (Figure 4).

\section{Crustal Abundance of Uranium and Thorium}

Before discussing the prospecting methodologies used in the NURE program and other exploration efforts, it is necessary to understand the relative abundance of uranium and thorium in Earth's crust, representative rock types, and lake and river water. Table 2, 
compiled from various references, lists uranium-thorium concentrations in parts per million (ppm). These data are fundamental to any geochemical sampling program, establishing adjusted regional geochemical gradients and the background thresholds essential to the definition of significant geochemical anomalies. Average uranium and thorium concentrations are, of course, higher in granitic rocks than in the more iron- and magnesiumrich extrusive and intrusive igneous rocks. Among sedimentary rocks, shales (versus limestones) tend to be somewhat enriched in uranium and thorium. But as any explorationist knows, there are many exceptions to these average values. Some rocks, including shales and phosphorites, are selectively enriched in uranium and thorium beyond the average values shown in Table 2 .

Clearly, ore-grade concentrations must greatly exceed the values shown in Table 2 if they are to be of economic interest. A pervasive discussion of uranium and thorium ore deposit types and their geologic setting would demand much more time that we have today. However, a hasty review of the major deposit types, particularly those known to occur in Alaska, seems appropriate.

\section{Classification of Uranium-Thorium Deposits}

Using the most simplified classification system, we can subdivide uranium and thorium deposits into primary types, and secondary types, and those which continue to be of controversial origin (Table 3).

Primary deposits are those which are associated with the emplacement and differentiation of igneous rocks, including dike rocks, pegmatites, and associated mineralized veins. Secondary deposits include sandstone hosted "roll-front" deposits (Figure 1), and economically important concentrations of uranium-thorium bearing minerals in placer gravels which may also contain rare-earth bearing minerals of economic interest. Fossil placer deposits such as the uranium-bearing Blind River conglomerate in Canada, also contain anomalous concentrations of rare earths.

Some deposits, including tabular and vein-like occurrences emplaced in sedimentary and metamorphic host rocks, are of controversial origin. In some cases, there seems to be no clear relationship between such deposits and magmatic or intrusive igneous sources, yet ore minerals signal higher temperatures than those associated with the genesis of typical sandstone-hosted deposits.

Uranium and thorium are preferentially concentrated in selected minerals which occur in primary, versus secondary, deposits, but some of these minerals occur in both associations. Secondary minerals (Table 4) are characterized by the incorporation of water and reactions with other ions to form, for example, uranyl vanadates and phosphates. Uranium and thorium also have an affinity for organic carbon, leading in some cases to ore-grade deposits associated with woody debris and asphaltic residue in very hard to iden ify organo-uranium complexes.

Fortunately we can use uranium and thorium as very effective pathfinders in our search for rare earths as these elements emit gamma radiation which can be detected and measured with various radiometric devices including gamma scintillation counters and fission track detectors (Table 5). In addition, we are assisted by radon, a gaseous decay product of the 


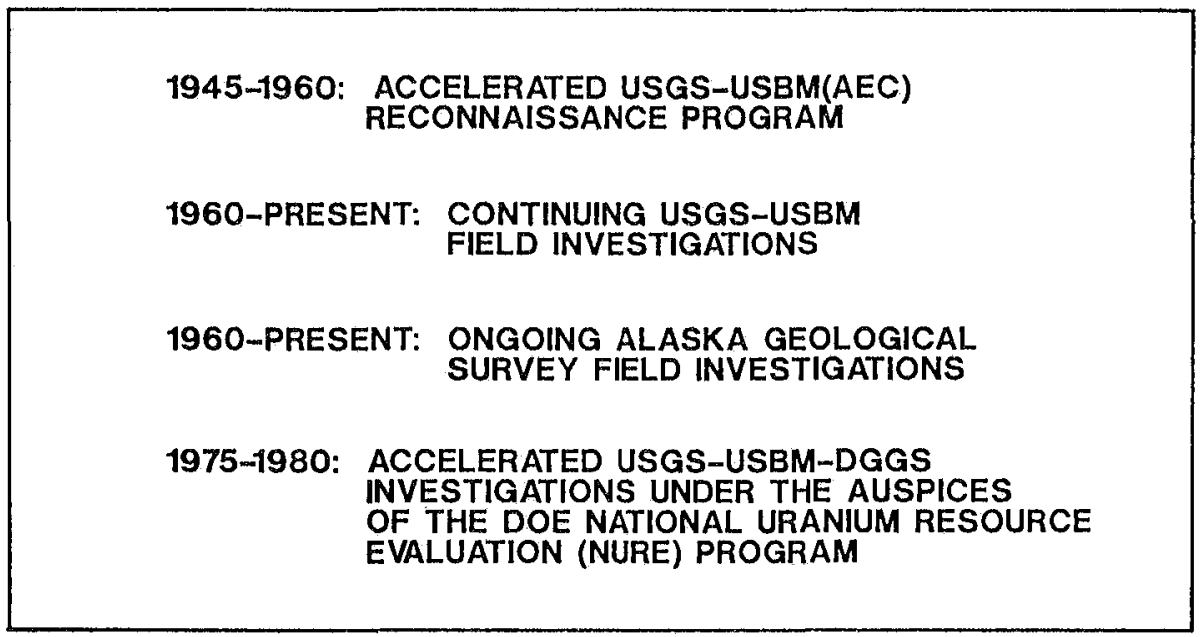

Table 1. Alaska uranium-thorium exploration and inventory programs.

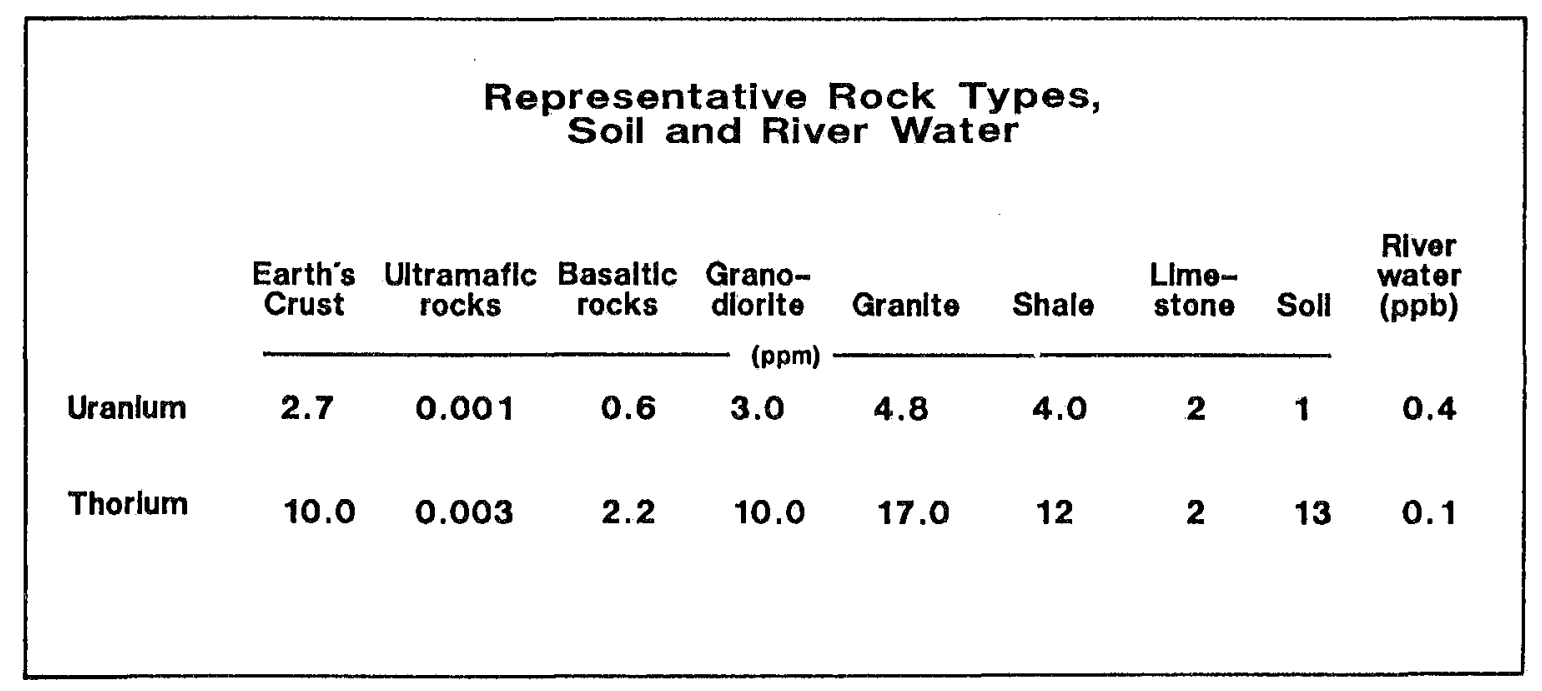

Table 2. Average worldwide abundance of uranium and thorium in Earth's crust. 


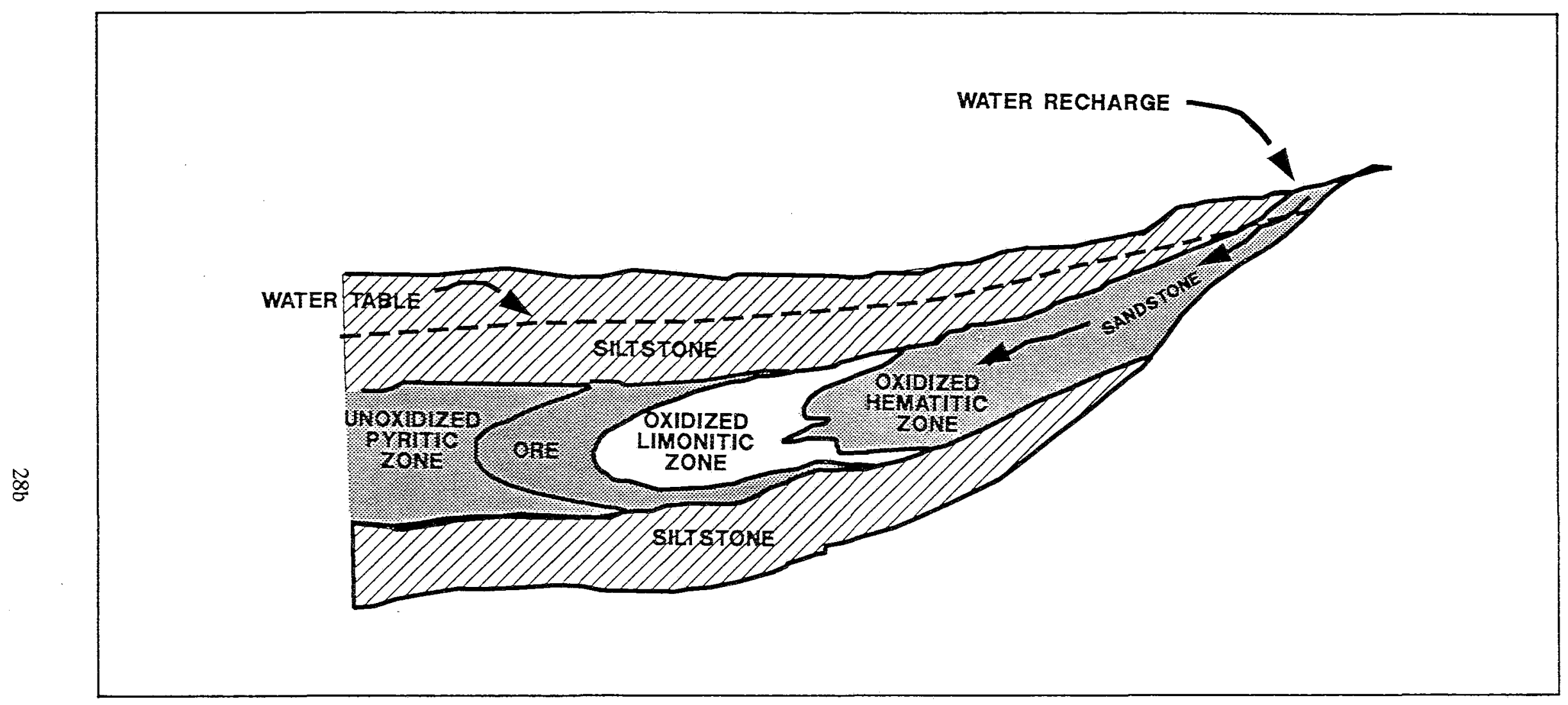

Figure 1. Diagramatic representation of roll-type uranium deposits in sandstone (Adler 1974). 


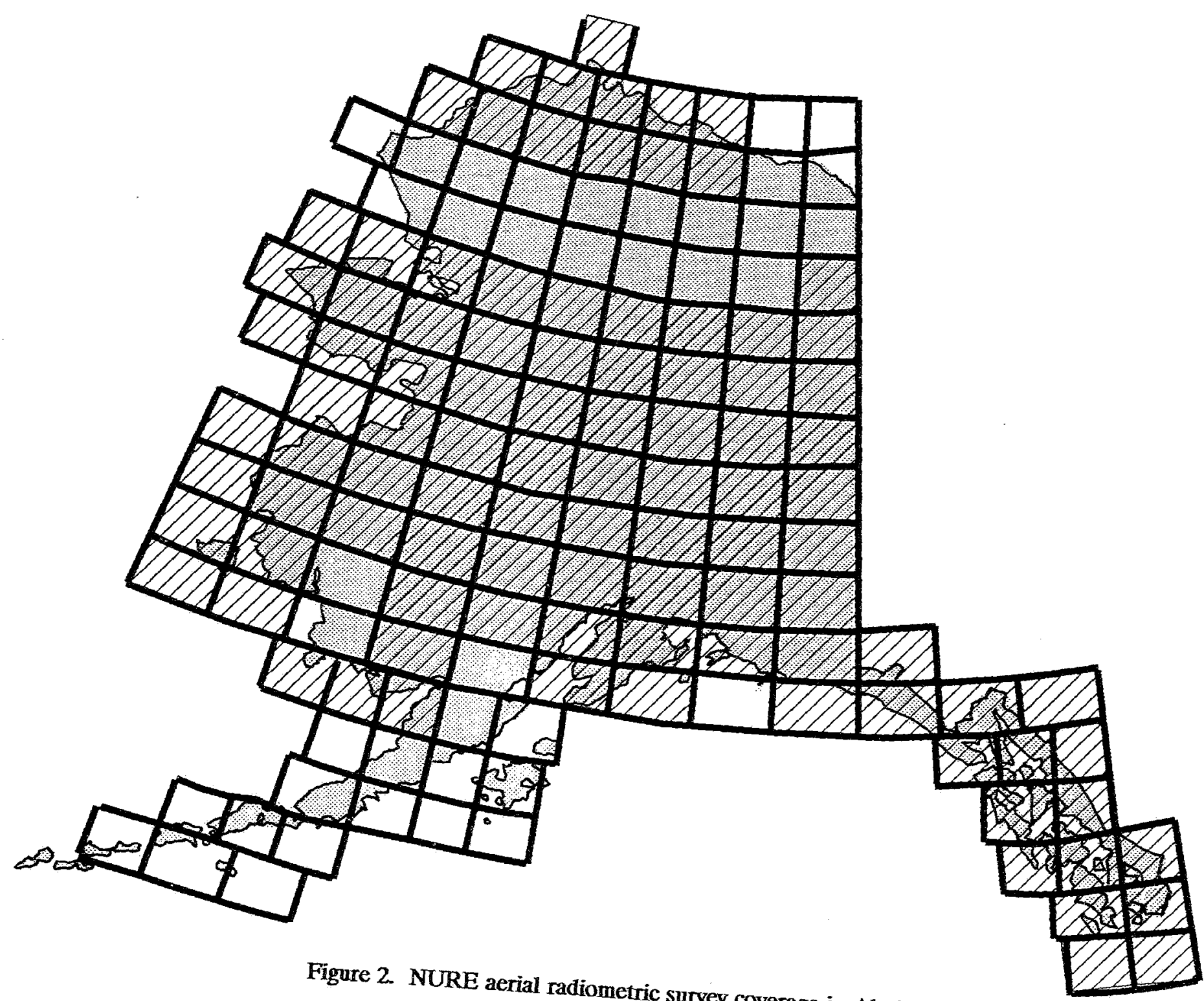

Cross-hatched areas 


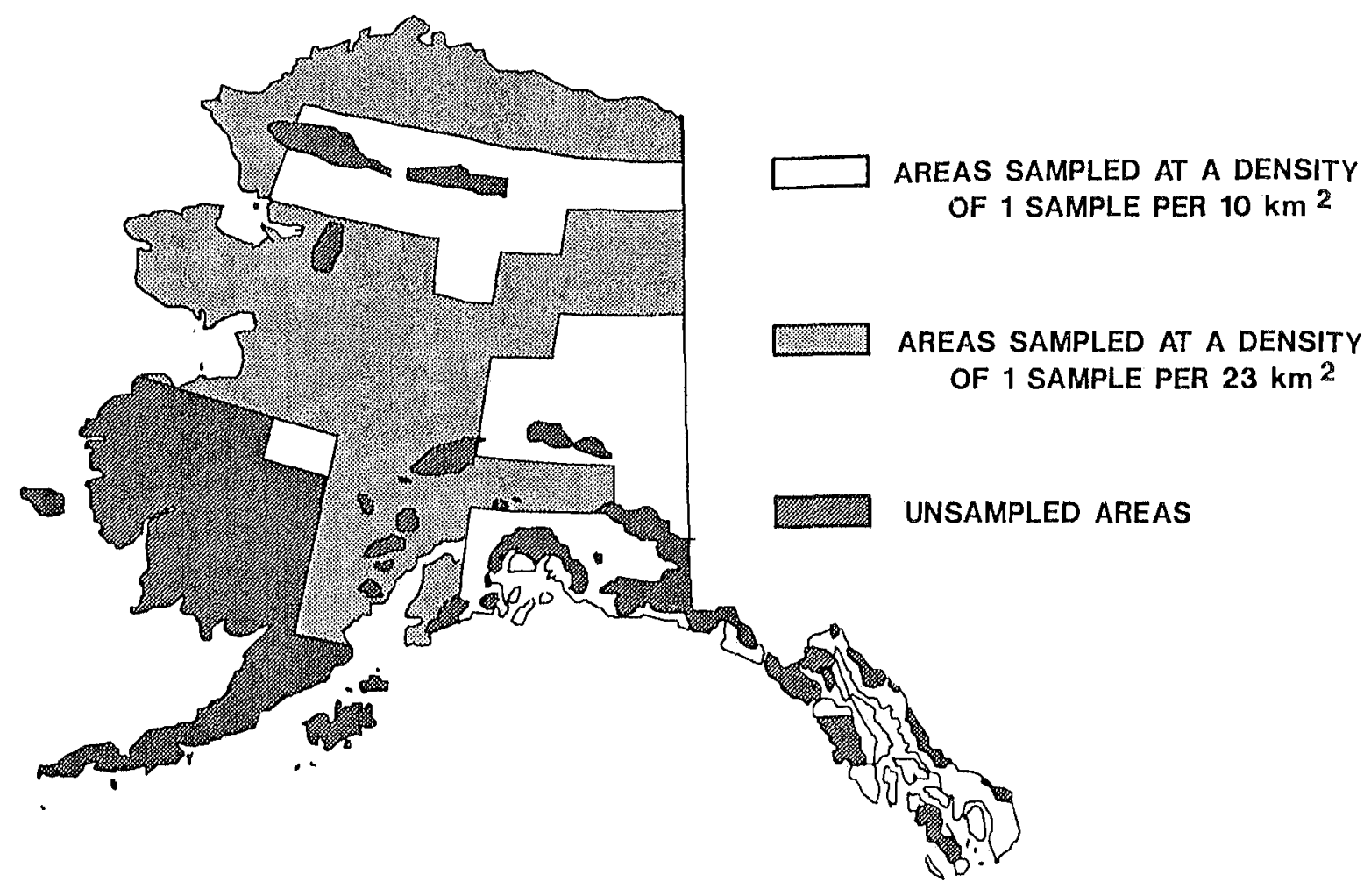

Figure 3. NURE hydrogeochemical and sediment sampling coverage in Alaska.

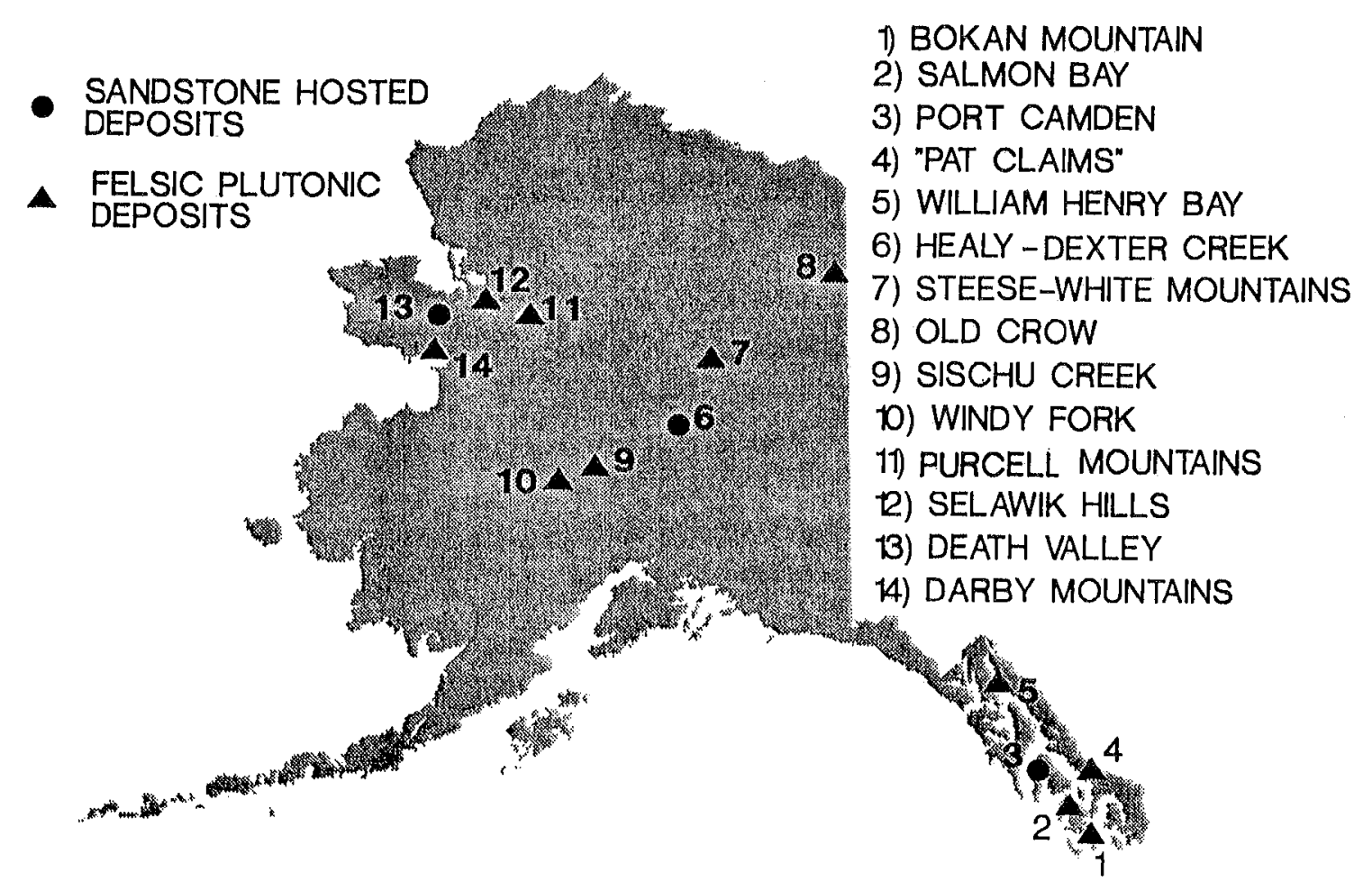

Figure 4. Alaska uranium-thorium deposits. 


\section{Primary}

Deposits related to igneous and metamorphic rocks

1. Carbonatites

2. Alkalic Igneous rocks

3. Pegmatites

4. High grade metamorphic rocks (Rössing type)

\section{Secondary}

Sediment hosted deposits

1. Roll-type deposits In Sandstones

2. Saltwash-type Uranlum-Vanadlum deposits

3. Humate Uranlum doposits

4. Fossil placer deposits

5. Modern placer deposits

\section{Controversial Origin (?)}

1. Marysvale, Utah

2. Athabasca-type

Table 3. Uranium-thorium deposit types.

PRIMARY:

URANINITE (PITCHBLENDE) $\mathrm{UO}_{2}$

THORITE (URANOTHORITE) (Th, U) $\mathrm{SiO}_{4}$

MONAZITE (Ce,La, Y,Th)PO ${ }_{4}$

EUXENITE (NIOBATE-TITANATE OF REE INCLUDING U)

$U$ AND Th ENRICHMENT IN ACCESSORY MINERALS

SECONDARY:

CARNOTITE $\mathrm{K}_{2}\left(\mathrm{UO}_{2}\right)_{2}\left(\mathrm{VO}_{4}\right) \cdot 3 \mathrm{H}_{2} \mathrm{O}$

AUTUNITE (META-AUTUNITE) Ca $\left(\mathrm{UO}_{2}\right)\left(\mathrm{PO}_{4}\right)_{2} \cdot 10-12 \mathrm{H}_{2} \mathrm{O}$

TOBERNITE (META-TORBENITE) $\mathrm{Cu}\left(\mathrm{UO}_{2}\right)_{2}\left(\mathrm{PO}_{4}\right)_{2} \cdot 8-12 \mathrm{H}_{2} \mathrm{O}$

TYUYAMUNITE $\mathrm{Ca}\left(\mathrm{UO}_{2}\right)\left(\mathrm{VO}_{2}\right) \cdot 5-8 \mathrm{H}_{2} \mathrm{O}$

THOROGUMMITE Th $\left(\mathrm{SiO}_{4}\right)_{1-x}(\mathrm{OH})_{2}$

COFFINITE U(SIO $)_{1-x}(\mathrm{OH})_{2}$

ORGANO-URANIUM COMPLEXES IN URANIFEROUS ASPHALTITE

Table 4. Principal uranium-thorium-bcaring minerals in ore deposits. 
AIRBORNE:

GAMMA SCINTILLATION COUNTERS

RADON DETECTORS

SURFACE:

GAMMA SCINTILLATION COUNTERS

RADON DETECTORS

"SNIFFERS"

TRACK ETCH CUPS

HYDROGEOCHEMICAL SURVEYS

STREAM SEDIMENT \& ROCK GEOCHEMICAL SURVEYS

Table 5. Uranium and thorium prospecting aids.

\begin{tabular}{|c|c|c|c|c|}
\hline Analytical Technique & Element(s) & $\begin{array}{l}\text { Lower } \\
\text { Detectlon } \\
\text { Llmitt (ppm) }\end{array}$ & $\begin{array}{c}\text { Crustal } \\
\text { Abundance } \\
(\mathrm{ppm})\end{array}$ & $\begin{array}{l}\text { Percent of } \\
\text { Samples } \\
\text { Detection } \\
\text { Llmlt }\end{array}$ \\
\hline $\begin{array}{l}\text { Delayed Neutron } \\
\text { Counting }\end{array}$ & Uranlum & 0.01 & 1.8 & 99.98 \\
\hline $\begin{array}{l}\text { Instrumental Neutron } \\
\text { Activation Analysis } \\
\text { Short-llved } \\
\text { radionuclldes } \\
\text { counted } 21 \text { minutes } \\
\text { after Irradlation }\end{array}$ & $\begin{array}{l}\text { Aluminum } \\
\text { Barlum } \\
\text { Calclum } \\
\text { Dysproslum } \\
\text { Magneslum } \\
\text { Manganese } \\
\text { Potasslum } \\
\text { Sodlum } \\
\text { Strontlum } \\
\text { Titanlum } \\
\text { Vanadlum }\end{array}$ & $\begin{array}{l}3200 \\
150 \\
1000 \\
0.7 \\
2700 \\
55 \\
3400 \\
1000 \\
400 \\
750 \\
6\end{array}$ & $\begin{array}{l}81300 \\
425 \\
36300 \\
3.0 \\
20900 \\
950 \\
25900 \\
28300 \\
375 \\
4400 \\
135\end{array}$ & $\begin{array}{l}99.6 \\
87.6 \\
89.8 \\
92.8 \\
90.4 \\
99.9 \\
83.0 \\
99.9 \\
5.8 \\
92.7 \\
98.1\end{array}$ \\
\hline
\end{tabular}

Table 6. Elements analyzed in sediment samples taken in NURE HSSR survey. 


\begin{tabular}{|c|c|c|c|c|}
\hline Analytical Technique & Element(s) & $\begin{array}{c}\text { Lower } \\
\text { Detection } \\
\text { Limit (ppm) }\end{array}$ & $\begin{array}{c}\text { Crustal } \\
\text { Abundance } \\
(\mathrm{ppm})\end{array}$ & $\begin{array}{c}\text { Percent of } \\
\text { Samples } \\
\text { Detection } \\
\text { Limlt }\end{array}$ \\
\hline $\begin{array}{l}\text { Instrumental Neutron } \\
\text { Activation Analysis } \\
\\
\text { Long-lived } \\
\text { radlonuclides } \\
\text { counted } 14 \text { days } \\
\text { after irradiatlon }\end{array}$ & $\begin{array}{l}\text { Antlmony } \\
\text { Cerlum } \\
\text { Ceslum } \\
\text { Chromium } \\
\text { Cobalt } \\
\text { Europlum } \\
\text { Gold } \\
\text { Hafnlum } \\
\text { Iron } \\
\text { Lanthanum } \\
\text { Lutetlum } \\
\text { Scandium } \\
\text { Tantalum } \\
\text { Terbium } \\
\text { Thorium } \\
\text { Ytterblum } \\
\text { Zinc }\end{array}$ & $\begin{array}{l}1 \\
10 \\
2 \\
10 \\
1.7 \\
0.4 \\
0.05 \\
1.3 \\
1100 \\
7 \\
0.1 \\
0.9 \\
1 \\
1 \\
1 \\
1 \\
100\end{array}$ & $\begin{array}{l}0.2 \\
60 \\
3 \\
100 \\
25 \\
1.2 \\
0.004 \\
3 \\
50000 \\
30 \\
0.5 \\
2.2 \\
2 \\
0.9 \\
7.2 \\
3.4 \\
70\end{array}$ & $\begin{array}{l}5.0 \\
93.2 \\
51.1 \\
92.9 \\
94.5 \\
90.8 \\
1.0 \\
87.2 \\
99.0 \\
79.2 \\
81.2 \\
99.5 \\
2.4 \\
4.8 \\
90.7 \\
60.9 \\
46.4\end{array}$ \\
\hline
\end{tabular}

Table 7. Elements analyzed in sediment samples taken in NURE HSSR survey (continued). 


\begin{tabular}{|c|c|c|c|c|}
\hline Analytical Technique & Element(s) & $\begin{array}{c}\text { Lower } \\
\text { Detection } \\
\text { Limit (ppm) }\end{array}$ & $\begin{array}{c}\text { Crustal } \\
\text { Abundance } \\
(\mathrm{ppm})\end{array}$ & $\begin{array}{c}\text { Percent of } \\
\text { Samples } \\
\text { Detection } \\
\text { Limit }\end{array}$ \\
\hline $\begin{array}{l}\text { Energy-Dispersive } \\
\text { X-ray Fluorescence }\end{array}$ & $\begin{array}{l}\text { Arsenic } \\
\text { Blsmuth } \\
\text { Copper } \\
\text { Lead } \\
\text { Nickel } \\
\text { Selenlum } \\
\text { Sllver } \\
\text { Tin } \\
\text { Tungsten } \\
\text { Zirconium }\end{array}$ & $\begin{array}{l}5 \\
5 \\
10 \\
5 \\
15 \\
5 \\
5 \\
10 \\
15 \\
5\end{array}$ & $\begin{array}{l}1.8 \\
0.2 \\
55 \\
13 \\
75 \\
0.05 \\
0.07 \\
2 \\
1.5 \\
165\end{array}$ & $\begin{array}{l}73.9 \\
9.9 \\
90.8 \\
55.1 \\
76.6 \\
0.3 \\
0.3 \\
1.6 \\
5.8 \\
85.2\end{array}$ \\
\hline $\begin{array}{l}\text { Arc-Source Emission } \\
\text { Spectrography }\end{array}$ & $\begin{array}{l}\text { Beryllium } \\
\text { Lithium }\end{array}$ & $\begin{array}{l}1 \\
1\end{array}$ & $\begin{array}{l}2.8 \\
20\end{array}$ & $\begin{array}{l}70.0 \\
99.3\end{array}$ \\
\hline
\end{tabular}

Table 8. Elements analzyed in sediment samples taken in NURE HSSR survey (continued). 
uranium 238 decay series which can be detected by both gamma counters and radon sniffers. Surface and airborne surveys are performed with gamma scintillation counters and radon detection instruments and are supplemented by more definitive water, sediment, and rock geochemical surveys.

\section{NURE-Sponsored Airborne Reconnaissance Programs}

The NURE program expended a tremendous amount of effort on regional airborne surveys and follow-up helicopter-based water and sediment geochemical surveys. The results of these surveys were subsequently checked by follow-up surface investigations of anomalies that were defined by the airborne reconnaissance program.

Regional airborne radiometric surveys flown in Alaska under the NURE program are recorded on the index map shown in Figure 2. Note that much of Alaska has been flown with the exception of a few areas in northern and southwestern Alaska. Geomagnetic profiling was also completed along the same flight lines. This information is of considerable value in our search for valuable ore deposits other than uranium and thorium in Alaska.

Many radiometric anomalies were defined by these airborne surveys resulting in follow-up investigations by USGS, USBM, and DGGS. Several important discoveries were made through this process, including uranium, thorium, and rare-earth deposits.

\section{NURE Surface Geochemical Sampling Program}

Figure 3, an index map, shows the regional coverage of the NURE program's Hydrogeochemical and Stream Sediment Reconnaissance (HSSR) survey, and the sample data that are now on file. The surface sampling program was designed to duplicate coverage of the airborne radiometric survey with a few minor exceptions. The main objective of this survey was to obtain the geochemical definition of uranium and thorium anomalies which might hopefully coincide with anomalous peaks in the airborne radiometric data, or those which were not identified as remote sensing anomalies. The geochemical data amassed from these surveys were refined and analyzed at several Department of Energy (DOE) laboratories, including Sandia and Los Alamos, and over the years the data were digitized for statistical analyses.

Although uranium and thorium concentrations were the focal point of the survey, NURE analyzed for 39 additional major, minor, and trace elements in many sediment and water samples. This created a very valuable geochemical data base which is also useful for definition of exploration targets including particularly the rare-earth elements. The list of analyzed elements contained in this data base is shown in Tables 6, 7, and 8.

\section{Recognized Alaska Uranium-Thorium Deposits}

Based on the available information, 14 Alaska uranium and thorium deposits have been selected for discussion today as potentially minable resources, exploration targets, and pathfinder deposits related to economically interesting concentrations of rare earths. The somewhat arbitrary 14 locations selected for discussion do not include literally hundreds of 
isolated geochemical and radiometric anomalies defined in areas which may be of regional or specific interest (Figure 4).

Locality \#1 is the famous Bokan Mountain uranium-thorium deposit on Prince of Wales Island, in southeast Alaska. This deposit consists of vein-like segregations in peralkaline granite and was discovered by airborne prospecting in 1955 . The mine has produced about 49,000 tons of high-grade ore grading about $1 \%$ thorium and $1 \%$ uranium. Bokan Mountain hosts several other prospects including significant rare-earth concentrations which would merit further attention if uranium and thorium prices were higher.

Locality \#2 hosts the Salmon Bay carbonatite veins associated with lamprophyre dikes which cut low-grade metasediments. The carbonatite veins contain anomalously high concentrations of uranium, thorium, rare earths, and niobium. This occurrence is a recognized worldwide deposit type, and the vein and dike systems near Salmon Bay and at nearby Zarembo Island have received considerable attention from explorationists.

Locality \#3 is the Port Camden sandstone-uranium deposit. This deposit is of special interest as it was discovered by Gil Eakins of DGGS quite a few years ago (Eakins 1975). At the time it was the first sandstone-hosted deposit discovered in Alaska. In this case, uranium mineralization is concentrated in carbonized plant fragments in a carbonaceous sandstone of the Tertiary Kootznahoo formation. Grades of up to $0.27 \% \mathrm{U}_{3} \mathrm{O}_{8}$ subsequently have been reported by explorationists with the highest values reported from zones dominated by carbonized plant remains.

Locality \#4 is located near the Canada-Alaska boundary in southeast Alaska as listed in a recent U.S. Bureau of Mines compilation. I have no detailed comments to make on this prospect other than its inclusion in the U.S. Bureau of Mines compilation of Alaska uranium prospects.

Locality \#5 is the William Henry Bay deposit characterized by anomalous concentrations of uranium, thorium, rare earths, and niobium in veins containing pyrite, chalcopyrite, galena, thorianite, and euxenite associated with a small monzonite-syenite complex which intrudes Silurian metavolcanic and sedimentary rocks of the Alexander Belt. Some of the veins have carbonatitic affinities.

Locality \#6 is the Healy-Dexter Creek deposits defined by a Urangesellschaft drilling program in the late 1970s. Deposit types include the following: 1) roll-front deposits in the Suntrana and Healy Creek formation north of Jumbo Dome; 2) fracture coatings and fillings in micaceous schist (Birch Creek schist) in underlying bedrock and; 3) tabular deposits in conglomeratic sandstones in the basal Healy Creek formation (Dickson 1982).

The initial discovery of uranium roll-front systems in Alaska Tertiary sediments by Urangesellschaft was an extremely important landmark in Alaska uranium exploration. There was some doubt previously as to whether Alaska paleoclimatic regimes, including the development of resurgent regional permafrost, could include a groundwater migration window which would permit the development of Colorado Plateau-type roll-front uranium deposits. The concurrent discovery of sandstone and lignite-hosted uranium deposits in Healy area and Death Valley on the Seward Peninsula served notice that such conditions have existed in post-Tertiary time. Drill-hole data from roll-front zones indicate maximum grades of $0.016 \% \mathrm{U}_{3} \mathrm{O}_{8}$ over three feet of section. 
The second type of uranium mineralization was discovered in underlying Birch Creek schist and signalled by stream sediment and water geochemical anomalies. An outcrop was located which yielded $79 \mathrm{ppm} \mathrm{U}_{3} \mathrm{O}_{8}$, about 10 times local background values. The uranium mineralogy and genesis of this occurrence are not yet understood.

The third and perhaps most significant type of uranium mineralization is a tabular deposit that crops out along Dexter Creek in the headwaters of Totatlanika River. Significantly, this occurrence was discovered with the aid of airborne radiometry and follow-up stream geochemistry. The deposit is localized in sandstones interbedded with coarse-grained conglomeratic sandstones. The mineralized zone includes uraninite-bearing siderite nodules (Dickinson 1978). Dickson (1982) reported that the mineralogy probably includes uranoorganic compounds as well as uraninite. Subsurface drill-hole data indicate a two-foot thick mineralized zone with an average value of $0.068 \% \mathrm{U}_{3} \mathrm{O}_{8}$.

Locality \#7 is the Steese-White Mountain area which includes Roy Creek, Lime Peak, and Cache Mountain prospects. These deposits are associated with alkalic and tin-type granites and fissure veins containing fluorite, sulfides, and uranium-thorium enriched minerals. Although no quotable drill-hole data are available, this area should be classified as a very promising uranium-thorium and rare-earth elements province.

Locality \#8, the Old Crow pluton, is located on the Alaska- Canada boundary west of the Athabascan village of Old Crow. This pluton has alkalic affinities and hosts vein systems which contain high concentrations of rare-earth elements and uranium-thorium. Jim Barker, our next speaker, has done considerable work on these deposits, and I will defer to him to give us more information on this most interesting occurrence.

Locality \#9, the Sischu Creek occurrence, is of special interest as it is composed of strongly radioactive uranium- and thorium-rich porphyritic sanidine rhyolite and quartz porphyry flows which crop out as two belts, each of which are about 1.5 to $3 \mathrm{~km}$ wide and $6 \mathrm{~km}$ long. The two belts are associated with volcanic-plutonic complexes, silicic dikes and sills, domes, and flows. Grab samples have been obtained which assay from $0.002-0.007 \%$ uranium and $0.011-0.13 \%$ thorium.

Locality \#10, the Windy Fork pluton, is a peralkaline granite petrologically very similar to Bokan Mountain pluton on Prince of Wales Island. Windy Fork pluton contains abnormally high uranium and thorium concentrations. Grab sample values have ranged as high as $180 \mathrm{ppm}$ uranium and $400 \mathrm{ppm}$ thorium. Windy Fork pluton is one of several alkalic plutons in McGrath quadrangle, and it is clear that this area should receive further attention in respect to felsic-plutonic type uranium-thorium deposits.

Locality \#11, the Purcell Mountains is a range of hills that actually includes three plutonic complexes that have received considerable attention dating back to the 1960s and 1970s, and include Wheeler Creek, Clear Creek, and Zane Hills complexes. The Wheeler Creek occurrences include alaskites with uranothorianite and gummite in small, smokey quartz-rich veinlets. Grab samples have produced values up to $0.0125 \%$ uranium. The Clear Creek complex is characterized by syenite with bostonite dikes. Grab samples have assayed up to $0.04 \%$ uranium and $0.55 \%$ thorium. The Zane Hills complex includes rock types ranging from monzonite to granodiorite. Veinlets containing uranothorianite, betafite, uraninite, thorite, and allanite have produced high uranium values and thorium concentrations up to $0.027 \%$. 
Locality \#12, the Selawik Hills area, includes Selawik Hills and Selawik Lake complexes as first recognized and defined by Tom Miller of USGS (Miller 1972). These complexes include highly potassic and undersaturated alkalic rocks, such as pulaskites, malignites, foyaites, nepheline syenites, and alaskites.

High uranium-thorium concentrations have been recorded for samples taken from these complexes dating back to Miller's pioneering work and our DGGS reconnaissance in 1977 (Eakins, Forbes, and Jones 1977). At least one private venture, perhaps more, have drilled targets in the Selawik, but we have no information on results of these efforts.

Our sampling program produced assays as high as $139 \mathrm{ppm}$ uranium and $618 \mathrm{ppm}$ thorium from felsic dike rocks in the Selawik complex. Based on the carbonatitic affinities of some of the dike rocks, the Selawik area should be an area of continuing interest for uranium, thorium, and rare-earth elements.

Locality \#13 is Death Valley on the Seward Peninsula. I'm not sure who named this very small sedimentary basin on Seward Peninsula filled with Tertiary coal-bearing sediments, but I assure you it doesn't look anything like its California counterpart. Follow-up exploration by Urangesellschaft in the late 1970s led to discovery and exploration of sandstone-hosted uranium deposits in Death Valley. Dickinson et al. (1987) described Death Valley deposit as mainly meta-autunite in Paleocene continental sandstone. Deposits appear to be localized at the interface between coal-bearing lacustrine beds and coarse arkosic sandstone. We interpret the deposit as forming from uranium-bearing oxidized groundwater moving downslope from uraniferous granitic plutons in the Darby Mountains which reached coal beds where the uranium was precipitated. An estimated 37,500 tons of material contains $0.27 \% \mathrm{U}_{3} \mathrm{O}_{8}$ for a total resource of just under 1 million tons of $\mathrm{U}_{3} \mathrm{O}_{8}$.

DGGS takes some pride in this discovery as we first suggested in the 1970s (Eakins et al. 1977) that sedimentary basins adjacent to uranium-thorium rich felsic complexes in Alaska should be prospected for possible secondary uranium deposits, and we assigned first priority to Seward Peninsula targets.

Locality \#14 is the Darby Mountains area. Darby Mountains form a prominent northtrending range of hills extending from Cape Darby to Bendeleben Mountains to the north. The relatively high uranium and thorium values of Darby pluton have been recognized for many years dating back to the early work of Gault et al. (1953) and subsequent findings of Miller and Bunker (1976).

Darby Mountain province includes the elongate Darby pluton, the adjacent Kachauik pluton, and a few smaller intrusives including Dry Creek stock. From the outset it was clear that Darby Mountains pluton carried a uranium-thorium signature far above granitic background and a thorium content about five times the average for worldwide quartz monzonites.

In 1976 Miller reported alkaline dikes in syenites about 15 miles northeast of Golovin, Alaska, which contained as much as $0.15 \% \mathrm{U}_{3} \mathrm{O}_{8}$ and $1.05 \% \mathrm{ThO}_{2}$, and over $2 \%$ rare-earth elements. Clearly, Darby Mountains province is one of the most promising target areas for uranium-thorium and rare-earth elements exploration in Alaska. 


\section{Summary Comments}

It is important to note that several uranium-thorium deposits, including the Death Valley and Healy sandstone-hosted deposits, were discovered with the aid of NURE data, and that the full potential of existing NURE geochemical and radiometric data and follow-up contractor's reports have never been realized due to the rather abrupt decline of uraniumthorium exploration activity in the early 1980's. Most NURE geochemical data are available in digitized form on tape, and DGGS has these tapes in its files.

As a final comment, I think it is appropriate to accent the important economic intertie between uranium-thorium deposits in Alaska and possible discovery and production of byproduct rare-earth elements, if uranium-thorium prices merit attention from explorationists in the future.

\section{References}

Adler, H.H. 1974. Concepts of uranium-ore formation in reducing environments in sandstones and other sediments. Proceedings of the Symposium on the Formation of Uranium Ore Deposits, Athens, International Atomic Energy Agency, Vienna.

Dickinson, K.A. 1978. Uraninite in sideritic nodules from tertiary continental sedimentary rocks in the Healy Creek basin area, central Alaska. Pages B98-B99 in U.S. Geological Survey Circular 804-B.

Dickinson, K.A., K.D. Cunningham, and T.A. Ager. 1987. Geology and origin of the Death Valley uranium deposit, Seward Peninsula, Alaska. Economic Geology. 82(6):15581574.

Dickson, R.K. 1982. Uranium mineralization in the Nenana coal field, Alaska. Pages 37 42 in Alaska Div. of Geological and Geophysical Surveys Report 73.

Eakins, G.R. 1969. Uranium in Alaska. Alaska Div. of Geological and Geophysical Surveys Report 38, 49 pp.

. 1975. Uranium investigations in southeastern Alaska. Alaska Div. of Geological and Geophysical Surveys Report 44. 59 pp.

Eakins, G.R., R.B. Forbes, and B.K. Jones. 1977. Investigations of Alaska's uranium potential. U.S. Dept. of Energy Contract Report \#AT(05-1)-1639.

Gault, H.R., P.L. Killeen, and W.S. West. 1953. Reconnaissance for radio-active deposits in the northeastern part of the Seward Peninsula, Alaska, 1945-47 and 1951. U.S. Geological Survey Circular 250. 31 pp.

Miller, T.P. 1972. Potassium-rich alkaline intrusive rocks of western Alaska. Geological Society of America Bulletin. 83:2111-2128.

- 1976. Hardrock uranium potential in Alaska. U.S. Geological Survey Open-File Report. 14 pp. 
Miller, T.P., and C.M. Bunker. 1976. A reconnaissance study of the uranium and thorium contents of plutonic rocks of the southeastern Seward Peninsula, Alaska. U.S. Geological Survey Journal of Research. 4(3):367-377. 


\title{
Rare-Earth Elements and Yttrium in Alaska
}

\author{
James C. Barker \\ U.S. Department of the Interior \\ Bureau of Mines, Fairbanks, Alaska
}

\begin{abstract}
Rare-earth deposits in Alaska can be classified into several groups according to their geologic environment and mineralogical composition.

Weathering of silica-rich, late-stage hydrous phases of granitic intrusions produced monazitexenotime-allanite placers usually associated with tin and tungsten minerals. Additionally, rare-earth elements (REE) in silica-rich intrusions concentrate in greisens, rhyolite porphyry, and radioactive veins.

Lithophile element concentrations in some peralkaline complexes and silica-poor intrusions are derived from deeper crustal melts and generally contain higher levels of yttrium subgroup REE. Significant REE resources in polymineralic pegmatite dikes, zoned pegmatites, and epigenetic deposits are associated with peralkaline/alkaline complexes and characterized by multiple REE-niobium-uranium-thorium mineral phases. About half the total REE and yttrium in Alaska deposits occur in the heavy yttrium subgroup. In contrast to crustal-related deposits, mantle-derived intrusions (particularly carbonatite and diatreme/breccia pipes) contain the light cerium subgroup (phosphate and carbonate REE minerals) and show a pronounced lack of the yttrium subgroup.
\end{abstract}

The geology and mineral resource potential in much of Alaska is poorly known, particularly as it relates to the occurrence of lithophile elements. However, several definable trends of granites and subalkaline-to-alkaline and peralkaline rocks provide regional exploration opportunities.

\section{Introduction}

Presently known deposits and developed production capacity of rare-earth elements (REE) worldwide are more than adequate to meet current world demand. Large reserves of bastnaesite ore are available in California and Baiyun Obo, China. Beach placers containing monazite are mined in Australia, India, Brazil, and several other countries. World consumption of REE is minuscule compared with consumption of most other metals; however, unlike many traditional metals (e.g., copper and iron) that are giving way to advanced materials substitution, REE are in the forefront of new technology (Kilbourn 1988). New uses and gradually increasing consumption levels are likely in the future.

Historically, industry has utilized a commonly occurring mixture of REE oxides known as mischmetal. In contrast, many new applications are dependent on one or another of the individual rare-earth oxides (REO). Most of the world's known reserves are composed of the light or cerium subgroup of rare earths. For instance, the United States' principal source of REE located at Mountain Pass, California, contains less than $0.5 \%$ of the heavy yttrium subgroup as a percentage of total REE content (Hedrick 1985). Many new metallurgical, 
magnetic, superconductivity, and ceramic developments at least partially require the yttrium subgroup ${ }^{1}$. There are no known major REE deposits worldwide with the yttrium subgroup as the principle commodity. Presently, the major sources of the yttrium subgroup are the by-product xenotime from Malaysian placer tin mines and, to a lesser degree, the by-product monazite (which contains small amounts of yttrium subgroup) from ilmenite beach sand mining in Australia and elsewhere. Therefore, yttrium subgroup availability is dependent upon the economic viability of tin and titanium mining (Hedrick 1985).

There is an increasing need to characterize REE deposits, not just by total REE content as is customarily done, but also by mineralogy, by quantification of individual elements (including potential by-products beryllium, niobium, tantalum, zirconium, etc.), and by potential recoverability with commercially available metallurgical procedures. There is a dearth of information describing REE deposits. During the past six years, the U.S. Bureau of Mines (USBM), as part of an Alaska strategic minerals program, has attempted to develop this type of information for minerals essential to the U.S. economy. Rare earths have never been the focal point of an exploration effort since they have been generally regarded by industry as too low in unit value to pay for Alaska's higher operating costs. Several intense episodes of uranium prospecting during the 1950s and 1970s, however, resulted in brief passing note of REE occurrences associated in radioactive deposits. The following report is part of a continuing effort to summarize all available REE information and present field data.

\section{Regionäl Metallogenic Provinces}

There are at least four metallogenic provinces in Alaska with associated REE occurrences and deposits (Table 1). From north to south these include 1) Caledonian-age granites of the Precambrian to lower Paleozoic Porcupine Plateau, 2) alkaline and granitic Hogatza plutonic belt, 3) Cretaceous-age granites and alkaline rocks intruding the Yukon-Tanana crystalline terrane, and 4) the alkaline and peralkaline trend of intrusions on Prince of Wales Island in southeast Alaska. There is a possible fifth and potentially highly favorable area in southwest Alaska where differentiated granitic complexes, including alkaline and peralkaline phases, are associated with REE placer occurrences. This area is too poorly defined to be shown on Figure 2. Other isolated occurrences, such as those on Chichagof and Admiralty Islands, may also represent additional favorable regions.

\section{Deposit Classification}

Whether in Alaska or elsewhere, REE deposits can be classified into several generalized categories on the basis of geologic origin and depositional environment. Table 1 includes those categories for which there are Alaska examples. Not surprisingly, each category exhibits an independent set of mineralogical and major and trace element characteristics. Several deposit types, particularly the pegmatite dikes and granite-associated placers, have significant resource development potential, whereas others are merely geologic curiosities. Some, such as the carbonatites and associated carbonate veins, are enriched largely in the light cerium subgroup REE. Others (e.g., monazite-bearing placers in granitic terrane)

\footnotetext{
'The element yttrium, atomic number 39 , is not a rare-earth element but is traditionally included with the yttrium subgroup because of its chemical and metallurgical similarities.
} 


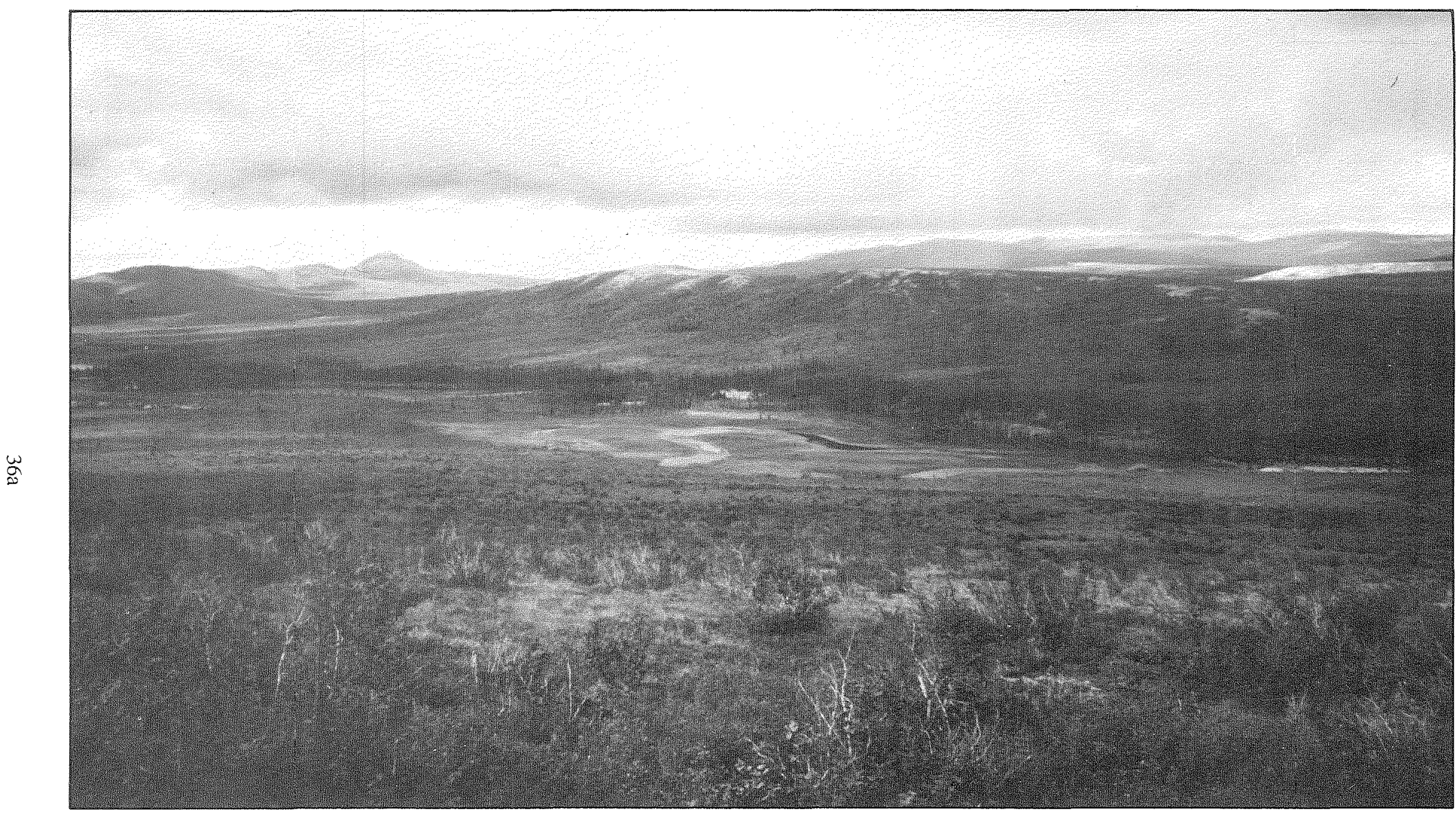

Figure 1. Photo mosaic of the Rapid River Valley in the eroded, well-rounded, and unglaciated Old Crow hills. 


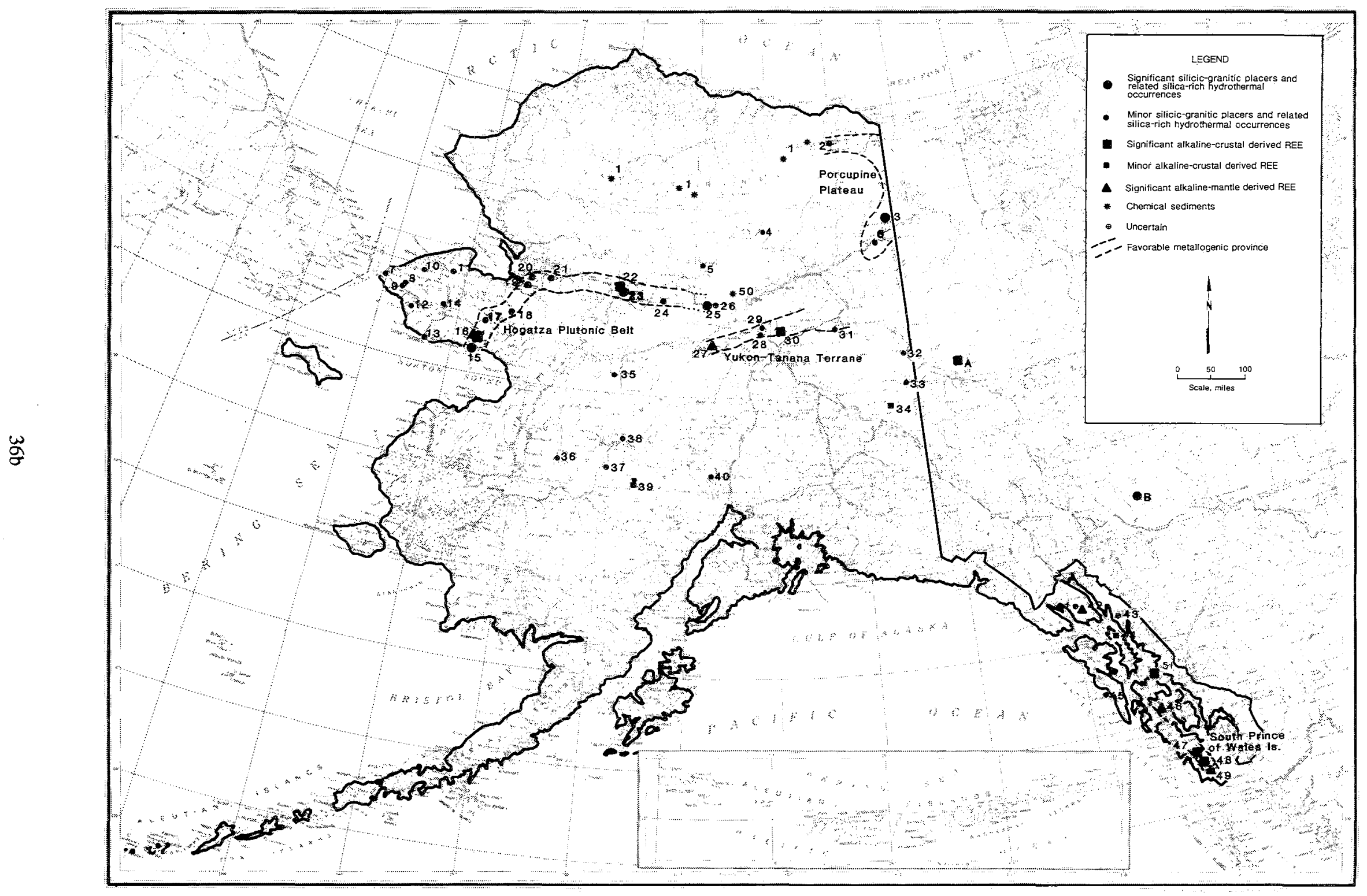

Figure 2. Rare-earth deposits in Alaska. 
Table 1. Listing of rare-earth element occurrences in Alaska.

Numbers refer to numbered locations on Figure 2.

No. Location

No. Incation

1. Northern Alaska phosphate

2. Mount Michelson

3. Old Crow Hills

4. Chandalar area

5. Rhy Creek - Gold Bench

6. Halfway Pillar

7. Cape Wales - Cape Mountain

8. Brooks Mountain

9. Lost River

10. Ear Mountain

11. Serpentine Hot Springs

12. Gold Run

13. Cape Nome

14. Kougarok

15. Golovin Bay

16. Kachauik Pluton

17. Darby Mountain

18. Granite Mountain

19. Selawik Hills - VABM Saturday

Selawik Lake Pluton

Inland Lake Pluton

Zane Hills - Boston Ridge

Hogatza River

Indian Mountain

Kanuti - Kilolitna River

\begin{tabular}{ll}
\hline 26. & Tokusatatquaten Lake \\
27. & Tofty \\
28. & Tolovana Hot Springs Done \\
29. & Livengood - Olive Creek \\
30. & Mount Prindle - Roy Creek \\
31. & Circle Hot Springs Pluton \\
32. & Eagle area placers \\
33. & Fortymile Mining District \\
34. & Mount Fairplay \\
35. & Ruby Mining District \\
36. & Idilarod \\
37. & Vinasale Mountain \\
38. & Nixon Fork \\
39. & Windy Fork - Middle Fork Plutons \\
40. & Yentna Mining District \\
41. & Berg Mountain \\
42. & William Henty Bay \\
43. & Taku Inlet \\
44. & King Salmon \\
45. & Goddard Hot Springs \\
46. & Salmon Bay \\
47. & Dora Bay \\
48. & Bokan Mountain \\
49. & Stone Rock Bay \\
50. & Ft. Hamlin Hills area \\
51. & Kook Lake \\
\hline
\end{tabular}

Table 2. Alaska deposit-types of rare-earth elements.

\begin{tabular}{|c|c|c|}
\hline \multirow[t]{2}{*}{ Element } & \multicolumn{2}{|c|}{ Silica-rich } \\
\hline & Important & Minor \\
\hline \multirow{5}{*}{$\begin{array}{l}\text { Crustal- } \\
\text { derived } \\
\text { lithophile } \\
\text { elements }\end{array}$} & \multirow[t]{5}{*}{$\begin{array}{l}\text { Granites } \\
\text { 1. Placers }\end{array}$} & Greisens \\
\hline & & Sub-volcanic \\
\hline & & Pegmatic \\
\hline & & Metamorphic \\
\hline & & Veins \\
\hline
\end{tabular}

Mantle-
derived
lithophile

Chemical

Phosphate

\begin{tabular}{ll}
\multicolumn{2}{c}{ Silica-poor } \\
Important & Minor \\
\hline $\begin{array}{l}\text { Pegmatite } \\
\text { dikes }\end{array}$ & $\begin{array}{l}\text { Alkaline } \\
\text { intrusion }\end{array}$ \\
$\begin{array}{ll}\text { Concentric } \\
\text { zoned } \\
\text { pegmatite }\end{array}$ & $\begin{array}{l}\text { 1. Disseminated } \\
\text { 2. l'acers }\end{array}$ \\
$\begin{array}{ll}\text { Epigenetic- } \\
\text { replacement }\end{array}$ & $\begin{array}{l}\text { Apatite- } \\
\text { Metasomatic }\end{array}$ \\
\hline $\begin{array}{ll}\text { Carbonatite } & \text { Diatreme } \\
\text { 1. Lodes } & \text { Carbonate } \\
\text { 2. Placers } & \text { veins } \\
\text { Minor } & \text { Kimberlite }\end{array}$ \\
\hline
\end{tabular}

Coal/coaly sediments

sediments

Phosphatic shales 


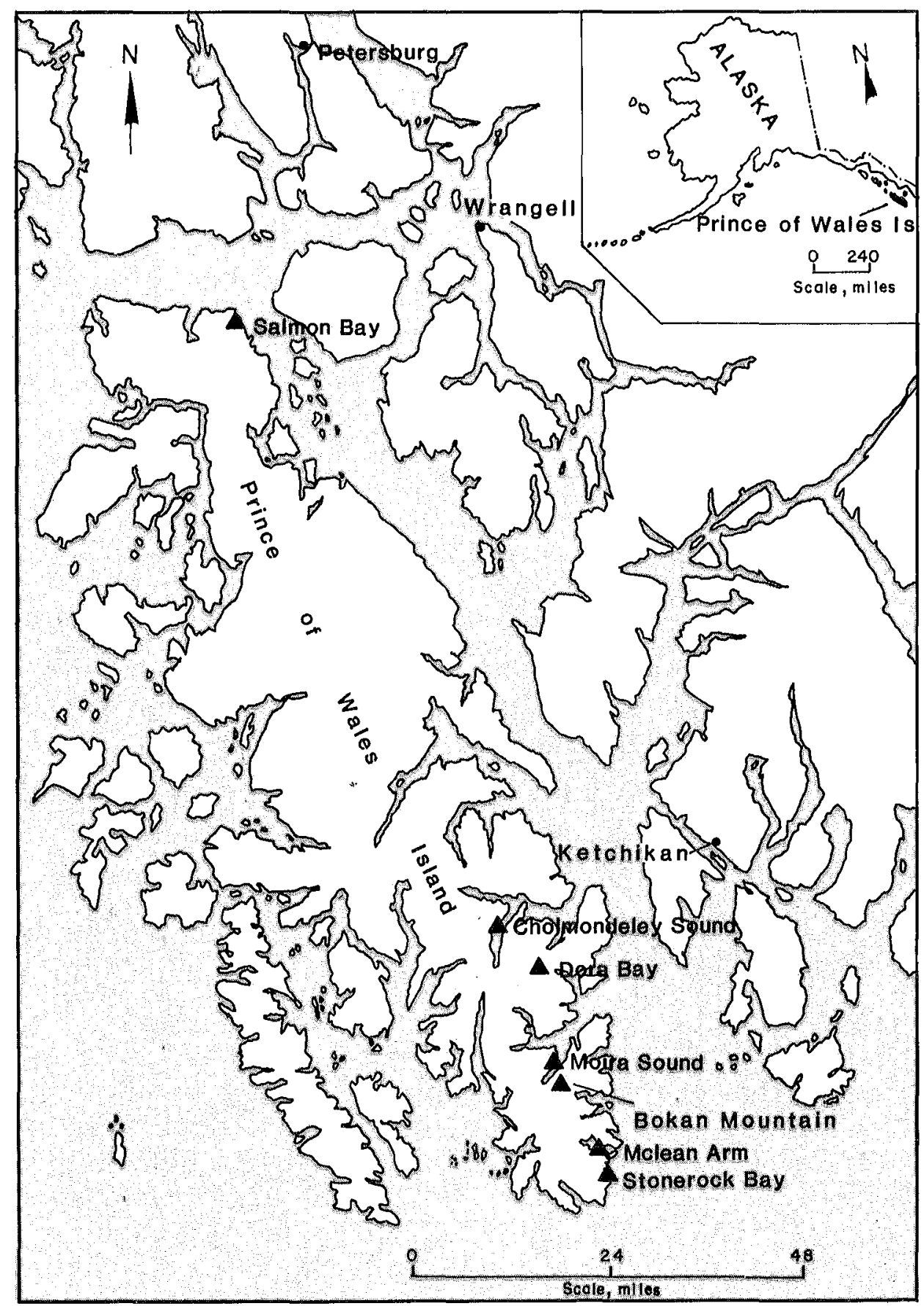

Figure 3. Rare-earth element deposits on southern Prince of Wales Island. 
contain both light and heavy REE subgroups. In Alaska, deposits associated with sodic alkaline and peralkaline intrusions are found to be more highly enriched in the heavy REE yttrium subgroup.

Silica content can be readily used to divide nearly all REE deposits between 1) those associated with granite and quartz monzonite host environments characteristically containing $70 \%$ or more $\mathrm{SiO}_{2}$, or 2) those associated with alkaline intrusive complexes that are silicadeficient or include silica-deficient phases.

\section{Silica-Rich Deposits}

Important REE deposits associated with weathering of late-stage hydrous phases of silicarich granitic complexes occur as placers containing phosphates of monazite and, less commonly, xenotime as the principal ore minerals. Allanite, a silicate, is locally abundant in some placers. The best Alaska examples are the monazite placers in the Old Crow Hills of the Porcupine Plateau (Barker 1981a, 1982) (Table 1). Placers occur within the valleys of two river systems draining the Old Crow batholith. Heavy mineral concentrates generally contain 5\% to $15 \%$ REE in addition to tin, tungsten, and niobium values. These placers have formed from a deeply eroded, anatectic, Caledonian-age batholith about 25 by 60 miles in size (Figure 1). Rare-earth minerals, as well as cassiterite, wolframite, and thorianite, for the most part originally occurred as accessory minerals disseminated throughout upper-level intrusive phases of the granite. The batholith was unroofed by at least mid- to late-Tertiary time and, as much of the Alaska interior, it has not been affected by continental glaciation. The lack of glaciation at these far northerly latitudes is due to the prevailing arid continental climate that subsequently has allowed the preservation of long-term cycles of erosion and sedimentation. This is an important geomorphic factor for placer formation, not only for the Old Crow batholith, but also for other granitic intrusive regions throughout much of interior and western Alaska.

Another series of granitic complexes examined during this project are located in the Kanuti region of the interior and are possibly an easterly extension of the Hogatza belt. These placers contain substantial cassiterite (Barker and Foley 1986), but the concentrates also contain $2 \%$ to $10 \% \mathrm{REE}$, primarily monazite and xenotime.

Additional prospective host areas for REE placers occur near Indian Mountain west of Kanuti. Beach sands near the Darby Mountains are reported to contain REE (Bates and Wedow 1953), and at Cape Wales, heavy mineral beach concentrations contain monazite, xenotime, allanite with ilmenite, zircon, chromite, and cassiterite. This suggests possible offshore placers in the Bering Strait. Further testing of both locations is continuing by the USBM.

Silica-rich intrusive complexes also give rise to several relatively small deposit types or byproducts occurrence of which there are Alaska examples. Minor REE values and recoverable amounts of niobium and tantalum are associated with the tin-bearing greisens near Kougarok Mountain. The Kougarok deposits grade from $0.1 \%$ to $1.0 \%$ tin; niobium and tantalum are about $0.05 \%$ each (Puchner 1986). Present USBM studies have identified monazite and zirkelite in drill core samples (Johnson and McDonald, no date). Subvolcanic rhyolite porphyry stocks like those near Livengood can contain elevated REE and niobium values (Foster 1968). Uranium-bearing vein deposits in the Old Crow batholith, in the 
Kanuti area, and near Kook Lake on Chichagof Island contain $0.2 \%$ to $0.5 \%$ REE, nearly all as the cerium subgroup. The mineral species in these minor deposit types have not yet been identified but include monazite. Metamorphic deposits containing disseminated monazite in gneiss and migmatite similar to those in California have not yet been recognized in Alaska.

\section{Silica-Poor Deposits}

Concentrations of REE are associated with a wide range of alkaline rocks that can be divided according to the source of the lithophile metals and, to some extent, the parent magma. Although parental magmas of most alkaline igneous rocks are melts that formed deep within the upper mantle, some of the intrusive complexes also have a significant crustal component. Common, deep-mantle-derived alkaline intrusions include carbonatites, diatremes, and kimberlites. Carbonatites or carbonate enrichments occur where these melts take place in the presence of dissolved $\mathrm{CO}_{2} ; \mathrm{CO}_{2}$-rich concentrations of volatiles produced by these melts can localize highly enriched zones of certain lithophile elements preferentially precipitating the light cerium subgroup REE. Consequently, the content of mantle-derived $\mathrm{REE}$ is characterized by high cerium/ytterbium ratios. Unlike the yttrium subgroup, the light REE readily form stable carbonate and fluorcarbonate compounds (Muecke and Moller 1988; Philpotts 1985).

In contrast to magmas that clearly originate in the mantle source, some alkaline complexes experience a higher degree of intrusive interaction and volatilization during emplacement within the crust, thereby leading to concentrations of lithophile elements in a hydrous vapor phase. In this environment the light REE remain in the liquid phase, whereas the yttrium subgroup are preferentially concentrated during early crystallization (Muecke and Moller 1988). Earth's crust relative to the mantle is generally more enriched in the heavy, yttrium subgroup REE; consequently, cerium/ytterbium ratios in REE deposits from within the crust are markedly lower. The remaining light REE contained in late-stage magmatic liquids concentrate in the uppermost, often silica-rich, phases of the intrusion, and they are most commonly precipitated as monazite and allanite as previously discussed with granitic placers.

The geologic environment in which REE concentrations are formed controls the form of REE mineralogy. In Alaska, crustal-derived syenites, diorites, monzonites, and peralkaline granites host several significant polymineralic deposits anomalously mineralized with yttrium subgroup silicate and oxide minerals (such as thalenite, euxenite-polycrase, and fergusonite), as well as various cerium subgroup carbonate and fluorcarbonate minerals (such as bastnaesite, parisite, and synchysite). In comparison, the mantle-derived intrusions (carbonatite, related carbonate veins, and some diatremes) are typified by associated REE minerals that almost exclusively form as cerium subgroup carbonate and fluorcarbonate compounds. Monazite is often present but in minor amounts. Brannerite, which contains light REE oxide, is widely reported in the Yukon Territory in breccia pipes suggesting deepseated gas venting. However, their mode of emplacement and depth of origin is not well understood.

Mantle-Derived Deposits. Carbonatite and associated carbonate veins are known at a few locations in Alaska, but there has been very little, if any, exploration for this deposit type. The most promising prospect areas are carbonatite dikes related to a differentiated quartz monzonite and syenite intrusive complex at William Henry Bay (Warner 1985); at Salmon 
Bay, where low-grade cerium subgroup REE- and niobium-bearing carbonate veins contain bastnaesite, parisite, and lesser monazite (Houston et al. 1958; Warner 1988); and in a poorly exposed region containing regolith and carbonatite near Tofty (Warner, Mardock, and Dahlin 1986). The carbonatites at Tofty are low grade, but weathering and erosion have provided examples of placer REE and niobium deposits (Southworth 1984). The weathering carbonatite regolith constitutes an upgraded residual placer, and nearby alluvial streambeds contain recoverable quantities of columbite, ellsworthite, and aeschynite (Southworth 1984). In northwest Alaska, carbonate-silica veins and pods with high REE values occur in the Selawik Hills syenite, but their geologic setting and extent are unclear.

Alkaline diatremes and breccia pipes are documented in British Columbia and the Yukon Territory (Bell 1987; Pell, no date). The only presently known example in Alaska occurs at Stonerock Bay, where pipe-like syenite breccia contains xenoliths of altered carbonatite mineralized with several percent of light, cerium subgroup REE, apatite, and radioactive minerals. The REE is contained in monazite (probably secondary) occurring in disseminations and in aggregates of grains less than 10 microns in size and spatially associated with apatite. There are no occurrences of kimberlite yet reported in Alaska.

Crustal-Derived Deposits. Highly differentiated alkaline, sodic-alkaline to peralkaline syenites and riebeckite-aegirine granites on southern Prince of Wales Island (Figure 3) featured highly evolved, late-stage, concentrically zoned pegmatites and pegmatite dikes containing concentrations of REE (average minimal values of $0.45 \%$ to $1.45 \%$ REE are minimal due to analytical techniques). The dikes radiate from the intrusive complexes for distances up to four miles into the country rock and are aligned with topographic linears possibly representing preexisting fracture systems.

The REE and other lithophile elements are distinctly zoned with increasing concentrations in pegmatite dikes as distance increases from the intrusive complexes. As a whole, intrusive masses are depleted in REE and niobium relative to similar complexes elsewhere in the world. At Bokan Mountain and Dora Bay, the REE, niobium, zirconium, beryllium and other metals are most highly enriched in distal portions of pegmatite dikes. Progressing away from the intrusions, dikes grade into bifurcated sets of fine-grained vein-dikes and ultimately into veins that together cut the surrounding country rock along definable zones (Figures 4 and 5).

Recent tonnage estimates based on surficial evaluations of the Bokan Mountain and Dora Bay deposits (Figure 3) by USBM total approximately 40 million tons of inferred or indicated resources containing $0.5 \%$ or more rare-earth oxides (REO) and $0.12 \% \mathrm{Nb}_{2} \mathrm{O}_{5}$, plus potentially recoverable beryllium, tantalum, uranium, and zirconium (Barker and Mardock 1988; Warner and Barker 1988).

At least half of the REO content comprises the yttrium subgroup. Principal REE, niobium, and uranium-thorium mineralogy of the southern Prince of Wales deposits is given in Table 3.

Elsewhere, pegmatite dikes containing allanite are reported on Admiralty Island (Eakins 1975), and concentrically zoned pegmatites are common on Seward Peninsula. Additionally, known occurrences of riebeckite granite and associated sodic monzonite and syenite on Chichagof Island near Kook Lake and in southwest Alaska may host deposits similar to those at Bokan Mountain, but these areas have not yet been well explored. Placer deposits are 
also likely to occur in alluvial drainages near southwest Alaska alkaline and subalkaline complexes as indicated by heavy-mineral surveys in the region (Bundtzen, Cob, and Veach 1988). In the southwest Alaska Range, gravels derived from the peralkaline Windy Fork pluton contain REE in titanium and iron silicates and allanite associated with abundant ilmenite and zircon. Gold placers throughout the Iditarod District commonly encountered $\mathrm{REE}$, tantalum, and niobium minerals. In the Zane Hills near Hogatza, alkaline dikes reported to be of bostonite composition locally contain up to $1.5 \%$ REE with minor uranium values (Noyes 1988). However, occurrences are isolated and have no apparent resource potential.

There are several examples of epigenetic/replacement-type deposits in Alaska. The RossAdams deposits, also at Bokan Mountain, have been mined for uranium occurring as uraninite and uranothorite. Mineralization was due to hydrothermal replacement along microfractures, and the grade of direct shipping ore averaged $0.76 \%$ uranium. This deposit also contains yttrium (0.3 to $0.4 \%$ yttrium in USBM samples) but only minor amounts of other REE. Near Mount Prindle in central Alaska, the Roy Creek prospect consists of highly mineralized veins and pods cutting nepheline aegirine syenite as open-space replacement in fissures (Burton 1981). Samples contain up to 20\% REE and 9\% thorium. Mineralogy is complex and composed of britholite, thorianite, allanite, and numerous other intergrown minerals listed in Table 4. Both the cerium and yttrium subgroups are present at the Roy Creek prospect but exist at a ratio of about 8 to 1. It has been suggested the Mount Prindle area alkaline complex is displaced from similar uranium- and REE-bearing intrusive rocks in the Tombstone Mountains of the Yukon Territory (Burton 1981). In contrast to granite-hosted silica RËE veins, thorium-rich veins in the western Zane Hills (Upper Wheeler Creek) contain from 0.05 to $0.5 \%$ yttrium with only minor REE, tentatively identified as being due to xenotime. The Zane Hills are part of the alkaline Hogatza plutonic belt and are largely composed of granodiorite but include minor monzonite and syenite phases.

Metasomatic-type REE deposits are best known in association with magnetite-apatite mineralization such as at Mineville, New York (Adams and Staatz 1973). Magnetite metasomatic REE deposits have not yet been recognized in Alaska. However, at Taku Inlet, gold placer alluvial fan and beach sands contain abundant magnetite and minor apatite. Traces of apatite, pyrochlore, and monazite having chemically high levels of yttrium have been identified and may have a metasomatic source.

At the westernmost extent of the Hogatza plutonic belt, uranium, thorium, and REE mineralization of reported metasomatic deposition is related to the intrusion of pulaskite dikes into the syenite- and monzonite-bearing Kachauik pluton (Himmelberg and Miller 1980). The REE occur in vein systems cutting monzonite-syenite up to $400 \mathrm{ft}$ from the dikes. Individual veins are up to one foot thick. Samples of syenite with vesuvianite and allanite contain up to $3.9 \% \mathrm{REE}$, primarily comprising the light cerium subgroup but with slightly elevated levels of transition REE (neodymium, samarium, dysprosium). Further investigation by USBM continues.

\section{Chemically Enriched Sediments}

Very little is known about the possible enrichment of REE in chemically enriched sediments in Alaska. Deposits of phosphate rock $\left(>13.8 \% \mathrm{P}_{2} \mathrm{O}_{5}\right)$ along the north flank of the Brooks 


$$
\|
$$




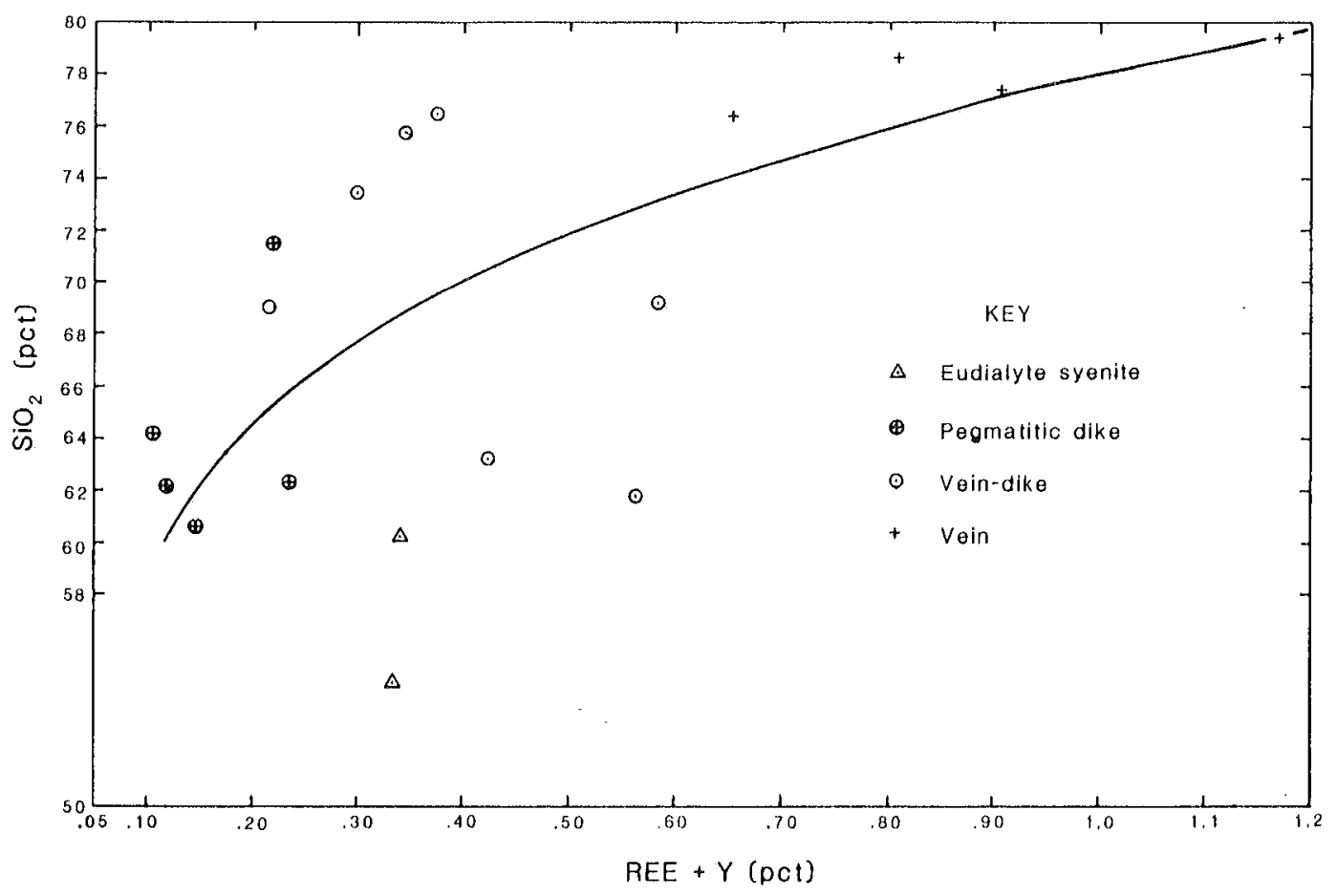

Figure 5. Zonation of silica as compared with more highly evolved lithophile-cnriched vein-dikes and veins at Dora Bay. 
Table 3. $\mathrm{REE}, \mathrm{Nb}$, and radioactive mineralogy identified in the southern Prince of Wales Island deposits.

Principle REE Minerals ${ }^{1}$.

Thalenite $\mathrm{Y}_{3} \mathrm{Si}_{3} \mathrm{O}_{10}(\mathrm{OH})$

Eudialyte $\mathrm{Na}_{4}(\mathrm{Ca}, \mathrm{Ce})_{2}(\mathrm{Fe}, \mathrm{Mn}, \mathrm{Y}) \mathrm{ZrSi}_{8} \mathrm{O}_{22}(\mathrm{OH}, \mathrm{Cl})_{2}(?)$

Tengerite $\mathrm{CaY}_{3}\left(\mathrm{CO}_{3}\right)_{4}(\mathrm{OH})_{3} 3 \mathrm{H}_{2} \mathrm{O}$

Bastnaesite (Ce, La) $\mathrm{CO}_{3} \mathrm{~F}$

Parisite $\mathrm{Ca}(\mathrm{Ce}, \mathrm{La})_{2}\left(\mathrm{CO}_{3}\right)_{3} \mathrm{~F}_{2}$

Synchysite $\mathrm{Ca}(\mathrm{Ce}, \mathrm{La})\left(\mathrm{CO}_{3}\right)_{2} \mathrm{~F}_{2}$

Yttrium bastnaesite $(\mathrm{Y}, \mathrm{Ce})\left(\mathrm{CO}_{3}\right) \mathrm{F}$

Yttrofluorite $(\mathrm{Ca}, \mathrm{U})(\mathrm{F}, \mathrm{O})_{2}$

Allanite $(\mathrm{Ce}, \mathrm{Ca}, \mathrm{Y}) 2(\mathrm{Al}, \mathrm{Fe}) 3\left(\mathrm{SiO}_{4}\right)_{3}(\mathrm{OH})$

Monazite (Ce,La,Nd,Th) $\mathrm{PO}_{4}$

Xenotime $\mathrm{YPO}_{4}$

\section{Principle Nb Minerals}

Euxenite-polycrase

series (Y,Ca, Ce, $\left.U,{ }^{\prime} \mathrm{Th}\right)\left(\mathrm{Nb},{ }^{\mathrm{T}} \mathrm{Ta}, \mathrm{Ti}\right)_{2} \mathrm{O}_{6}$

Columbite $(\mathrm{Fe}, \mathrm{Mn})(\mathrm{Nb}, \mathrm{Ta})_{2} \mathrm{O}_{6}$

Samarskite $(\mathrm{Y}, \mathrm{Cr}, \mathrm{U}, \mathrm{Fe})_{3}(\mathrm{Nb}, \mathrm{Ta}, \mathrm{Ti})_{5} \mathrm{O}_{16}$

Fergusonite (U,REE,U,Ca,Th) $(\mathrm{Nb}, \mathrm{Ta}, \mathrm{Ti})_{4}$

Aeschynite $(\mathrm{Ce}, \mathrm{Ca}, \mathrm{Fe}, \mathrm{Th})(\mathrm{ti}, \mathrm{Nb})_{2}(\mathrm{O}, \mathrm{OH})_{6}$

Principle U-Th Minerals

Thorite $\mathrm{ThSiO}_{4}$

Uranothorite $(\mathrm{U}, \mathrm{Th}) \mathrm{SiO}_{4}$

${ }^{1}$ The Y-bearing minerals may substitute significant percentages of the heavy yttrium subgroup rare-earth elements, atomic numbers 62 through 71 . The Cebearing minerals may similarly substitute significant percentages of the light cerium subgroup rare-earth elements, La, Pr, Nd, Sm, and Eu, atomic numbers 57 through 61.

Table 4. Mineralogy ${ }^{1}$ of the Mount Prindle, Roy Creek Prospect.

\begin{tabular}{|c|c|c|}
\hline Major & Minor & Trace \\
\hline Britholite & Quartz & Monazite \\
\hline Thorianite-uraninite & Xenotime & Zircon \\
\hline Allanite & Bastnaesite & Magnetite \\
\hline Feldspar & Neodyminum-phosphate & Biotite \\
\hline & Thorite & Pyroxene \\
\hline
\end{tabular}

${ }^{1}$ Petrography by Staatz,1980 and Burton, 1981 


\begin{tabular}{|c|c|c|c|c|c|}
\hline & \multicolumn{3}{|c|}{ Placers - Alaska } & \multicolumn{2}{|c|}{ Placers - Elsewhere } \\
\hline & $\begin{array}{l}\text { Old } \\
\text { Crow } \\
n=25 \\
\end{array}$ & $\begin{array}{c}\text { Kanutf } \\
n=14 \\
\end{array}$ & $\begin{array}{c}\text { Cape } \\
\text { Wales } \\
n=8\end{array}$ & $\begin{array}{l}\text { Florida2/ } \\
\text { Monazite }\end{array}$ & $\begin{array}{l}\text { Malaysia2 } 2 \\
\text { Xenotime } \\
\end{array}$ \\
\hline \multicolumn{6}{|c|}{ Light Cerium Subgroup (q) } \\
\hline $\mathrm{La}_{2} \mathrm{O}_{3}$ & 18.2 & 19.8 & 27.2 & 17.5 & 0.5 \\
\hline $\mathrm{CeO}_{2}$ & 39.8 & 36.2 & 49.5 & 43.5 & 5.0 \\
\hline $\operatorname{Pr}_{6} 0_{11}$ & 3.6 & 4.0 & & 5.0 & 0.7 \\
\hline $\mathrm{Nd}_{2} \mathrm{O}_{3}$ & 19.0 & 17.2 & 6.634 & 17.5 & 2.2 \\
\hline $\mathrm{Sm}_{2} \mathrm{O}_{3}$ & 3.3 & 2.4 & & 4.9 & 1.9 \\
\hline $\mathrm{Eu}_{2} \mathrm{O}_{3}$ & $\operatorname{Tr}$ & $\operatorname{Tr}$ & & 0.2 & 0.2 \\
\hline \multicolumn{6}{|c|}{ Heavy Yttrium Subgroup $(\%)$} \\
\hline $\mathrm{Gd}_{2} \mathrm{O}_{3}$ & 2.3 & 2.4 & & 6.6 & 4.0 \\
\hline $\mathrm{Tb}_{4} 0_{7}$ & NA & NA & & 0.3 & 1.0 \\
\hline $\mathrm{Dy}_{2} \mathrm{O}_{3}$ & 1.9 & 2.0 & & 0.9 & 8.7 \\
\hline $\mathrm{Ho}_{2} \mathrm{O}_{3}$ & 0.1 & 0.1 & & 0.1 & 2.1 \\
\hline $\mathrm{Er}_{2} \mathrm{O}_{3}$ & 1.0 & 1.5 & $2.83 /$ & $\operatorname{Tr}$ & 5.4 \\
\hline $\mathrm{Tm}_{2} \mathrm{O}_{3}$ & NA & NA & & $\operatorname{Tr}$ & 0.9 \\
\hline $\mathrm{Yb}_{2} \mathrm{O}_{3}$ & 0.8 & 1.6 & & 0.2 & 6.2 \\
\hline $\mathrm{Lu}_{2} \mathrm{O}_{3}$ & $N A$ & $N A$ & & $\operatorname{Tr}$ & 0.4 \\
\hline $\mathrm{r}_{2} \mathrm{O}_{3}$ & 9.9 & 12.8 & & 3.2 & 60.8 \\
\hline
\end{tabular}

Table 5. Rare-earth elements including yttrium content of representative crustal, silica-rich rare-earth element deposit-types (\% of total $\mathrm{REO}^{1}$ ). 


\begin{tabular}{|c|c|c|c|c|c|c|c|c|c|}
\hline & \multicolumn{2}{|c|}{$\begin{array}{c}\text { Pegmatite } \\
\text { Dikes }\end{array}$} & \multicolumn{3}{|c|}{$\begin{array}{r}\text { Concentric } \\
\text { Peamatite }\end{array}$} & \multicolumn{3}{|c|}{$\begin{array}{r}\text { Epigenetic } \\
\text { Replacement }\end{array}$} & \multirow{2}{*}{$\begin{array}{l}\text { Metasomatic } \\
\substack{\text { Kachauik } \\
n=3}\end{array}$} \\
\hline & \begin{tabular}{|l|} 
Bokan \\
$n=127$
\end{tabular} & $\begin{array}{l}\text { Dora } \\
\text { Bay } \\
n=16\end{array}$ & $\begin{array}{l}\text { Bokan } \\
\text { ILM } \\
n=10\end{array}$ & $\begin{array}{l}\text { Bokan } \\
\text { Other } \\
n-4\end{array}$ & $\underset{n=1}{S e l \text { awik }}$ & $\begin{array}{c}\text { Ross Adams } \\
\text { Sun. Lake } \\
n=10\end{array}$ & \begin{tabular}{c|} 
Roy \\
creek \\
$n=2$
\end{tabular} & $\begin{array}{l}\text { Zane } \\
H+11 s \\
n=16\end{array}$ & \\
\hline \multicolumn{10}{|c|}{ Light Cerium Subgroup $(\%)$} \\
\hline $\operatorname{La}_{2} \mathrm{O}_{3}$ & 13.9 & 7.9 & 9.3 & $\operatorname{Tr}$ & & 0.9 & 24.7 & & 33.3 \\
\hline $\mathrm{CeO}_{2}$ & 21.9 & $\mid 17.0$ & 6.4 & 12.3 & & 3.9 & 39.6 & & 35.9 \\
\hline Pr6011 & 3.7 & 3.1 & 19.7 & 7.4 & $71.63 /$ & $\operatorname{Tr}$ & 4.81 & 26 & 3.4 \\
\hline $\mathrm{Nd}_{2} \mathrm{O}_{3}$ & 14.6 & 7.8 & 23.2 & 12.9 & & 13.5 & 14.4 & & 18.8 \\
\hline $\mathrm{Sm}_{2} \mathrm{O}_{3}$ & 3.5 & 2.0 & $\operatorname{Tr}$ & $\mathrm{Tr}$ & & 3.2 & 2.3 & & 3.3 \\
\hline $\mathrm{Eu}_{2} \mathrm{O}_{3}$ & 0.6 & 5.0 & $\operatorname{Tr}$ & $\operatorname{Tr}$ & & 0.4 & 0.6 & & 0.3 \\
\hline \multicolumn{10}{|c|}{ Heavy Yttrium Subgroup (\%) } \\
\hline $\mathrm{Gd}_{2} \mathrm{O}_{3}$ & 2.0 & 4.1 & 1.3 & $\mathrm{Tr}$ & & $\mathrm{Tr}$ & 2.3 & & 0.9 \\
\hline $\mathrm{Tb}_{4} \mathrm{O}_{7}$ & $\operatorname{Tr}$ & 0.6 & $\operatorname{Tr}$ & $\operatorname{Tr}$ & & $\mathrm{Tr}$ & 0.3 & & $\mathrm{Tr}$ \\
\hline $\mathrm{Dy}_{2} \mathrm{O}_{3}$ & 5.1 & 5.5 & 8.3 & 2.8 & & $\mathrm{Tr}$ & 1.3 & & 0.6 \\
\hline $\mathrm{H}_{2} \mathrm{O}_{3}$ & 0.5 & 1.2 & 1.7 & 1.7 & & $\operatorname{Tr}$ & 0.2 & & 0.3 \\
\hline $\mathrm{Er}_{2} \mathrm{O}_{3}$ & 2.1 & 3.5 & 3.3 & 5.9 & & $\mathrm{Tr}$ & 0.6 & 74 & 0.4 \\
\hline $\mathrm{Tm}_{2} \mathrm{O}_{3}$ & 0.2 & 0.4 & 0.3 & $\mathrm{Tr}$ & $28.43 /$ & $\mathrm{Tr}$ & 0.1 & & $\operatorname{Tr}$ \\
\hline $\mathrm{Yb}_{2} \mathrm{O}_{3}$ & 1.9 & 2.3 & 3.5 & 4.5 & & 3.1 & 0.21 & & 0.1 \\
\hline $\mathrm{Lu}_{2} \mathrm{O}_{3}$ & 0.2 & 0.3 & $\operatorname{Tr}$ & $\operatorname{Tr}$ & 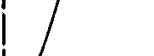 & $\operatorname{Tr}$ & $\operatorname{Tr}$ & & $\operatorname{Tr}$ \\
\hline $\mathrm{Y}_{2} \mathrm{O}_{3}$ & 29.9 & 43.7 & 23.0 & 54.0 & & 75.0 & 8.5 & & 2.8 \\
\hline
\end{tabular}

$\frac{1}{2}$ /Analyses adjusted to $100 \%$ RE0. $\frac{2}{3} /$ Data from Hedrick, 1985.

Table 6. Rare-earth elements including yttrium content of representative crustal, silica-poor, alkaline rare-earth element deposit types (\% of total REO'). 


\begin{tabular}{|c|c|c|c|c|}
\hline & Cark & tite & $\begin{array}{c}\text { Carbonate } \\
\text { Veins }\end{array}$ & $\begin{array}{c}\text { Diatremes } \\
\text { Breccia Ploes }\end{array}$ \\
\hline & Tofty & Caltfornia 2/ & $\begin{array}{c}\text { Salmon } \\
\text { Bay }\end{array}$ & $\begin{array}{c}\text { Stonerock } \\
\text { Bay } \\
n=4\end{array}$ \\
\hline \multicolumn{5}{|c|}{ Light Cerium Subgroup $(\%)$} \\
\hline $\mathrm{La}_{2} \mathrm{O}_{3}$ & & 32.0 & 32.0 & 27.0 \\
\hline $\mathrm{CeO}_{2}$ & & 49.0 & 33.8 & 41.0 \\
\hline $\operatorname{Pr}_{6} 0_{11}$ & $0 \underline{3}$ & 4.4 & 8.0 & 8.9 \\
\hline $\mathrm{Nd}_{2} \mathrm{O}_{3}$ & & 13.5 & 14.6 & 15.3 \\
\hline $\mathrm{Sm}_{2} \mathrm{O}_{3}$ & & 0.5 & 2.2 & 1.5 \\
\hline $\mathrm{Eu}_{2} \mathrm{O}_{3}$ & & 0.1 & 2.9 & 0.5 \\
\hline \multicolumn{5}{|c|}{ Heavy Yetrium Subgroup (\%) } \\
\hline $\mathrm{Gd}_{2} \mathrm{O}_{3}$ & \multirow{6}{*}{$1.03 /$} & 0.3 & 2.6 & 0.4 \\
\hline $\mathrm{Tb}_{4} \mathrm{O}_{7}$ & & $\operatorname{Tr}$ & 1.1 & 0.1 \\
\hline $\mathrm{Dy}_{2} \mathrm{O}_{3}$ & & $\operatorname{Tr}$ & $\operatorname{Tr}$ & 2.0 \\
\hline $\mathrm{H}_{2} \mathrm{O}_{3}$ & & $\operatorname{Tr}$ & $\operatorname{Tr}$ & $\operatorname{Tr}$ \\
\hline $\mathrm{Er}_{2} \mathrm{O}_{3}$ & & $\operatorname{Tr}$ & $\operatorname{Tr}$ & $\operatorname{Tr}$ \\
\hline $\mathrm{Tm}_{2} \mathrm{O}_{3}$ & & $\operatorname{Tr}$ & $\operatorname{Tr}$ & $\operatorname{Tr}$ \\
\hline $\mathrm{YD}_{2} \mathrm{O}_{3}$ & & $\operatorname{Tr}$ & 0.1 & 0.2 \\
\hline $\mathrm{Lu}_{2} \mathrm{O}_{3}$ & & 0.1 & 2.5 & 3.0 \\
\hline
\end{tabular}

$\frac{1}{2}$ Analyses adjusted to $100 \%$ REO.

2/Data from Hedrick, 1985.

Table 7. Rare-earth elements including yttrium content of representative mantle silica-poor rare-earth element deposit-types (\% of total REO ${ }^{1}$ ). 


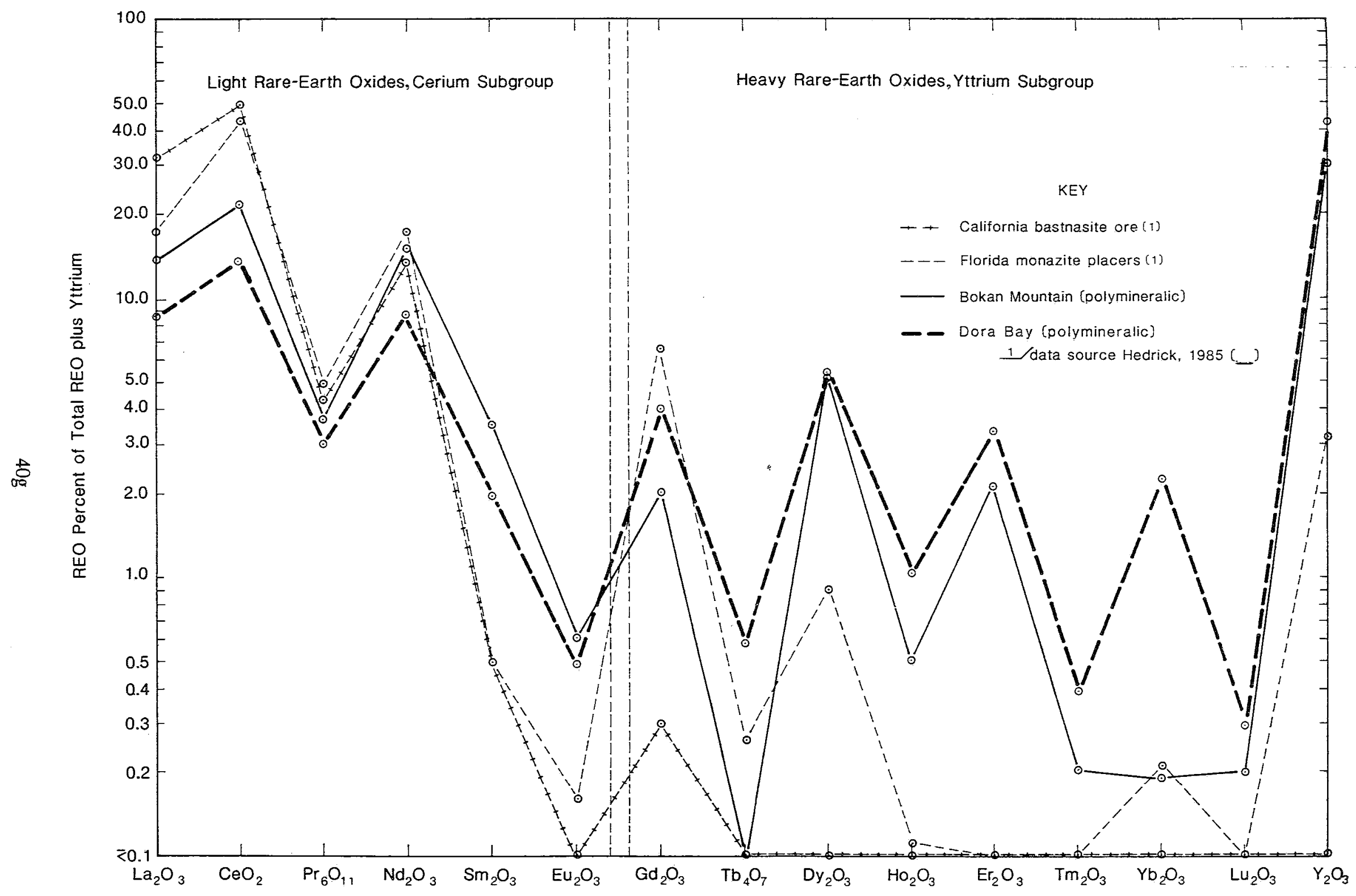

Figure 6. Percent comparison of rare-earth element distribution including yttrium in southern Prince of Wales Island deposits to California and Florida rare-earth element distribution. 


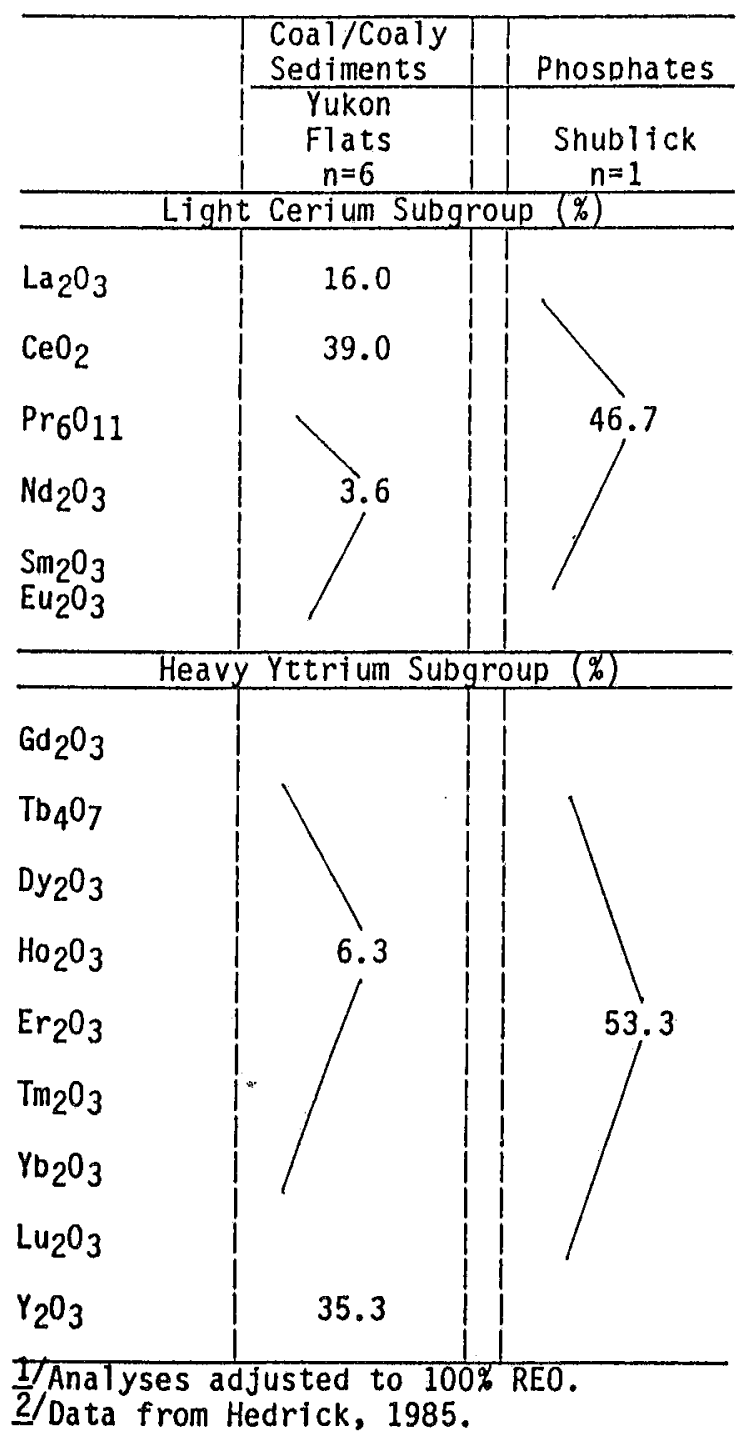

Table 8. Rare-earth elements including yttrium content of representative chemical 'sediment' rare-earth element deposit-types (\% of total REO'). 
Range are reported to contain up to $0.4 \%$ REE with yttrium predominating (Patton and Matzko 1959; Tourtelot and Tailleur 1971). No detailed sampling has been done, however, nor were the analyses done by modern analytical techniques. On the western margin of Yukon Flats, carbonaceous mudstones associated with Eocene volcanic ash and coal beds contain elevated levels of uranium, tungsten, and REE (Barker 1981b).

\section{Elemental Composition of Alaska REE Deposit Types}

As described in the introduction to this report, there is an increasing need to characterize various REE deposits on the basis of individual REE composition. In Tables 5 through 8, examples of various deposit types are presented with the quantity of each REO expressed as a percentage of the total contained REO. Each data column shows the REO distribution for individual deposits. It should be noted that the accuracy of sampling varies from one occurrence to another, and that some data are derived from older semiquantitative analytical procedures.

It is apparent from Tables 5 through 8 that the characteristic mineralogy of individual deposit types results in considerable variation of total REO composition between deposit types. Most significantly, the polymineralic pegmatite dikes (Figure 6) are shown to have higher concentrations of heavy REE due to the presence of both yttrium and cerium subgroup minerals, whereas mantle-derived deposits largely contain only cerium subgroup carbonate and fluorcarbonate REE minerals. Placer monazite deposits generally contain only $3 \%$ to $5 \%$ yttrium subgroup. However," the percentage of heavy REE can be much higher if xenotime or fergusonite is present. REE concentrates from the Kanuti and Old Crow areas reflect a combination of these minerals.

\section{Discussion}

Recent technological advances are resulting in new applications for REE and yttrium. New uses and applications for these metals are more element-specific than when REE had historically been utilized as a naturally occurring mixture. Although presently developed REE deposits worldwide are very adequate to meet present demand, many applications currently in development will require specific REE, some of which are relatively rare. Some new sources of the yttrium subgroup may be required. Most REE deposits have been described according to total REE content, irrespective of the mineralogy and individual element makeup of the REE content.

Alaska is host to REE occurrences and deposits that, as a group, represent most of the known deposit types worldwide. Some of the more significant Alaska deposits contain both cerium and yttrium REE subgroups. To date there has been no concerted exploration effort by industry toward discovery of REE deposits. Present data being collected by USBM are

only of a reconnaissance nature and are intended to provide a preliminary assessment of resource potential. Nevertheless, several deposits of possible significance are delineated. Presently known resources representing the most apparent, readily accessible tonnage potential occur both as placers associated with granitic intrusions in unglaciated terrane and as pegmatite dikes. Epigenetic/replacement-type deposits and carbonatites are also good candidates for exploration. Placer REE, generally in association with cassiterite, are most readily amenable to development. The pegmatite dikes on southern Prince of Wales Island 
are most attractive for further evaluation due to their accessible coastal location, larger size, associated by-products, lithophile metals, and higher concentrations of yttrium subgroup REE.

\section{References}

Adams, J.W., and M.H. Staatz. 1973. Rare-earth elements. Pages 547-556 in United States Mineral Resources. U.S. Geological Survey Professional Paper 820.

Barker, J.C. 1981a. Mineral investigations in the Porcupine River drainage, Alaska. U.S. Bureau of Mines OFR 27-81. 180 pp.

- 1981b. Coal and uranium investigations of the Yukon Flats cenozoic basin. U.S. Bureau of Mines OFR 140-81. 63 pp.

- 1982. Reconnaissance of rare metal occurrences associated with the Old Crow batholith. Pages 43-50 in Alaska Div. of Geological and Geophysical Surveys Report 73.

Barker, J.C., and J.Y. Foley. 1986. Tin reconnaissance of the Kanuti and Hodzana rivers uplands, central Alaska. U.S. Bureau of Mines ICC 9104. 27 pp.

Barker, J.C., and C.L. Mardock. 1988. Lithophile metal, REE-Y-Nb deposits in southern Prince of Wales Island, Alaska. Metallurgical Society of AIME, Annual Conference, Phoenix, Jan. 28, 1988. Proceedings, Process Mineralogy 8.

Bates, R.G., and H. Wedow. 1953. Preliminary summary report of thorium-bearing minerals occurrences in Alaska. U.S. Geological Survey Circular 202. 13 pp.

Bell, R.T. 1987. Megabreccias in the Werneke Mountains. Canada Geological Survey $86-1 \mathrm{~A}$.

Bundtzen, T.K., B.C. Cob, and N.C. Veach. 1988. Heavy mineral provenance studies in the Iditarod and Innoko Districts, western Alaska. Pages 221-243 in Process Mineralogy 7, The Metallurgical Society of AIME.

Burton, P.J. 1981. Radioactive mineral occurrences, Mount Prindle area, Yukon-Tanana uplands, Alaska. MS Thesis. Univ. of Alaska Fairbanks. $72 \mathrm{pp}$.

Eakins, G.R. 1975. Uranium investigations in southeastern Alaska. Alaska Div. of Geological and Geophysical Surveys. Geol. Pet. 44. 62 pp.

Foster, R.L. 1968. Potential for lode deposits in the Livengood Gold Placer District eastcentral Alaska. U.S. Geological Survey Circular 590. 18 pp.

Hedrick, J.B. 1985. Rare-earth elements and yttrium. Pages 647-664 in Mineral Facts and Problems. U.S. Bureau of Mines Bulletin 675. 
Himmelberg, G.R., and T.P. Miller. 1980. Uranium- and thorium-rich vesuvianite from the Seward Peninsula, Alaska. American Mineralogist. 65:1020-1025.

Houston, J.R., et al. 1958. Reconnaissance for radioactive deposits in southeastern Alaska, 1952. U.S. Geological Survey Bulletin 1058-A. 30 pp.

Johnson, J.L., and R.W. McDonald. No date. Tin, tantalum, and niobium recovery from Kougarok, Seward Peninsula, Alaska. U.S. Bureau of Mines OP 44-90.

Kilbourn, B. 1988. Metallurgical applications of the lanthanides and yttrium. Presentation at the Metallurgical Society of AIME, Phoenix, Jan. 1988. Proceedings in preparation, reprint available. $10 \mathrm{pp}$.

Muecke, G.K., and P. Moller. 1988. The not so rare earths. Scientific American. Jan:72-77.

Noyes, H. 1988. Written communication, Mar. 14.

Patton, Jr., W.W., and J.J. Matzko. 1959. Phosphate deposit in northern Alaska. Exploration of Naval Petroleum Reserve No. 4 and Adjacent Areas, 1944-53. U.S. Geological Survey Professional Paper 302-A. 17 pp.

Pell, J. No date. Alkaline ultrabasic rocks in British Columbia. Ministry of Energy, Mines, and Petroleum Resources OFR 1987-17. 109 pp.

Philpotts, J.A. 1985. Rare-earth concentrations in igneous rocks and ores. In X. Guangxian and X.J. Jimei, eds. New Frontiers in Rare Earth Science and Applications, Beijing, PRC.

Puchner, C. 1986. Geology, alteration, and mineralization of the Kougarok tin deposit, Seward Peninsula, Alaska. Economic Geology. 81:1775-1794.

Southworth, D.D. 1984. Columbium in the gold- and tin-bearing placer deposits near Tofty, Alaska. U.S. Bureau of Mines OFR 174-84. 21 pp.

Staatz, M.H. 1980. Written communication.

Tourtelot, H.A., and I.L. Tailleur. 1971. The Shublik formation and adjacent strata in NE Alaska. U.S. Geological Survey OFR 71-284. 62 pp.

Warner, J.D. 1985. Investigation of the William Henry Bay prospect. Unpublished field report. Available on request from J.C. Barker, U.S. Bureau of Mines, Fairbanks, AK. 30 pp.

. 1988. Columbium, rare-earth element, and thorium-bearing veins near Salmon Bay, southeastern Alaska. U.S. Bureau of Mines OFR 6-89. 25 pp.

Warner, J.D., and J.C. Barker. 1988. Columbium and rare-earth element-bearing deposits at Bokan Mountain, southeastern Alaska. U.S. Bureau of Mines OFR 33-89. 
Warner, J.D., C.L. Mardock, and D.C. Dahlin. 1986. A columbium-bearing regolith on upper Idaho Gulch, near Tofty, Alaska. U.S. Bureau of Mines IC 9105. 29 pp. 


\title{
The Mt. Prindle Area Rare-Earth Deposit
}

\author{
Jeff Burton \\ Vice President, Land and Resources \\ Bering Straits Native Corporation
}

The Roy Creek alkaline intrusive complex bearing rare-earth elements is located 95 kilometers (59 miles) north-northeast of Fairbanks, Alaska within White Mountain National Recreation Area. The Roy Creek occurrence is 27 kilometers (17 miles) west of Mt. Prindle, is bounded on the west by O'Brien Creek, and contains the headwater ridges of Roy Creek. The complex lies within the Yukon-Tanana uplands at the northern terminus of a major continuous fault system which includes Tintina Fault, Tintina Trench, and Rocky Mountains Trench. This fault system represents the late Precambrian-early Paleozoic North American continental margin. Palinspastic restoration of late Cretaceous Tintina Fault displacement juxtaposes the Roy Creek complex with the Selwyn Basin near the present position of Dawson, Yukon Territory. The Roy Creek alkaline complex may be genetically related to the lithologically similar Tombstone Mountains northeast of Dawson.

Rocks in the Roy Creek complex comprise a Cretaceous suite of syenites and a granite intruding Cambrian argillitic quartzite. Mappable igneous rock types include porphyritic biotite aegirine-augite syenite, biotite aegirine-augite syenite, aegirine-augite syenite, porphyritic biotite augite syenite, and alkali granite. There are minor occurrences of a magnetite biotite aegirine-augite lamprophyre. Biotites from aegirine-augite syenite and porphyritic biotite aegirine-augite syenite were age-dated by potassium-argon techniques at $85.4+6.4$ m.y. and 86.7+3.6 m.y., respectively.

A petrogenetic model for the Roy Creek area alkaline complex is proposed based on paragenetic sequence, field relations, and major oxide geochemistry. Due to extensive replacement of late magmatic phase mineralization visible petrographically in thin sections, the alkali granite and augite syenite are deduced to be the first magmatic products of the alkaline complex. The two rock types are found in altered and unaltered form. The aegirine-augite syenite was formed in the first phase of late magmatic processes by extensive replacement of earlier formed granite and augite syenite, and was accompanied by widespread calcite veining. In the second phase of late magmatic processes, fluorite and radioactive mineralization were deposited along fissures, and wall rocks of these fissures were altered by pervasive hematite staining. The final phase of late magmatic process in the Roy Creek area alkaline complex resulted in biotite replacing aegirine-augite. Zones of biotite replacement appear to be concentrated along airphoto lineaments which possibly represent late-stage fractures.

The post-magmatic process resulted in hydrothermal veining and alteration within and around the alkaline complex. Galena, pyrite, and magnetite were deposited in veins and veinlets after emplacement of the intrusion. Secondary potassic alteration and lamprophyre dikes occurred penecontemporaneously with hydrothermal veining in a few isolated localities within the alkaline complex.

Radioactive mineralization appears to be controlled by fissure veins. Fissures are highly inclined with pinches and swells forming openings. Faulting is evidenced by slickensides and 
bands of gouge. Mineralization appears to have filled openings by precipitation with only minor replacement of wall rock. Open vugs occur within radioactive mineralization. Hematitic alteration of wall rocks occurred in association with radioactive mineralization resulting in leaching of magnetite around radioactive mineralized fissures. This magnetite loss is measurable using surface magnetic methods.

There is an uneven distribution of values along fissures with highest grade mineralization occurring in or along contacts with pendants of altered country rocks. Samples contain up to $20 \%$ rare-earth elements and $9 \%$ thorium. Rare-earth minerals identified include (in decreasing order of abundance) britholite, thorianite-uraninite, allanite, monazite, xenotime, bastnaesite, and a new mineral tentatively identified as neodymium phosphate. Cerium and yttrium subgroups are present at the Roy Creek prospect in a ratio of 8 to 1. Rare-earth elemental abundance (in decreasing order) is cerium, lanthanum, neodymium, yttrium, praseodymium, samarium, gadolinium, and dysprosium with traces of europium, erbium, terbium, holmium, and thulium.

\section{References}

Barker, J.C. 1988. Personal communication.

Barker, J.C., and K.N. Clautice. 1977. Anomalous uranium concentrations in artesian springs and sediments in the Mt. Prindle area, Alaska. U.S. Bureau of Mines. Open File Report 130-77. 19 pp.

Burton, P.J. 1981. Radioactive mineral occurrences, Mt. Prindle area, Yukon-Tanana uplands, Alaska. M.S. thesis. Unpublished. University of Alaska Fairbanks. 72. pp.

Chapman, R.M., F.R. Weber, and B. Taber. 1971. Preliminary geological map of the Livengood Quadrangle, Alaska. U.S. Geological Survey. Open File Report 71-66. 2 sheets.

Foster, H.L., et al. 1973. Regional geology of the Yukon-Tanana upland, Alaska. Pages 388-395 in M.G. Picher, ed. Arctic Geology. American Association of Petroleum Geologists Memoir 19.

Goodfellow, M.D., and I.R. Jonasson. 1977. Geochemical distribution of uranium, tungsten, and molybdenum in the Tombstone Mountains batholith, Yukon. Pages 37-45 in Geological Society of Canada Paper 77-1b.

Vlasov, K.A. 1968. Geochemistry and mineralogy of rare elements and genetic types of their deposits; Vol. III. Pages 343-356 in Ministry of Geology of the U.S.S.R., Moscow.

Weber, F.R., et al. 1988. Geology and mineral resources of the White Mountains National Recreation Area, east-central Alaska. U.S. Geological Survey. Open File Report 88-284. 


\title{
Industrial Extraction and Purification Techniques for Rare Earths
}

\author{
Dr. R.G. Bautista \\ Mackay School of Mines \\ University of Nevada, Reno, NV
}

Introduction

This presentation will focus on processing, the extraction of rare earths from ore, bulk separation and concentration, and production of their pure oxides. There are many different minerals or ores that are used as raw material. As a result, the composition of heavy, middle, and light rare earths will vary. The well-known processes using bastnaesite and monazite will be discussed. After development of the proven ore reserve, the next step is to decide what marketable commodity to produce. One option is to simply mine the deposit and sell the ore. A second option is to beneficiate the ore to produce an ore concentrate. A third option is chemical processing of the beneficiated ore by decomposition or leaching, and separating and concentrating the rare earths in the leached solution by solvent extraction followed by precipitation and calcination to produce the different rare-earth oxides.

Beneficiation. The original Molycorp beneficiation flow sheet (Figure 1$)^{2}$ published many years ago illustrated the complexity of producing rare-earth oxides. Bastnaesite ore averages between $7 \%$ and 10\% rare-earth oxides (Baroch, Smutz, and Olson 1959; Dayton 1956). The rare-earth analysis is $50 \%$ cerium, $32 \%$ lanthanum, $4 \%$ praseodymium, $13 \%$ neodymium, $0.5 \%$ samarium, $0.1 \%$ europium, $0.2 \%$ gadolinium, and $0.2 \%$ other rare earths.

The extent of concentration and separation processing needed on a specific rare-earth deposit is dictated by the commodity to be produced. The Molycorp process produces a bastnaesite concentrate which is unleached $60 \%$ rare-earth oxide. The concentrate is produced from the ore using a beneficiation step followed by flotation.

The complex flotation process involves at least four conditioning steps with steam. In the first step, the $\mathrm{pH}$ is adjusted to 8.95 with sodium carbonate using steam to raise the slurry temperature to $140^{\circ} \mathrm{F}$. The second step raises the temperature to $180^{\circ} \mathrm{F}$ where a depressant is added. The third step raises the slurry temperature to boiling $\left(205^{\circ} \mathrm{F}\right)$ where collector and conditioning reagents are added. The fourth conditioning step is used to cool the slurry to $140^{\circ} \mathrm{F}$ for pumping to the rougher flotation circuit. The cleaner circuits are maintained at around $100^{\circ} \mathrm{F}$ by steam-heated coils. The flotation concentrate averages $60 \%$ rare-earth oxides. The tailings average $1.5 \%$ to $2.5 \%$ rare-earth oxides resulting in a recovery between $78 \%$ and $84 \%$. The bastnaesite rare-earth flotation concentrate is calcined to increase rareearth oxide concentration. A roasting step followed by a hydrochloric acid leach puts all the rare earths into solution with the exception of cerium. Cerium (III) is oxidized to cerium (IV) during roasting in air and becomes insoluble in hydrochloric acid. Filtration of the leached rare earths produces a residue rich in cerium as a cerium concentrate (Kilbourn 1989).

${ }^{2}$ Ed. Note: Figure 1 had to be deleted immediately prior to publication for proprietary reasons; numbering of the remaining figures is unchanged. 
Monazite is primarily composed of rare-earth phosphates with thorium oxide concentration around $10 \%$ and uranium oxide as high as 1\%. Monazite was the earliest source of rare earths. Beneficiation of monazite placer and beach sand deposits using dredges, jigs, shaking tables, magnetic separators, and flotation cells was recently reviewed by Aplan (1988). Monazite is also a by-product of the beneficiation of titanium and zircon sands. Xenotime, another rare-earth phosphate with predominantly heavy rare earths and yttrium, is treated in the same manner as monazite.

Leaching. The dissolution of rare earths from monazite (Figure 2) can be carried out using an acid leach or a caustic leach procedure. Bearse et al. (1954) developed a chemical process (Figure 3) for the recovery of thorium, uranium, and rare-earth oxides from monazite and the removal of nearly all the phosphates prior to dissolution of the hydrous oxide cake formed in hydrochloric acid. Finely ground monazite reduced to $96.5 \%-325$ mesh (100\% -200 mesh) reacts with liquid caustic soda containing $73 \% \mathrm{NaOH}$. The ratio of $\mathrm{NaOH}$ to sand is maintained at 1.5 , and the ratio of water to sand is maintained at 1.7. Slurry in the moderately agitated reactor is maintained at $280^{\circ} \mathrm{F}$ for three hours to complete the reaction. The reaction mixture is diluted with filter wash solution to prevent trisodium phosphate from crystallizing when the slurry temperature is lowered to $220^{\circ} \mathrm{F}$ for an additional one-hour digestion step. The metal hydrous oxides in the digested slurry are filtered from the trisodium phosphate solution and excess caustic soda at a temperature of $180^{\circ} \mathrm{F}$ under pressure. An evaporator concentrates the solutions, precipitating the trisodium phosphate and concentrating the caustic soda for recycle.

Thorium and uranium in the metal hydrous filter cake, together with the rare earths, are dissolved with $37 \% \mathrm{HCl}$ and heated to $175^{\circ} \mathrm{F}$ for one hour. The acid solution is diluted with water and partially neutralized with sodium hydroxide at room temperature to selectively precipitate all the thorium and uranium at a $\mathrm{pH}$ of 5.8. The filtrates containing about $97 \%$ rare earths as chlorides are ready for further separation and concentration or precipitation as bulk rare-earth oxides.

The sulfuric acid digestion process for monazite sand concentrates puts into solution nearly all the phosphates contained in monazite. The presence of phosphates in the solution complicates production of high-purity thorium and rare earths. Barghusen and Smutz (1957) reported a process in which $93 \%$ sulfuric acid is used to digest monazite sand to produce high yields of thorium, uranium, and rare earths; Figure 4 illustrates the chemical process steps. Monazite sand ground to at least $95 \%-65$ mesh is digested in the acid for four hours at $210^{\circ} \mathrm{C}$. The weight ratio of acid to digested sand is 1.56 based on $100 \%$ sulfuric acid. The rubber-like dough product of digestion is solubilized with $10 \mathrm{lbs}$. of cold water per pound of sand. The solubilized monazite sulfate solution filtered from the silica sludge and undigested monazite must contain 50 to 60 grams of thorium and rare-earth ions per liter of oxides, with phosphate and sulfate ions. The rare earth and thorium concentration must be closely controlled to prevent their precipitation and which on further dilution remain insoluble. The monazite sulfate solution is diluted with 4.5 parts by volume of water. The $\mathrm{pH}$ is adjusted to 1.5 with concentrated ammonium hydroxide. A $10 \%$ solution of oxalic acid is used to precipitate rare-earth and thorium oxalates. The uranium remains in solution. The sulfate and phosphate ions also remain in solution. Further concentration and purification can be carried out for each of the product streams by ion exchange or solvent extraction on fractional crystallization. 
Table 1. Mixer-settler extractor operating conditions. Reference 35.

\begin{tabular}{rrrrrr}
\hline & & & \multicolumn{2}{c}{ Flow Rates, MI per MIn } \\
\cline { 5 - 6 } Run & $\begin{array}{c}\text { No. } \\
\text { Stages }\end{array}$ & $\begin{array}{c}\text { Feed } \\
\text { Stage }\end{array}$ & $\begin{array}{l}\text { 2.64 Molar } \\
\text { RECls }\end{array}$ & HCl* & $\begin{array}{c}\text { O.5 Molar } \\
\text { D2EHPA }\end{array}$ \\
\hline & & & & & \\
1 & 10 & 7 & 6.13 & 92 & 186 \\
2 & 10 & 7 & 7.15 & 83.5 & 186 \\
4 & 10 & 7 & 5.80 & 92 & 186 \\
5 & 10 & 7 & 3.92 & 92 & 203 \\
6 & 10 & 7 & 3.63 & 92 & 203 \\
7 & 10 & 7 & 6.30 & 92 & 203 \\
8 & 10 & 7 & 3.70 & 92 & 203 \\
9 & 10 & 7 & 3.57 & 46 & 203 \\
10 & 10 & 7 & 3.54 & 92 & 254.7 \\
11 & 20 & 13 & 4.61 & 92 & 203 \\
12 & 20 & 15 & 4.52 & 92 & 203 \\
14 & 20 & 15 & 4.20 & 92 & 254.7 \\
15 & 20 & 15 & 4.34 & 114 & 203 \\
\hline
\end{tabular}

- 0.2 molar $\mathrm{HCl}$ used in runs 1-5, 0.1 molar $\mathrm{HCl}$ used in runs 6-15.

Reprinted with permission from Society for Mining, Metallurgy, and Exploration, Inc. Littleton, Colorado.

Table 2. Compositions (mole \%) of steady-state raffinate products and lanthanum recoveries. Reference 35.

\begin{tabular}{|c|c|c|c|c|c|c|c|}
\hline Run & $\mathrm{LaCl}_{3}$ & $\mathrm{NdCl}_{\mathbf{i l}}$ & $\mathrm{SmCl}_{\mathbf{i}}$ & $\mathbf{P r C l}_{\mathbf{i}}$ & $\mathrm{CeCl}_{\mathrm{il}}$ & $\mathbf{G d C l}_{\mathbf{i}}$ & $\begin{array}{l}\text { \% Lantha- } \\
\text { num Re- } \\
\text { covery In } \\
\text { Rafinate }\end{array}$ \\
\hline $\begin{array}{c}1 \\
2 \\
4 \\
5 \\
6 \\
7 \\
8 \\
9 * \\
10^{*} \\
11^{*} \\
12^{*} \\
14^{*} \\
15 * \\
\text { Feed } 1 \\
\text { FFeed } 2\end{array}$ & $\begin{array}{l}62.2 \\
60.7 \\
63.5 \\
77.8 \\
88.8 \\
70.6 \\
87.9 \\
75.3 \\
89.3 \\
92.0 \\
92.4 \\
95.4 \\
97.0 \\
44.9 \\
45.6\end{array}$ & $\begin{array}{r}18.8 \\
19.9 \\
18.0 \\
9.5 \\
3.4 \\
13.1 \\
3.9 \\
12.0 \\
4.0 \\
1.9 \\
2.0 \\
1.0 \\
0.0 \\
28.0 \\
30.5\end{array}$ & $\begin{array}{l}0.0 \\
0.0 \\
0.0 \\
0.0 \\
0.0 \\
0.0 \\
0.0 \\
0.0 \\
0.0 \\
0.0 \\
0.0 \\
0.0 \\
0.0 \\
3.8 \\
3.6\end{array}$ & $\begin{array}{l}6.3 \\
6.9 \\
6.2 \\
3.8 \\
1.9 \\
5.6 \\
2.0 \\
4.3 \\
2.0 \\
1.6 \\
1.6 \\
1.0 \\
1.0 \\
8.8 \\
8.0\end{array}$ & $\begin{array}{r}12.3 \\
12.5 \\
12.4 \\
8.7 \\
5.8 \\
10.7 \\
6.2 \\
8.4 \\
4.8 \\
4.5 \\
4.1 \\
2.7 \\
2.1 \\
11.7 \\
10.0\end{array}$ & $\begin{array}{l}0.0 \\
0.0 \\
0.0 \\
0.0 \\
0.0 \\
0.0 \\
0.0 \\
0.0 \\
0.0 \\
0.0 \\
0.0 \\
0.0 \\
0.0 \\
2.2 \\
2.4\end{array}$ & $\begin{array}{l}91.4 \\
94.1 \\
85.5 \\
84.5 \\
59.4 \\
78.8 \\
57.0 \\
69.3 \\
48.1 \\
64.0 \\
63.0 \\
48.9 \\
59.8\end{array}$ \\
\hline $\begin{array}{l}\text { Feed } 1 \\
+ \text { Feed } 2\end{array}$ & $\begin{array}{l}(2.64 \\
(2.63\end{array}$ & $\begin{array}{l}\text { olar } \\
\text { olar }\end{array}$ & $\begin{array}{l}\left.\mathrm{Cl}_{3}\right) \\
\left.\mathrm{Cl} \mathrm{l}_{3}\right)\end{array}$ & & & & \\
\hline
\end{tabular}

Reprinted with permission from Society for Mining, Metallurgy, and Exploration, Inc. Littleton, Colorado. 


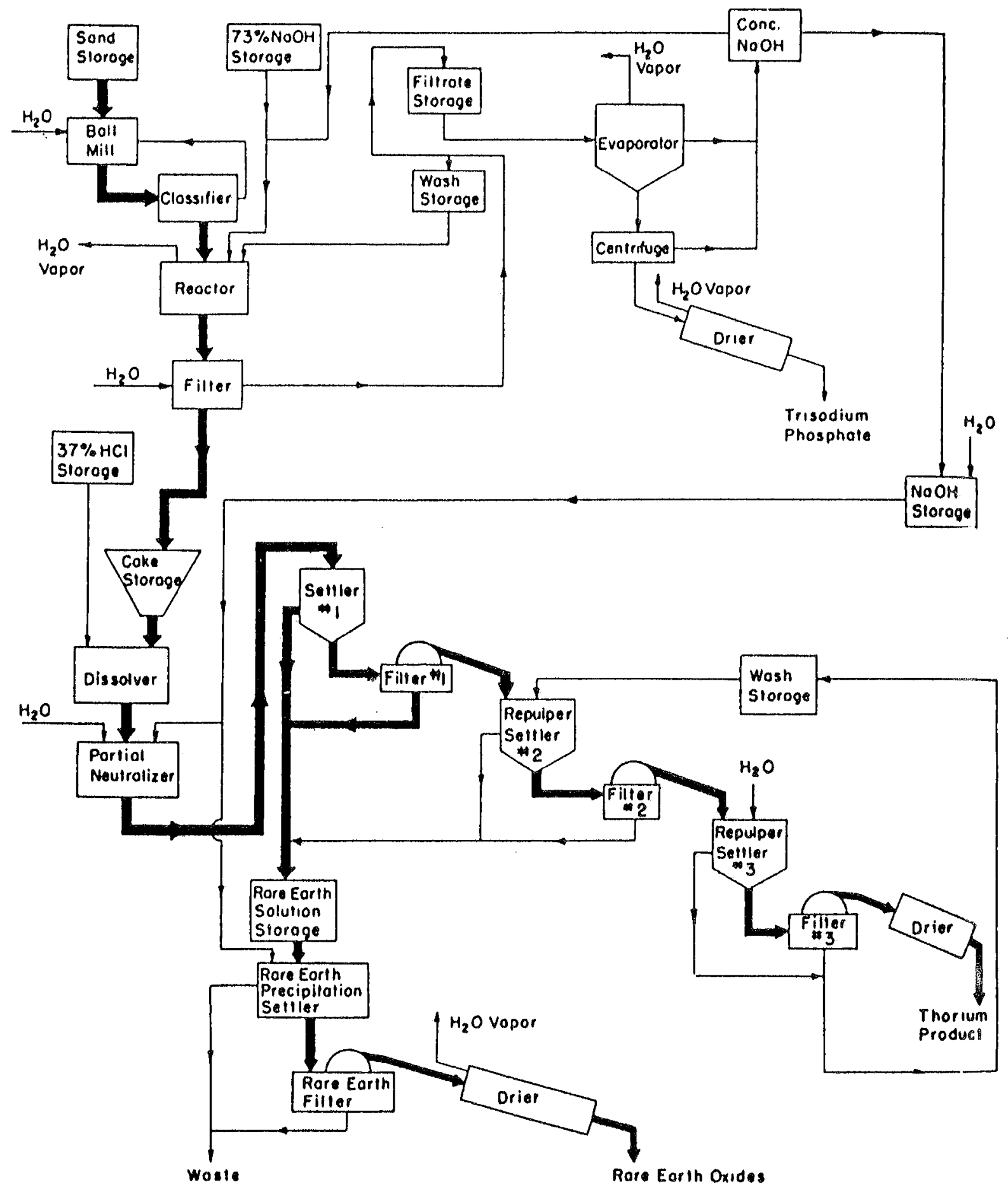

Figure 2. Flowsheet for the recovery of thorium, rare earths, and trisodium phosphate from monazite by caustic digestion. Reference 6. 
Separation and Concentration. Until the 1960s, the most widely employed rare-earth separation methods until the sixties were oxidation-reduction, hydrolysis, fractional precipitation, and crystallization. The rare-earth mixtures obtained from the leaching step with either acid or base (cerium-free) can be precipitated with aqueous or gaseous ammonia as shown in Figure 4. Krumholz et al. (1958) found that the efficiency of separation of rare earths was better in chloride solutions at a low temperature compared to nitrate solutions which form weak complexes with rare-earth ions. The precipitated basic chlorides were found to be very voluminous and difficult to filter. It was necessary to add small concentrations of low molecular weight carboxylic acids, such as acetic acid, to the precipitating agents to produce very dense and easily filterable precipitates. This precipitation method does not produce high purity rare-earth products, but it can produce a mixture of rare-earth groups that are adjacent to each other in the periodic table. Further separation by other techniques, such as double sulfate precipitation, double chromate precipitation, fractional crystallization of double nitrates, valence changes, and ion exchange are needed in order to upgrade the concentration of rare earths.

Solvent Extraction. In the Molycorp solvent extraction process (Harrah 1967) (Figure 5), high-purity europium and yttrium oxides are produced together with a cerium hydrate product; a lanthanum, praseodymium, and neodymium concentrate; and a samarium and gadolinium concentrate. These higher purity mixtures of adjacent rare-earth mixtures are the feed materials for further separation and concentration processing to produce their separated high-purity oxides. Molycorp is a major supplier of high-purity rare-earth products. No up-to-date flow sheets have been published by Molycorp.

The cerium concentrate is mostly cerium oxide with some praseodymium, neodymium, and lanthanum. The cerium concentrate contains at least 5\% to $10 \%$ other rare-earth oxides illustrating the complexity of producing a high-purity rare-earth oxide product for optical or electronic use. A major separation process is necessary to produce each one of the rareearth elements present or its oxides.

The reactors favored in solvent extraction separation of rare earth are the mixer-settlers. The total number of actual stages required for a given separation is much more than the theoretical number of stages because of the efficiency factor. No matter what the plant capacity, a small plant and a big plant will both require the same number of stages to produce a specified purity product from a given feed material. The plant must have process control and instrumentation so that a high-quality product can be produced every day.

The refined rare-earth oxide product can have a purity of $99 \%, 90 \%$, or $96 \%$ depending on the extent of chemical separation employed. The resulting different concentration of impurities have a significant effect on the product marketability and profitability. For example, the market for samarium is profitable, but in order to maximize samarium recovery from the concentrate ore the processing procedure during the solvent extraction stage of the light rare earths must be optimized. Having previously separated cerium in the +4 valence state, one can proceed with the solvent extraction separation of lanthanum, praseodymium, neodymium, and samarium. Their oxides are produced by precipitation as oxalates of the concentrated stripped solutions derived from the extract phases of the above four solvent extraction circuits. The specific rare-earth oxide products could contain as high as $90 \%$ rare-

${ }^{3} \mathrm{Ed}$. Note: Figure 5 had to be deleted immediately prior to publication for proprietary reasons; numbering of the remaining figures is unchanged. 
earth oxide. The lighter atomic weight rare-earth solvent extraction circuits are necessary to produce a high-purity middle rare-earth product. In addition, the individual middle rareearth circuit must be on line to produce a high-purity heavy rare-earth oxide.

The Rhone-Poulenc company is one of the oldest suppliers of rare earths and processes all types of rare-earth ores including monazite, bastnaesite, and xenotime. Their rare-earth ores are obtained from all over the globe, and their principal ore is monazite. This French company's rare-earth operations is part of their Fine Chemicals Division. They have a processing plant in Freeport, Texas in addition to the main plant in La Rochelle, France (Apgar and Poirier 1976; Kaczmarek 1980). The outline of the Rhone-Poulenc refining flow sheet is shown in Figure 6, indicating the high-purity rare-earth oxide concentrations obtainable in their processing.

The digestion step for ground monazite ore is done with sodium hydroxide in an autoclave. Phosphates in the ore are separated as trisodium phosphate. Rare-earth hydroxides are separated from thorium and other radioactive components by reaction with either nitric or hydrochloric acid solution depending on the separation scheme used. The chloride medium circuit produces non-separated rare-earth compounds (cerium oxides) and dehydrated rareearth chlorides which are the feed to the electrolytic production of mischmetal.

The nitrate medium circuit separates and concentrates individual rare-earth oxides to highpurity level. Other radioactive components are further removed during this step resulting in final rare-earth products that are comparable to those produced from nonradioactive rareearth ores. The cerium (IV) materrial is separated from other rare earths during the neodymium-samarium separation. Additional separation methods are employed when phosphor grade yttrium oxide or optical grade lanthanum oxide are produced to meet specifications at the ppm level for ferrous oxide, calcium oxide, or silicon oxide. Liquidliquid extraction schemes for the different rare-earth oxide circuits are carried out using mixer-settler units. The La Rochelle plant has a capacity of around 5,000 tons of rare-earth oxides and operates more than one thousand stages of mixer-settler reactors. The mixersettler units are highly automated requiring very few skilled operators. Many of the separations require a minimum of 50 stages to attain a purity of $99.99 \%$ to $99.999 \%$. The mixer-settler unit is very flexible, and a stage can be stopped without disturbing the equilibrium of different phases.

Ion Exchange. Between the mid 1950s and late 1960s, ion exchange was used commercially to separate and mass produce high-purity rare earths (Labine 1959). The ion exchange process is based on original work done by Powell and Spedding (1959a, 1959b).

Separation is based on stability constants of the different rare-earth ethylenediaminetetraacetic acid (EDTA) complexes formed and their ability to displace ammonia or hydrogen ions in the solvent (eluting agent) used to elute the resin bed. The rare-earth stability constants increase with increasing atomic number. The rare earth with a higher stability constant readily displaces that with a lower stability constant. In practice, the rare-earth chloride mixture is first loaded on a sulfonated polystyrene cation exchange resin. The solvent EDTA elutes the ion exchange column (bed) with the rare earths on the resin changing places with ammonia or hydrogen groups in the solvent molecule. After an almost infinite number of exchanges between column and solvent, the most stable rare earth is concentrated in the first portion of the solvent, and the following portions of solvent contain 


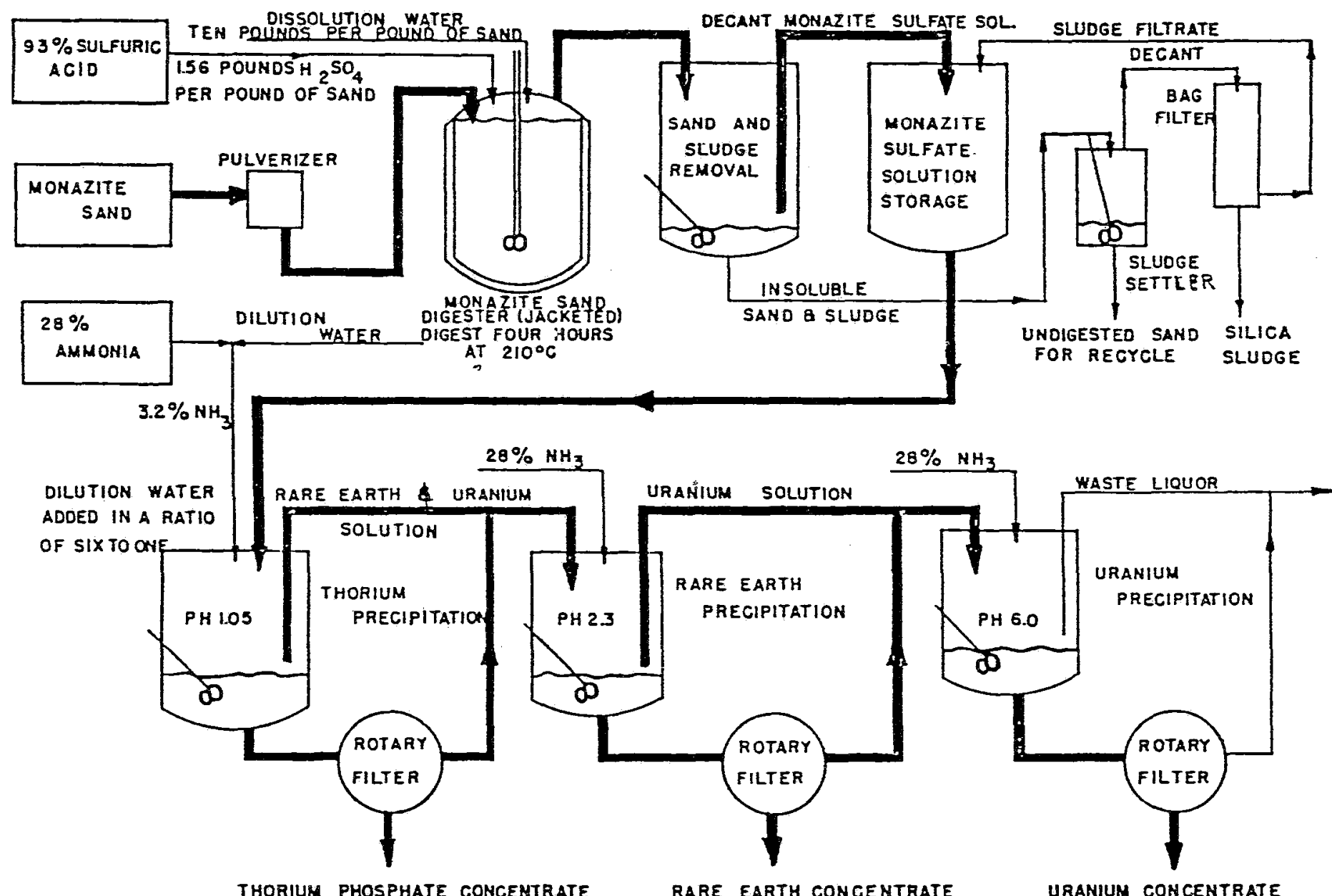

Figure 3. Flowsheet for the selective precipitation of thorium, rare earths, and uranium concentrates from sulfuric acid digestion. Reference 7. 


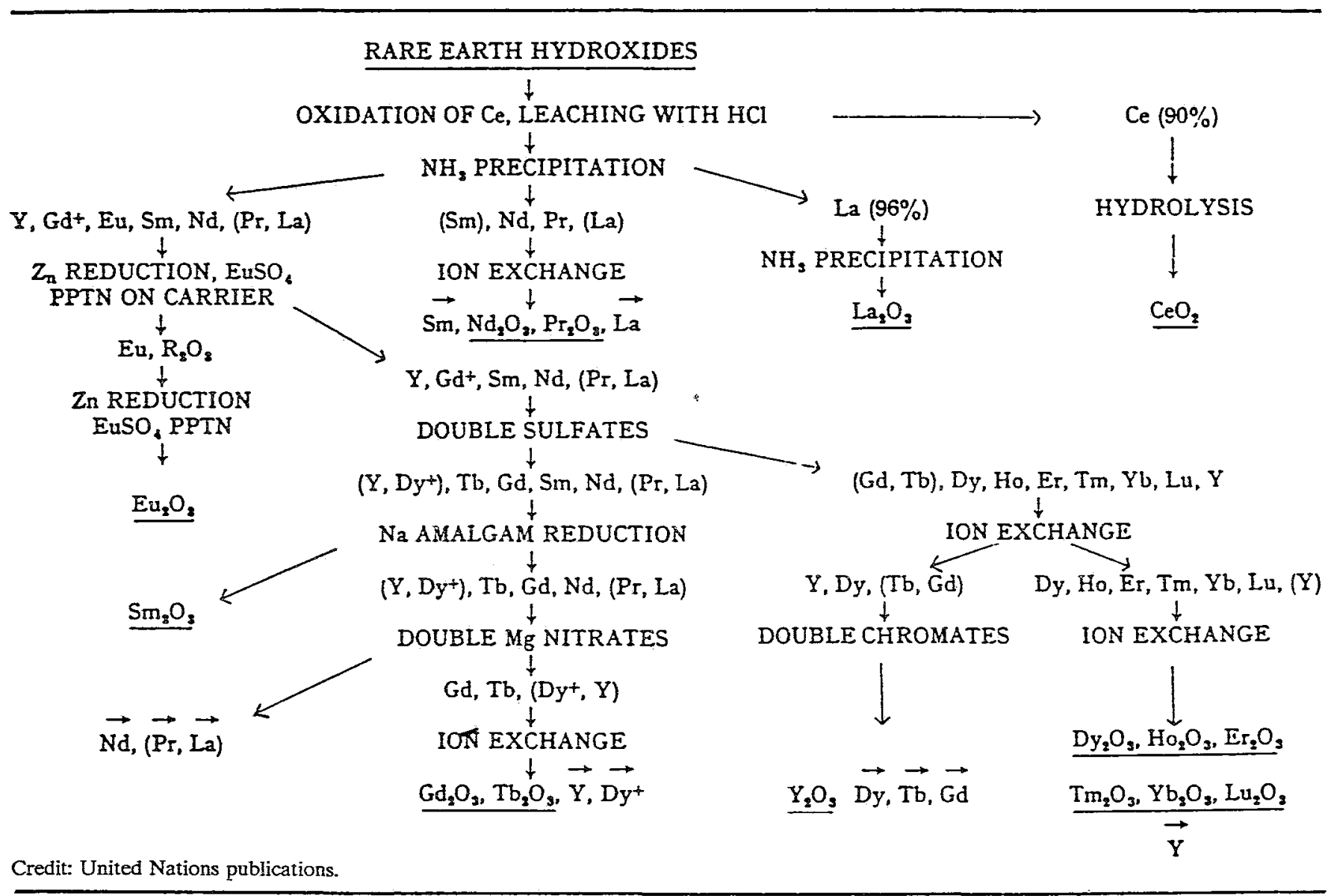

Figure 4. Flowsheet for the separation of rare earths by oxidation, reduction, hydrolysis, precipitation, and ion exchange. Reference 8. 
the other rare earths arranged in bands according to decreasing values of their stability constants.

To improve separation, solvent loaded with rare earth flows into resin beds loaded with copper ions from a copper sulfate solution. The copper EDTA complex, being more stable than any of the rare earths' EDTA complex, replaces the rare earths in the solvent molecule, thus repeating the selective deposition-elution cycle. After flowing through a batter of copper-loaded columns, the first effluent solvent contains copper ions, followed by rare earths arranged in sharp bands according to stability constants. The appearance of a new element in the effluent is the signal to start accumulating it in a new vessel to maintain its purity. Figure 7 illustrates the elution process in the preparation of high-purity rare earths. It takes approximately five to six months from the time the mixed rare-earth chlorides are charged into the system before the rare-earth product exits the ion exchange columns with more than $99 \%$ purity. The ion exchange process is still in use to produce special highpurity rare earths for special applications.

Large-scale production of separated rare earths by liquid-liquid (solvent) extraction was pioneered by Molycorp and Rhone-Poulenc. The high-purity rare earths produced by liquidliquid extraction can be further purified by ion exchange to meet the required ultra-highpurity specifications. Yttrium has been produced to the same purity level obtainable by ion exchange. The introduction of phosphorus-based reagents, tributylphosphate (TBP), and di-2-ethylhexylphosphoric acid (HDEHP) made practical the application of liquid-liquid extraction to the separation of rare earths.

Separation Factors. Peppard et al. (1953) found that the average separation factor for adjacent rare earths averaged 1.6 for light-to-middle and 1.3 for middle-to-heavy rare earths in pure TBP and 15.6 M nitric acid as the aqueous phase. In 1957, Peppard et al. (1957) reported a separation factor of 2.5 for adjacent rare earths using HDEHP as an extractant in chloride media, higher than any other extractant. The HDEHP was found to exist as a dimer in nonpolar diluents such as kerosene (Peppard and Mason 1963). The rare earths were found to extract more favorably in a chloride medium than in nitrate or sulfate systems.

The important parameters in all these liquid-liquid separations are the distribution coefficients and the resulting separation factors of adjacent rare earths. The distribution coefficient changes with temperature (Fidelis 1970; Fidelis 1971). If the plant were located where temperature gradients are extreme, it would severely affect separation if the plant were not kept at the same temperature all year. The rare-earth liquid-liquid extraction process is a two-phase system consisting of an acidic aqueous phase and an organic solvent phase that have been mixed and then allowed to settle to disengage the two phases. The distribution coefficient for a rare earth is its concentration in the organic phase divided by its concentration in the aqueous phase. In a multicomponent feed solution, the distribution coefficient for the second, third, and $n$th component must also be experimentally determined.

The parameter defining separation of a rare earth from an adjacent rare earth in the series is the separation factor. This is the ratio of the distribution coefficients of adjacent elements and is normally written to be greater than one. The separation factor essentially determines the number of stages required for a given operation. In the petroleum industry, separation factors between organic compounds are in the range of hundreds and thousands. For rare earth separation using HDEHP in chloride medium, the average separation factor is around 2.0. This is the reason that the number of separation stages for a given rare-earth processing 
circuit numbers in tens or hundreds. A very small change in the separation factor could mean one or several additional stages depending on the produce purity specified. Rare-earth concentrations in the feed solution also influence the resulting number of stages required to carry out separation and concentration. (See also Page 9, Figures 16 and 17, of Gschneidner for another discussion of the separation factor.)

The organic phase consists of the complexing reagent for the rare earths (TBP or HDEHP), a diluent (mixed aliphatic and aromatic compounds such as kerosene) for the complexed organic phase to lower organic phase viscosity, and modifiers (such as long-chain alcohols) to prevent formation of third phase or to improve the rate of extraction.

The increase in distribution coefficient with atomic number in the rare earth series and the distribution coefficient dependence on aqueous acid concentration are the important considerations in development of a separation flow sheet for each rare-earth circuit. A dilute nitric acid concentration results in a very low distribution coefficient. Using concentrated nitric acid (18.5 molar) is very expensive, very corrosive, and very difficult to handle. The acid concentration is usually maintained at 5 to 10 molar. The goal is to optimize cost versus separation efficiency. Thus acceptable costs define processing conditions and materials of construction.

The market for rare earths depends largely on technological developments. At present, the market for both neodymium and samarium is strong but not as strong for praseodymium. Both neodymium and samarium are used in high-intensity magnets. These adjacent rare earths must be separated from each other in order to market neodymium or samarium or both. If only neodymium is in demand, samarium must still be produced and stored. Praseodymium must be separated from neodymium and stored if market demand is not as strong.

Yttrium has a strong stable market. To produce high-purity yttrium, it is best to begin with xenotime ore which contains as much as $60 \%$ yttrium. To produce yttrium from monazite, which contains about $2 \%$ yttrium, involves separating all the light, middle, and heavy rare earths before any yttrium can be produced.

Separation factors for the rare-earth chlorides in HDEHP are slightly higher than in the rare-earth nitrates. Although perchloric acid separation factors are better, safety considerations have kept it from large-scale application (Pierce and Peck 1963). The separation factor depends mainly on initial rare-earth concentrations, the aqueous phase medium (nitrate, sulfates, or chlorides), the complexing reagent (HDEHP or TBP or amines) and its concentration, the diluent, the modifier, synergism with a second complexing reagent, the acidity of the aqueous phase, and the temperature.

The increase in distribution coefficients with increasing atomic number in the rare-earth series, and the distribution coefficients' dependence on aqueous acid concentrations are used in the development of a separation circuit for each individual rare earth. Experimental separation factor data on equilibrium extraction of rare earths in TBP and HDEHP in nitrate, chloride, and perchlorate media have been reported in the literature (Battista, Mize and Smutz 1966; Goto 1968; Goto and Smutz 1965a, 1965b; Gray and Smutz 1966; Hoh and Bautista 1979a, 1979b; Ioannou, Smutz, and Bautista 1972; Lenz and Smutz 1968; Michelsen and Smutz 1971; Owens and Smutz, 1968; Thomas and Burkhart 1974; Thomas, Smutz, and Burkhart 1971). 


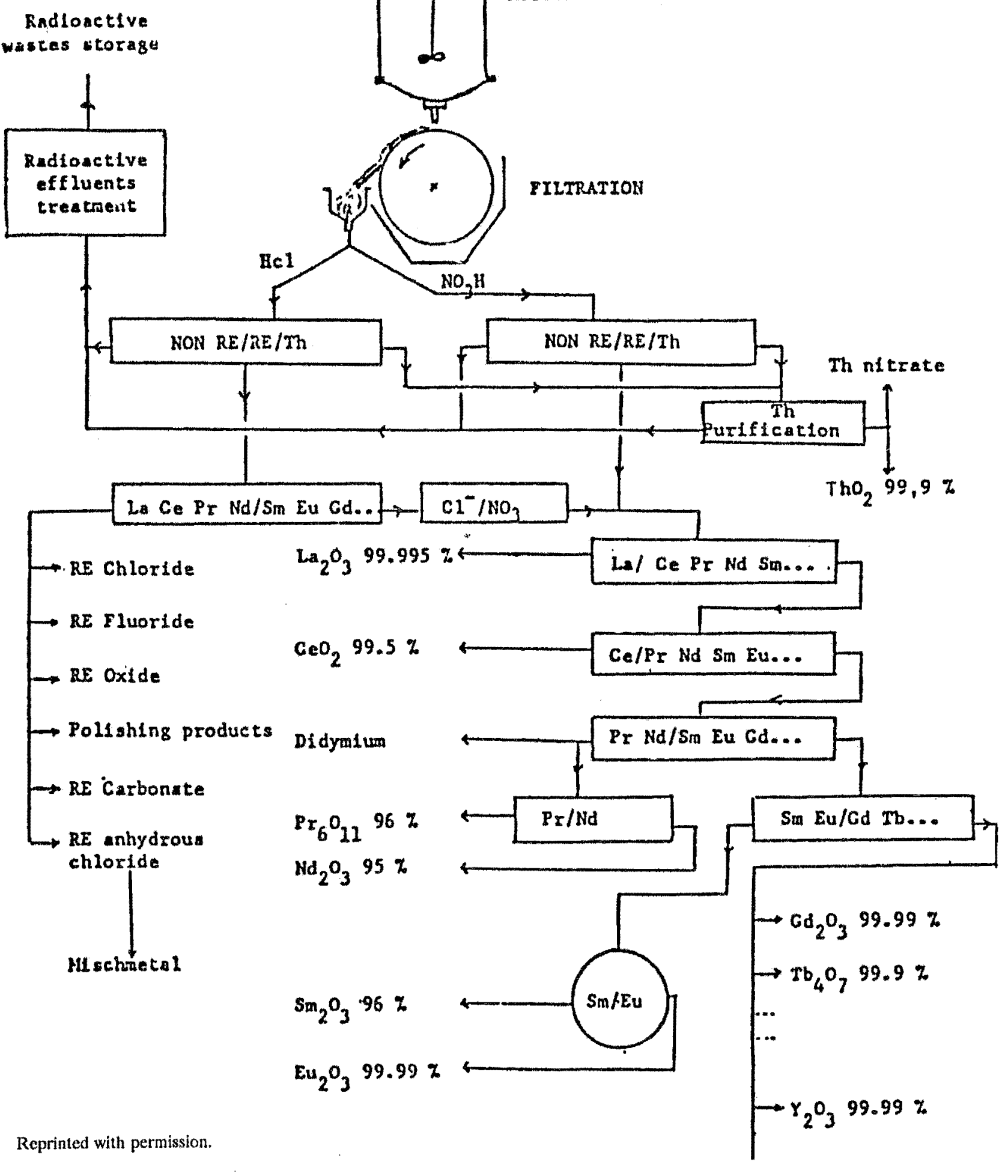

Figure 6. The Rhone-Poulenc La Rochelle flowsheet for the separation of rare earths. References 10, 11. 


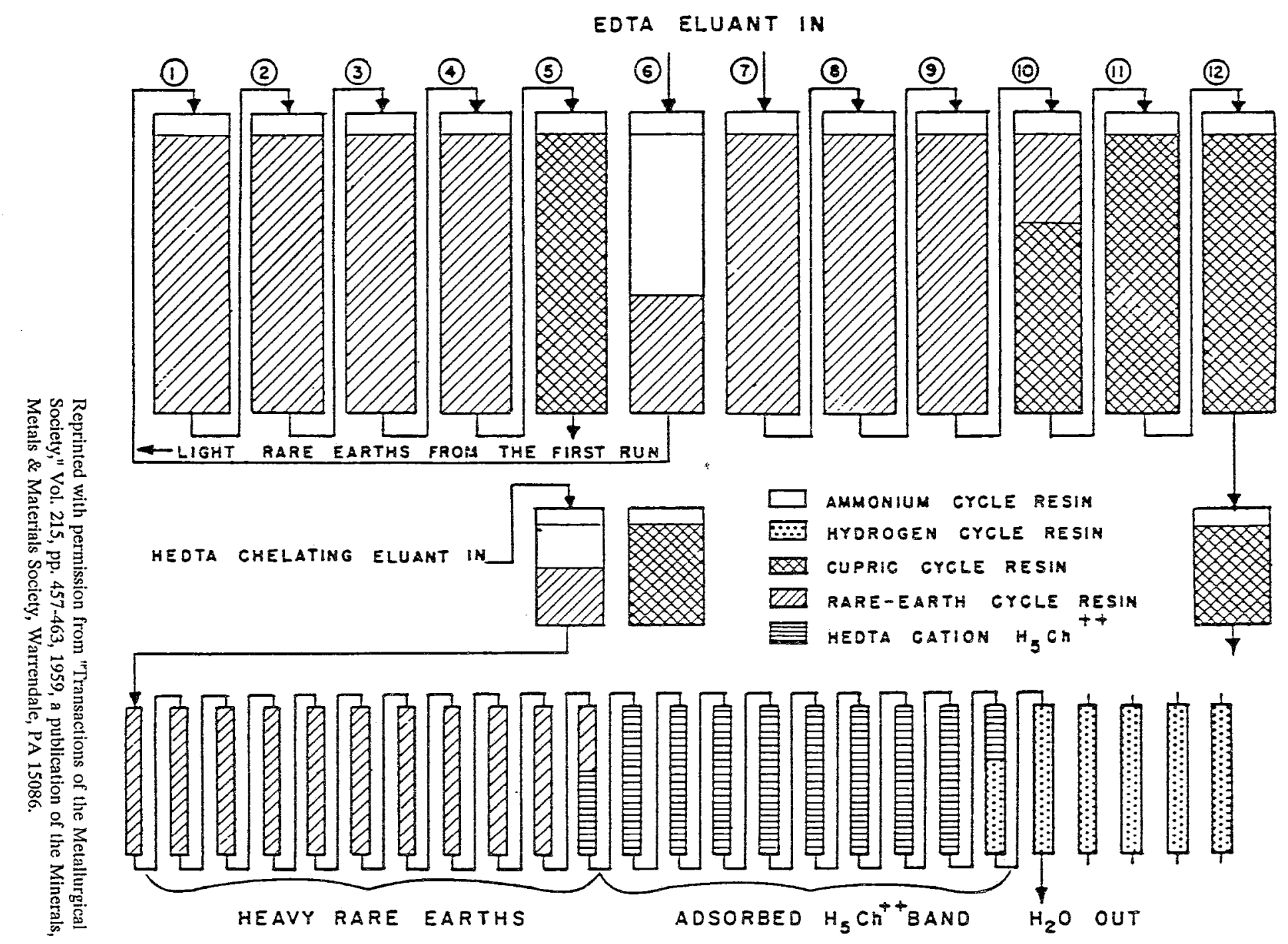

Flow diagram of the elution procedures used in isolating pure rare earths. The first band of rare earths, from which the front and rear portions have been diverted, occupies columns 7 to 10 of the main 30 -in. set. A new rare-earth band has been adsorbed on columns 1 to 4 and column 5 has been regenerated to the cupric cycle. The EDTA eluant is entering column 1 via column 6 so that the light-rare-earth fraction from the first run is being combined with the lightrare-earth fraction from the second run. The heavy-rare-earth fraction from the first run, which was isolated on the first short auxiliary column by EDTA elution, is now being eluted down a series of 6 -in. diam resin beds with HEDTA. The retaining ion on the smaller columns is $\mathrm{H}^{+}$instead of $\mathrm{Cu}^{\text {f+ }}$ (see text for details about $s$ witching eluants).

Figure 7. The elution flow diagram of the Ames Laboratory Ion Exchange Process for the concentration and purification of rare earths Reference 14. 


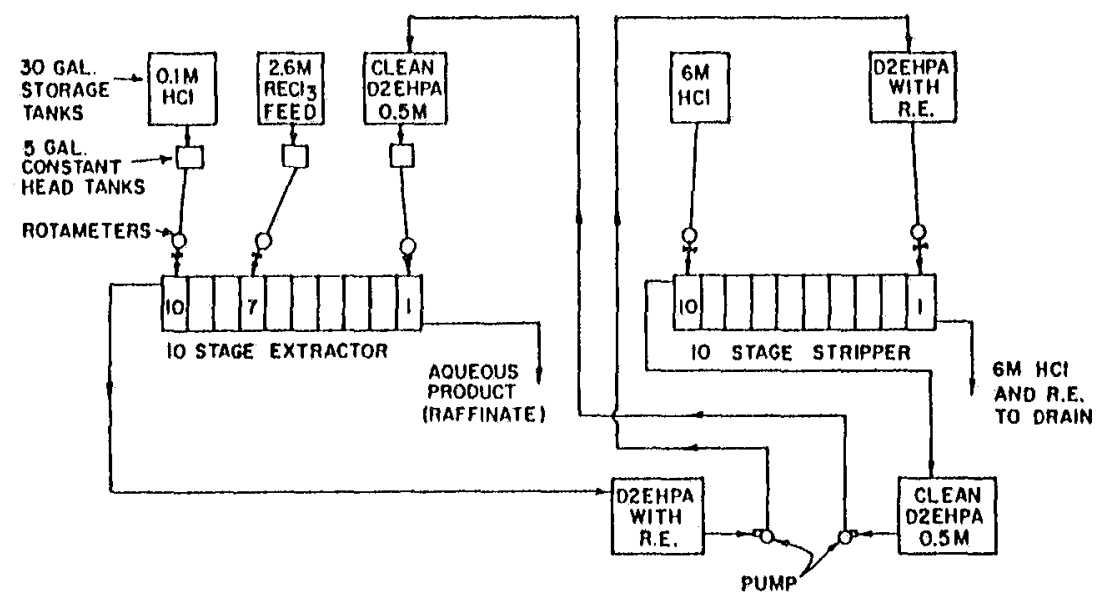

Figure 8. Fow diagram of the multistage extraction of lanthanum from a rare-earth chloride mixturc. Reference 35.

Reprinted with permission from Society for Mining, Metallurgy, and Exploration, Inc. Littleton, Colorado. 


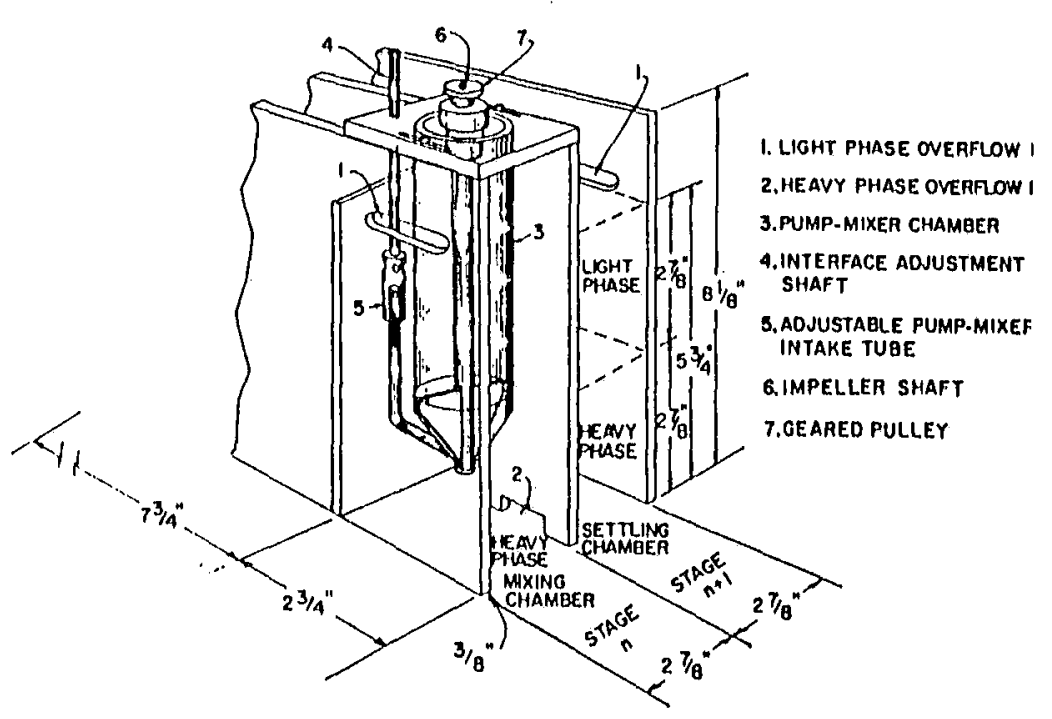

Figure 9. The cut-away section of a laboratory pump-mix mixer-settler stage. Reference 35.

Reprinted with permission from Society for Mining, Metallurgy, and Exploration, Inc. Littleton, Colorado. 
Multistage Contractors. The number of stages needed for a specific separation can be determined using fundamental chemical engineering calculations (Treybal 1963). The two pieces of information needed are the equilibrium extraction curve and the operating line. The equilibrium curve is a plot of concentration of metal in the organic phase (ordinate) versus concentration of metal in the aqueous phase (abscissa). These data can be experimentally obtained from separatory funnel equilibration of the organic- and aqueousphase rare-earth mixture. The metal concentration in each phase is analyzed. The ratio of metal concentration in the organic to the aqueous phase is the distribution coefficient. The operating line is specified by the ratio of volume of the aqueous phase in contact with the organic phase. The ratio of their flow rates in a continuous countercurrent-staged extraction is usually used. A typical value of the organic to aqueous ratio is about 1 to 3 .

The McCable-Thiele graphical method is usually used to determine the number of separation stages required for a specific system. Making material balance calculations from stage to stage is the best method. The theoretical number of stages is obtained when the specified extract (organic) and raffinate (aqueous) concentrations coming out of the last stage meets specifications.

A bench-scale continuous countercurrent two-stage mixer-settler extraction circuit was used by Casto, Smutz, and Bautista (1971) to produce a 95 to 97 mol percent pure lanthanum raffinate product with $48.9 \%$ to $59.8 \%$ recovery. The complexing reagent was 0.5 molar purified HDEFIP in an aliphatic naphtha as diluent. The feed solution was 2.64 molar rareearth chloride (RECl), and the scrub solution was 0.1 molar hydrochloric acid $(\mathrm{HCl})$. The schematic flow diagram of the 10-stage extraction and the 10-stage stripping circuits are shown in Figure 8. The extract (organic) phase coming out of the tenth stage in the extractor circuit contains most of the other rare earths and some lanthanum. The raffinate (aqueous) phase coming out of the first stage in the extractor circuit is rich in lanthanum, since lanthanum is the least extractable component from the aqueous stream.

Figure 9 details the pump-mixer-settler with the interface control tube which regulates the interface position of the organic-aqueous phase in the adjacent settling chamber. The boxtype mixer-settler is divided into a mixing chamber and a settling chamber. There are no transfer lines between stages in this design. Instead, overflow and underflow ports between adjacent stages and the pump-mixer overflow discharge tube provide all fluid transfer in the mixer settler.

Table 1 shows operating conditions for the different extraction runs. Table 2 is a composition analysis of raffinate products and lanthanum recoveries, and feed compositions. The best that the 10-stage extraction circuit can produce is 89.3 mol percent lanthanum chloride (run 10 ) with a recovery of $48.1 \%$. The 10-stage extractor and the 10-stage stripper are connected in a series to make twenty stages, while the 0.5 molar HDEHP is introduced into the first mixing stage and the 0.1 molar $\mathrm{HCl}$ scrub solution enters the twentieth mixing stage. A 97.0 mol percent lanthanum chloride is produced (run 15) with an impurity concentration of $1.0 \mathrm{~mol}$ percent praseodymium chloride and $2.2 \mathrm{~mol}$ percent cerium chloride. This series of experiments showed that decreasing the rare-earth chloride flow rate and increasing the $\mathrm{HCl}$ flow rate results in a higher purity lanthanum chloride concentration.

The separation and concentration of lanthanum chloride as a raffinate product from mixed rare-earth feed is an excellent illustration of the complexity of obtaining a high-purity rareearth product. A $97 \mathrm{~mol}$ percent lanthanum chloride is marketable. However, the 
lanthanum recovery is only around $59.8 \%$. In order to increase the recovery of lanthanum chloride to the high nineties, the number of stages required for the extraction circuit will have to be increased appreciably. The feed solution contains about $30 \mathrm{~mol}$ percent neodymium chloride, 3.7 mol percent samarium chloride, 8.8 mol percent praseodymium chloride, $10.9 \mathrm{~mol}$ percent cerium chloride, and $2.3 \mathrm{~mol}$ percent gadolinium chloride in addition to the $45.2 \mathrm{~mol}$ percent lanthanum chloride. To extract neodymium chloride from the extract (organic) phase of the lanthanum chloride circuit at a recovery of over $90 \%$ will require installation of a neodymium chloride extraction circuit with a certain number of stages to produce a specified marketable product. A circuit will have to be installed for each of the chlorides (samarium, praseodymium, cerium, and gadolinium) in order to produce the respective high-purity rare earths.

Lanthanum chloride raffinate (aqueous phase) product is reacted with oxalic acid to form the lanthanum oxalate precipitate. The filtered lanthanum oxalate precipitate is then dried at around $300^{\circ} \mathrm{F}$ from 4 to 6 hours. The lanthanum oxalate is then calcined in a furnace at around $800^{\circ} \mathrm{F}$ to form high-purity lanthanum oxide. The other rare earths present in the extract (organic phase) product from the lanthanum separation circuit are stripped with 4 molar $\mathrm{HCl}$ to recover the solvent phase free of rare earths for recycling to the extraction stage. The concentrated rare earths now present in the aqueous phase will be the feed solution to the neodymium extraction circuit. The neodymium extract product is then stripped with 4 molar $\mathrm{HCl}$. The concentrated neodymium aqueous phase is reacted with oxalic acid to form neodymium oxalate which is then dried and calcined to form the neodymium oxide. The same process scheme is applied to the other rare earths in the feed to produce marketable products.

The formation of a third phase or a white precipitate has been reported in the literature when HDEHP is used as the complexing reagent in the separation of rare earths (Harada and Smutz 1970; Owens and Smutz 1968; Peppard et al. 1957). Harada, Smutz, and Bautista $(1971,1972)$ reported the conditions under which rare-earth polymers are formed and characterized the yttrium, lanthanum, praseodymium, neodymium, dysprosium, holmium, and ytterbium polymers of HDEHP by chemical and x-ray diffraction technique.

Rare earths form polymers under certain chemical conditions in the mixer-settler when HDEHP is used. Polymerization in the mixer-settler produces a rare-earth polymer of very high molecular weight. This third phase greatly decreases efficiency of separation in the mixer-settler and also decreases availability of extractable rare earth in solution. The dispersion prevents efficient transfer of the desired rare earth from the aqueous phase to the organic phase. Even a very thin film between the organic-aqueous interface acts as a resistance to mass transfer of rare earth from the aqueous phase to the organic phase. As a result, purity and recovery of the product is lower.

The mixer-settlers are reactors in which organic and aqueous phases are intimately mixed to promote mass transfer of the rare-earth complex from the raffinate (aqueous) phase into the extract (organic) phase. Residence time in the mixer is usually sufficient for the two phases to approach equilibrium. The interdispersed phase is then channeled to the settler segment of the unit where the organic phase is separated from the aqueous phase. The pump-mix mixer-settler has a pumping impeller to provide the driving force for flow of the solutions and interdispersion of the two phases. The throughput of the settler in a pump-mix unit depends primarily on the interphase area. The mixer-settler units are connected in a 
countercurrent cascade arrangement to provide the required number of stages. Each mixersettler unit is a stage.

The engineering company building a chemical separation plant usually has the final decision as to design and configuration of the mixer-settler unit. Additional information on available extractors is found in the review by Hanson (1984) on equipment selection and design, in the paper by Chapman (1984) on metal mass transfer and design, and in the discussion of composition control of extractors by Burkhart (1984).

Separation, concentration, and purification of rare earths from raw material to oxide forms can only be characterized as a modern chemical plant. It requires a good understanding of their extraction chemistry and the chemical engineering fundamentals of multistage processing. Very sophisticated on-line analytical techniques are required for each rare-earth liquid-liquid extraction circuit to support extensive chemical process control for the mixersettler multistage operation. This level of sophisticated chemical plant operation is absolutely necessary if high-purity, value-added rare-earth products are to be produced continuously and reliably at the lowest costs. Design of the plant itself must be flexible in order to accommodate the rapidly changing market demand for any rare-earth element and to be able to use different ore feed material of varying compositions. Additionally, higher level training and experience for plant operators and enhanced technical capabilities of supervisors are a must.

Investment Issues. The many issues an investor group must consider from the outset when deciding the question of developing a proven rare-earth deposit should include the type of commodity to be produced from the ore. Will the marketable products be as mined ore, beneficiated concentrated ore, chemically upgraded ore concentrates, chemically separated rare-earth mixtures, or chemically separated rare-earth oxides with acceptable concentrations or high-purity designations for use in high-technology applications? Depending on the capital resources available to the investor group, the answer will be one or more of the above categories. The rate of return and risk acceptable to the investor group will determine the answer to these questions.

\section{References}

Apgar, H., and P. Poirier. 1976. Separation of high purity RE on a commercial scale. Preprint of paper presented at the 12th Rare Earth Research Conference, Vail, Colorado, 1976.

Aplan, F.F. 1988. The processing of rare earth minerals. Pages 15-34 in R.G. Bautista, and M.M. Wong, eds. Rare earths, extraction preparation and applications. TMS, Warrendale, PA.

Barghusen, Jr., J.J., and M. Smutz. 1957. USAEC ISC-947. Ames Laboratory, Iowa State University, Ames, IA. 105 pp. 
Baroch, C.J., M. Smutz, and E.H. Olson. 1959. Processing California bastnaesite ore. Mining Engineering. 11(3):315-319.

Battista, C., C. Mize, and M. Smutz. 1966. Separation factors for Sm-Nd-D2HPA-H*-H $\mathrm{H}_{2} \mathrm{O}$ chloride and nitrate systems. Journal of Inorganic Nuclear Chemistry. 28:1121-1122.

Bearse, A.E., et al. 1954. Thorium and rare earths from monazite. Chemical Engineering Progress. 50(5):235-230.

Burkhart, L.E. Composition control of extractors. Pages 515-268 in R.G. Bautista, ed. Hydrometallurgical process fundamentals. NATO Conference Series 6. Materials Science, Vol. 10. Plenum Press, New York.

Casto, M.G., M. Smutz, and R.G. Bautista. 1971. Separation of lanthanum from a rare earth chloride mixture using a multistage mixer-settler. Transactions of Society of Mining Engineers. 250:249-251.

Chapman, T.W. 1984. Solvent extraction of metals-metal transfer rates and contractor design. Pages 473-498 in R.G. Bautista, ed. Hydrometallurgical process fundamentals. NATO Conference Series 6. Materials Science, Vol. 10. Plenum Press, New York,

Dayton, S.H. 1956. How MCA floats rare earths in heated circuit. Mining World. $18(1): 43-45$.

Fidelis, I. 1970. Temperature effect on the extraction of lanthanides in the TBP-HNO system. Journal of Inorganic Nuclear Chemistry. 32:997-1003.

. 1971. Influence of temperature on the extraction of lanthanides in the HDEHPHNO System. Pages 1004-1007 in Proceedings of International Solvent Extraction Conference (ISEC 71), Society of Chemical Industry, London. Vol. 2.

Goto, T. 1968. Separation factor for the extraction systems, $\mathrm{YCl}_{3}-\mathrm{ErCl}_{3}-\mathrm{HCl}, \mathrm{YCl}_{3}-\mathrm{HoCl}_{3}-$ $\mathrm{HCl}$ and some lanthanide chlorides-hydrochloric acid with $1 \mathrm{M}$ di-2-ethylhexyl phosphoric acid in n-heptane. Journal of Inorganic Nuclear Chemistry. 30:33053315.

Goto, T., and M. Smutz, 1965a. Equilibria of the systems, $\mathrm{PrCl}_{3}-\mathrm{HCl}, \mathrm{NdCl}_{3}-\mathrm{HCl}$ and $\mathrm{PrCl}_{3}-\mathrm{NdCl}_{3}-\mathrm{HCl}$ with di-2-ethylhexyl phosphoric acid in AMSCO 125-82. Journal of Nuclear Science Technology. 2:410-415.

- 1965b. Separation factors for solvent extraction processes, the system of $1 \mathrm{M}$ di-2ethylhexyl phosphoric acid in AMSCO 125-82; Pr-Nd salts as an example. Journal of Inorganic Nuclear Chemistry. 27:1369-1379. 
Gray, J.A., and M. Smutz. 1966. An equilibrium study of the chloride and nitrate systems of praseodymium and neodymium with tributyl phosphate and acid. Journal of Inorganic Nuclear Chemistry. 28:2015-2024.

Hanson, C. 1984. Equipment selection and design for metals solvent extraction. Pages 499 514 in R.G. Bautista, ed. Hydrometallurgical process fundamentals. NATO Conference Series 6. Materials Science, Vol. 10. Plenum Press, New York.

Harada, T., and M. Smutz. 1970. Extraction of yttrium in the system $\mathrm{YCl}_{3}-\mathrm{HCl}-\mathrm{H}_{2} \mathrm{O}$ di-2ethylhexyl phosphoric acid. Journal of Inorganic Nuclear Chemistry. 32:649-662.

Harada, T., M. Smutz, and R.G. Bautista. 1971. Polymers of iron and rare earths and di-2ethylhexyl phosphoric acid. Pages 950-956 in Proceedings of International Solvent Extraction Conference, (ISEC 71), Society of Chemical Industry, London. Vol. 2.

- 1972. Characterization of iron and rare earth polymers of di-2-ethylhexyl phosphoric acid. Journal of Chemical Engineering Data. 17:203-204.

Harrah, H.W. 1967. Rare earth concentration at Molybdenum Corporation of America. Solvent extraction plant, Part Two. Denver Equipment Company. Deco Trefoil Bulletin M4-B167.

Hoh, Y.C., and R.G. Bautista. 1979a. Liquid-liquid extraction model for the system $\mathrm{LaCl}_{3}-$ $\mathrm{Nd}\left(\mathrm{NO}_{3}\right)_{3}-\mathrm{HNO}_{3}-\mathrm{H}_{2} \mathrm{O}-\mathrm{HDEHP}$-AMSCO. Journal of Inorganic Nuclear Chemistry. 41:1787-1792.

- 1979b. Liquid-liquid extraction equilibrium models for binary and ternary lanthanides - HDEHP systems. I \& EC Process Design \& Development. 18:446453.

Ioannou, T.K., M. Smutz, and R.G. Bautista. 1972. Single and multicomponent equilibrium data for the extraction of $\mathrm{SmCl}_{3}, \mathrm{NdCl}_{3}$, and $\mathrm{CeCl}_{3}$ in acidic chloride solutions with di-2-ethylhexyl phosphoric acid. Metallurgical Transactions. 3:2639-2648.

Johnson, N.L. 1966. Rare earth concentration at Molybdenum Corporation of America. Denver Equipment Company. Deco Trefoil Bulletin M4-B128.

Kaczmarek, J. 1980. Rare earths: discovery and commercial separations. Preprint of paper presented to the American Chemical Society Meeting, August 26, 1980.

Kilbourn, B.J. 1989. The asterisk elements, a.k.a. the lanthanides and yttrium. Pages 447459 in E.E. Torma, and I.H. Gundiler, eds. Precious and rare metal technologies. Elsevier, New York.

Krumholz, P., et al. 1958. Brazilian practice in the separation of rare earths. Pages 184-195 in Proceedings of the Second United Nation International Conference on the Peaceful Uses of Atomic Energy, United Nations, Geneva. Vol. 28. Basic chemistry in nuclear energy. 
Labine, R.A. 1959. Mass production of pure rare earths. Chemical Engineering. July 27:104-107.

Lenz, T.G., and M. Smutz. 1968. The extraction of neodymium and samarium by di-2ethylhexyl phosphoric acid from aqueous chloride, perchlorate and nitrate Systems. Journal of Inorganic Nuclear Chemistry. 30:621-637.

Michelsen, O.B., and M. Smutz. 1971. Separation of yttrium, holmium, and erbium with di-2-ethylhexyl phosphoric acid in chloride and nitrate systems. Journal of Inorganic Nuclear Chemistry. 33:265-278.

Owens, T.C., and M. Smutz. 1968. Extraction of some heavier lanthanides in acidic chloride solutions by di-2-ethylhexyl phosphoric acid. Journal of Inorganic Nuclear Chemistry. 30:1617-1633.

Peppard, D.F., and G.W. Mason. 1963. Some mechanisms of extraction of M(II), (III), (IV), and (VI) metals by acidic organophosphorus extractants. Nuclear Science Engineer. 16:382-388.

Peppard, D.F., et al. 1953. Studies of the solvent extraction behavior of the transition elements. I. Order and degree of fractionation of the trivalent rare earths. Journal of Physical Chemistry. 57:294-301.

. 1957. Fractional extraction of the lanthanides as their di-alkyl orthophosphates. Journal of Inorganic Nuclear Chemistry. 4:334-343.

Pierce, T.B., and P.F. Peck. 1963. The extraction of the lanthanide elements from perchloric acid by di-2-ethylhexyl hydrogen phosphate. Analyst. 88:217-221.

Powell, J.E., and F.H. Spedding. 1959a. Basic principles involved in the macroseparation of adjacent rare earths from each other by means of ion exchange. Chemical Engineering Progress Symposium Series 24. 55:101-113.

. 1959b. The separation of rare earths by ion exchange. Transactions of the Metallurgical Society. 215:457-463.

Thomas, N.E., and L.E. Burkhart. 1974. Distribution coefficient correlations for predicting the extraction equilibria of lutetium-ytterbium and lutetium-thulium binary rare earth mixtures between di-2-ethylhexyl phosphoric acid in AMSCO and aqueous hydrochloric acid solutions. I \& EC Fundamentals. 13:366-372.

Thomas, N.E., M. Smutz, and L. Burkhart. 1971. Separation of thulium and ytterbium in acidic chloride solutions by fractional solvent extraction. I \& EC Fundamentals. 10:453-458.

Treybal, R.E. 1963. Liquid extraction. 2nd ed. McGraw-Hill. 


\title{
Land-Use Planning and Permitting
}

\author{
Mr. Gerald Gallagher \\ Division of Mining \\ Alaska Department of Natural Resources
}

There are three basic categories of land in Alaska: state, federal, and private. Alaska owns about 100 million acres of land with $92 \%$ available for mineral exploration. The federal government is the major landowner in Alaska with about 200 million acres. Unfortunately, since much of it is tied up in one or more restrictive categories, less than $50 \%$ of federal land is available for mineral exploration. Most private land is Native corporation land which totals about 44 million acres. As private land, it is available for mineral exploration requiring a business deal with the private landowner. Rare-earth minerals are easily located; you can stake a mining claim with assurance of rare earths being present.

Clearly, the rare-earth market is primarily an international market. Ownership of mining claims, under both federal and state law, has some restrictions related to foreign ownership. U.S. citizens or companies can own mining claims; foreign corporations can own mining claims only if the country of their origin has reciprocal rights extended to the United States. Alaska has such a statute, and I am considering proposing in January that Alaska's mining law be modified so that restriction is lifted.

Permitting is a complex procedure that is not restricted to Alaska. There are three things a mining company or an individual needs for successful permitting: time, money, and a good attorney. I am not being flip when I say that; it is really quite true. Three years is not an unrealistic requirement to permit a major mine. As noted by the previous speakers, beneficiation, milling, and extraction technology is such that the mines we require will need participation of one of the major corporations such as Molycorp. For such major economic development, three years to work through the permit process is not unrealistic, assuming lengthy litigation is not involved.

You can generally assume that for any mine there are three major permits: land use, wastewater discharge, and fisheries or habitat. Land-use permits for state land come from Alaska Department of Natural Resources (DNR), Division of Land \& Water Management. If it is federal land, the U.S. Bureau of Land Management (BLM) issues land-use permits. You don't need a land-use permit for Native land, but you will need to negotiate a deal with the Native corporation. Secondly, the water or wastewater discharge permit will be processed either through the Alaska Department of Environmental Conservation (ADEC), the federal Environmental Protection Agency (EPA), or both. Thirdly, a fisheries/habitat permit will be required by either a state or federal agency. In related issues, an environmental impact statement (EIS) can be anticipated for any major activity. This is a federal requirement rather than a state requirement, but every major commercial development is going to have some federal permit. It may be required to also have a National Pollutant Discharge Elimination System (NPDES) permit for wastewater discharge (in addition to the ADEC permit) and a clear air permit as well. So it is reasonable to also anticipate an EIS. These multiple permits take quite a bit of time to prepare and obtain; three years is a reasonable preparation time. 
Another related issue, which is probably the most difficult and contentious in Alaska, is transportation. Any time you build a new road in Alaska, people get excited. You are opening wilderness which is not congressionally mandated. A road to a mine is going to cross fish streams and wildlife habitat, and it is going to cross wetlands. Those transgressions will generate a series of permits.

The last related issue which is particularly important for rare-earth mining business is the federal Resource Conservation and Recovery Act (RCRA). The mining industry until now has not dealt with RCRA, but that will soon end. The EPA now has a proposal to manage mining waste under RCRA using a portion of RCRA Subtitle D to manage high-volume, low-toxicity waste. This will include overburden and tailings as well as the beneficiation waste discussed today. This will be a nationally mandated form of reclamation that will include long-term monitoring for decades. The American Mining Congress has made a counterproposal to EPA for long-term monitoring and liability of 30 years. This includes closure, maintenance of surface waters and ground waters, and air quality. We have not seen much long-term monitoring in Alaska yet, but it is going to be particularly important for any mining process with complex beneficiation schemes. Obviously, the easiest way to mine would be to extract the ore, impose no beneficiation or no upgrading, and ship it off the mine site in containers. It is not economical, however, to ship out of Alaska, so I think RCRA is something that is going to be particularly important to all of the hard-rock industry, and probably very applicable to the rare-earth industry.

I want to stress the individual nature of preparing and obtaining the permits necessary for mining rare-earths. It will take time änd money, and may not be easy, but it is certainly not impossible. 


\title{
Rare Earths in Alaska
}

\section{Day Two: Call to Order}

\begin{abstract}
Dr. Henry Cole:
We had a terrific session Day One, a huge amount of information which will be briefly summarized before we form discussion sessions. Dr. Bautista, Dr, Kilbourn, and Jim Barker will present synopses of beneficiation, basic uses of rare earths, and Alaska resource opportunities.
\end{abstract}

Yesterday the information flow was from our visitors and experts from Outside. Today, the moderators of the various sessions are Alaskans aware of the Alaska "slant" to each of these areas. Hopefully, we can combine the expert knowledge with Alaska needs, developing a better understanding of the problems and opportunities and suggesting recommendations.

Dr. Bob Hoekzema, U.S. Bureau of Mines, will be moderating a session on survey and exploration needs. Dr. Don Cook of the Mineral Industry Research Laboratory (MIRL) of the University of Alaska Fairbanks (UAF) will lead the session on extraction refining methods and beneficiation methods. The third session, environmental issues, will be led by Dr. Paul Reichardt, Department of Chemistry at UAF, Recommendations from these sessions will be presented afterward to the entire group.

A crucial area of interest is Pacific Rim trade and marketing. Bob Poe, Director of the Office of International Trade in the Office of Governor Steve Cowper, will moderate that session. Dr. Marvin Andresen, Professor of Business Administration at UAF, will moderate another session on the general topic of manufacturing in Alaska, an area of possible potential that we wish to explore. These two sessions are naturally associated with one another.

So, first we have the technical summaries ${ }^{4}$, after which we split into sessions. I would request the visitors from Molycorp, Mitsubishi, or MITI, to distribute themselves somewhat equally among the two marketing and manufacturing groups; we would like the benefit of your knowledge and your commentary equally in these two areas.

\footnotetext{
'At this time the presenters from the first day (Dr. Kilbourn, Jim Barker, and Dr. Bautista) each presented a short summary of their technical information. That discussion need not be restated for this symposium.
} 


\section{Break Out Sessions}

\section{Dr. Cole:}

The moderators who have been convening the Day Two discussion sessions will present their group's recommendations about business, economic developments, environmental issues, and beneficiation. We will then have a final commentary from our invited guests.

\section{Session Recommendations}

\section{Dr. Hoekzema:}

Our session discussed exploration. We proceeded by addressing several questions:

1. What do we have in terms of resources? Jim Barker and others addressed that quite well.

2. Where are the data gaps in our current information?

3. How can we encourage industry to explore those deposits in Alaska?

4. Do we need to find more deposits? I think the answer is a qualified yes.

Alaskans in general believe we need to know as much as possible about Alaska's resources for a variety of reasons. Because there is competition from substantial worldwide rare-earth resources, Alaskans need to carefully consider what we really want to develop. We have some fairly specific recommendations on delineating the resources, things that the state, universities, and federal government could do, and who should be involved in this exploration and delineation. We also began to discuss how this activity should be done, but our hour was almost finished. Let me list the recommendations, with session members free to add remarks and keep me honest.

Recommendation \#1: We need to maximize our advantages and minimize our disadvantages. As advantages, we have a tremendous land base and tremendous mineral resources. We need to minimize some of the disadvantages on the other side.

Recommendation \#2: The state needs to support further exploration of mineral resources; we need to promote additional exploration of all of our mineral resources, including rare earths. We need to develop a comprehensive mineral inventory, and the state geologist has some very good cost figures for this. For the White Mountain study recently done jointly by the state of Alaska, U.S. Geological Survey, and Bureau of Mines, the survey cost per acre was about $\$ 2.50$ to $\$ 4.50$. Bruce Geraghty perhaps best made the point that if we don't have adequate information, there is a good chance we will lose access to even larger portions of our land in Alaska. We need good minerals information in order to make good land decisions in the future.

Recommendation \#3: It is critical that state efforts be integrated with federal efforts. From a federal perspective, the federal government currently has a tremendous interest in providing matching funds on any kind of project. If the state is willing to match these funds, that will more than likely ensure the project being completed. 
Recommendation \#4: All available data should be evaluated, particularly the excellent National Uranium Resource Evaluation (NURE) data. There are 70,000 data points contained in NURE that have information for 39 elements of which several are rare-earth elements. It is questionable as to who may take a lead in this for the state. The University of Alaska (UA) could possibly work in conjunction with Los Alamos or another facility. Distributing solid data on Alaska deposits would entice industry to come to Alaska to consider the deposits. This data would contain total mineral characterization including tonnage, grade, and identification of the contained rare-earth elements. We probably should also include beneficiation processing and recovery and anticipated problems. We want to develop an Alaska rare-earth deposit such as Bokan Mountain fairly soon.

Recommendation \#5: In discussing the University of Alaska's role in exploration, we recommend that it be responsible for training and providing experienced, knowledgeable individuals. Jim Barker made the strong point that there are very few people with expertise in rare earths, particularly in Alaska. The amount of training involved in getting someone into the field is great; we must respond to this need now. Besides the educational role, UA should get involved in site-specific investigation, possibly in conjunction with state agencies. The other role for UA in exploration is developing the capability to analyze existing data samples and run survey projects.

Another very strong recommendation came out of this morning's session; the state should advocate use of most of Alaska's lands and take a strong advocacy role toward multiple use, not just of state lands but also of federal lands. For example, one specific deposit mentioned was Roy Creek and the White Mountain area. If the state took a strong advocacy role in BLM developing a land management plan, that would encourage development of the White Mountain deposit.

Any studies of rare earths in Alaska should be done with the ultimate consumer in mind. One of these consumers, obviously, would be industry. We need to inform industry of any developments from exploration efforts in Alaska as soon as possible and encourage their participation.

\section{Dr. Don Cook:}

I think a lot of our recommendations probably repeat those of other sessions.

Recommendation \#1: The state does not have enough information to interest private industry; I think it is an obligation of the state to obtain some of that information. But it was also agreed that there is a limit as to how far the state should investigate, bearing in mind that extracting rare earths in a high purity state and manufacturing the products is highly dependent upon market opportunity which is changeable.

The first thing we need is mineral characterization. Each specific location may have a different suite of minerals, and mineral characterization would include processing needs and marketplace value. Another major effort should be made in the extractive processes. Mineral beneficiation, the concentration of mineral commodities as opposed to concentration of elements, raises the question of how far downstream we extend the extraction processes. 
We should investigate what could be produced in mixed metals, what possibly could be done with the light rare earths, and what should be done with the heavy rare earths. We probably should not investigate the problems and opportunities related to the high-purity products; that is a trickier business decision and could radically change by the time you got information.

How does the state supply this information to a potential industrial organization? It is logical that it be done at the University of Alaska, probably the only organization that might have the necessary facilities. Mineral Industries Research Laboratories (MIRL) has the facilities for mineral characterization and analysis and the capability of doing test runs on mineral beneficiation to some degree. But that really only represents a beginning and requires more serious effort before we obtain adequate information to be of realistic assistance to industry in Alaska at any particular location. Industry is not going to tackle anything unless they have basic and useful preliminary data.

\section{Dr. Paul Reichardt:}

I chaired the session on environmental concerns. We started with two assumptions, 1) that Alaska already has the experience dealing with routine aspects of development, construction of new roads, docks, and so forth, and 2) that we are talking about no specific sites. So our focus was on the industry rather than ơn a particular development. Out of our session came five recommendations.

Recommendation \#1: In the area of education and research we were concerned with three things. First, we need to develop baseline data on toxicity and radioactivity of sites. This would be information needed both by potential developers and concerned citizens if development was contemplated. Second, we need techniques and strategies for keeping nuclear waste at a level where it would be regulated as low-level radioactive waste instead of high-level radioactive waste. Third, a program is needed to inform citizens of Alaska of the environmental realities of these operations and as well as the existence of environmental safeguards either already in place or required for an operation of this kind.

Recommendation \#2: We recommend that the state make a firm, clear commitment to a state-of-the-art processing facility with zero discharge into the environment. That is the way modern processing facilities for rare earths operate elsewhere around the world, and we should state clearly at the onset that Alaska would settle for no less. It would also greatly simplify a lot of facility planning because many of the environmental problems are already eliminated in the existing state-of-the-art facility.

Recommendation \#3: The third recommendation, not an environmental concern in itself, comes from past environmental concerns. We must clearly define the land availability status of each potential site so that we avoid disruptive land status disagreements at critical points of investment and development. We want land use and availability defined and agreed to by all parties for all potential sites. 
Recommendation \#4: We must clearly define reclamation requirements. For example, revegetation, normally a reclamation requirement, is so ill-defined that it often becomes a later issue of contention. Reclamation needs to be defined at the outset.

Recommendation \#5: We recommend that the state explore the establishment of an approved waste disposal site within Alaska. If one existed within the state, that would certainly be a big plus for any potential development in rare earths. I think it would extend well beyond rare earths in solving environmental problems and attracting other potential industries.

\section{Dr. Marvin Andreson:}

I am reporting both on Pacific Rim trade aspects and on manufacturing in Alaska. I condensed our extensive notes into three categories: problems, opportunities, and recommendations.

The first problem recognized was the relatively small quantity of rare earths that are needed worldwide, approximately 50,000 tons of concentrate per year. As technology is improved, even smaller quantities are needed of particular elements. A side benefit to that is that as technology improves, markets increase their need for rare earths. The second problem is the general necessity of extraction all of the rare earths as a mixed group while the market may only really need a small selection from the group. The chemical process for separating rare earths is very complicated and, as stated before, there is really little knowledge of Alaska's deposits. We really are at the very beginning.

The number one opportunity our group recognized is the chance to process rare earths as by-products of other activities such as existing placer operations. Even with small quantities needed, some companies explore directly for rare earths. Japan's market, as a major purchaser of rare earths, is strongly controlled by China which will continue to be a major source. But Japan would like to geographically diversify its market sources, so perhaps Alaska could fill a niche there. Also, existing placer deposits in Alaska may allow for a quick sampling survey, possibly indicating some deposits that are readily available from placer operations and could be marketed in a semiconcentrated form.

Finally, the broad recommendation of our group is to develop a very strong, creative, favorable economic climate. To support this climate, more studies are needed for increased awareness of rare earths in Alaska. A second recommendation is to increase understanding of the technology of rare-earth element processing. Alaska, rather than settling for the status of "third-world" ore supplier, should perhaps concentrate on becoming a world leader in developing the technology. Because this whole industry is so small, Alaska could take a leadership role and become the dominant force. Because the quantities are small, perhaps instead of simply mining and exporting our products from Alaska, materials could be transported from other places and processed here.

The final recommendation is to develop a long-term strategy, not just for rare earths, but for all minerals. Return on investment takes a long, long time, so this industry probably is not just a private sector activity. 


\section{Final Summary and Close}

\section{Dr. Henry Cole:}

As many of you know, the state, and the governor in particular, have been wrestling with the general economic problems of Alaska. This meeting was convened to explore some other areas that might have potential for economic development. There are general rules of strategy in any of the models discussed for state or federal government implementation of economic development through the use of technology.

First, it does not matter what the product is, whether it is minerals, timber, fisheries, some manufactured object, the lack of infrastructure in Alaska is a major problem. By infrastructure I mean communication and transportation and the effective, ongoing coordination between academic, private, financial, and regulatory sectors in pursuit of common development goals. This deficiency is constant.

We need not look far into our history of development to see why this situation exists. The huge oil fields, our largest economic development, required financial power and expertise readily supplied from Outside by the development companies. For those projects it was not necessary for Alaska to worry about its own few resources and lack of infrastructure. It was not necessary for us to contribute much when it was all easily created from Outside. Business organized a visiting expeditionary force, then oil companies pumped the oil, built the pipeline, and disappeared. The state has experienced pulses of economic development with each wave of economic opportunity setting a new resource in place, and then leaving the state. Only some residue of technical skill and an operations base remain.

But as somebody pointed out earlier today, the University of Alaska missed a real opportunity to provide necessary training programs for Prudhoe Bay operations. I never met anyone at Prudhoe Bay who trained at UAF. There are significant training programs from Anchorage up to Prudhoe Bay. Fairbanks, however, has not responded in that way, so the need for training on a state level, and assisting and working with the University in the general training of personnel is a situation of great severity.

Only within the last two weeks, two of the best geologists I know have left the state, a trend we have to reverse. One way we can reverse it is to create a critical mass of experts to address certain problems when needed. We have done this at this conference today. To avoid emulating a third-world country, we need to make better contact with other countries and the Lower 48. Our model for development should not be a center of excellence with all personnel located in Alaska, but an interactive consortium model whereby we can create mechanisms of contact and exchange with people of technical skill from the University of Alaska industry programs, the Lower 48 , and overseas.

To see a return on investment, we must be serious about long-term strategy. Any strategy could be overturned in the next administration, a victim of our four-year incremental political life span. We need to set the ground rules to which future administrations will adhere. The University of Alaska has a role, not only in training, but also in development of specific knowledge in the rare earths and beneficiation and extraction techniques, and in vigorous state survey programs including the NURE data. All of these things are absolute preconditions. While we cannot yet predict the markets, such as whether yttrium will be the number one superconductor of all time, we do know that the potential for development for the full suite of rare earths does exist. That is the state's point of view. 
I wish to thank everyone who has taken the time to travel here, our friends from Mitsubishi, MITI, OIT, Anchorage, and the invited speakers and moderators. I think we have had an exceptional mix of people presenting their information and expertise which we will publish as a series of papers. This symposium has worked out exceptionally well. 



\section{Technical Presenters}

Mr. James C. Barker

Supervisory Physical Scientist, U.S. Bureau of Mines

794 University Avenue, Fairbanks, AK 99709

Mr. Barker has worked in the minerals industry in Alaska since 1969 and joined the U.S. Bureau of Mines in 1975. For the last ten years Mr. Barker has been evaluating strategic and critical minerals in Alaska, particularly the rare-earth elements.

Dr. Renato G. Bautista

Professor, Department of Chemical and Metallurgical Engineering

Mackay School of Mines

University of Nevada

Reno, NV 89557-0136

Dr. Bautista was educated at the University of Santo Tomas, Phillipines; MIT; and the University of Wisconsin. He has extensive consulting experience for international industries in metallurgy and electrolytic processes of refining.

Mr. Jeff Burton

Coordinator of the Mining Technology Program

Bering Straits Native Corporation

P.O. Box 1008, Nome, AK 99762

Mr. Burton served as coordinator for the Mining Technology Program from 1985 to 1989. He received a BS and MS in geoscience from the University of Alaska Fairbanks. He has worked in the mineral industry since 1973, and for ten years owned a Fairbanks-based industry consulting business. Mr. Burton is currently employed as Vice President of Land \& Resources, Bering Straits Native Corporation.

Dr. Robert Forbes

Alaska State Geologist and Director, Division of Geological and Geophysical Surveys

Alaska Department of Natural Resources

3700 Airport Way, Fairbanks, AK $99709-4609$

Dr. Forbes is founder of the Solid State Geophysical Program at the Geophysical Institute, University of Alaska Fairbanks, and former chairman and Professor Emeritus of the Geology Department. One of the early pioneers in uranium and rare-earth investigation in the state, this year marks Dr. Forbes' 35th year of field work in Alaska.

Mr. Jerry Gallagher

Director, Division of Mining

Alaska Department of Natural Resources

3601 C Street, Suite 880, Anchorage, AK 99510

Mr. Gallagher received a BS and MS in geology at Kent State University. He has worked as a field geologist for industry in Colorado, California, and since 1974 in Alaska. 
Dr. Karl Gschneidner

Director, Rare-Earth Information Center

Iowa State University

Ames, IA 50011-3020

Dr. Gschneidner received his doctorate at Iowa State University and worked in rare earths at Los Alamos. In 1966 he founded the Rare-Earth Information Center. His specialized areas include solid state properties, heat capacity, phase diagrams, and high-temperature superconducting crystals.

Dr. Masaharu Kamitani

Chief, Mineral Resources Section, Mineral Deposits Department, Geological Survey of Japan

Agency of Industrial Science and Technology

Ministry of International Trade and Industry

1-1-3 Higashi, Tsukuba, Ibaraki 305 Japan

Currently chief of the Mineral Resources Section, Dr. Kamitani has been a geologist with the Ministry of International Trade and Industry for thirty years specializing in rare earths.

Dr. Barry T. Kilbourn

Coordinator for Technical Development

Unocal/Molycorp

709 Westchester Avenue, White Plains, NY 10604

Dr. Kilbourn received his education at Oxford University in England. He researches new uses for lanthanides and yttrium and develops applications for new technology for Unocal/Molycorp, the world's major producer of rare earths. 


\section{Symposium Participants}

David Adams

Fairbanks Exploration

P.O. Box 81598

College, Alaska 99708

Dr. Marvin Andresen

School of Management, Business Admin. Dept.

$120 \mathrm{C}$ Bunnell Bldg.

University of Alaska Fairbanks

Fairbanks, Alaska 99775-0360

Dr. Syun Akasofu

Director, Geophysical Institute

601 Elvey Bldg.

University of Alaska Fairbanks

Fairbanks, Alaska 99775-0800

William Baranauskas

165 Rhubarb Drive

Fairbanks, Alaska 99712-1813

Dr. Raghbir Basi

Alaska Pacific University

4101 University Drive

Anchorage, Alaska 99508

Dr. Peter Biesiot

School of Management, Business Admin. Dept. 120B Bunnell Bidg.

University of Alaska Fairbanks

Fairbanks, Alaska 99775-0360

Dr. Earl Beistline

Alaska Minerals Commission

P.O. Box 80148

Fairbanks, Alaska 99708

DuWayne Bostow

Geophysical Institute

122 Elvey Bldg.

University of Alaska Fairbanks

Fairbanks, Alaska 99775-0800

Victor Buberge

1825 Loose Moose Loop

Fairbanks, Alaska 99705

Roger C. Burggraf

Alaska Miners Association

830 Sheep Creek Road

Fairbanks, Alaska 99709

Dr. Henry Cole

Science Advisor, Office of the Governor

OMB, Pouch A

Juneau, Alaska 99811

Dr. Don Cook

Mining and Geological Engineering Dept.

212A O'Neill Bldg.

University of Alaska Fairbanks

Fairbanks, Alaska 99775-1190
James Deininger

U.S. Bureau of Land Management

1150 University Ave.

Fairbanks, Alaska 99704

Keith Fabing

Tryck, Nyman and Hayes

911 West 8th Avenue

Anchorage, Alaska 99501

Yozo Futamara

Nikko Trading Company

Wako Bussan Co. Ltd., Tokyo

950 Blm Avenue; Suite 330

San Bruno, California 94066

Bruce R. Geraghty

Alaska Senate Resource Committee

P.O. Box Box 55028

North Pole, Alaska 99705

Charles B. Green

Alaska Department of Commerce and Economic Development

1001 Noble Street, Suite 420

Fairbanks, Alaska 99701

Howard Griffith

Yukon Pacific Corporation

900 West 5th Avenue, Suite 730

Anchorage, Alaska 99501

Dr. Daniel B. Hawkins

Department of Geology and Geophysics

304B Brooks Bldg.

University of Alaska Fairbanks

Fairbanks, Alaska 99775-0760

Bob Hoekzema

U.S. Bureau of Mines

201 East 9th Avenue, Suile 101

Anchorage, Alaska 99501

Ronald A. Jaeger

Geotechnica Alaska

P.O. Box 2095

Fairbanks, Alaska 99707

Dr. Masaharu Kamitani

Chief, Mineral Resources Section

Mineral Deposits Department

Geological Survey of Japan

Agency of Industrial Science and Technology

Ministry of International Trade and Industry

1-1-3 Higashi, 'T'sukuba

Ibaraki 305 JAPAN 
Dr. Koji Kawasaki

Geophysical Institute

408B Elvey Bldg.

University of Alaska Fairbanks

Fairbanks, Alaska 99775-0800

Dr. Lawrence Kodosky

Natural Science Department

Oakland Community College

2900 Featherstone Road

Auburn Hills, Michigan 48326

Yashikazu Kojima

Deputy General Manager

New Business Development

Mitsubishi Materials Corporation

1-5-1 Marunouchi

Chiyoda-ku

Tokyo 100 JAPAN

Toshio Kondo

Nissho Iwai American Corporation

2600 Cordova Street, Suite 208

Anchorage, Alaska 99503

Dr. Hsing Kuang Lin

Mineral Industry Research Laboratory

210 O'Neill Building

University of Alaska Fairbanks

Fairbanks, Alaska 99775-1190

John O. Landreth

General Manager for Exploration

Unocal/Molycorp

1201 West 5th Street

Los Angeles, California 90017

Jed Lewis

ON LINE Exploration Services

P.O. Box 82075

Fairbanks, Alaska 99708

Dr. Don Lokken

Chemistry Department

302 Bunnell Building

University of Alaska Fairbanks

Fairbanks, Alaska 99775

Tom Mackay

Neomet

Pittsburg, Pennsylvania

Dr. David R. Maneval

9013 Blue Pool

Columbia, Maryland 21045

Howard Merken

P.O. Box 901404

Fairbanks, Alaska 99775

J.D. Miller

$216 \mathrm{~W}$. C. Browning Building

University of Utah

Salt Lake City, Utah 84112

Harold J. Noyes

Chief Geologist, Doyon Ltd.

201 First Avenue

Fairbanks, Alaska 99701
Dr. Patrick O'Rourke

Chancellor

University of Alaska Fairbanks

Signer's Hall

University of Alaska Fairbanks

Fairbanks, Alaska 99775-0500

Fred Pankratz

P.O. Box 60183

Fairbanks, Alaska 99706

Robert Poe

12035 Wilderness Drive

Ancliorage, Alaska 99506

Dr. Luis Proenza

Vice Chancellor for Research

306 Signer's Hall

University of Alaska Fairbanks

Fairbanks, Alaska 99775-0500

Dr. P.D. Rao

Mineral Industry Research Laboratory 210 O'Neill Building

University of Alaska Fairbanks

Fairbanks, Alaska 99775

Dr. Paul Reichardt

College of Natural Sciences

465 Duckering Bidg.

University of Alaska Fairbanks

Fairbanks, Alaska 99775-1240

Donald Runberg

Bureau of I and Management

1150 University Avenue

Fairbanks, Alaska 99709

Jane Smith

Mineral Industry Research Laboratory

210 O'Neill Building

University of Alaska Fairbanks

Fairbanks, Alaska 99775-1180

Dr. Richard Stolzberg

Department of Chemistry

195 Duckering Bldg.

University of Alaska Fairbanks

Fairbanks, Alaska 99775-0520

Kerwin Tschetter

N.R.G. Company

P.O. Box 81343

Fairbanks, Alaska 99708

Daniel Walsh

Mineral Industry Research Laboratory

210 O'Neill Bldg.

University of Alaska Fairbanks

Fairbanks, Alaska 99775-1180

Dr. Norio Yamamoto

Research Director

Mitsubishi Research Institute

Time Life Building

3-6-2 Otemachi, 2-Chome

Chiyoda-ku

Tokyo 100 JAPAN 